Supporting Information for

Influences of Ligand Backbone Substituents on Phosphine-Carbonyl Palladium and Nickel Catalysts for Ethylene Polymeriza-tion and Copolymerization with Polar Monomers

Ningning Zhu $\dagger^{\mathrm{a}}$, Tao Liang $\dagger^{\mathrm{a}}$, Yongshuang Huang ${ }^{\mathrm{a}}$, Wenmin Pang ${ }^{\mathrm{a}}$, Min Chen*b, Chen Tan*b

${ }^{a}$ Hefei National Laboratory for Physical Sciences at the Microscale, CAS Key Laboratory of Soft

Matter Chemistry, Department of Polymer Science and Engineering, University of Science and

Technology of China, Hefei, 230026, China.

${ }^{b}$ Key Laboratory of Structure and Functional Regulation of Hybrid Materials of Ministry of Education, Institutes of Physical Science and Information Technology, Anhui University, Hefei, Anhui, 230601, China.

$\dagger$ These authors contributed equally to this work.

1. Supporting figures.

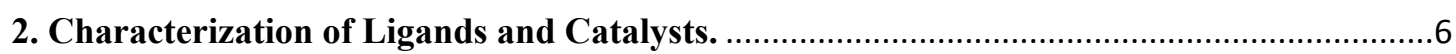

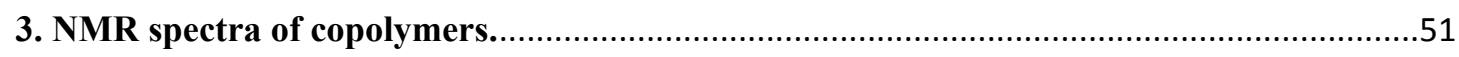

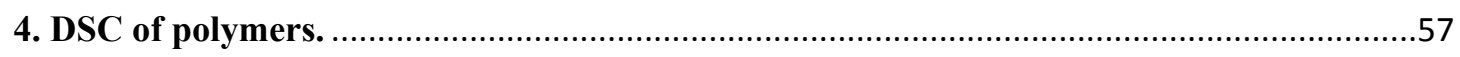

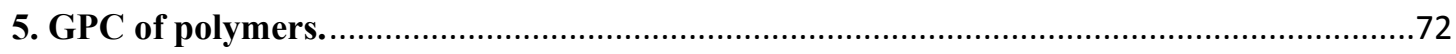

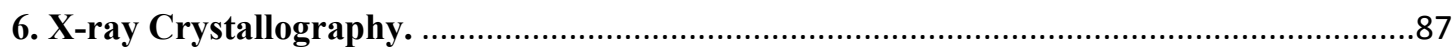




\section{Supporting figures.}

\begin{tabular}{|c|c|c|c|c|c|}
\hline$\%$ V Free & \multicolumn{2}{|c|}{$\%$ V Buried } & & \multicolumn{2}{|c|}{$\%$ V TotVEx } \\
\hline 49.6 & 50.4 & & & 9.9 & \\
\hline Quadrant & $V f$ & $v_{b}$ & $V_{t}$ & $\% V f$ & $\%$ V b \\
\hline sw & 9.7 & 35.2 & 44.9 & 21.5 & 78.5 \\
\hline NW & 20.3 & 24.6 & 44.9 & 45.2 & 54.8 \\
\hline NE & 34.3 & 10.5 & 44.9 & 76.5 & 23.5 \\
\hline SE & 24.7 & 20.1 & 44.9 & 55.1 & 44.9 \\
\hline
\end{tabular}

Steric Map

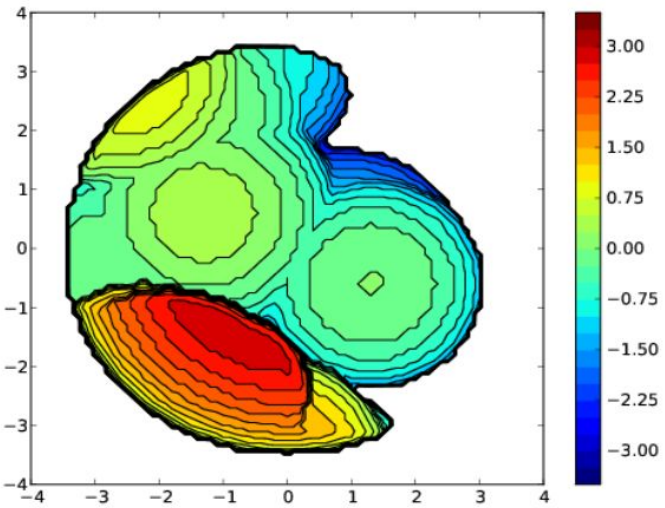

Figure S1. \%Vbur and steric map representation of Pd2.

\begin{tabular}{|lccccc|}
\hline \%V Free & \multicolumn{2}{c}{ \%V Buried } & \multicolumn{3}{c}{$\%$ V TotVEx } \\
\hline 51.2 & 48.8 & \multicolumn{3}{c}{99.9} \\
& & & & & \\
& & & & & \\
\hline Quadrant & Vf & V b & V t & $\%$ V f & $\%$ V b \\
\hline SW & 16.0 & 28.9 & 44.9 & 35.7 & 64.3 \\
\hline NW & 19.1 & 25.8 & 44.9 & 42.5 & 57.5 \\
NE & 34.5 & 10.4 & 44.9 & 76.8 & 23.2 \\
\hline SE & 22.4 & 22.5 & 44.9 & 49.9 & 50.1 \\
\hline
\end{tabular}

Steric Map

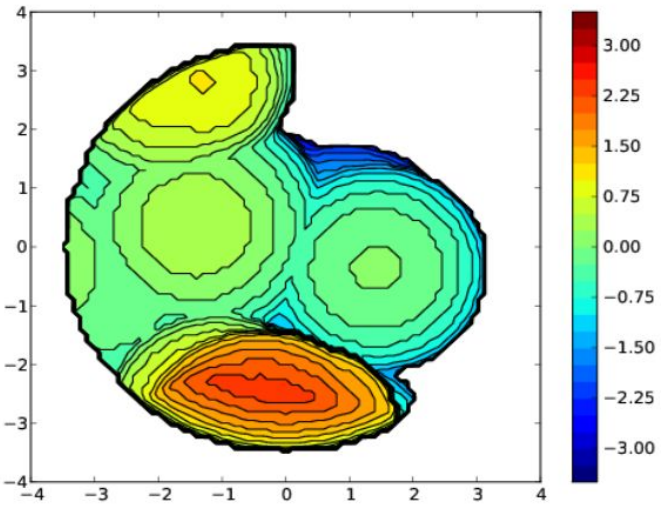

Figure S2. \%Vbur and steric map representation of Pd9. 


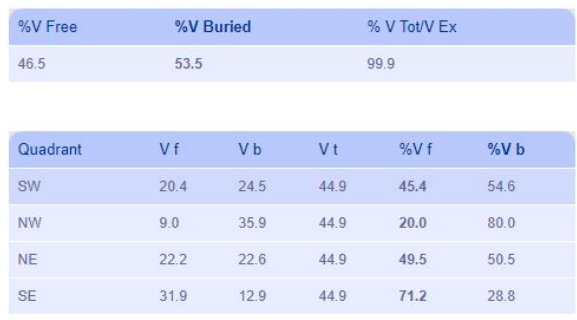

Steric Map

回 $x$ 圆

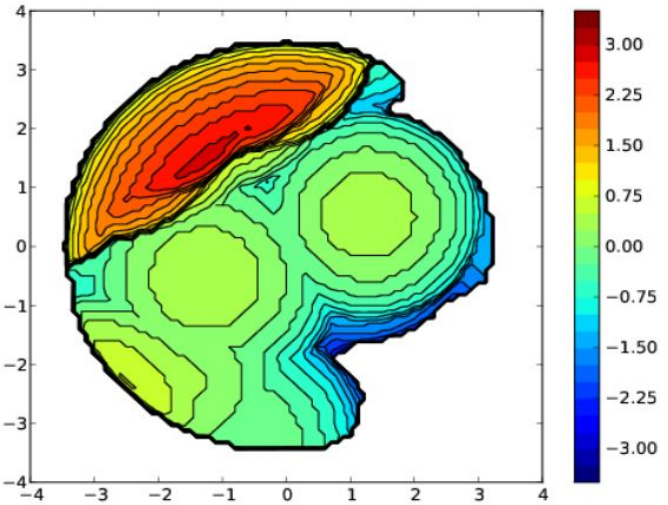

Figure S3. \%Vbur and steric map representation of Ni2.

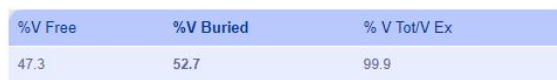

\begin{tabular}{llllll|}
\hline Quadrant & $\mathrm{Vf}$ & $\mathrm{Vb}$ & $\mathrm{Vt}$ & $\% \mathrm{Vf}$ & $\% \mathrm{~V} \mathrm{~b}$ \\
\hline SW & 21.7 & 23.1 & 44.9 & 48.5 & 51.5 \\
NW & 9.6 & 35.2 & 44.9 & 21.5 & 78.5 \\
NE & 21.3 & 23.5 & 44.9 & 47.6 & 52.4 \\
SE & 32.2 & 12.6 & 44.9 & 71.8 & 28.2 \\
& \multicolumn{5}{c}{ Steric Map }
\end{tabular}

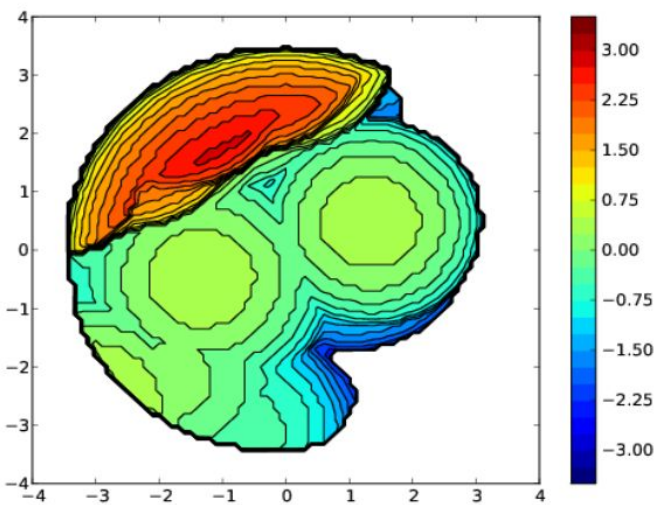

Figure S4. \%Vbur and steric map representation of Ni9. 


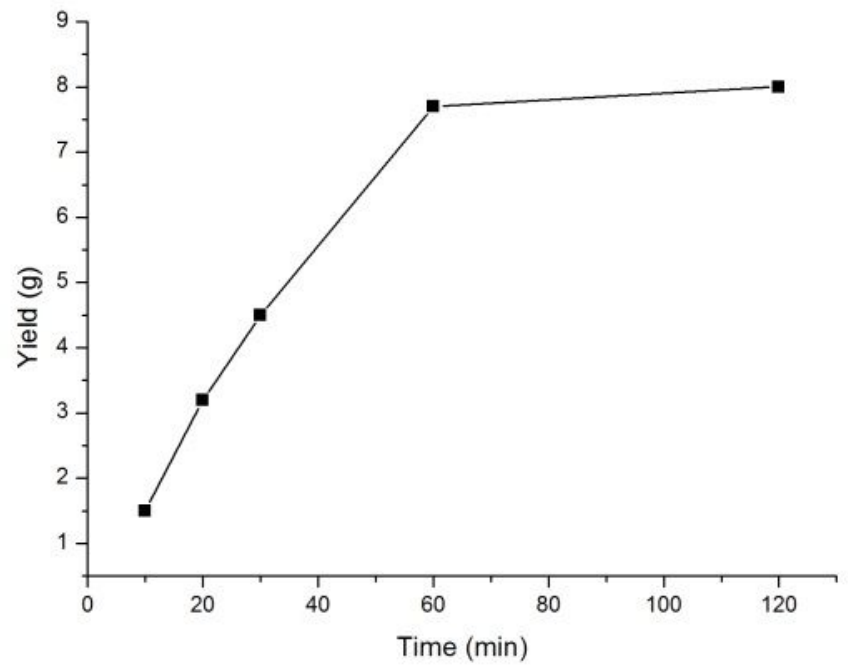

Figure S5. Time dependence studies. Relations between polymer yield and reaction time in ethylene polymerization catalyzed by $\mathbf{P d} 2$ at $80^{\circ} \mathrm{C}(\mathbf{P d} \mathbf{2}$ catalyst $=2 \mu \mathrm{mol}, 1.2 \mathrm{eq} . \mathrm{NaBAF}$, ethylene $=8 \mathrm{~atm}$, toluene $=18 \mathrm{~mL}, \mathrm{CH}_{2} \mathrm{Cl}_{2}=2 \mathrm{~mL}$ ).

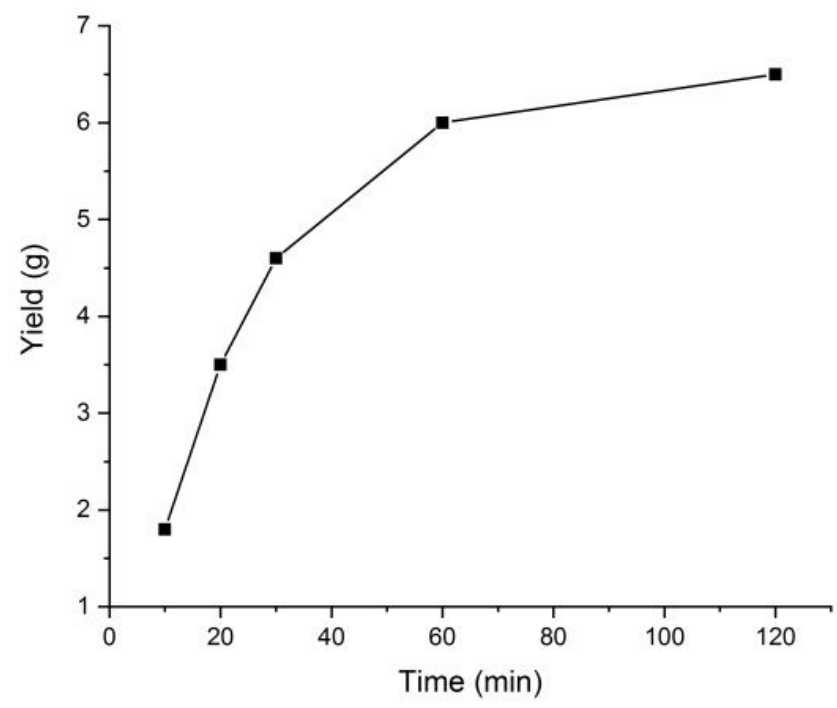

Figure S6. Time dependence studies. Relations between polymer yield and reaction time in ethylene polymerization catalyzed by $\mathbf{N i 2}$ at $80^{\circ} \mathrm{C}(\mathbf{N i 2}$ catalyst $=2 \mu \mathrm{mol}$, ethylene $=8 \mathrm{~atm}$, toluene $=18 \mathrm{~mL}$, $\mathrm{CH}_{2} \mathrm{Cl}_{2}=2 \mathrm{~mL}$ ). 


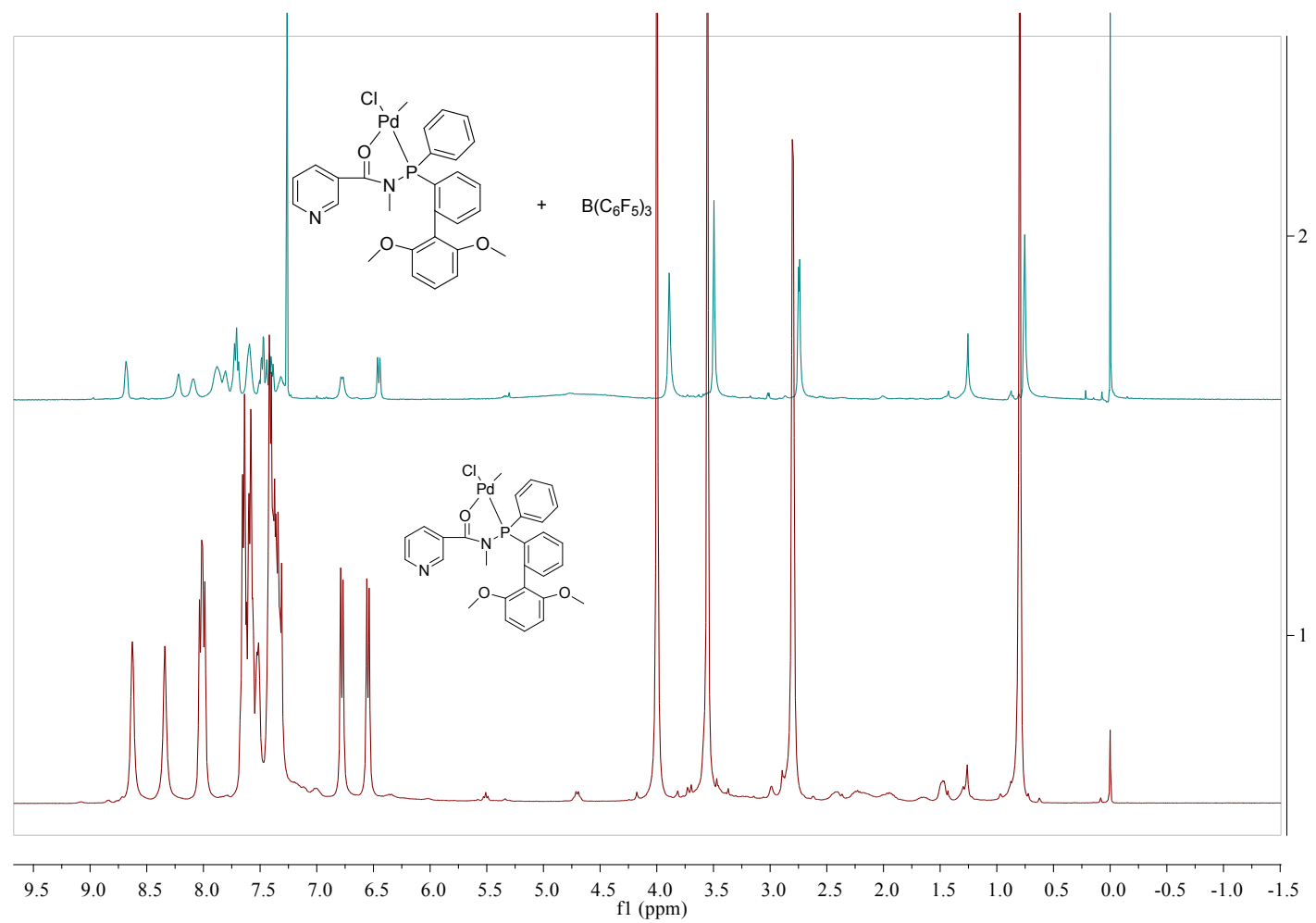

Figure S7. ${ }^{1} \mathrm{H}$ NMR spectrum $\left(400 \mathrm{MHz}, \mathrm{CDCl}_{3}\right)$ of $\mathrm{Pd} 7$ with 1 equivalent of $\mathrm{B}\left(\mathrm{C}_{6} \mathrm{~F}_{5}\right)_{3}$.
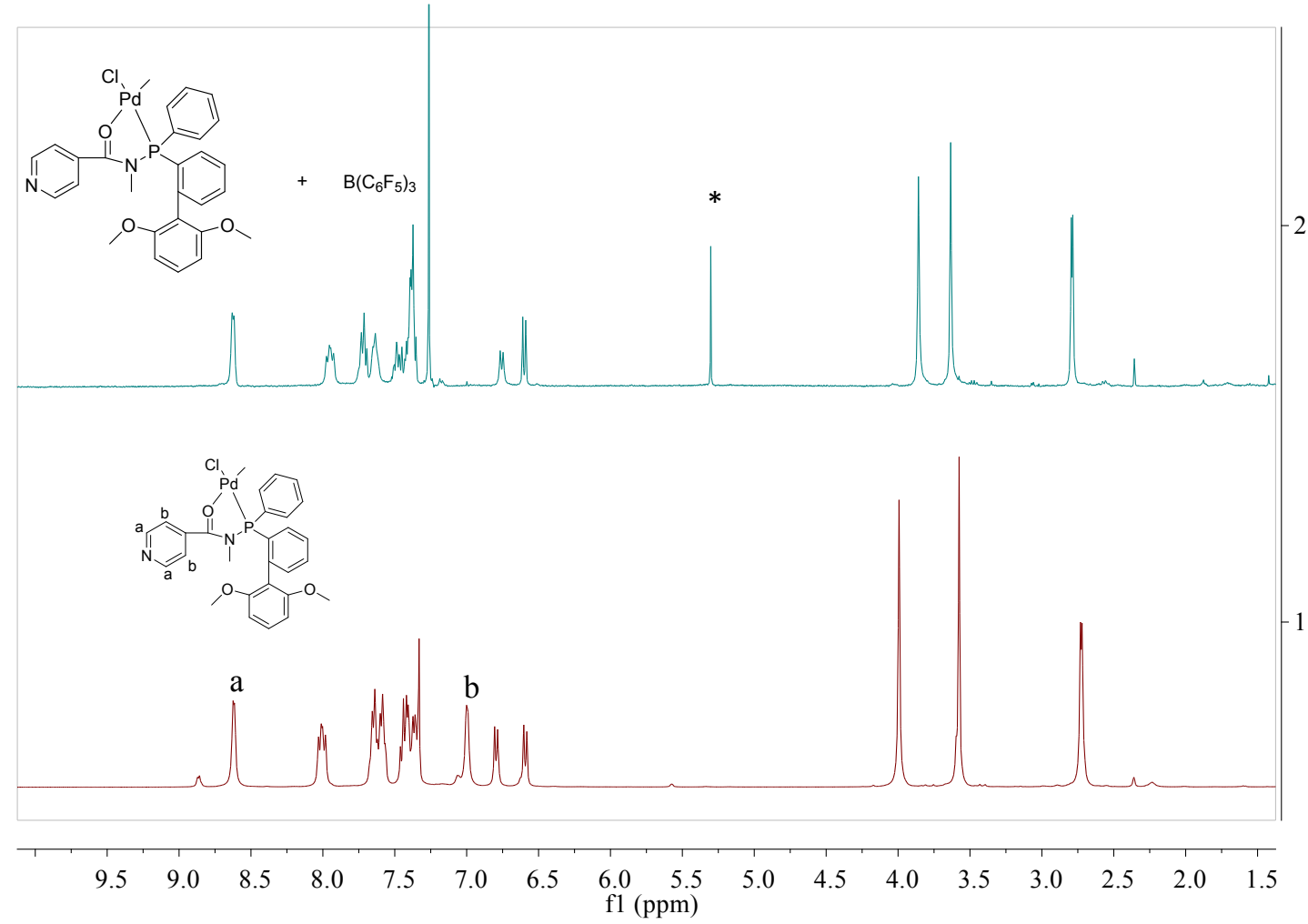

Figure S8. ${ }^{1} \mathrm{H}$ NMR spectrum $\left(400 \mathrm{MHz}, \mathrm{CDCl}_{3}\right)$ of $\mathrm{Pd} 8$ with 1 equivalent of $\mathrm{B}\left(\mathrm{C}_{6} \mathrm{~F}_{5}\right)_{3}$. ${ }^{*} \mathrm{DCM}$. 


\section{Characterization of Ligands and Catalysts.}

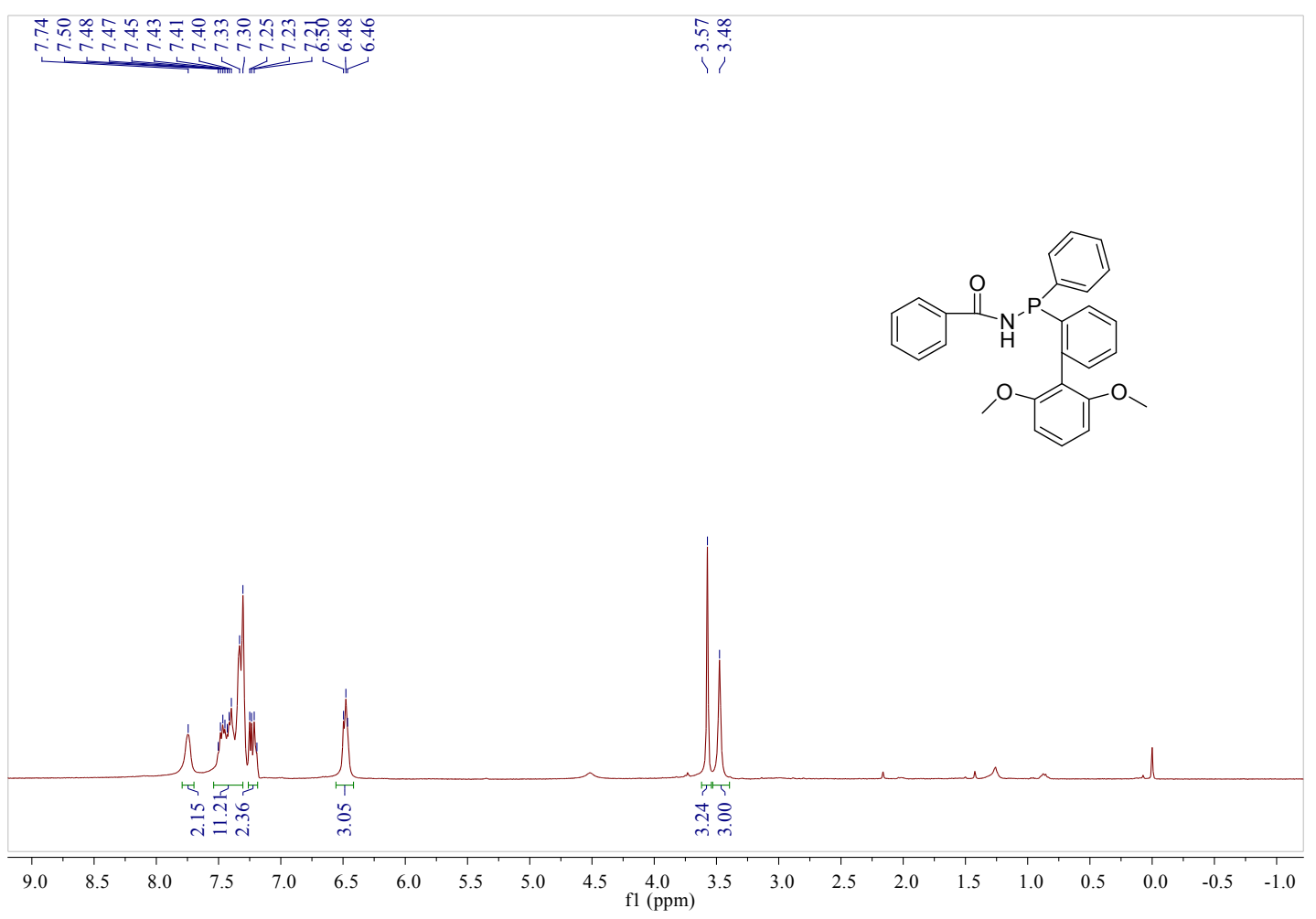

Figure S9. ${ }^{1} \mathrm{H}$ NMR spectrum $\left(400 \mathrm{MHz}, \mathrm{CDCl}_{3}\right)$ of $\mathbf{L 1}$.

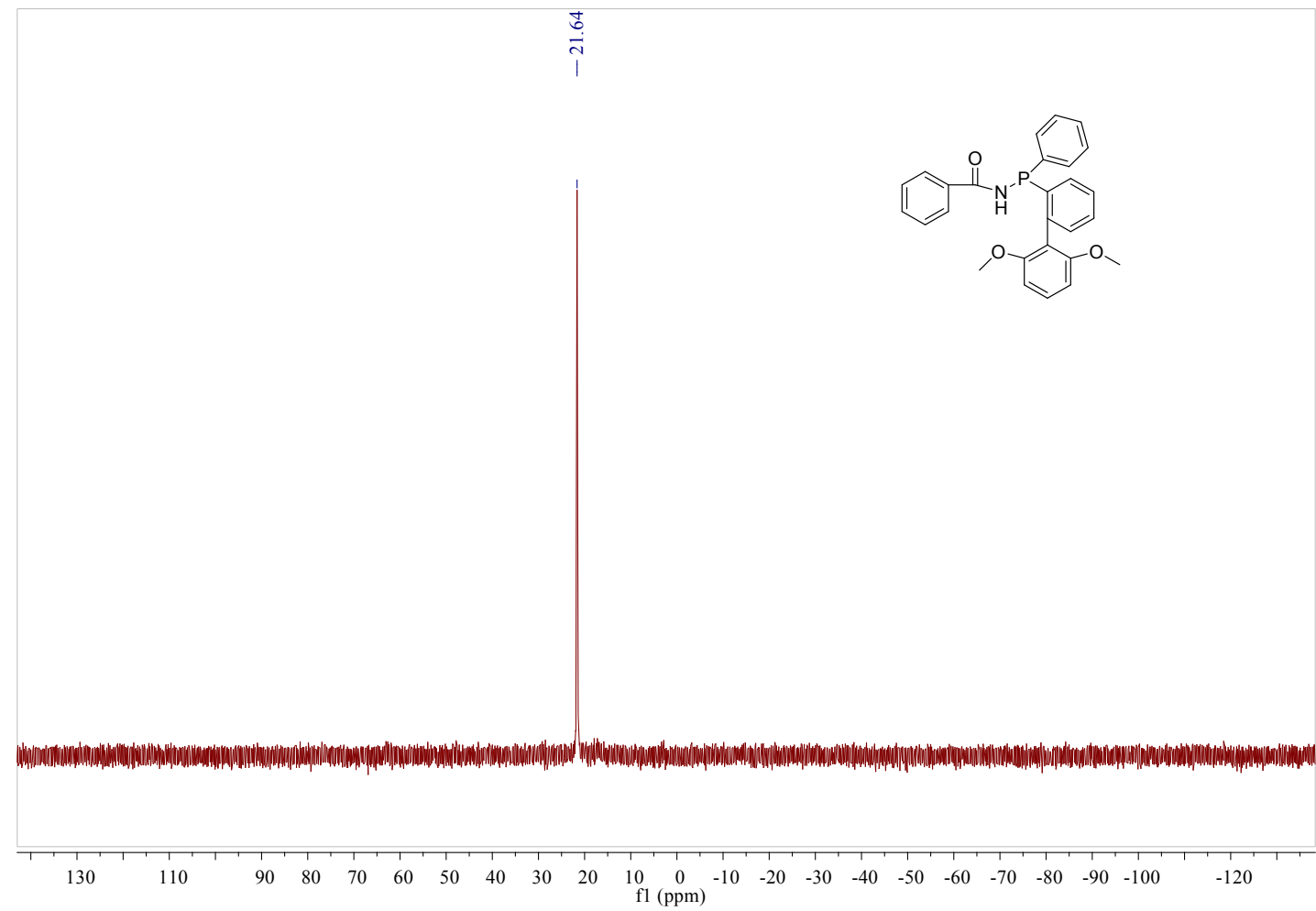

Figure S10. ${ }^{31} \mathrm{P}$ NMR spectrum $\left(\mathrm{CDCl}_{3}\right)$ of $\mathbf{L 1}$. 


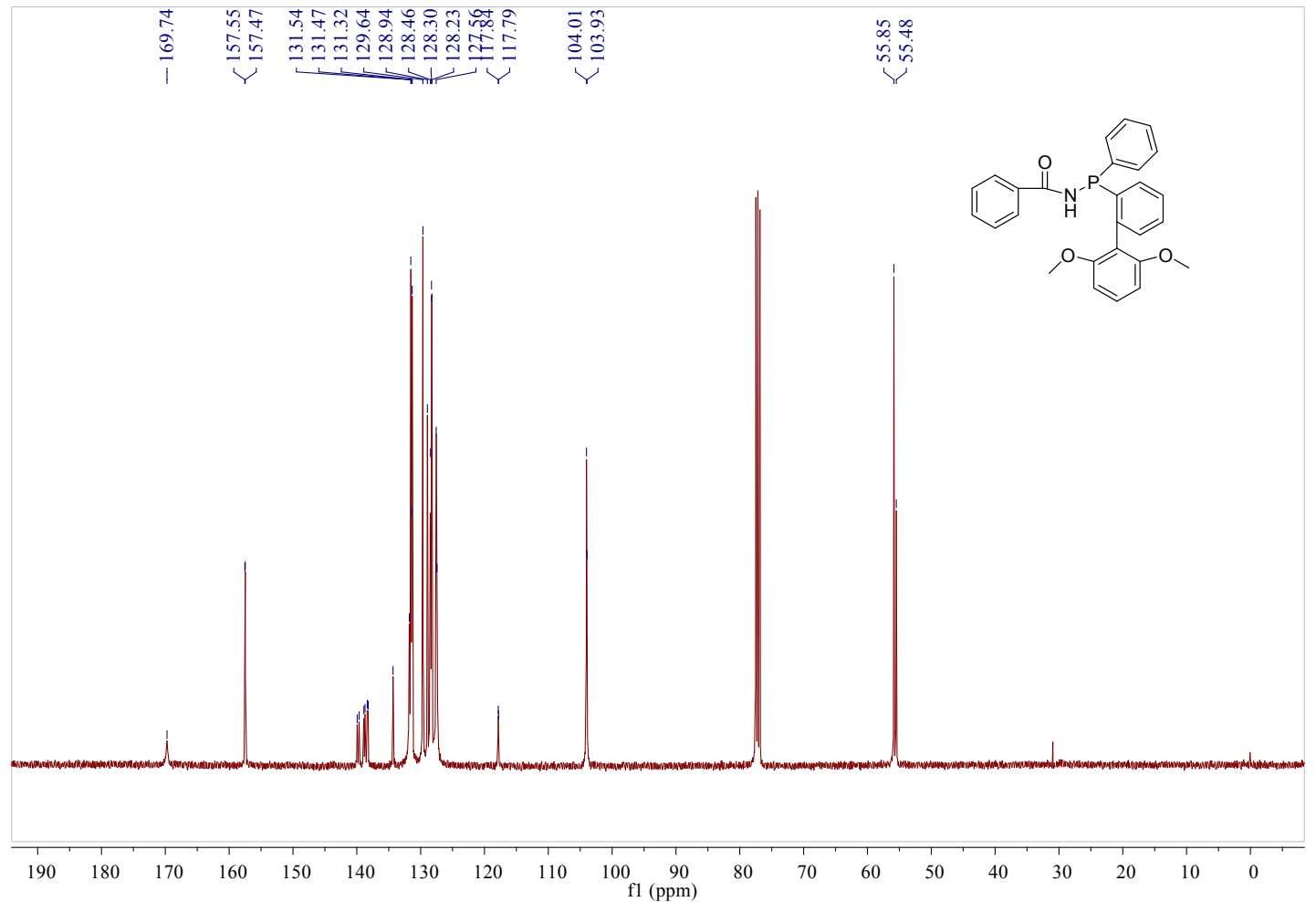

Figure S11. ${ }^{13} \mathrm{C}$ NMR spectrum in $\mathrm{CDCl}_{3}$ of $\mathbf{L 1}$.

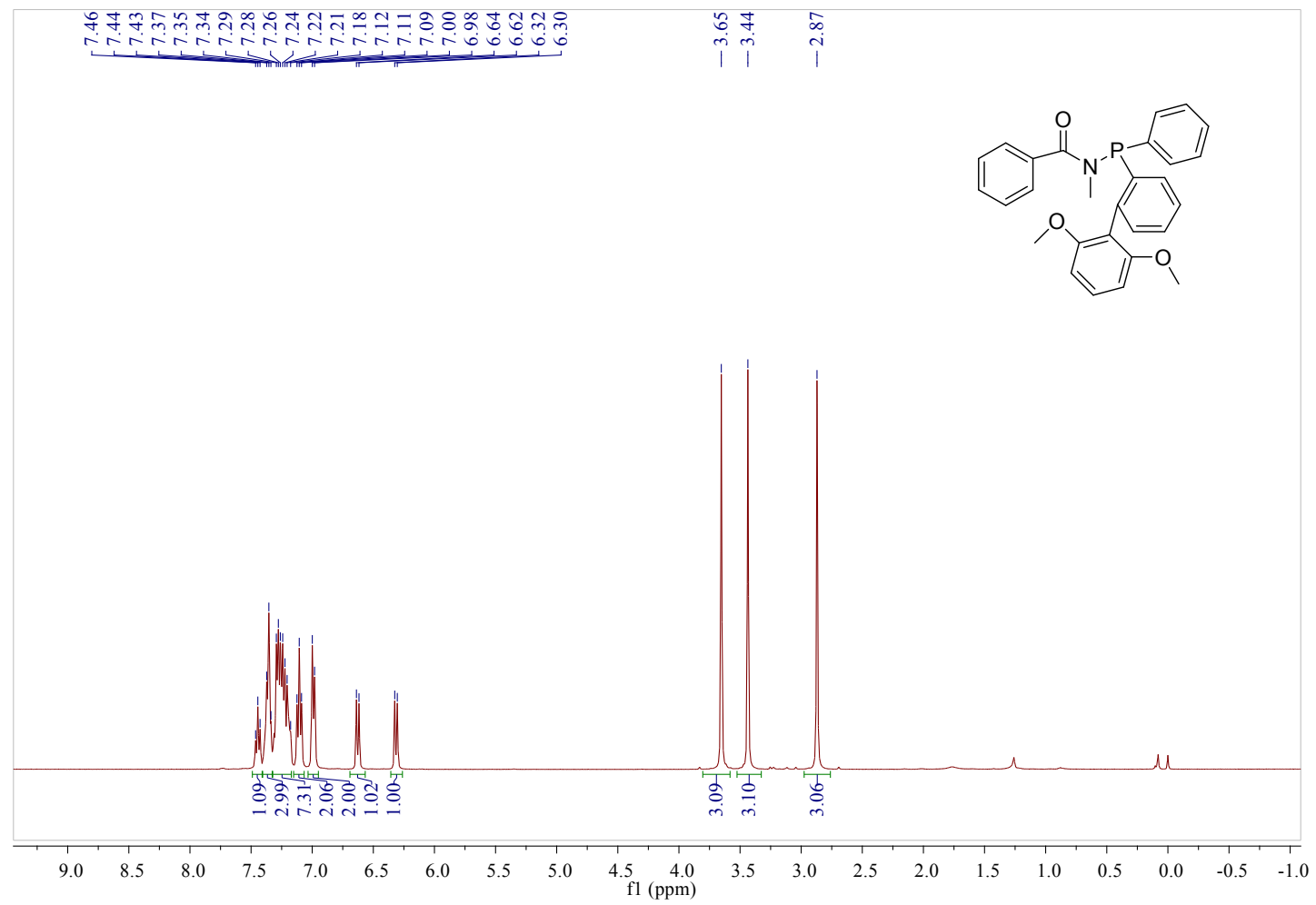

Figure S12. ${ }^{1} \mathrm{H}$ NMR spectrum $\left(400 \mathrm{MHz}, \mathrm{CDCl}_{3}\right)$ of $\mathbf{L 2}$. 


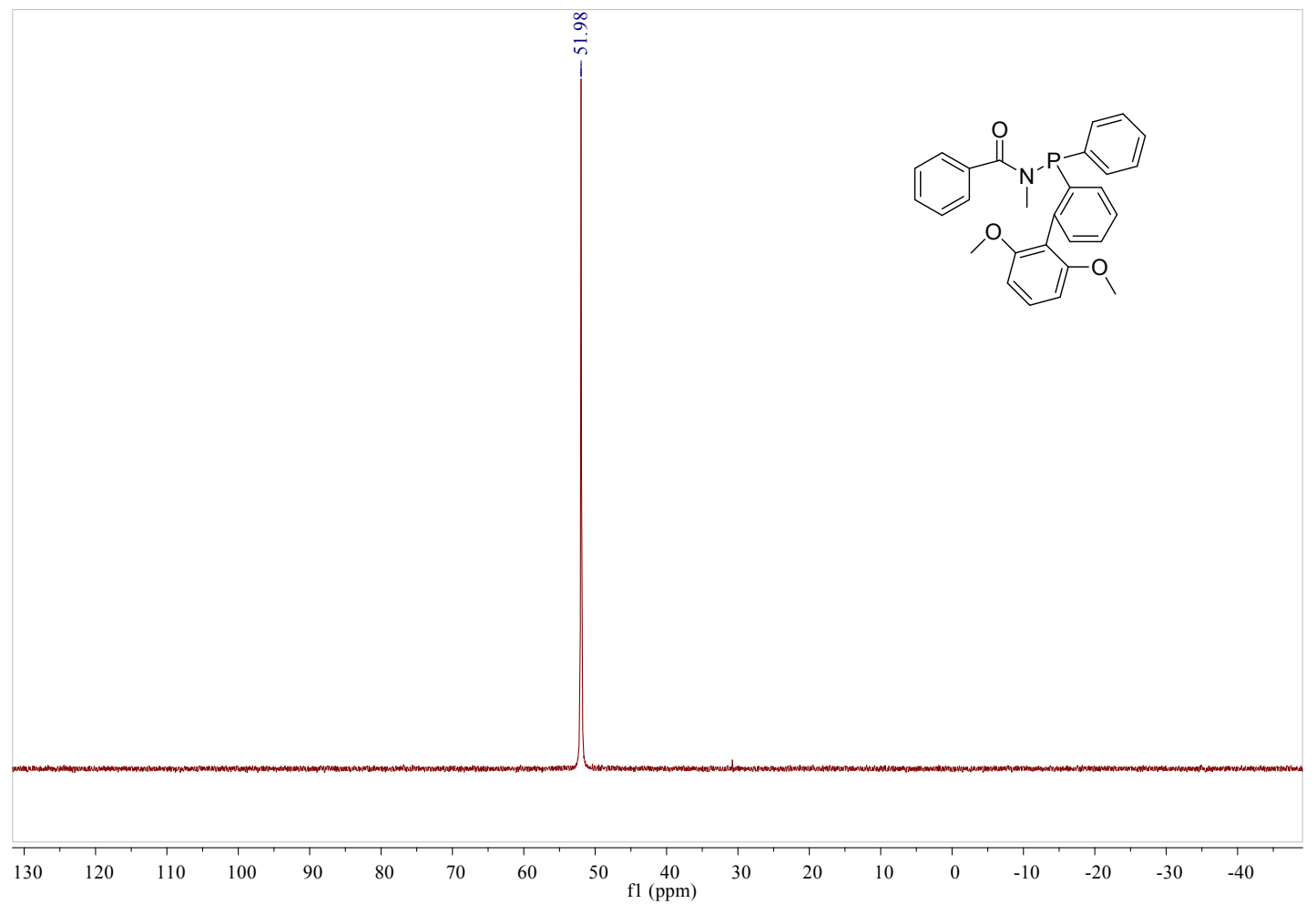

Figure S13. ${ }^{31} \mathrm{P}$ NMR spectrum $\left(\mathrm{CDCl}_{3}\right)$ of $\mathbf{L} 2$.

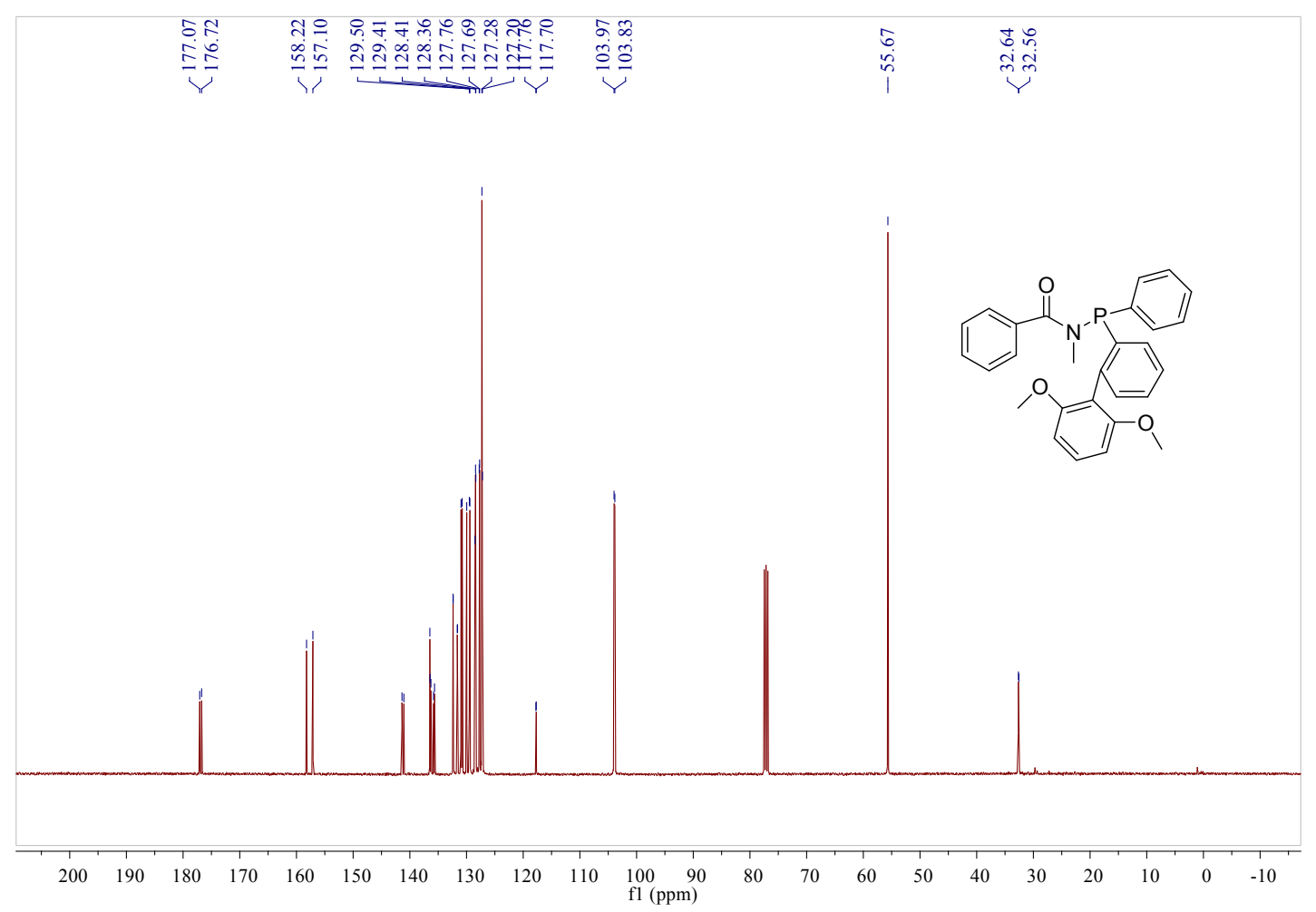

Figure S14. ${ }^{13} \mathrm{C}$ NMR spectrum in $\mathrm{CDCl}_{3}$ of $\mathbf{L 2}$. 


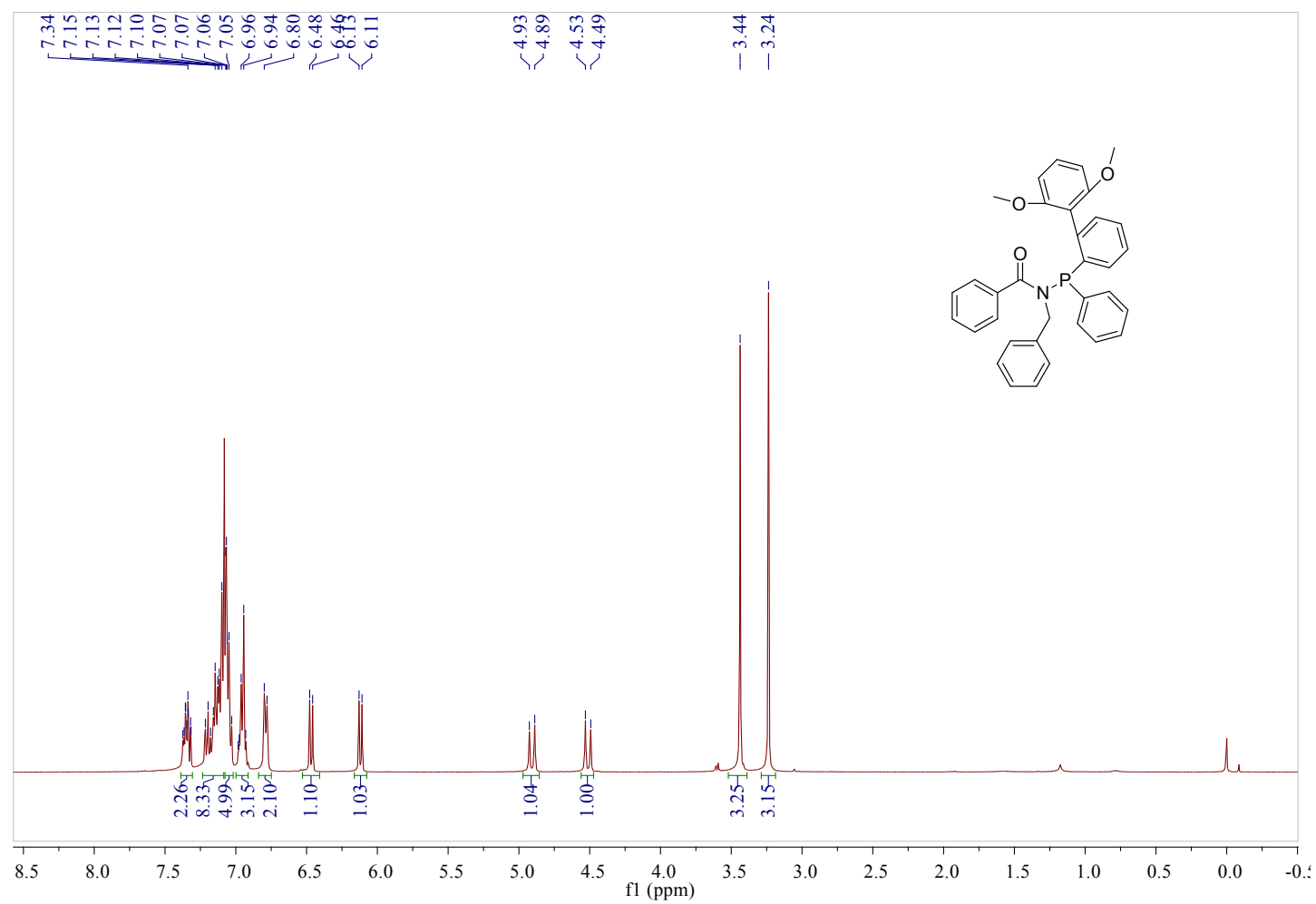

Figure S15. ${ }^{1} \mathrm{H}$ NMR spectrum ( $400 \mathrm{MHz}, \mathrm{CDCl}_{3}$ ) of $\mathbf{L 3}$.

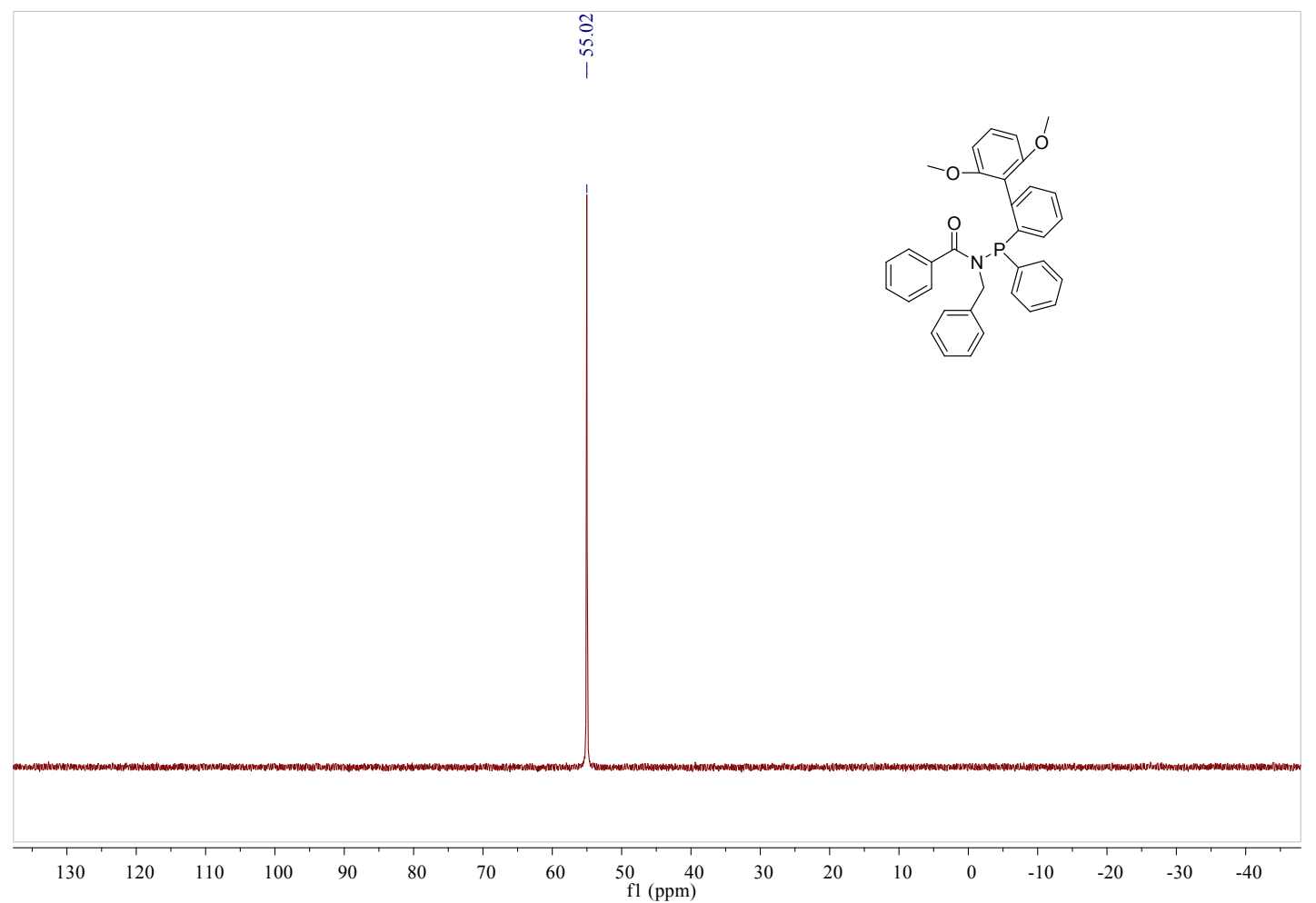

Figure S16. ${ }^{31} \mathrm{P}$ NMR spectrum $\left(\mathrm{CDCl}_{3}\right)$ of $\mathbf{L 3}$. 


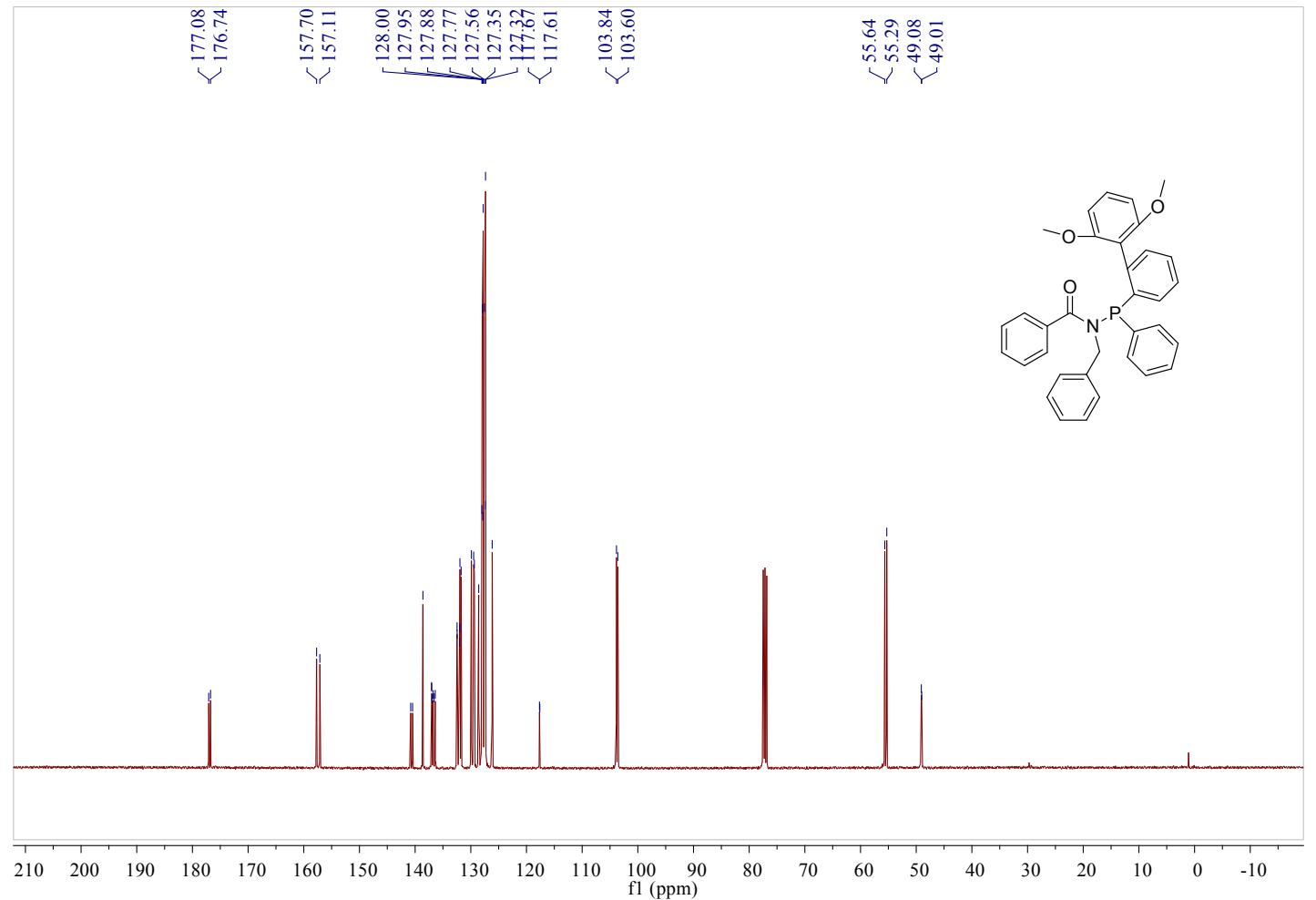

Figure S17. ${ }^{13} \mathrm{C}$ NMR spectrum in $\mathrm{CDCl}_{3}$ of $\mathbf{L 3}$.

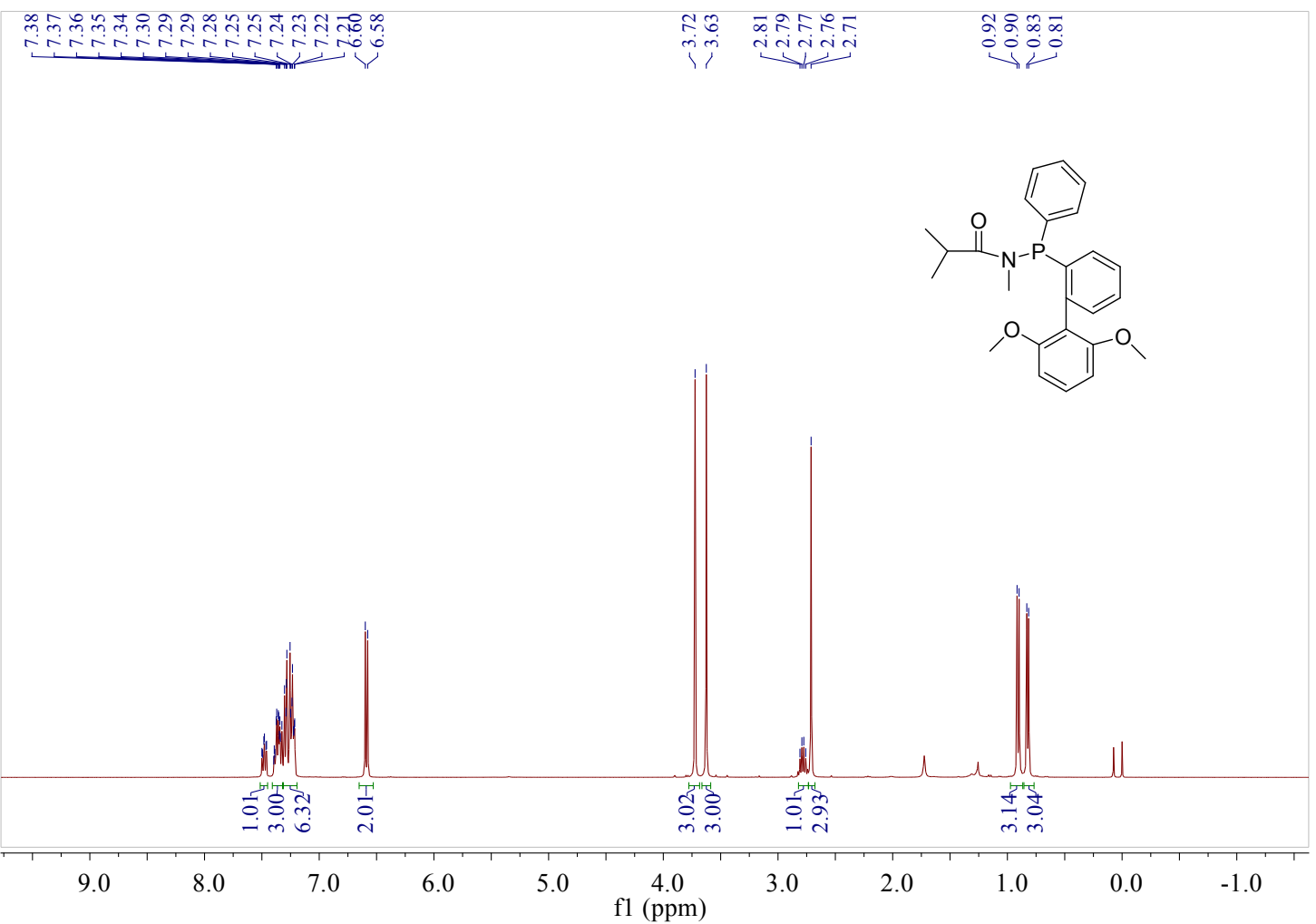

Figure S18. ${ }^{1} \mathrm{H}$ NMR spectrum $\left(400 \mathrm{MHz}, \mathrm{CDCl}_{3}\right)$ of $\mathbf{L 4}$. 


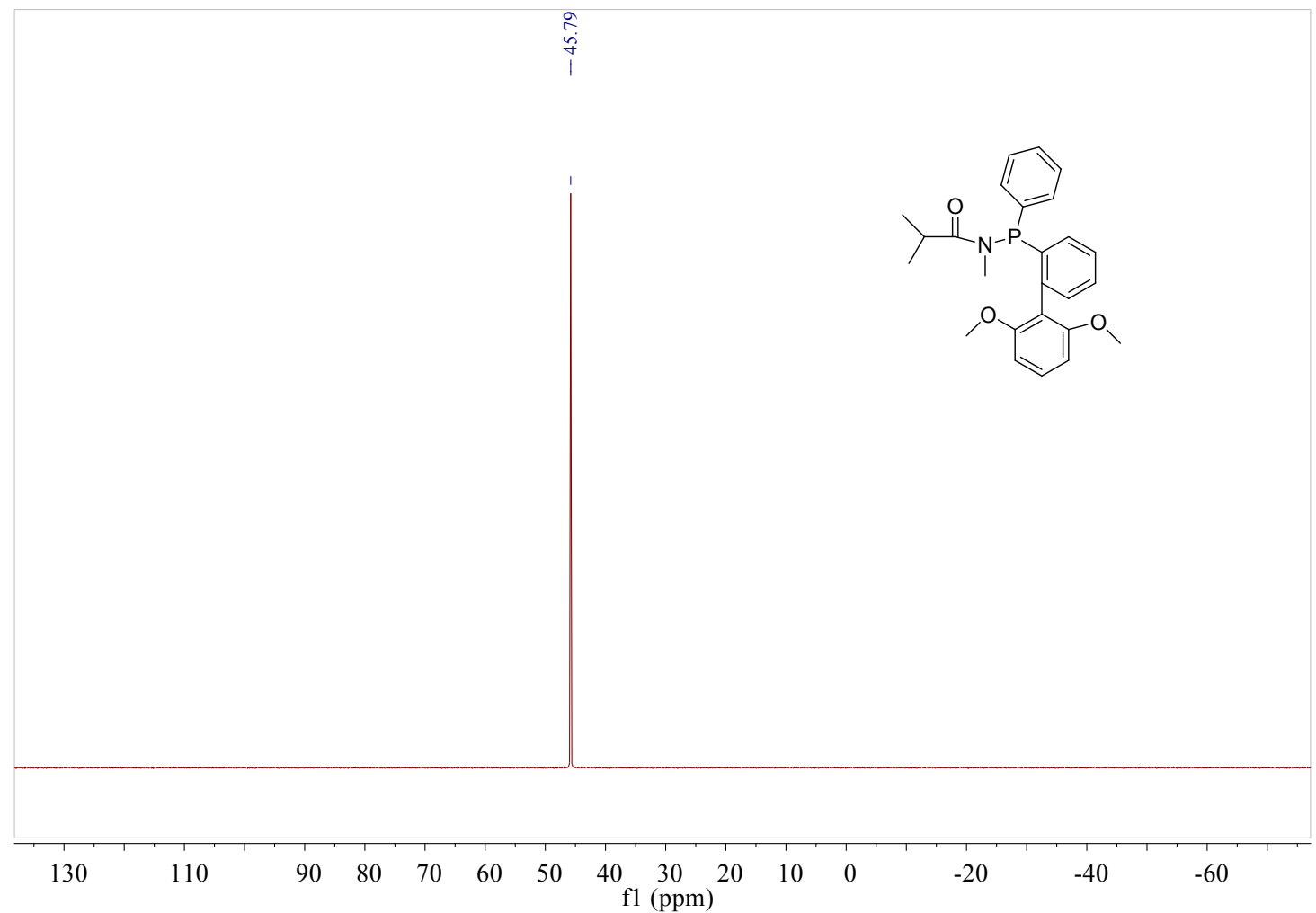

Figure S19. ${ }^{31} \mathrm{P}$ NMR spectrum $\left(\mathrm{CDCl}_{3}\right)$ of $\mathbf{L 4}$.

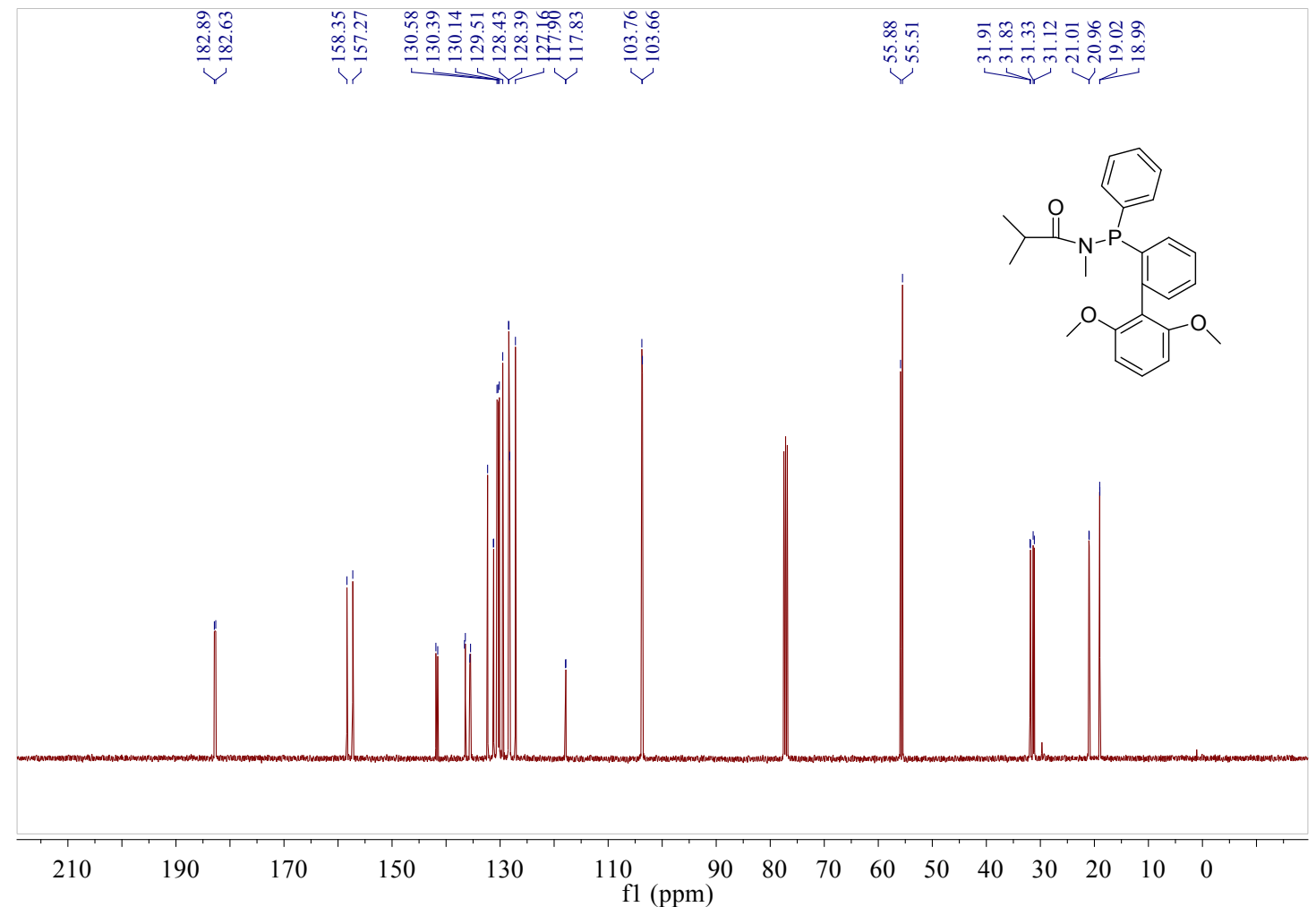

Figure S20. ${ }^{13} \mathrm{C}$ NMR spectrum in $\mathrm{CDCl}_{3}$ of $\mathbf{L 4}$. 


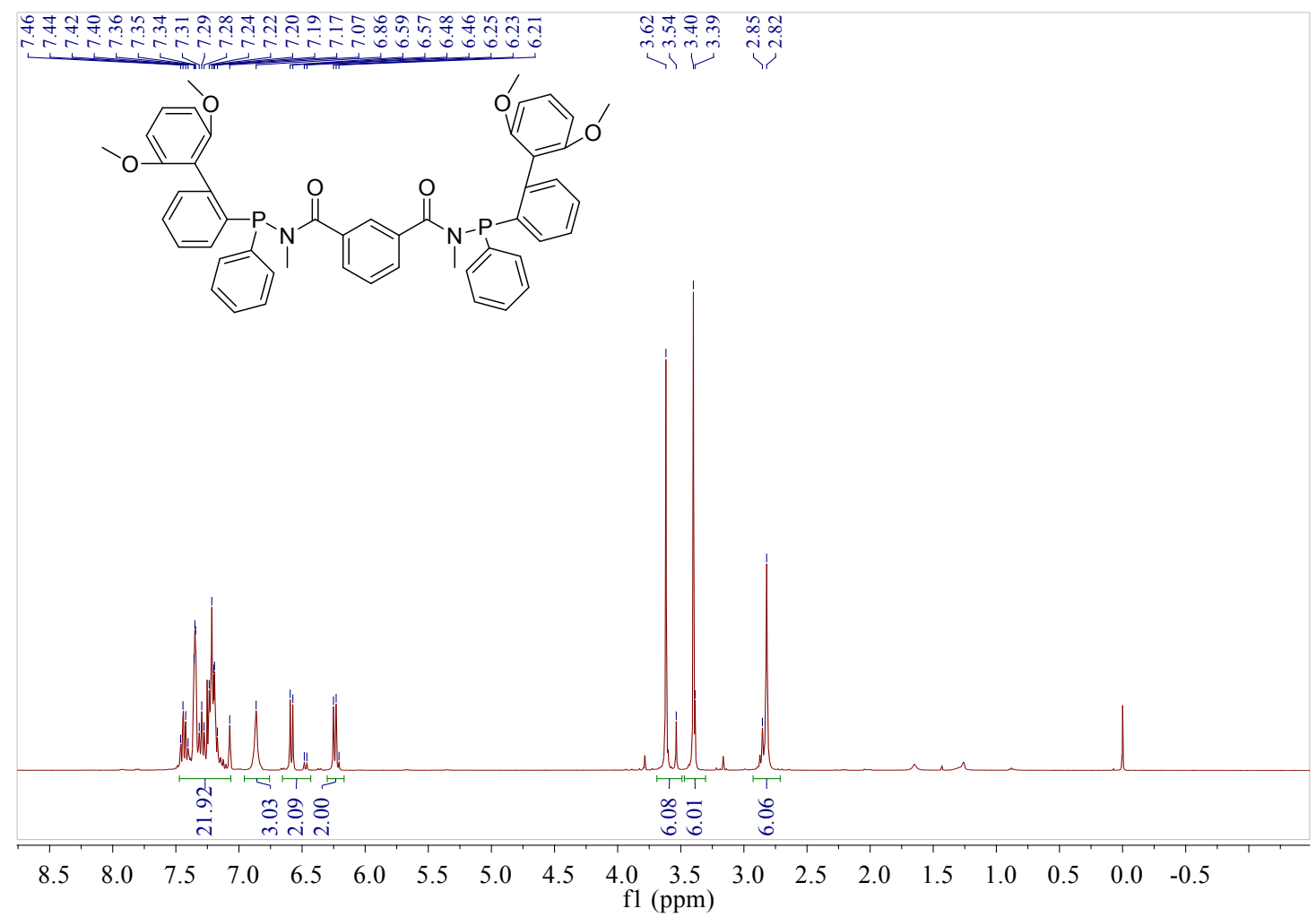

Figure S21. ${ }^{1} \mathrm{H}$ NMR spectrum $\left(400 \mathrm{MHz}, \mathrm{CDCl}_{3}\right)$ of $\mathbf{L 5}$.

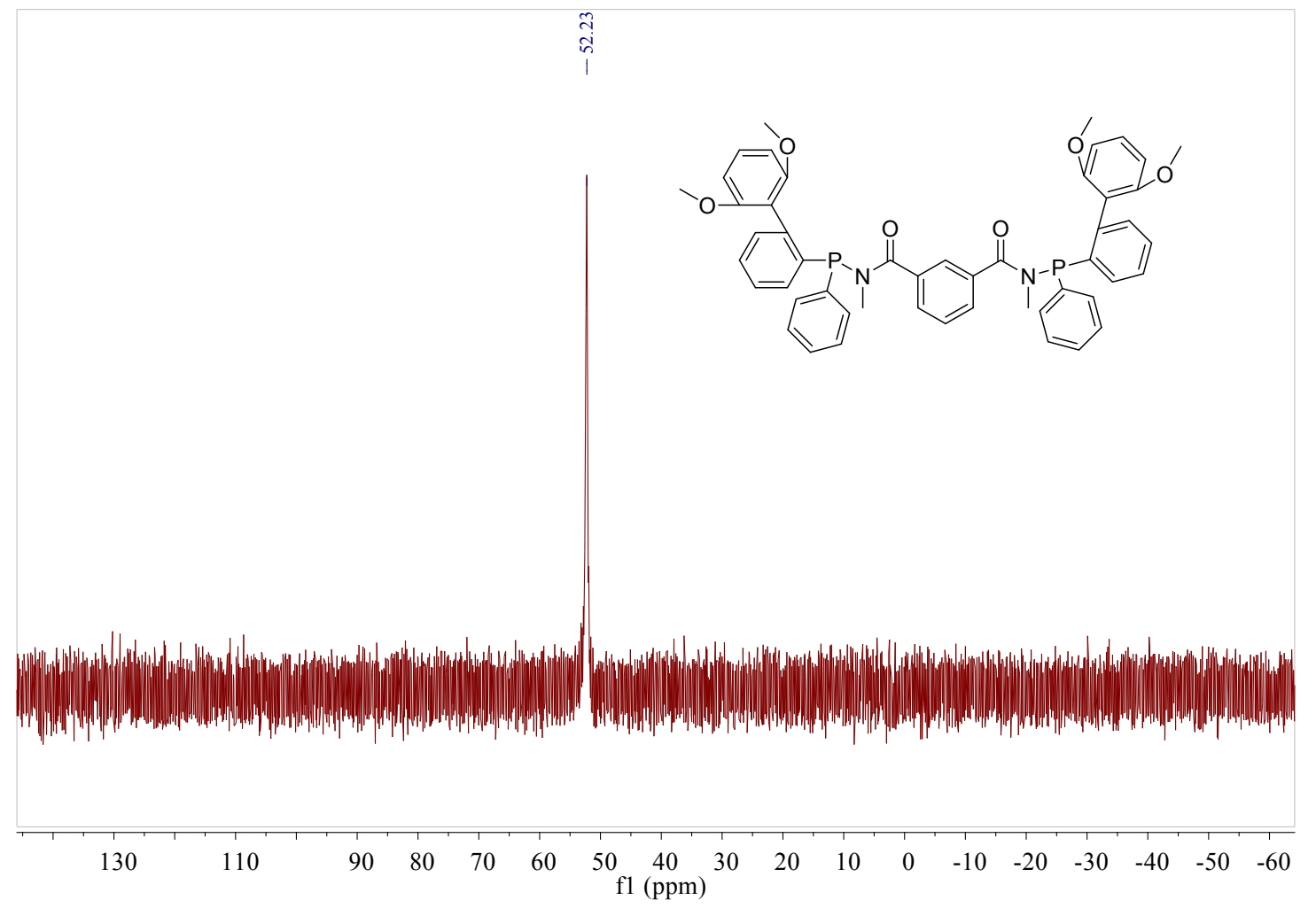

Figure S22. ${ }^{31} \mathrm{P}$ NMR spectrum $\left(\mathrm{CDCl}_{3}\right)$ of $\mathbf{L 5}$. 


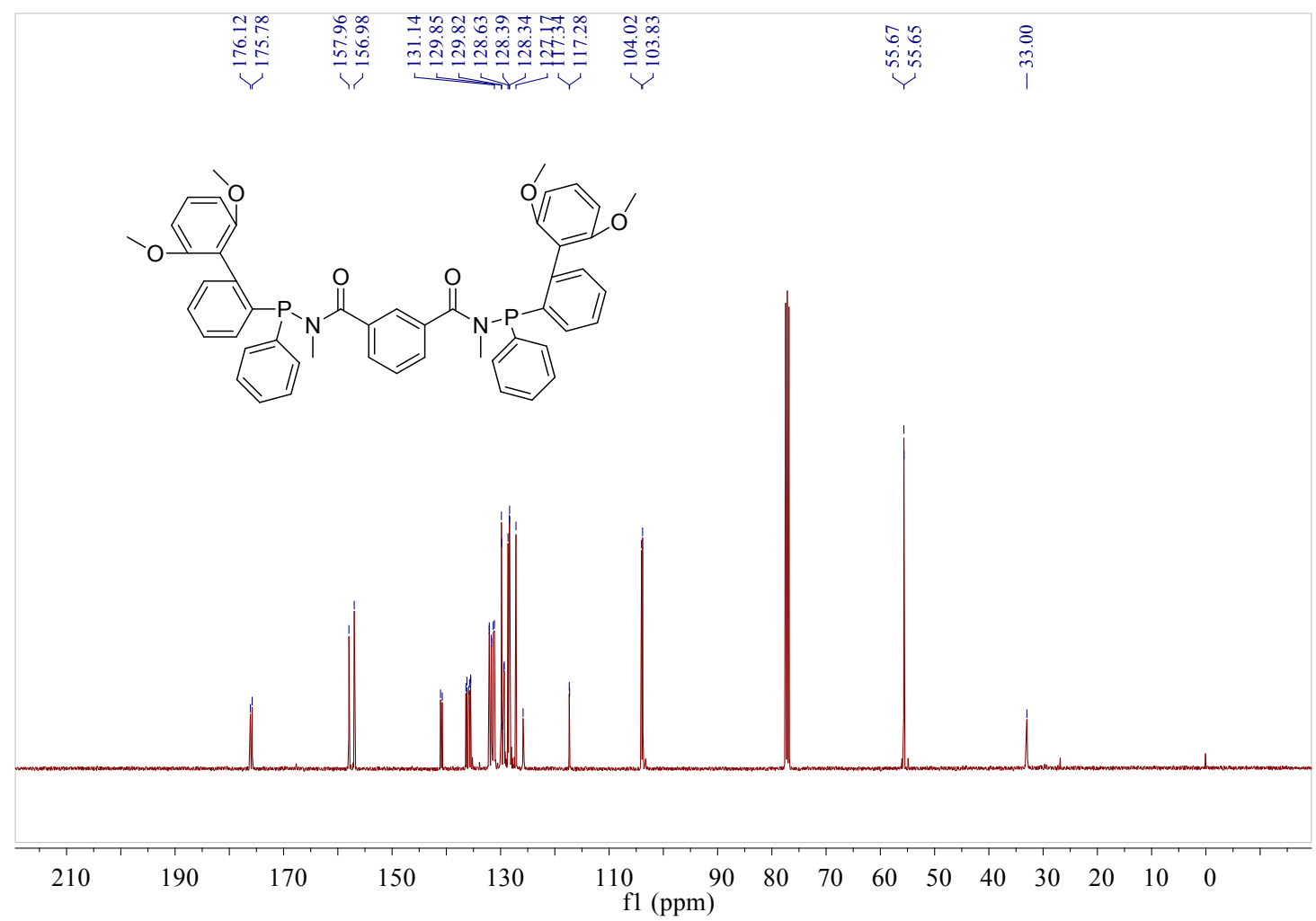

Figure S23. ${ }^{13} \mathrm{C}$ NMR spectrum in $\mathrm{CDCl}_{3}$ of $\mathbf{L 5}$.

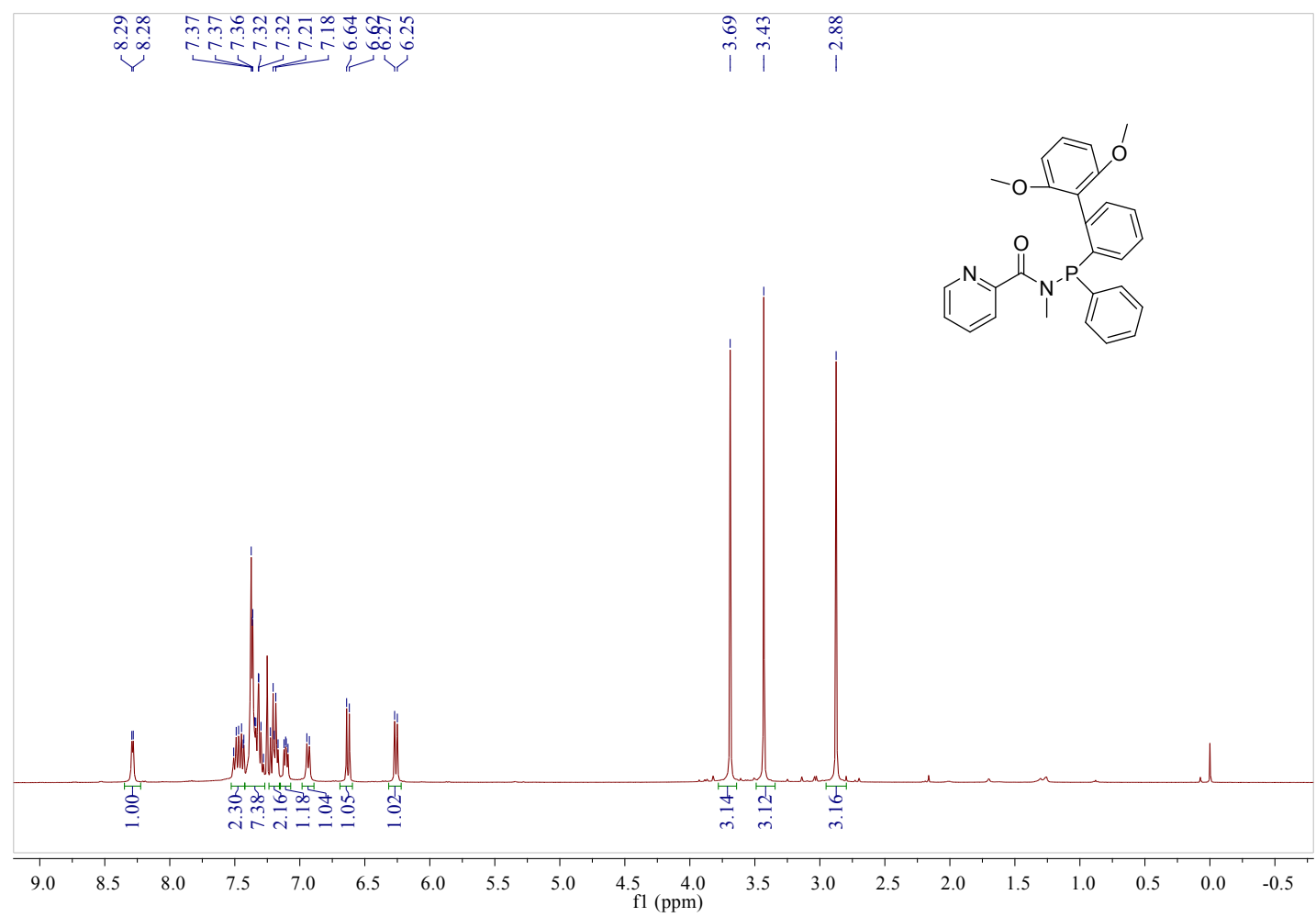

Figure S24. ${ }^{1} \mathrm{H}$ NMR spectrum $\left(400 \mathrm{MHz}, \mathrm{CDCl}_{3}\right)$ of $\mathbf{L 6}$. 


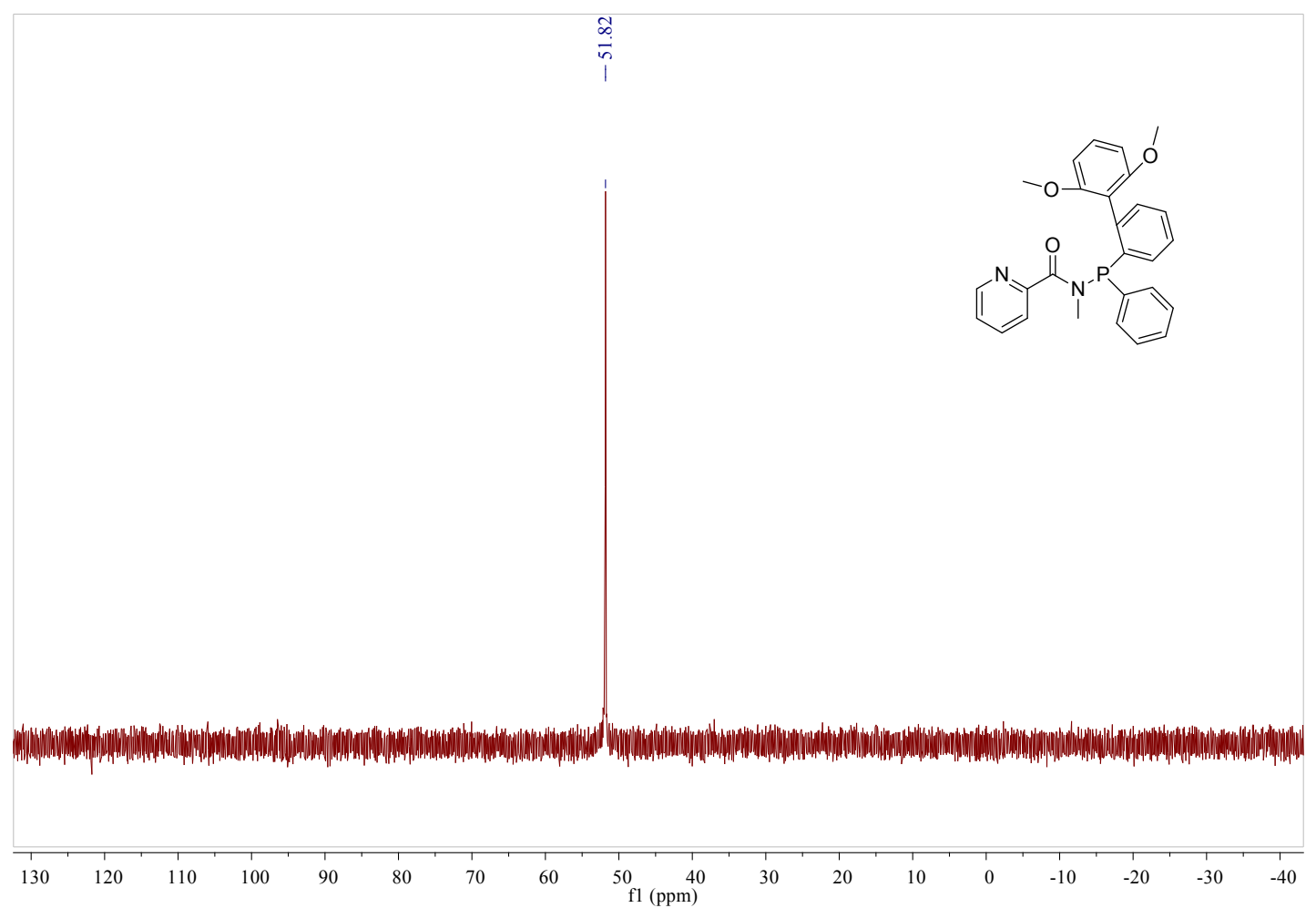

Figure S25. ${ }^{31} \mathrm{P}$ NMR spectrum $\left(\mathrm{CDCl}_{3}\right)$ of $\mathbf{L 6}$.

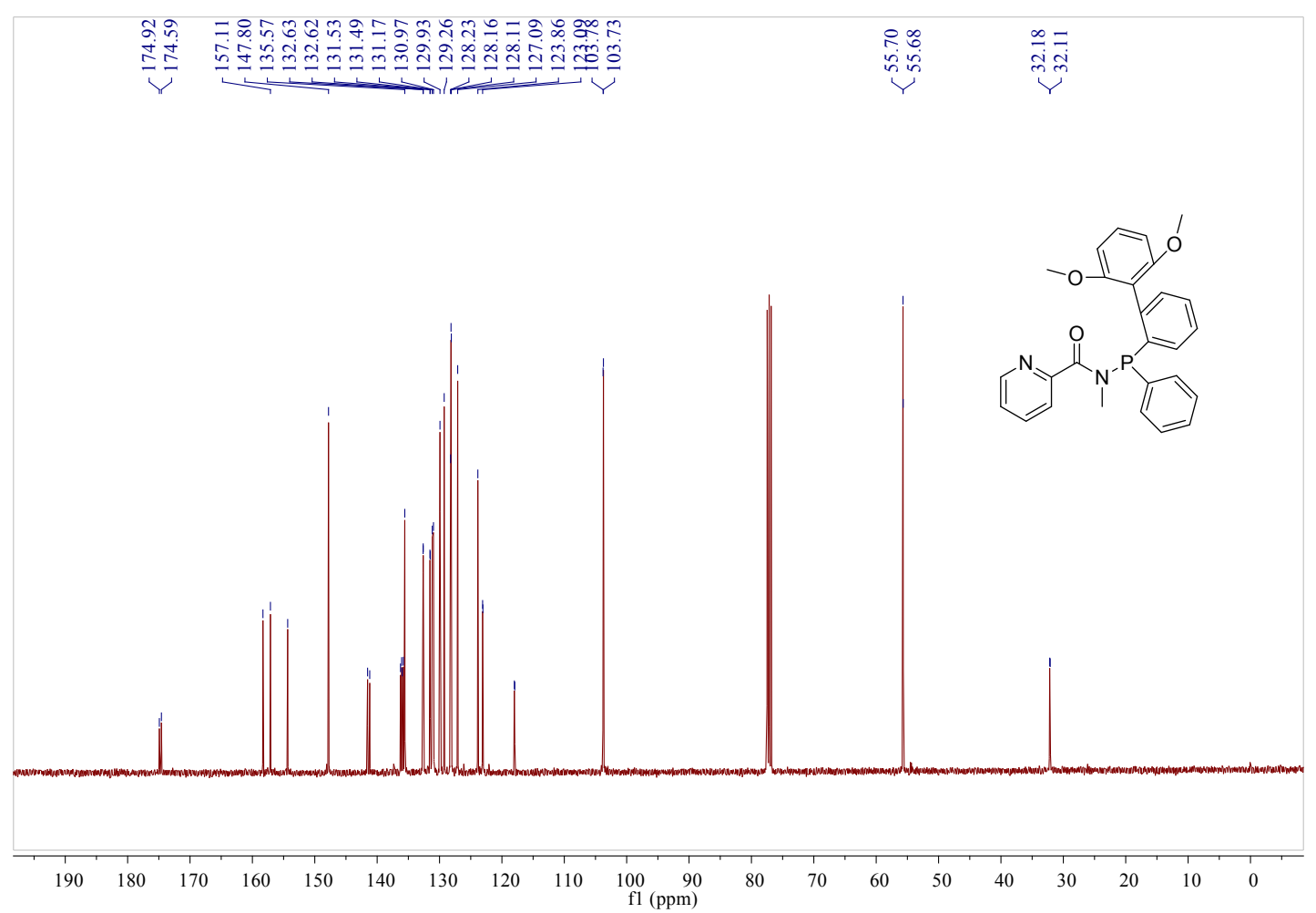

Figure $\mathbf{S 2 6} .{ }^{13} \mathrm{C}$ NMR spectrum in $\mathrm{CDCl}_{3}$ of $\mathbf{L 6}$. 


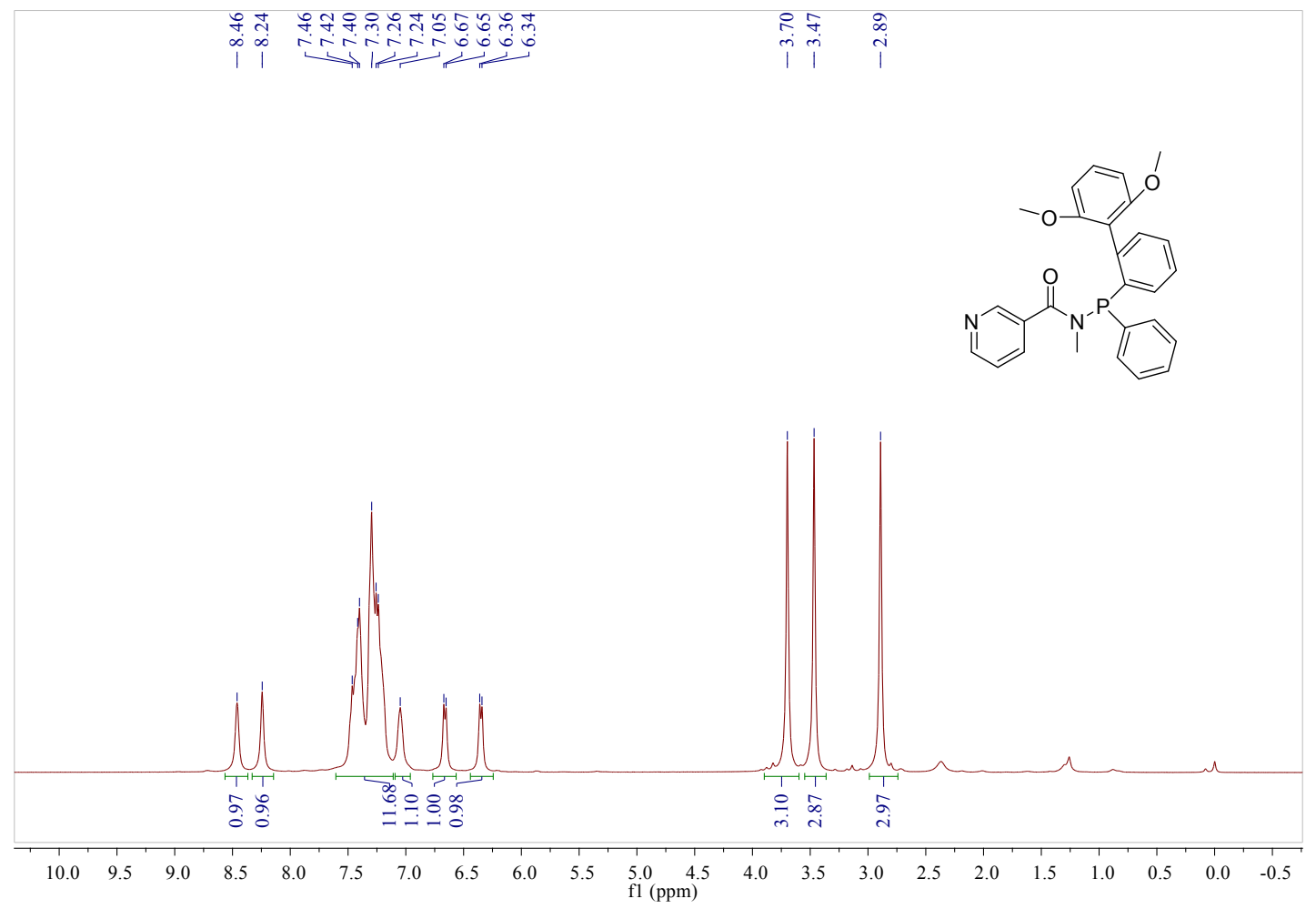

Figure S27. ${ }^{1} \mathrm{H}$ NMR spectrum ( $400 \mathrm{MHz}, \mathrm{CDCl}_{3}$ ) of $\mathbf{L} 7$.

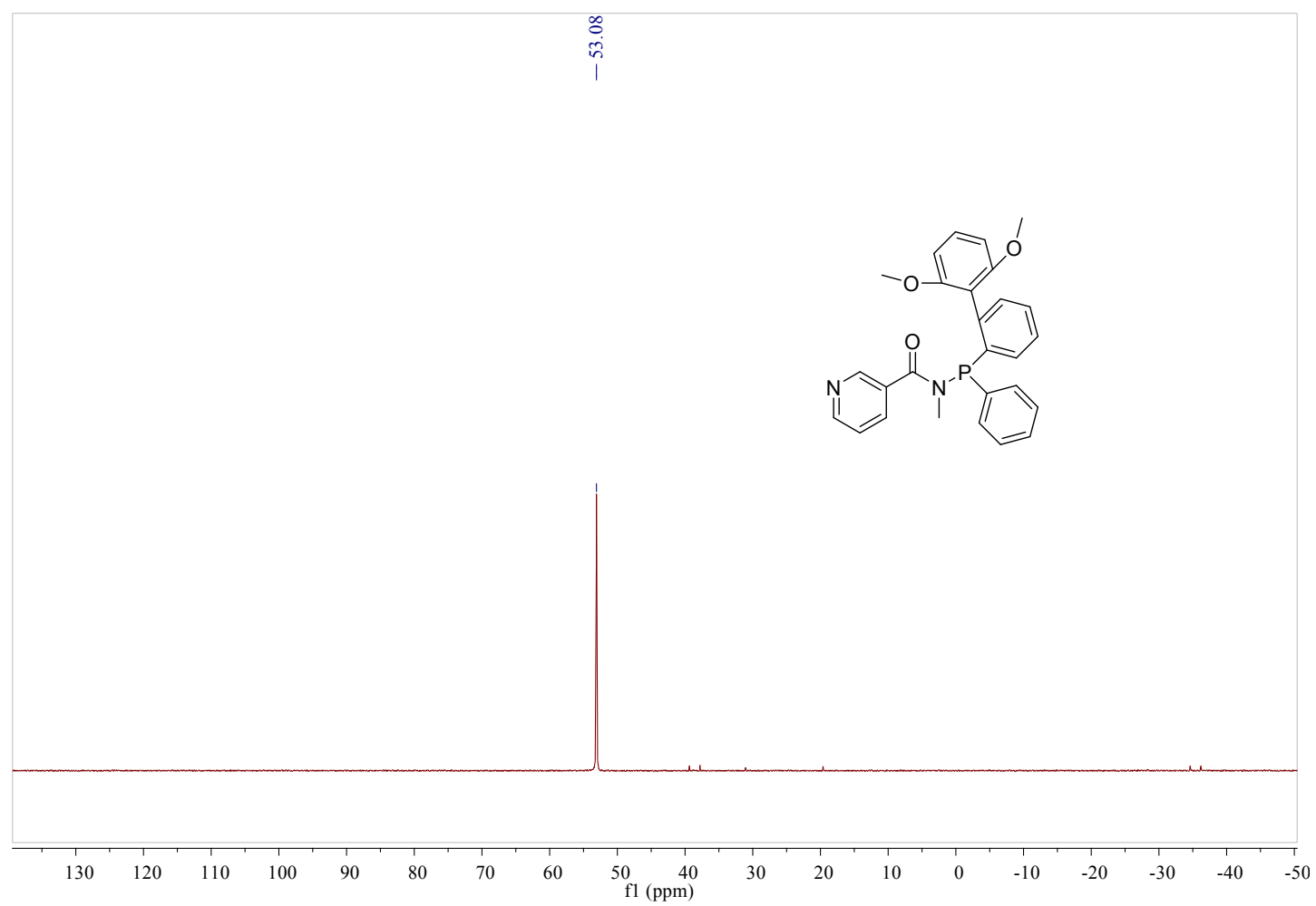

Figure S28. ${ }^{31} \mathrm{P}$ NMR spectrum $\left(\mathrm{CDCl}_{3}\right)$ of $\mathbf{L} 7$. 


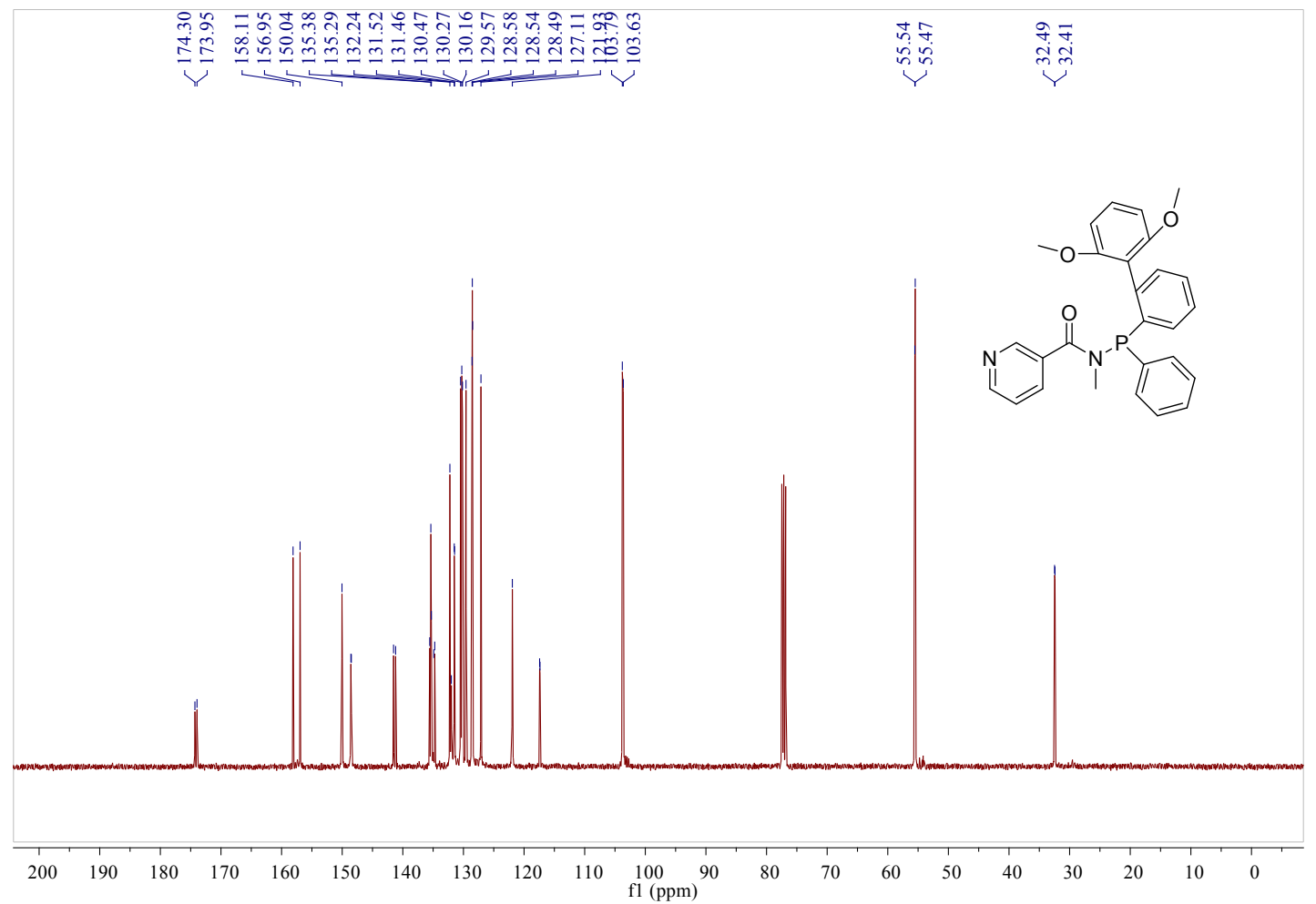

Figure S29. ${ }^{13} \mathrm{C}$ NMR spectrum in $\mathrm{CDCl}_{3}$ of $\mathbf{L} 7$.

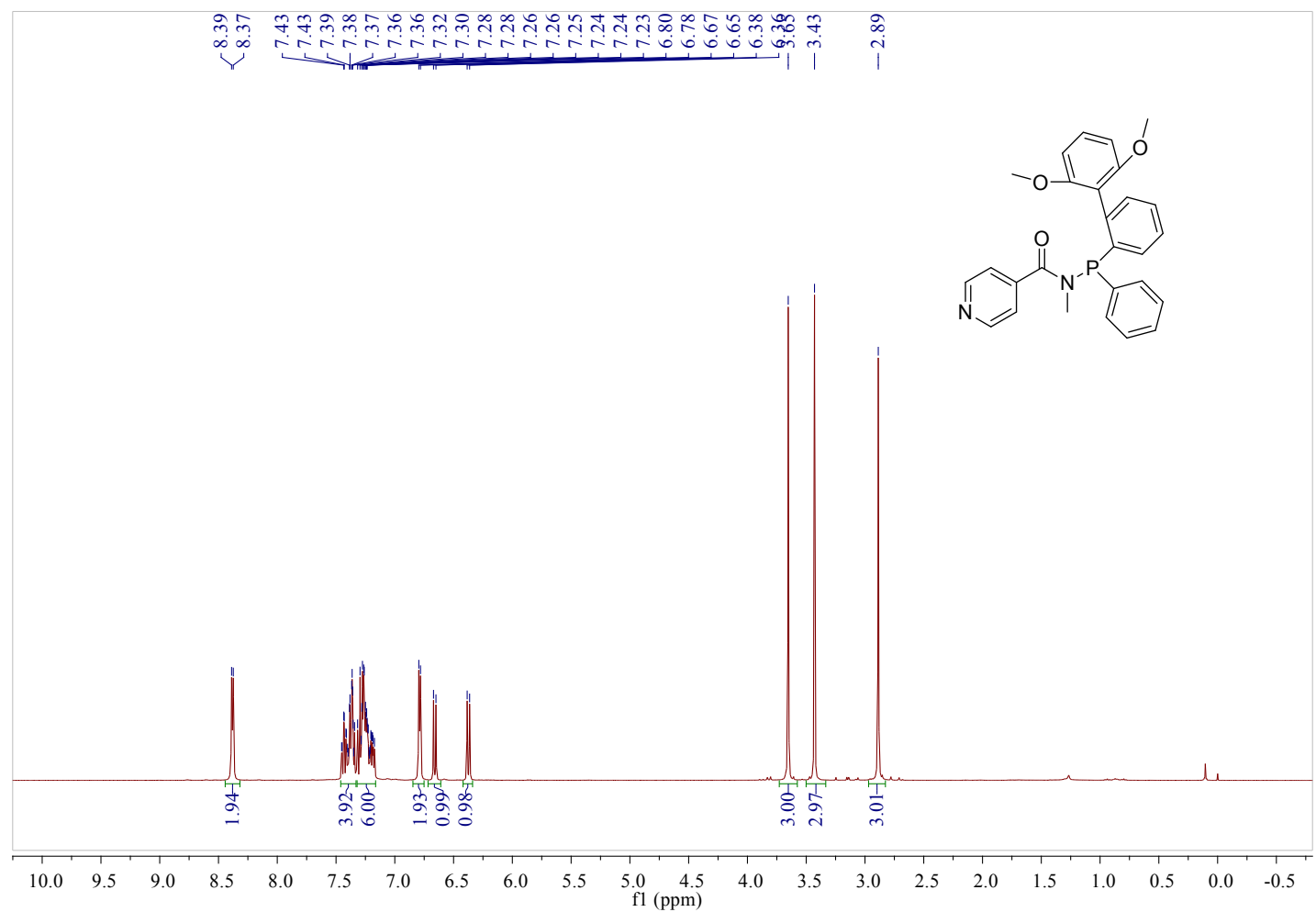

Figure S30. ${ }^{1} \mathrm{H}$ NMR spectrum $\left(400 \mathrm{MHz}, \mathrm{CDCl}_{3}\right)$ of $\mathbf{L 8}$. 


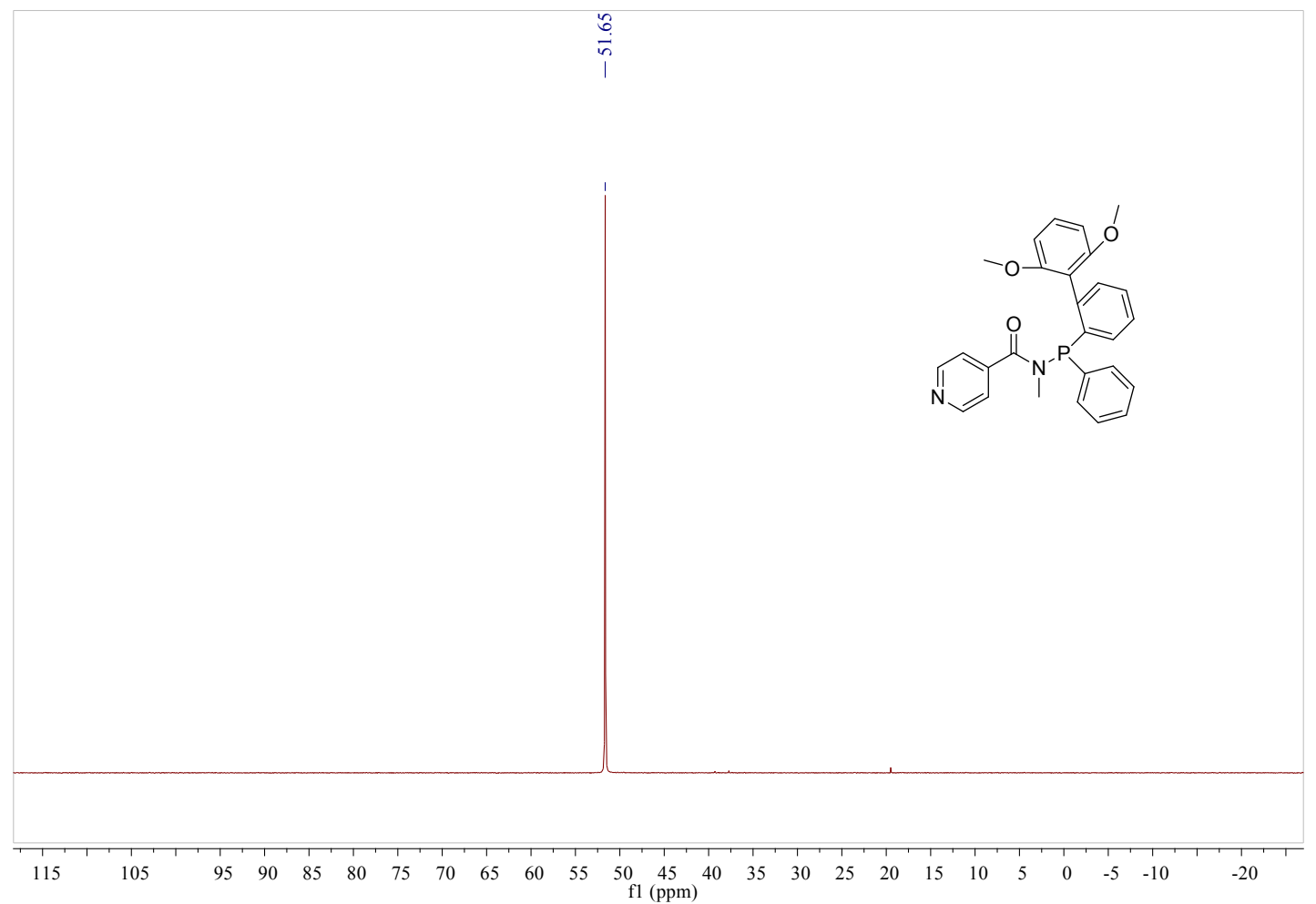

Figure S31. ${ }^{31} \mathrm{P}$ NMR spectrum $\left(\mathrm{CDCl}_{3}\right)$ of $\mathbf{L 8}$.

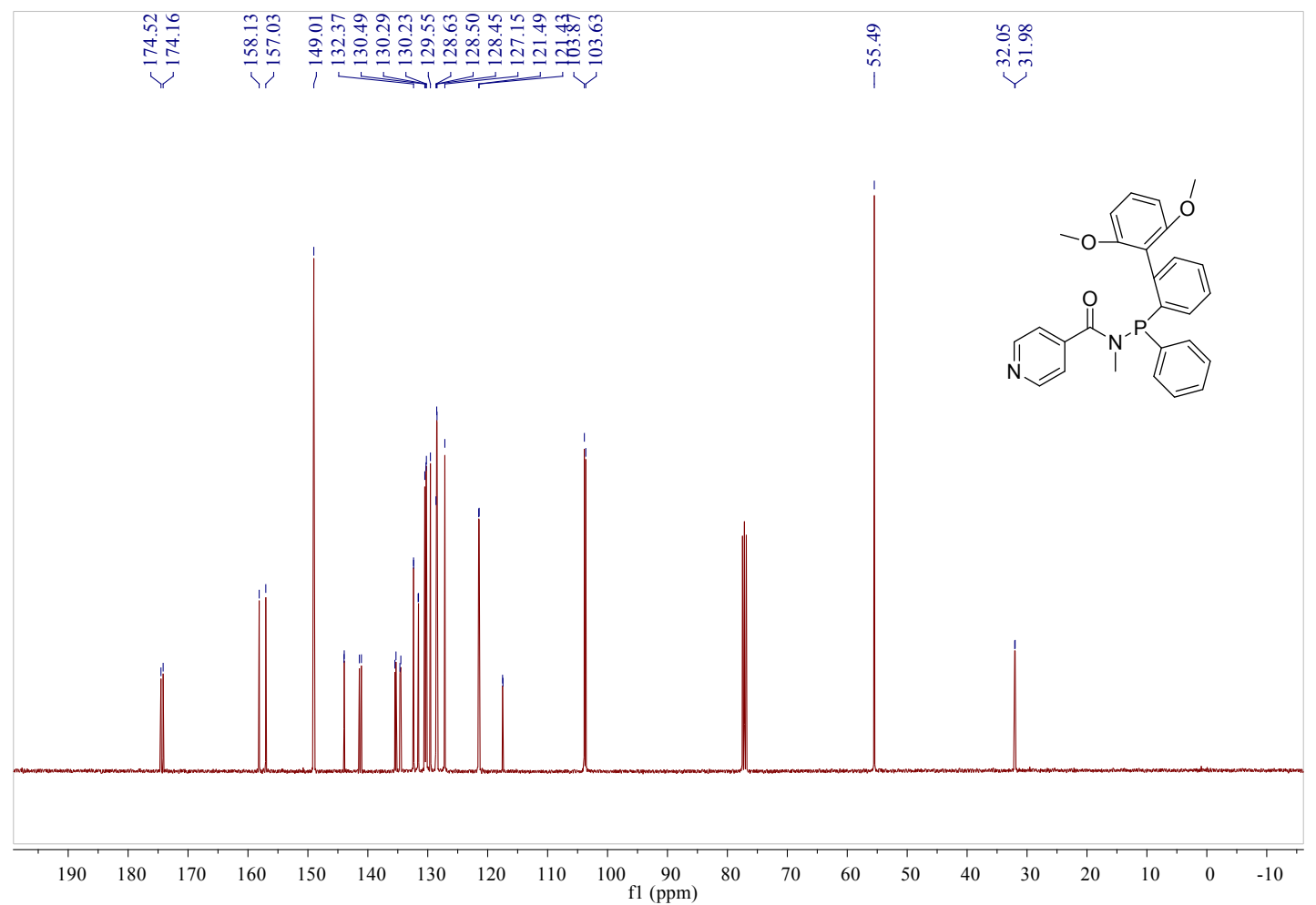

Figure S32. ${ }^{13} \mathrm{C}$ NMR spectrum in $\mathrm{CDCl}_{3}$ of $\mathbf{L 8}$. 


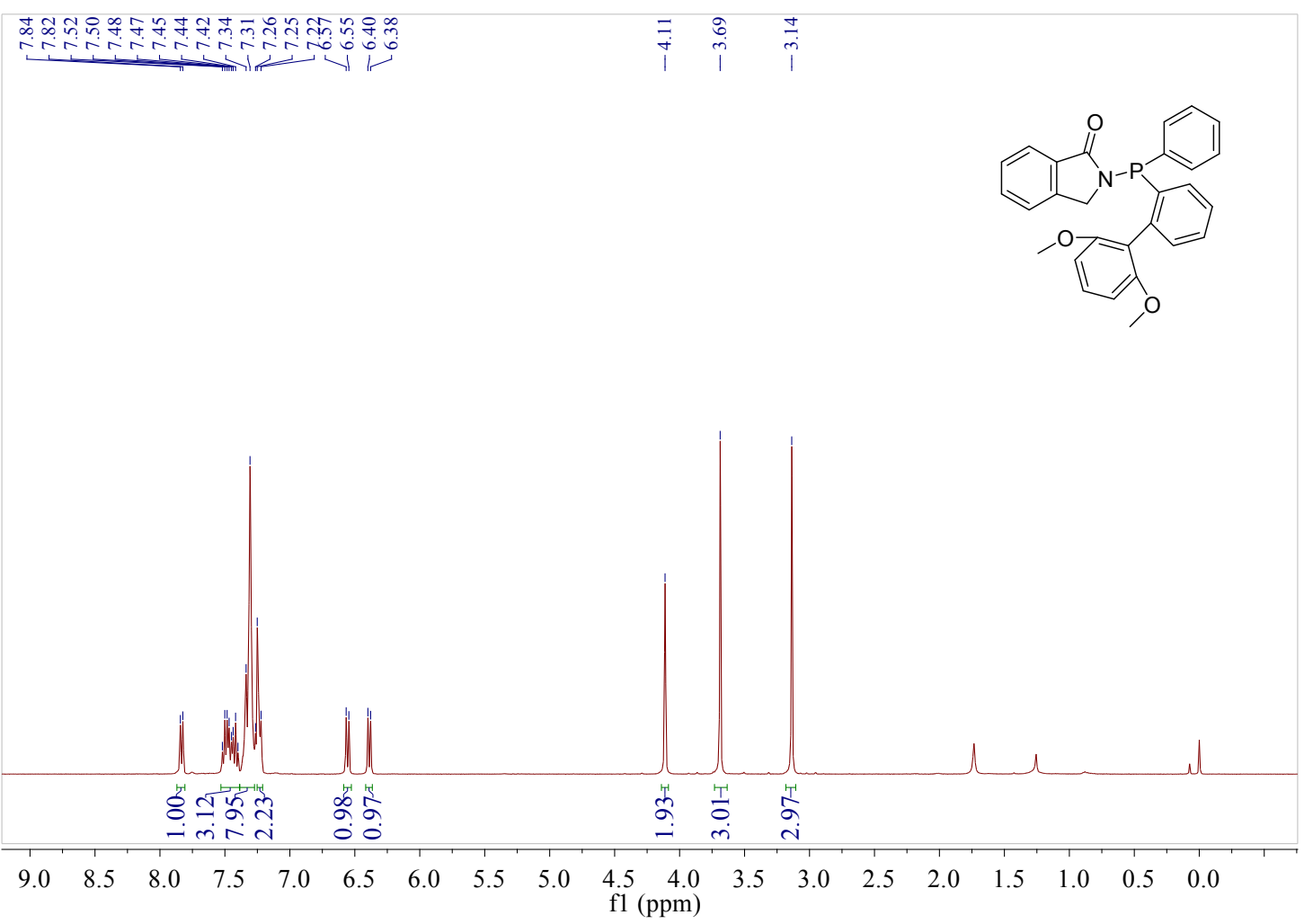

Figure S33. ${ }^{1} \mathrm{H}$ NMR spectrum $\left(400 \mathrm{MHz}, \mathrm{CDCl}_{3}\right)$ of $\mathbf{L 9}$.

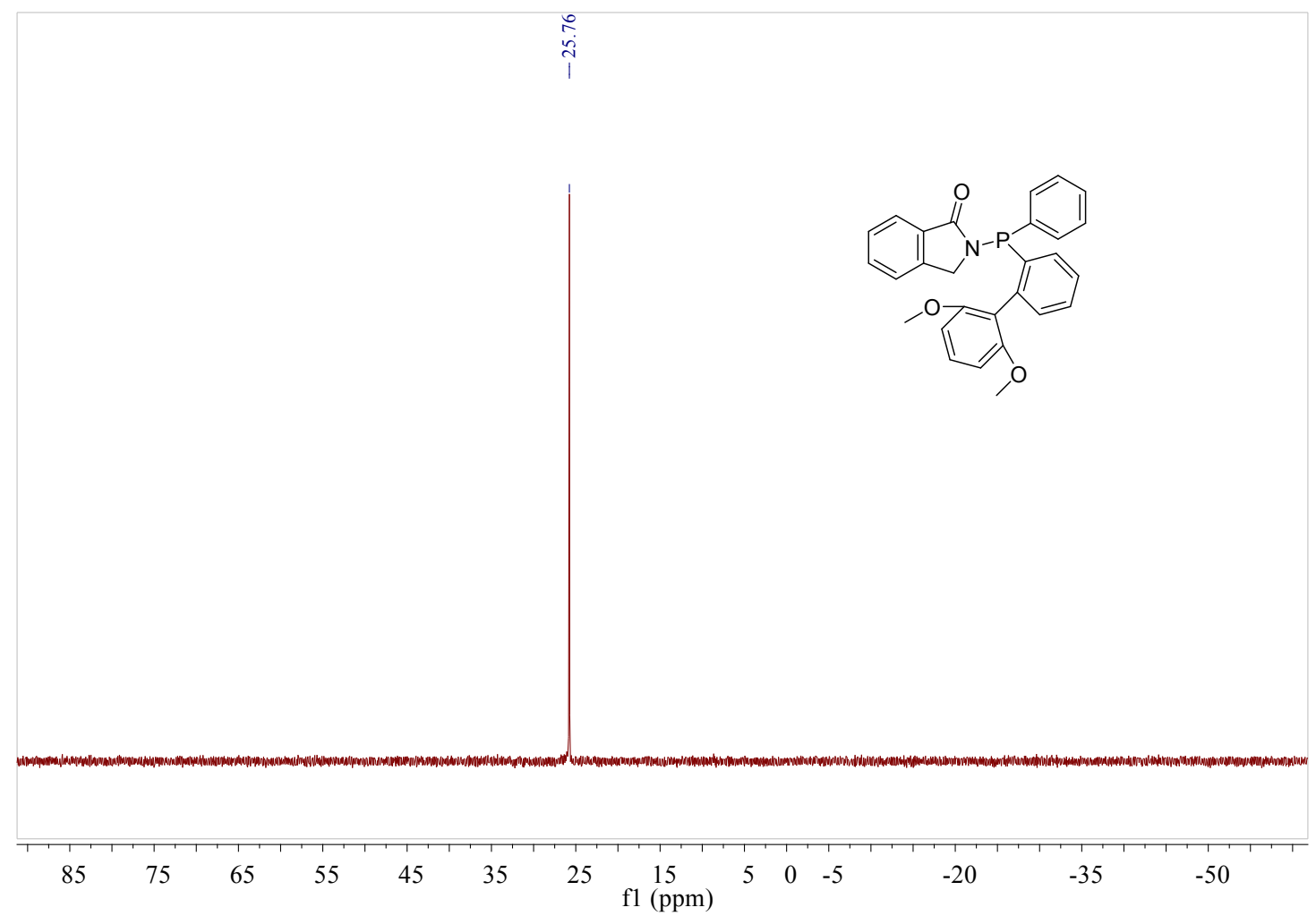

Figure S34. ${ }^{31} \mathrm{P}$ NMR spectrum $\left(\mathrm{CDCl}_{3}\right)$ of $\mathbf{L 9}$. 


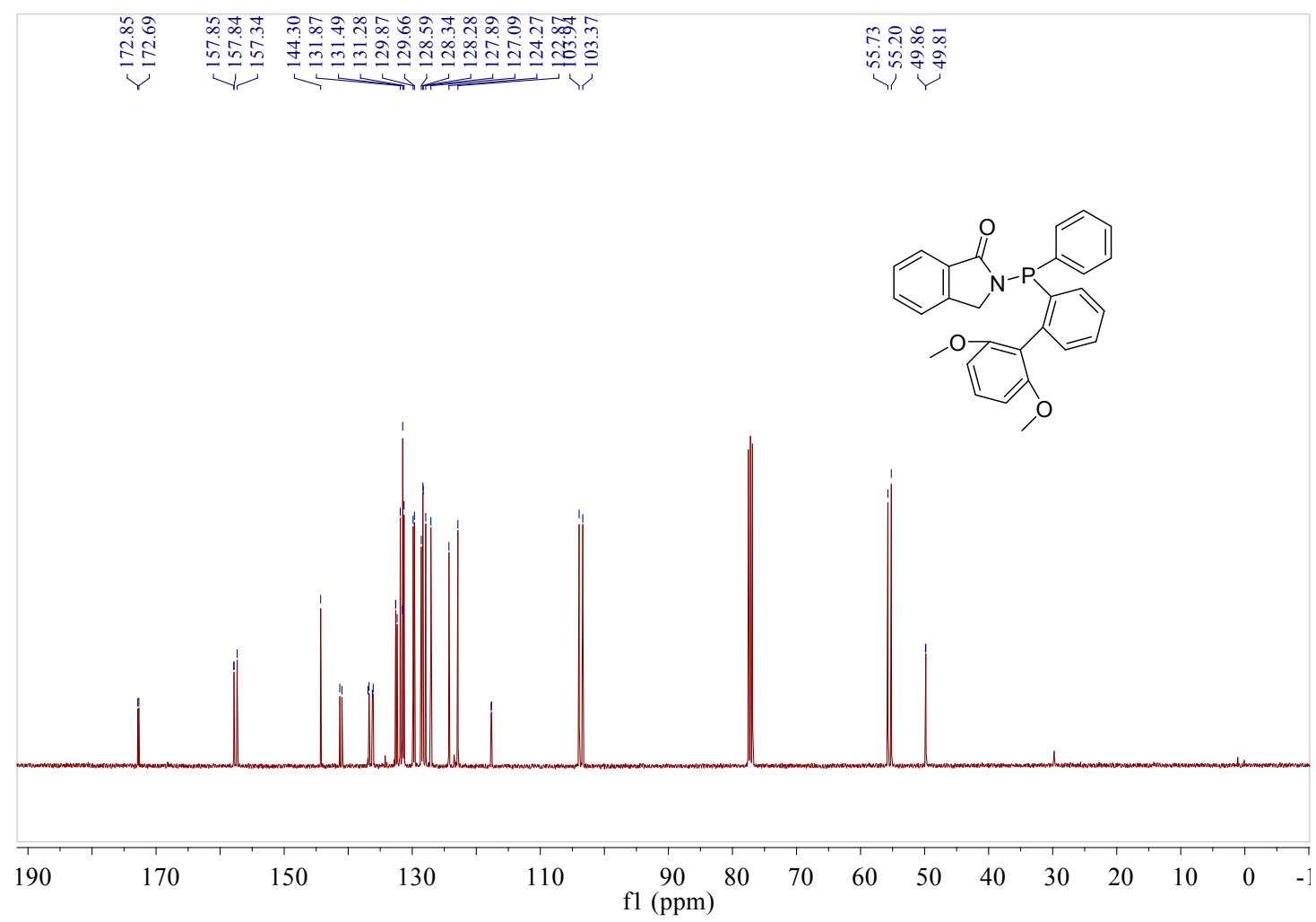

Figure $\mathbf{S 3 5} .{ }^{13} \mathrm{C}$ NMR spectrum in $\mathrm{CDCl}_{3}$ of $\mathbf{L 9}$.

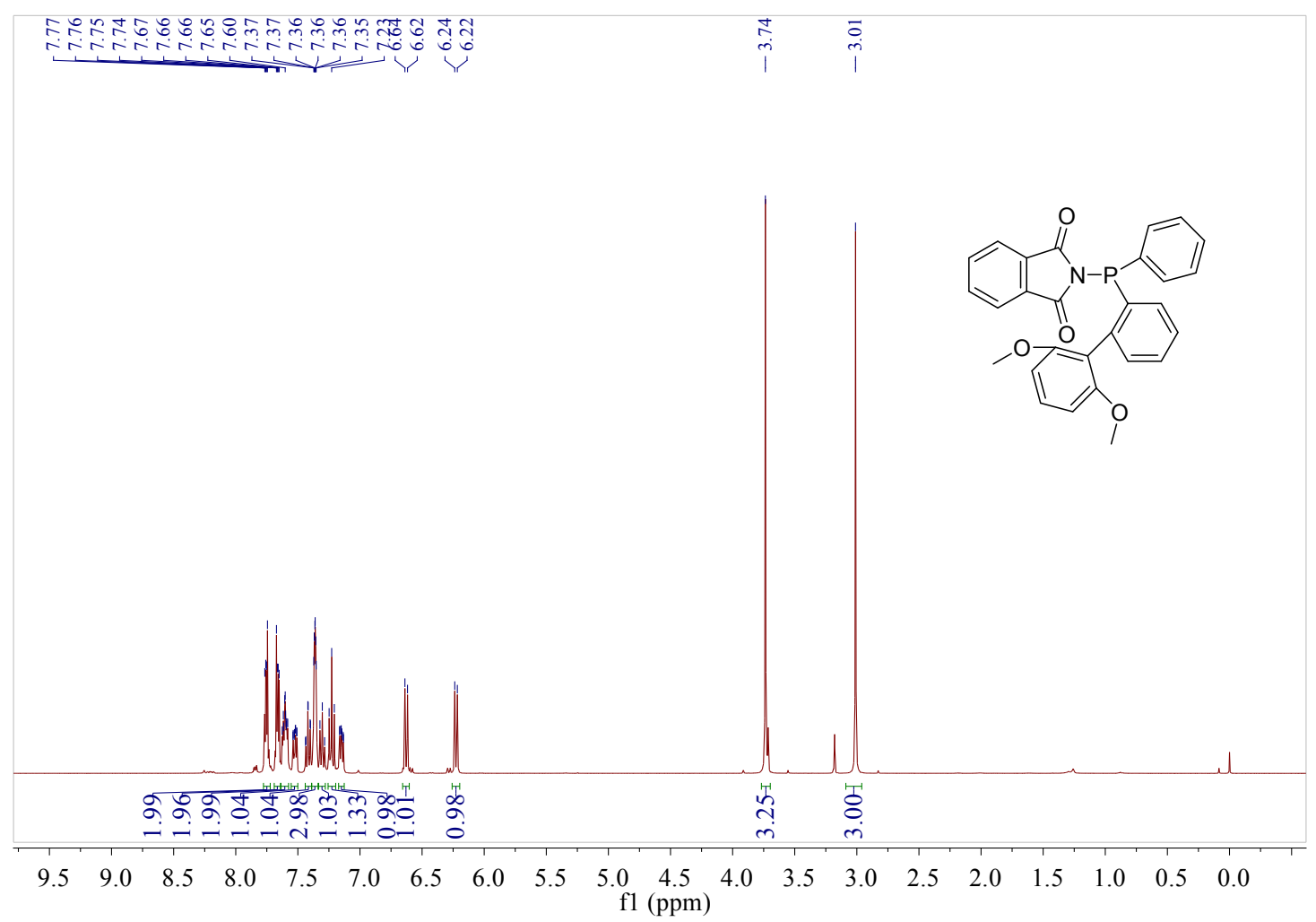

Figure S36. ${ }^{1} \mathrm{H}$ NMR spectrum $\left(400 \mathrm{MHz}, \mathrm{CDCl}_{3}\right)$ of $\mathbf{L 1 0}$. 


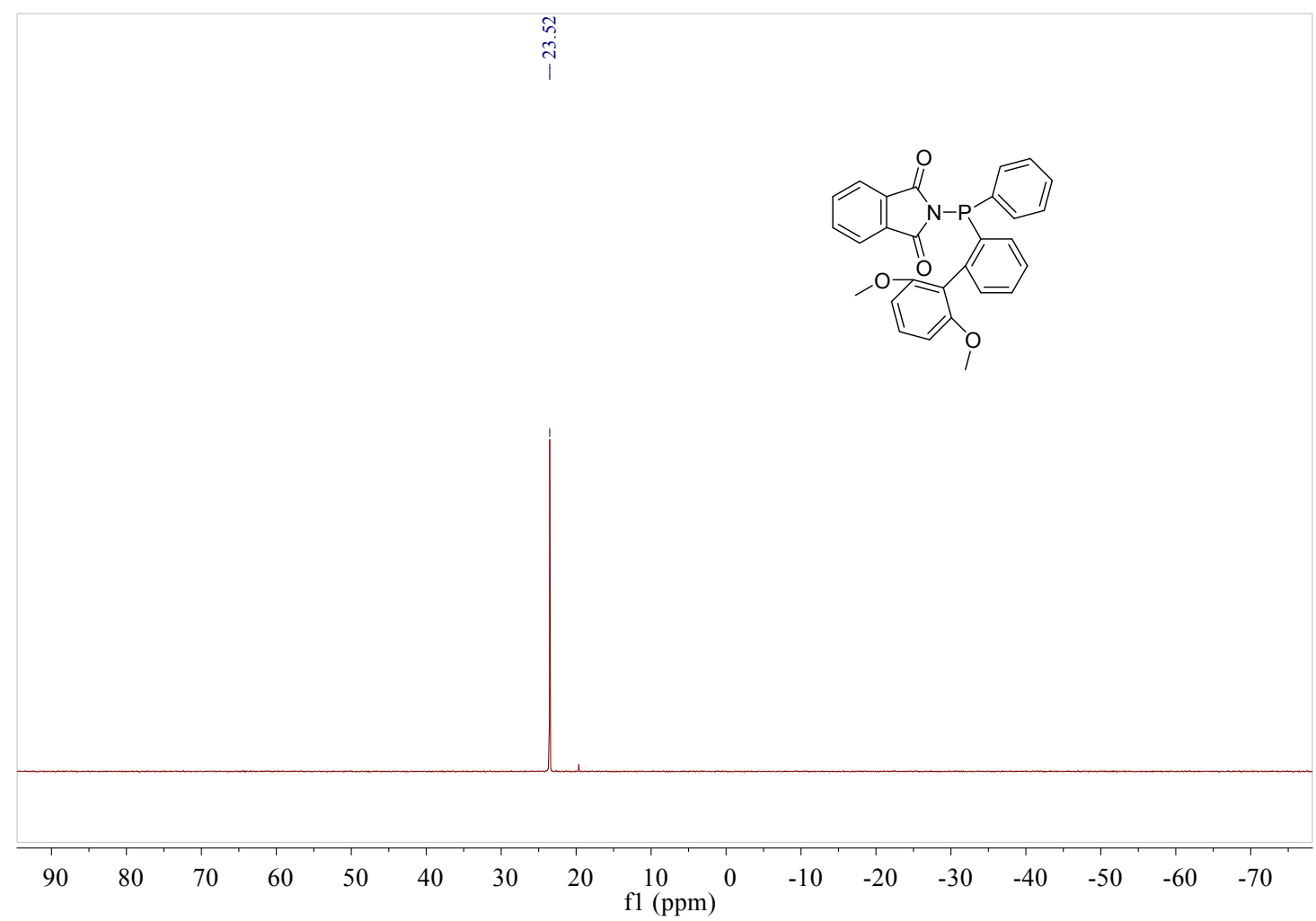

Figure S37. ${ }^{31} \mathrm{P}$ NMR spectrum $\left(\mathrm{CDCl}_{3}\right)$ of $\mathbf{L 1 0}$.

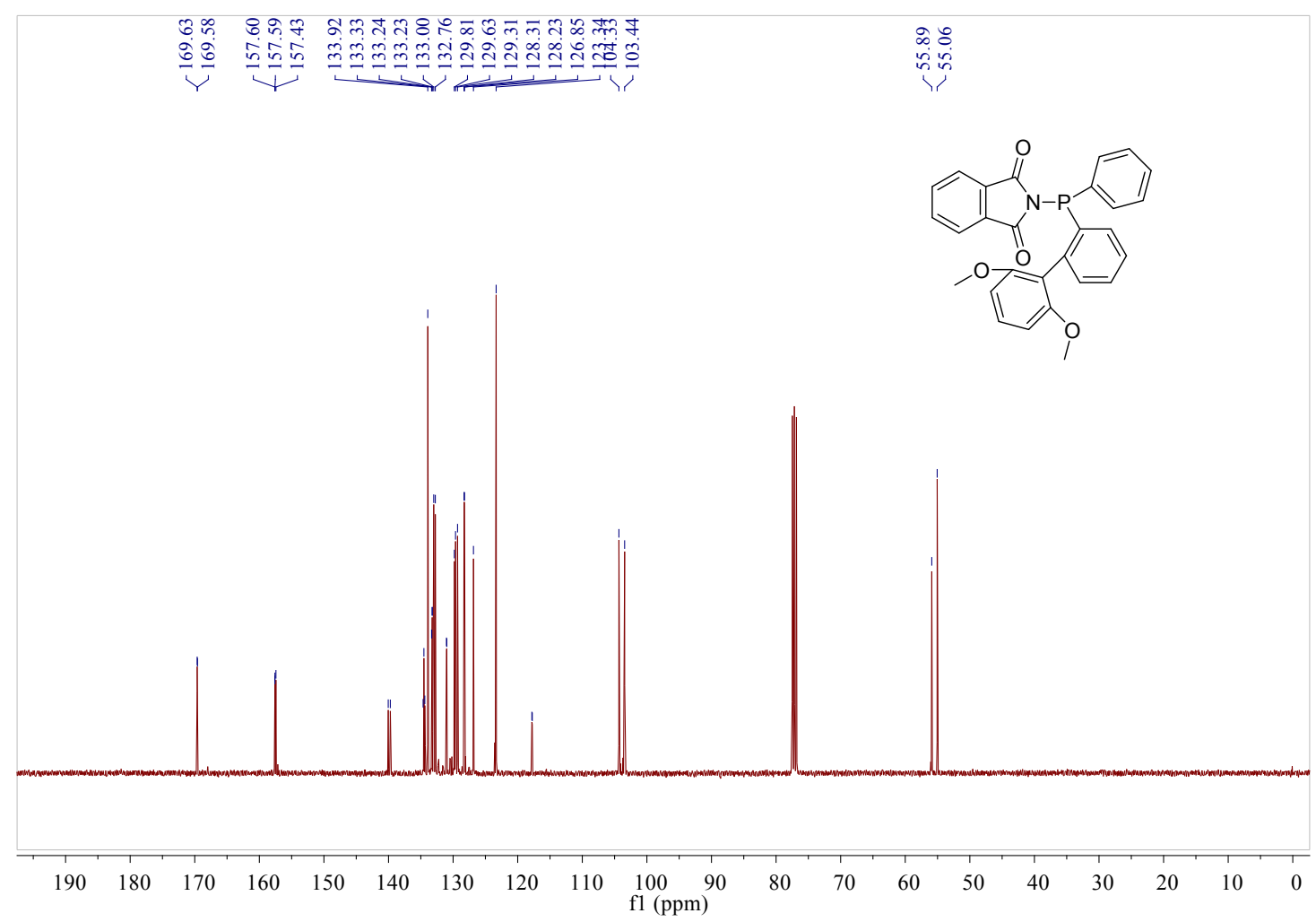

Figure S38. ${ }^{13} \mathrm{C}$ NMR spectrum in $\mathrm{CDCl}_{3}$ of $\mathbf{L 1 0}$. 


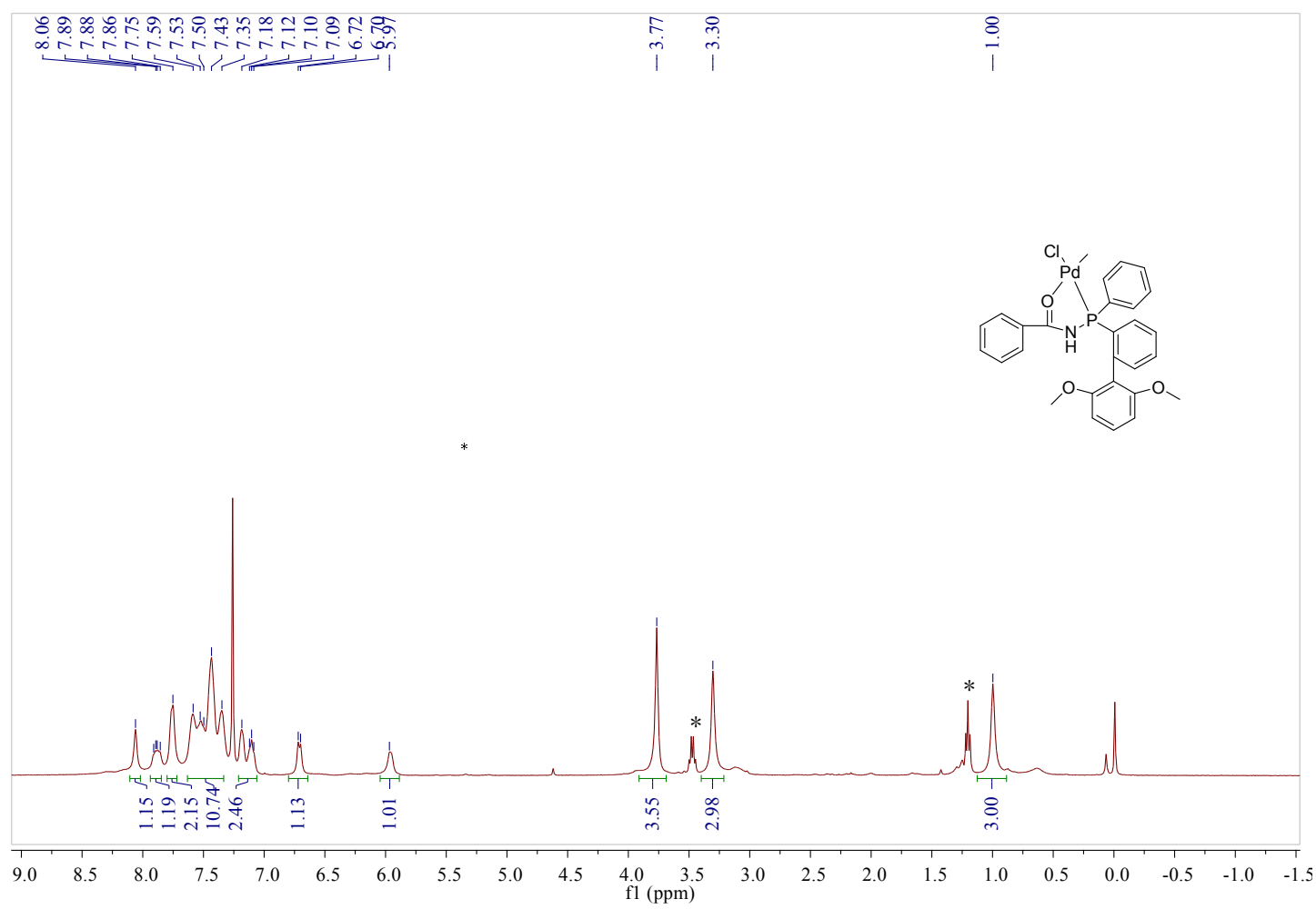

Figure S39. ${ }^{1} \mathrm{H}$ NMR spectrum ( $400 \mathrm{MHz}, \mathrm{CDCl}_{3}$ ) of Pd1. ${ }^{*} \mathrm{Et}_{2} \mathrm{O}$.

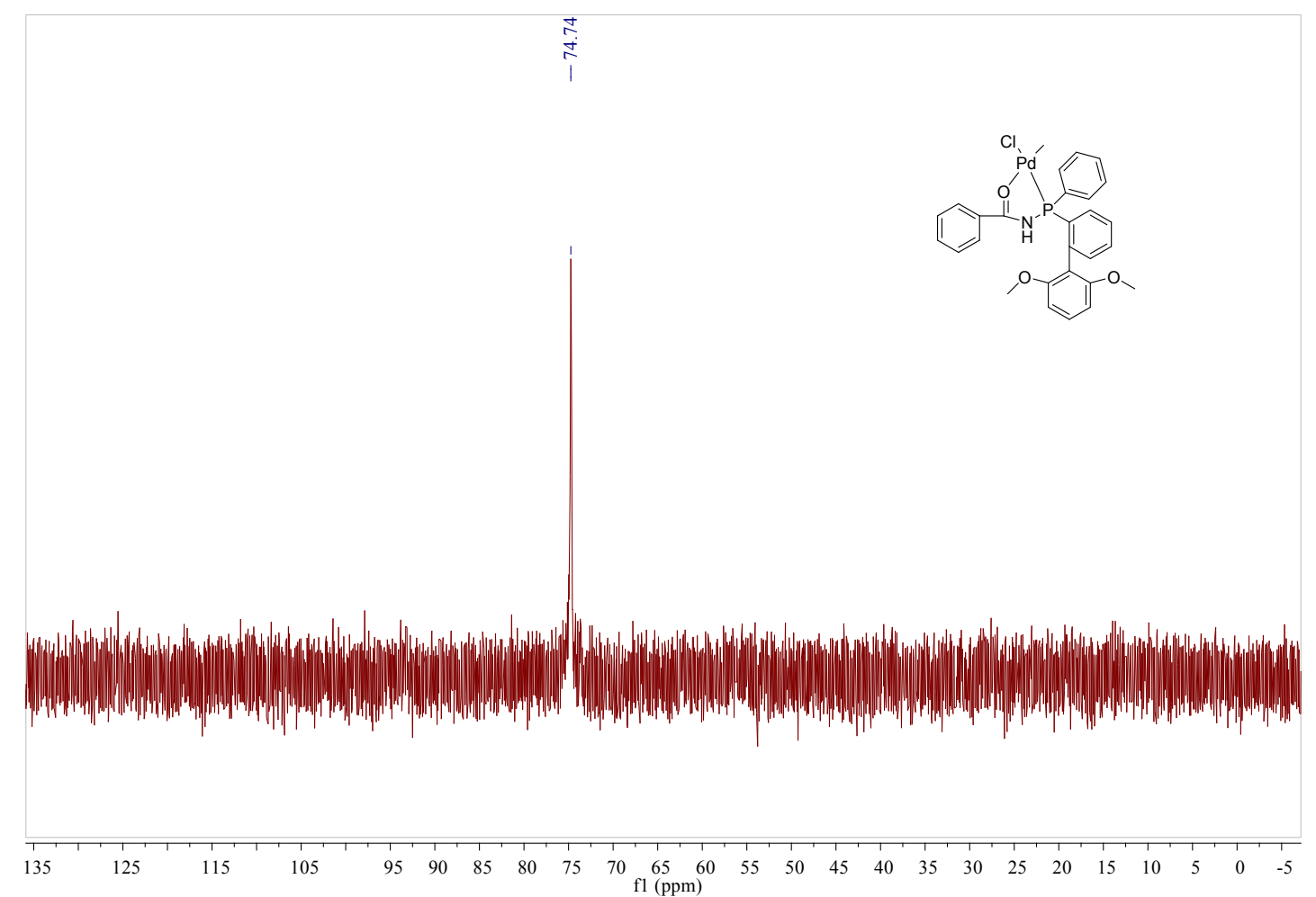

Figure S40. ${ }^{31} \mathrm{P}$ NMR spectrum $\left(\mathrm{CDCl}_{3}\right)$ of Pd1. 


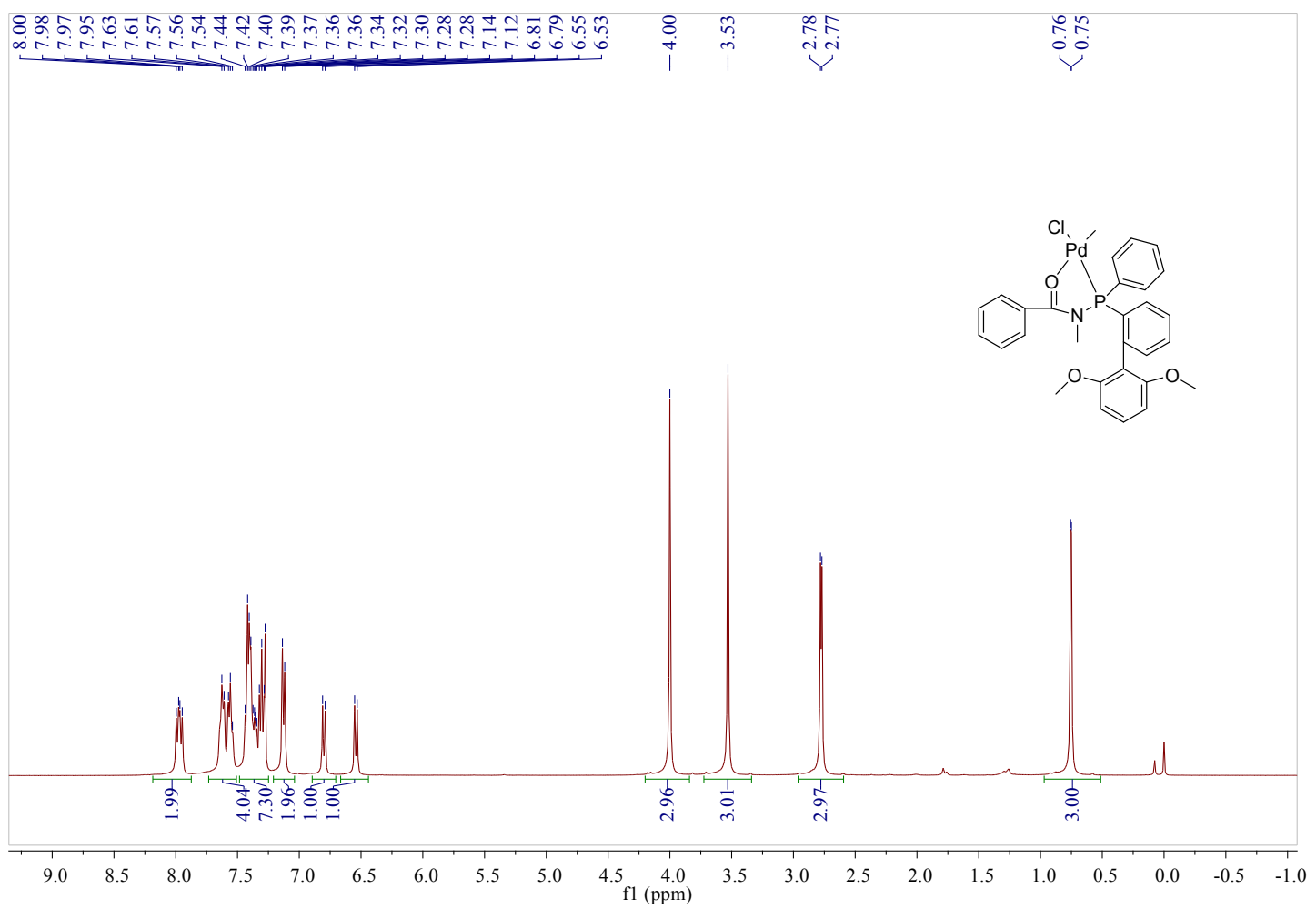

Figure S41. ${ }^{1} \mathrm{H}$ NMR spectrum $\left(400 \mathrm{MHz}, \mathrm{CDCl}_{3}\right.$ ) of $\mathbf{P d 2}$.

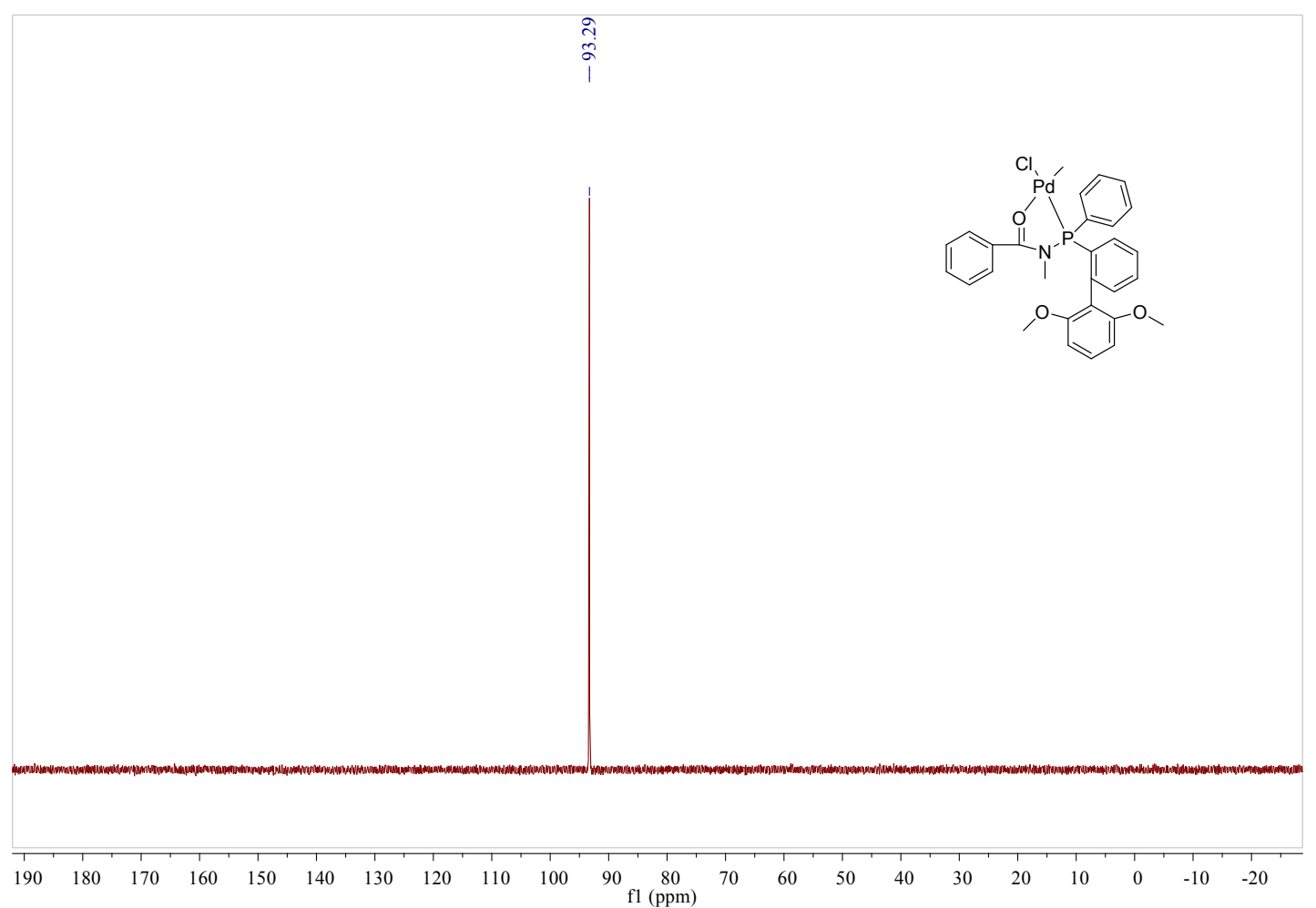

Figure S42. ${ }^{31} \mathrm{P}$ NMR spectrum $\left(\mathrm{CDCl}_{3}\right)$ of $\mathbf{P d 2}$. 


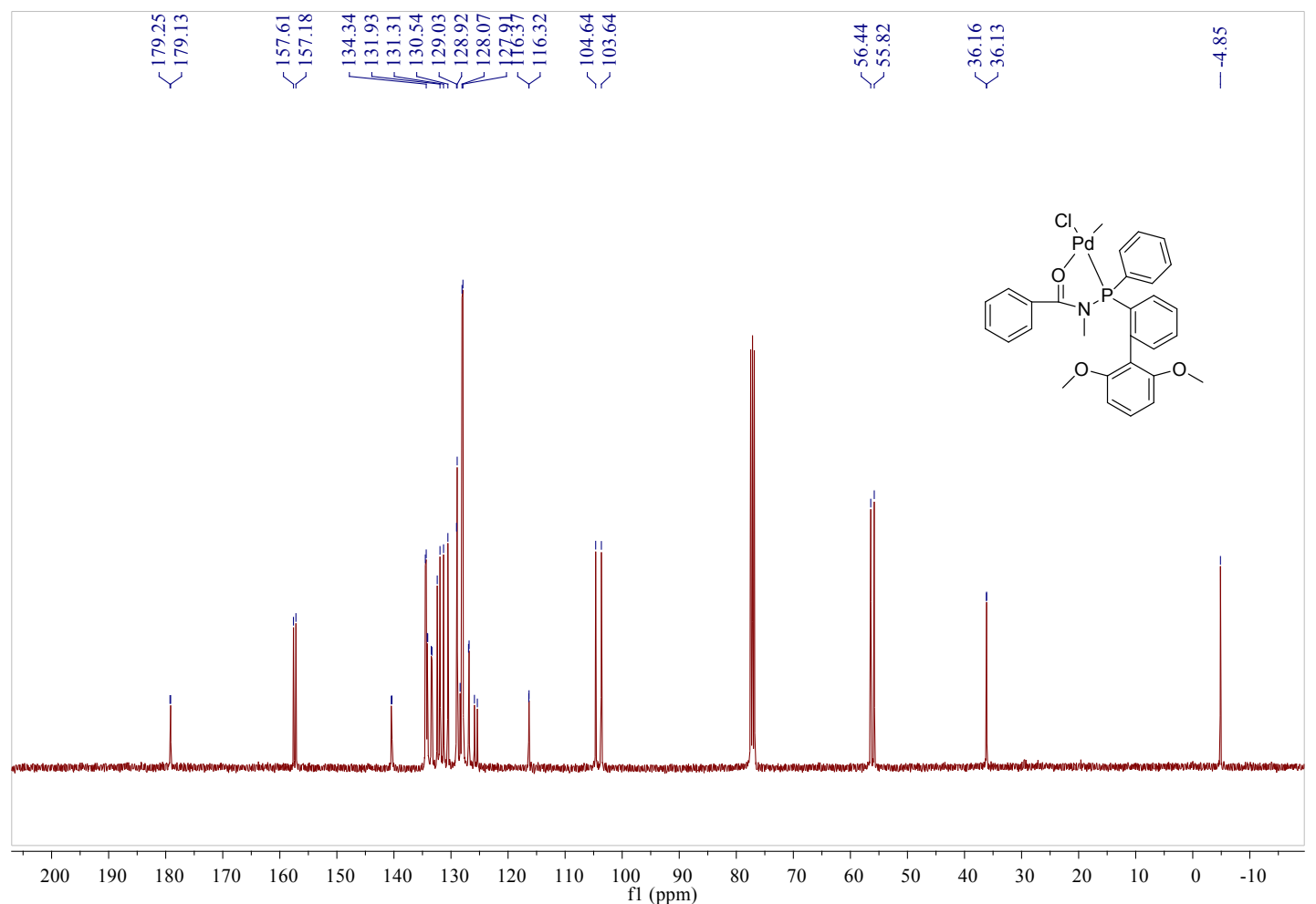

Figure S43. ${ }^{13} \mathrm{C}$ NMR spectrum in $\mathrm{CDCl}_{3}$ of $\mathbf{P d 2}$.

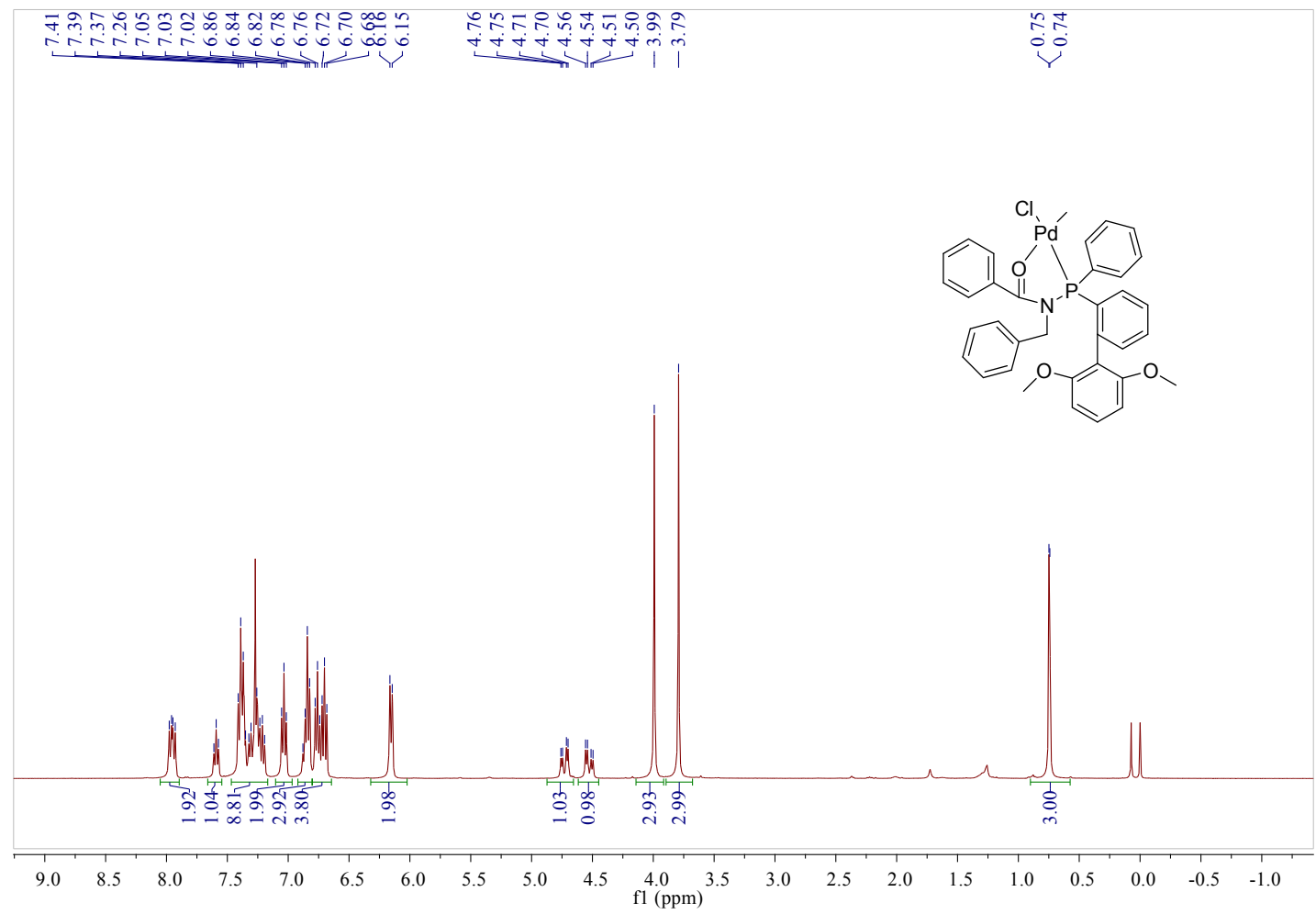

Figure S44. ${ }^{1} \mathrm{H}$ NMR spectrum $\left(400 \mathrm{MHz}, \mathrm{CDCl}_{3}\right)$ of $\mathbf{P d 3}$. 


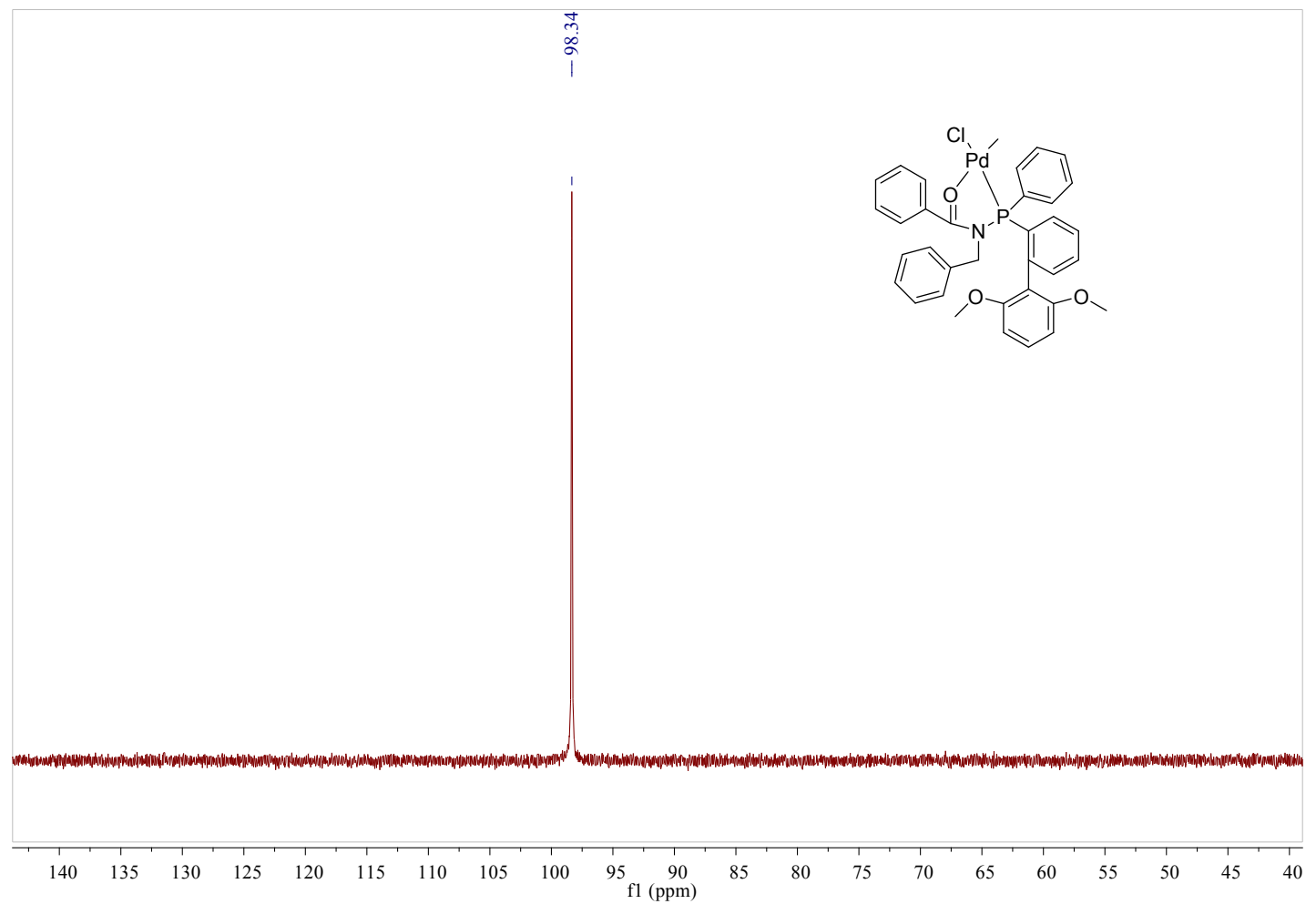

Figure S45. ${ }^{31} \mathrm{P}$ NMR spectrum $\left(\mathrm{CDCl}_{3}\right)$ of $\mathbf{P d 3}$.

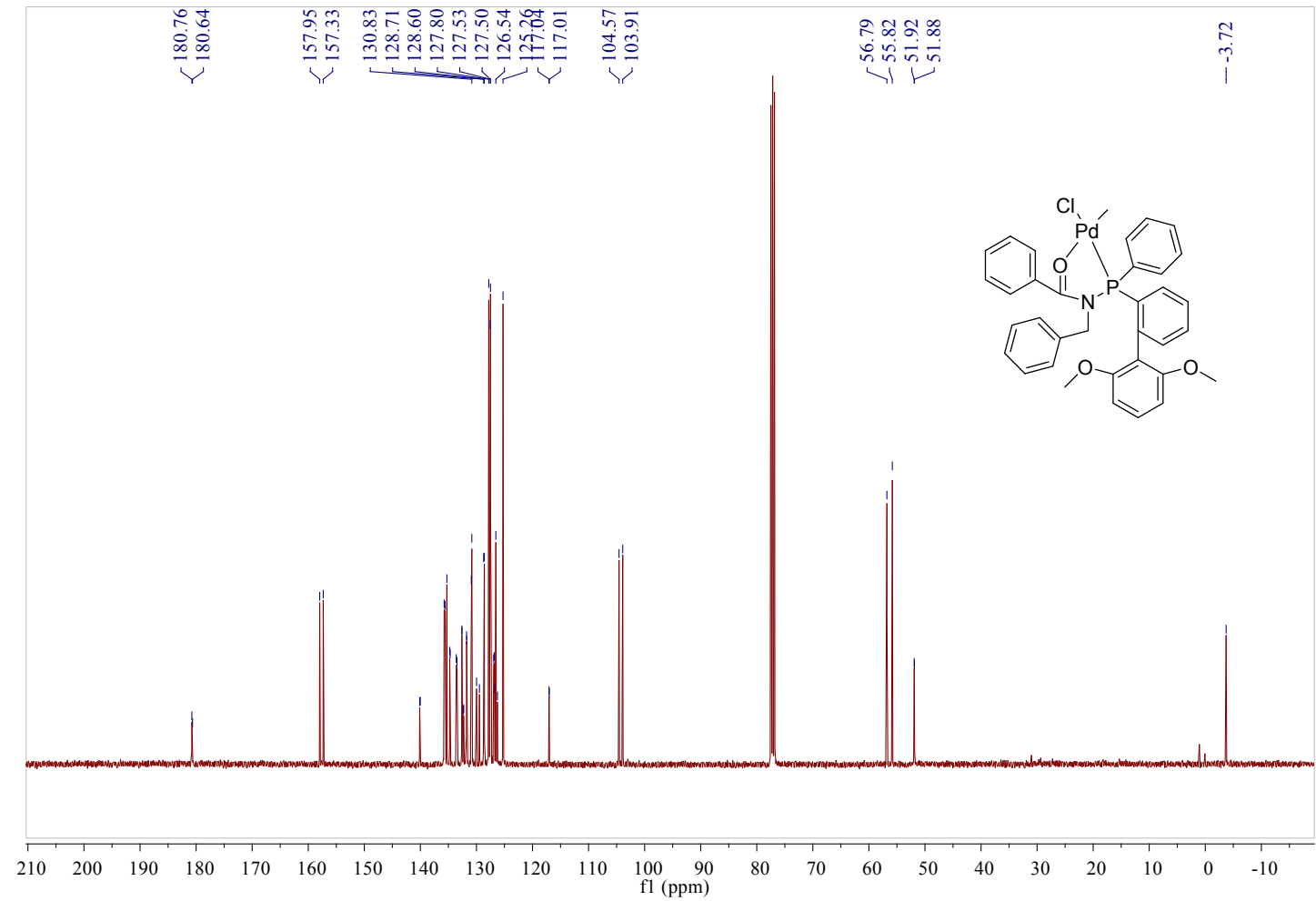

Figure S46. ${ }^{13} \mathrm{C}$ NMR spectrum in $\mathrm{CDCl}_{3}$ of $\mathbf{P d 3}$. 


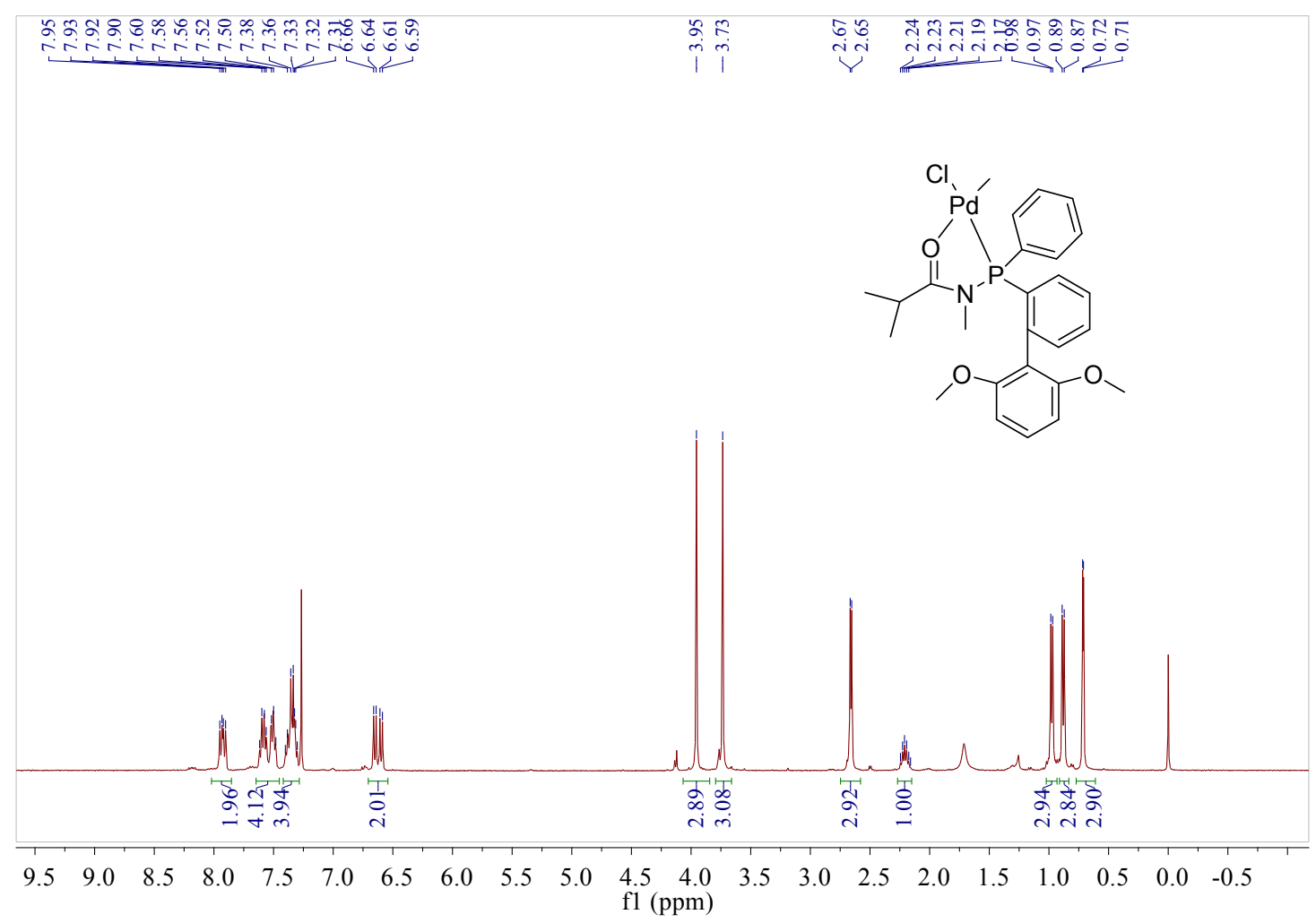

Figure S47. ${ }^{1} \mathrm{H}$ NMR spectrum ( $400 \mathrm{MHz}, \mathrm{CDCl}_{3}$ ) of $\mathbf{P d 4}$.

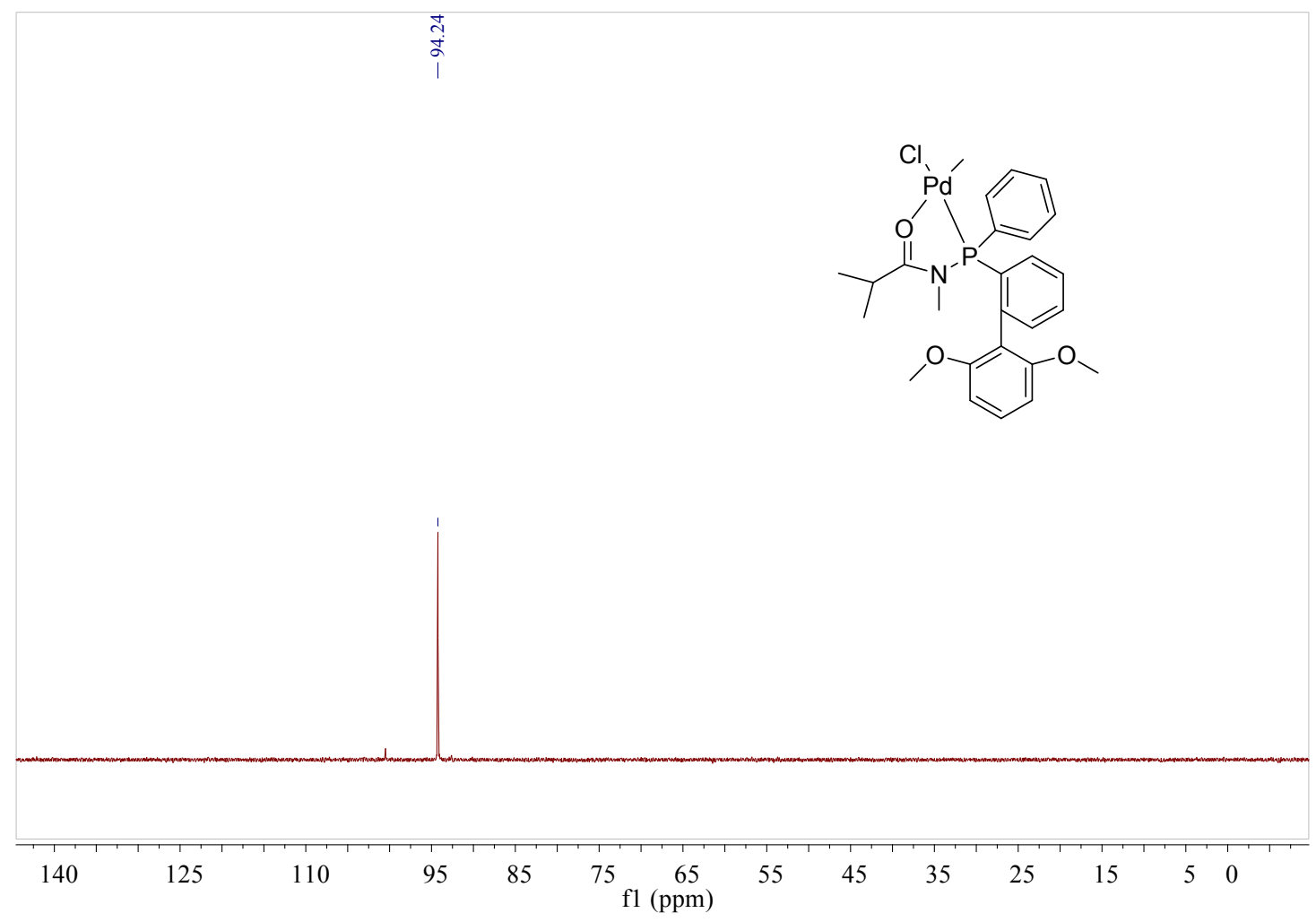

Figure S48. ${ }^{31} \mathrm{P}$ NMR spectrum $\left(\mathrm{CDCl}_{3}\right)$ of $\mathbf{P d 4}$. 


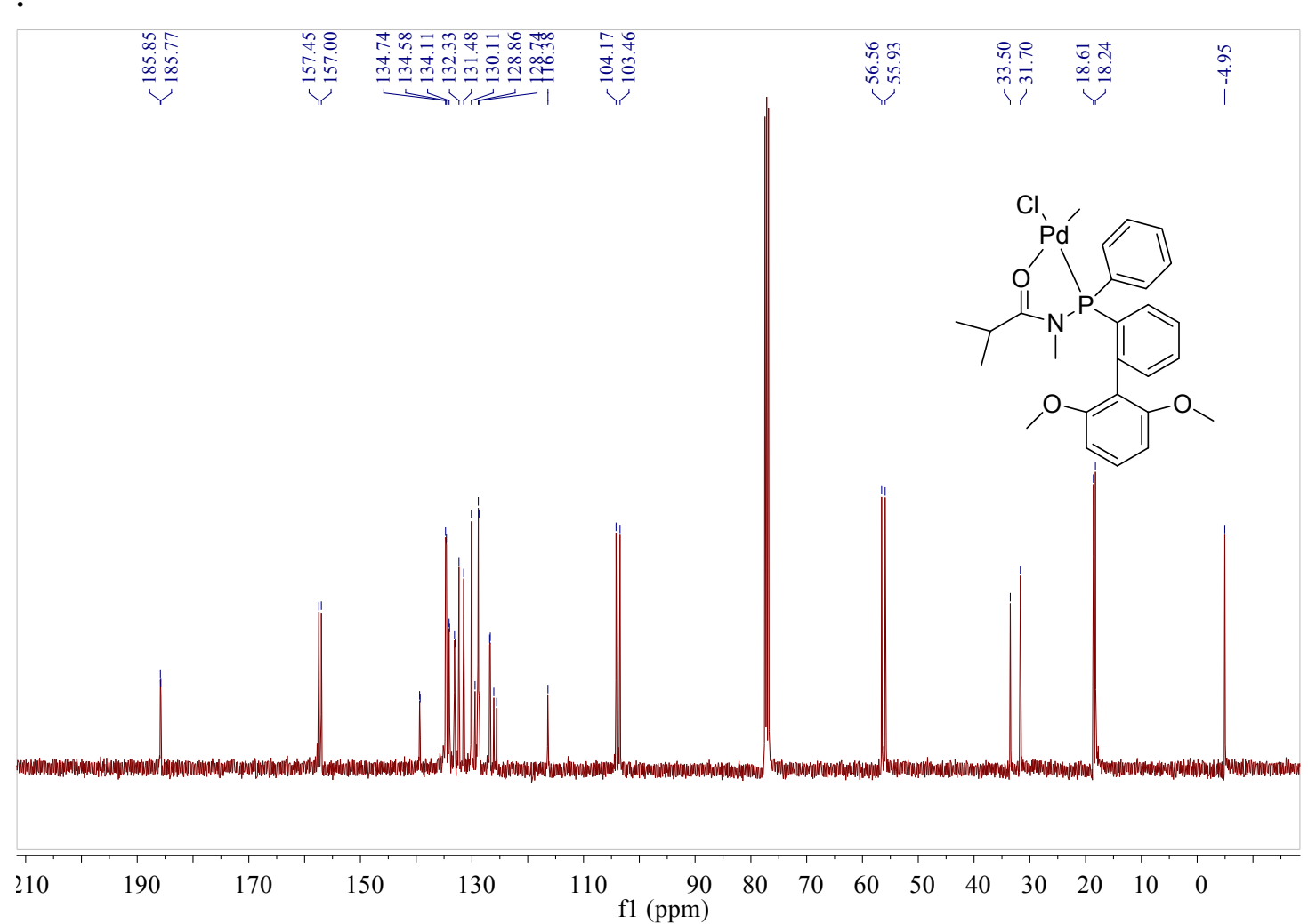

Figure S49. ${ }^{13} \mathrm{C}$ NMR spectrum in $\mathrm{CDCl}_{3}$ of $\mathbf{P d 4}$.

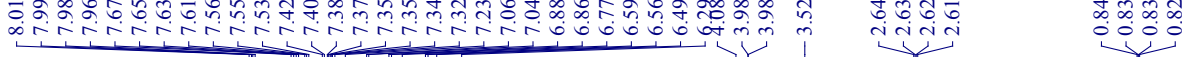

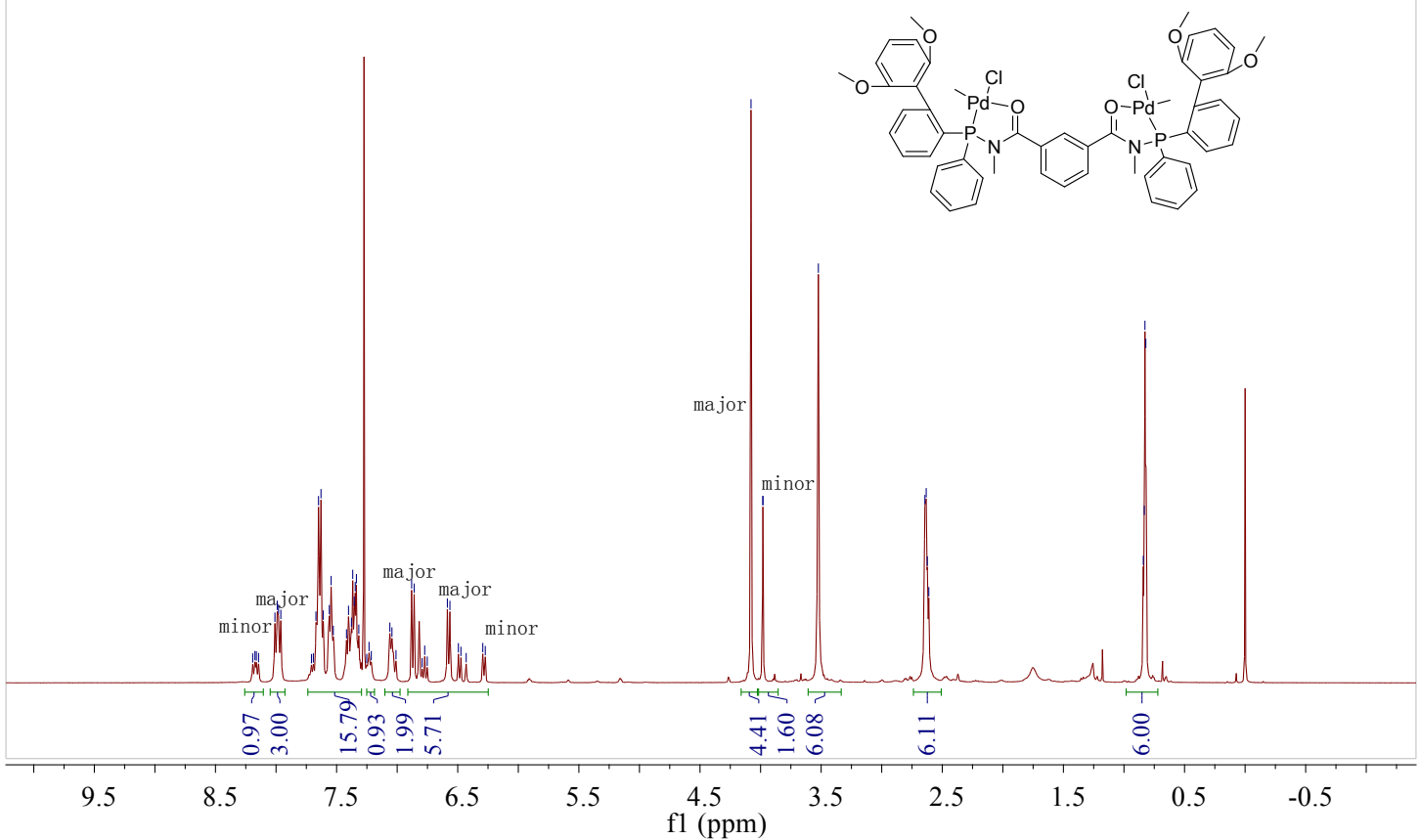

Figure S50. ${ }^{1} \mathrm{H}$ NMR spectrum ( $400 \mathrm{MHz}, \mathrm{CDCl}_{3}$ ) of Pd5. 


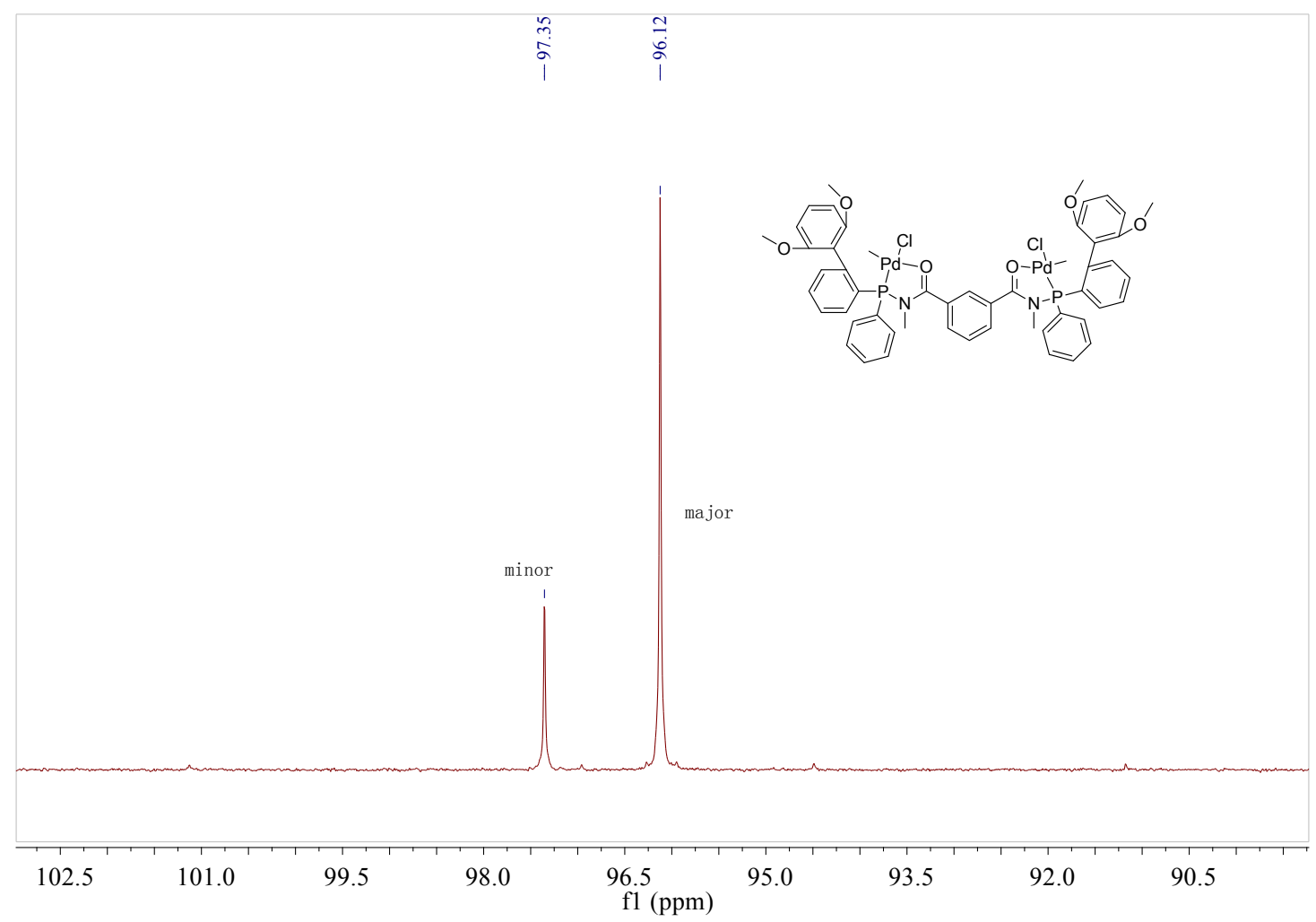

Figure S51. ${ }^{31} \mathrm{P}$ NMR spectrum $\left(\mathrm{CDCl}_{3}\right)$ of Pd5.
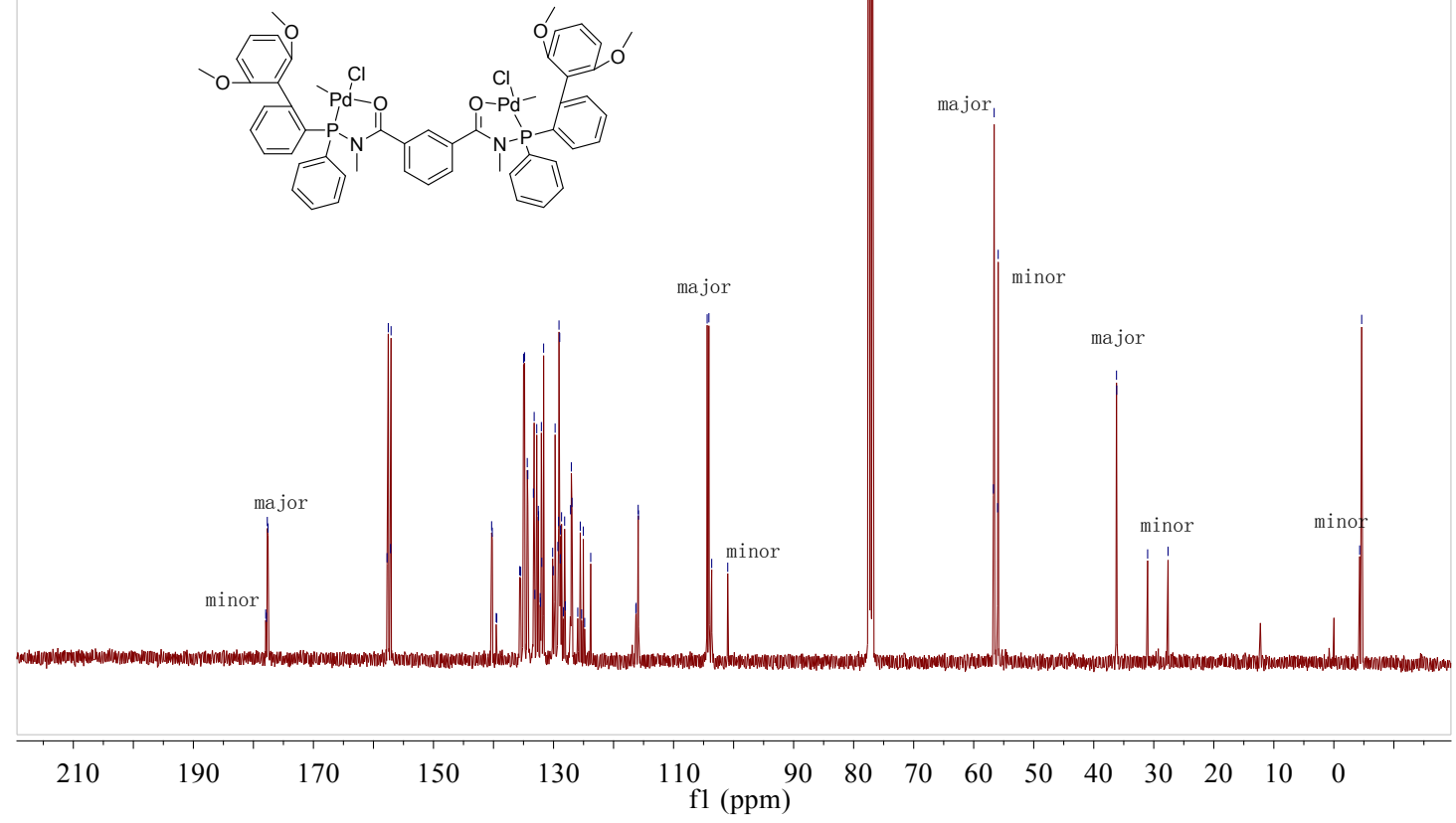

Figure S52. ${ }^{13} \mathrm{C}$ NMR spectrum in $\mathrm{CDCl}_{3}$ of $\mathbf{P d 5}$. 


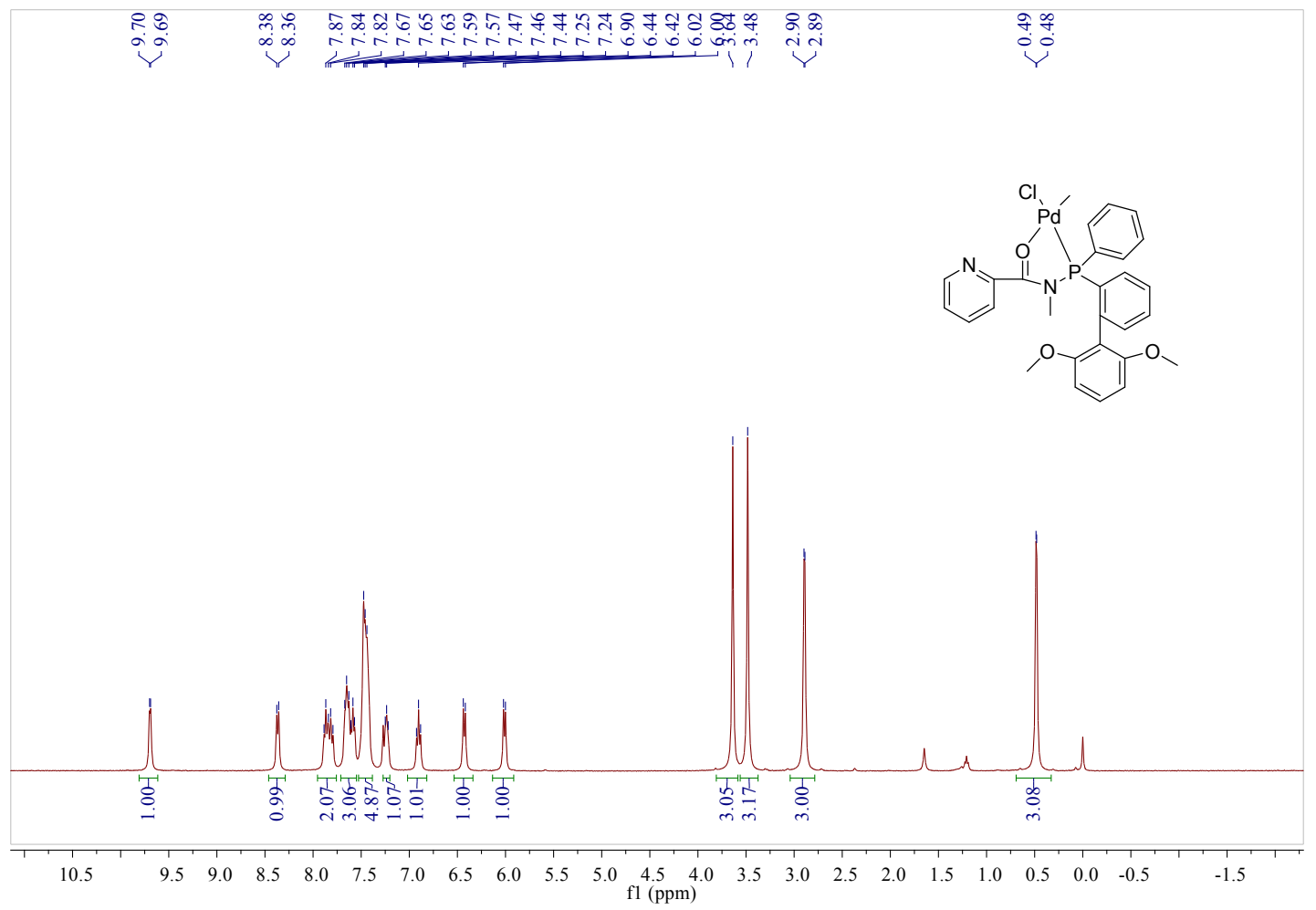

Figure S53. ${ }^{1} \mathrm{H}$ NMR spectrum $\left(400 \mathrm{MHz}, \mathrm{CDCl}_{3}\right)$ of $\mathbf{P d 6}$.

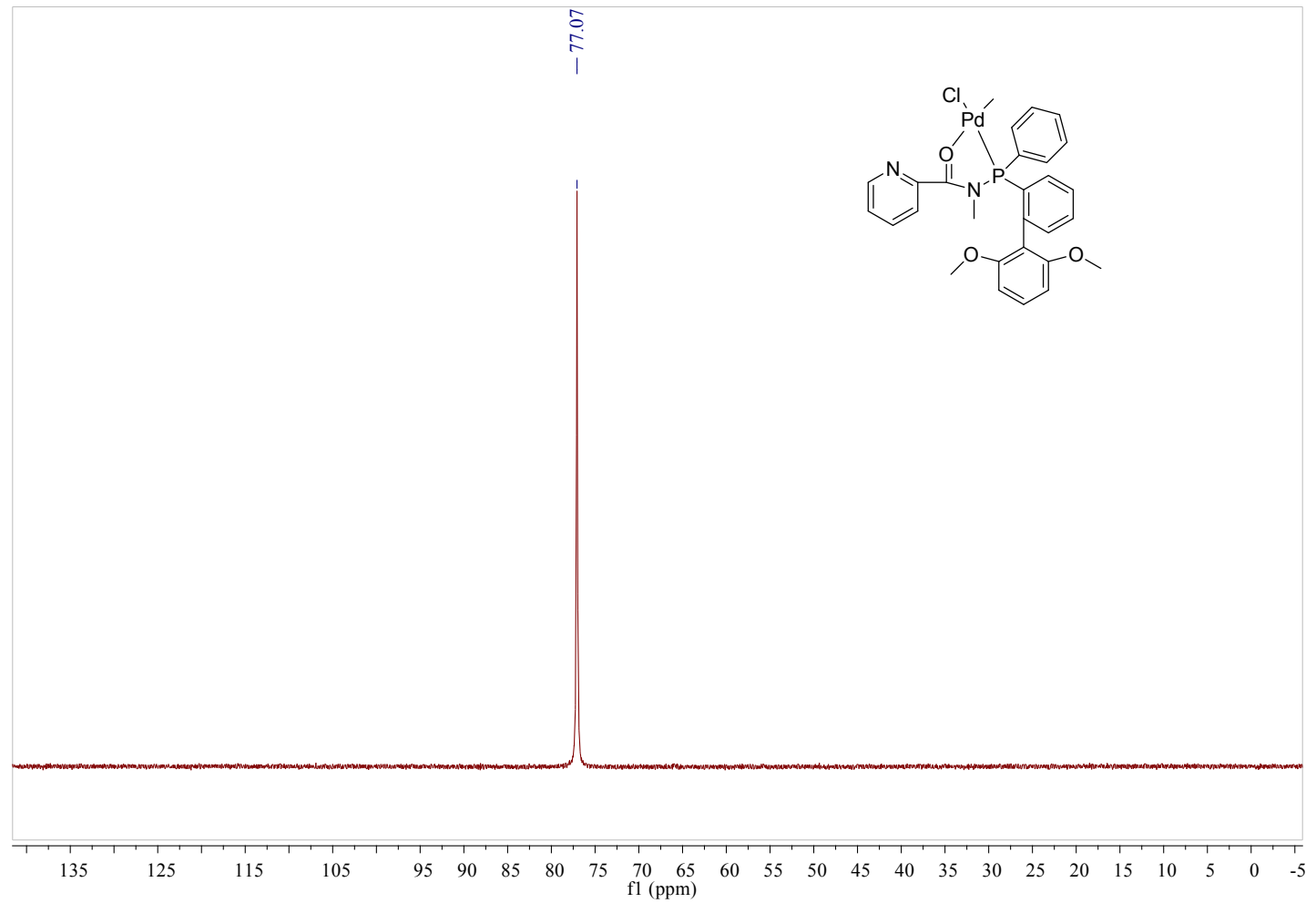

Figure S54. ${ }^{31} \mathrm{P}$ NMR spectrum $\left(\mathrm{CDCl}_{3}\right)$ of Pd6. 


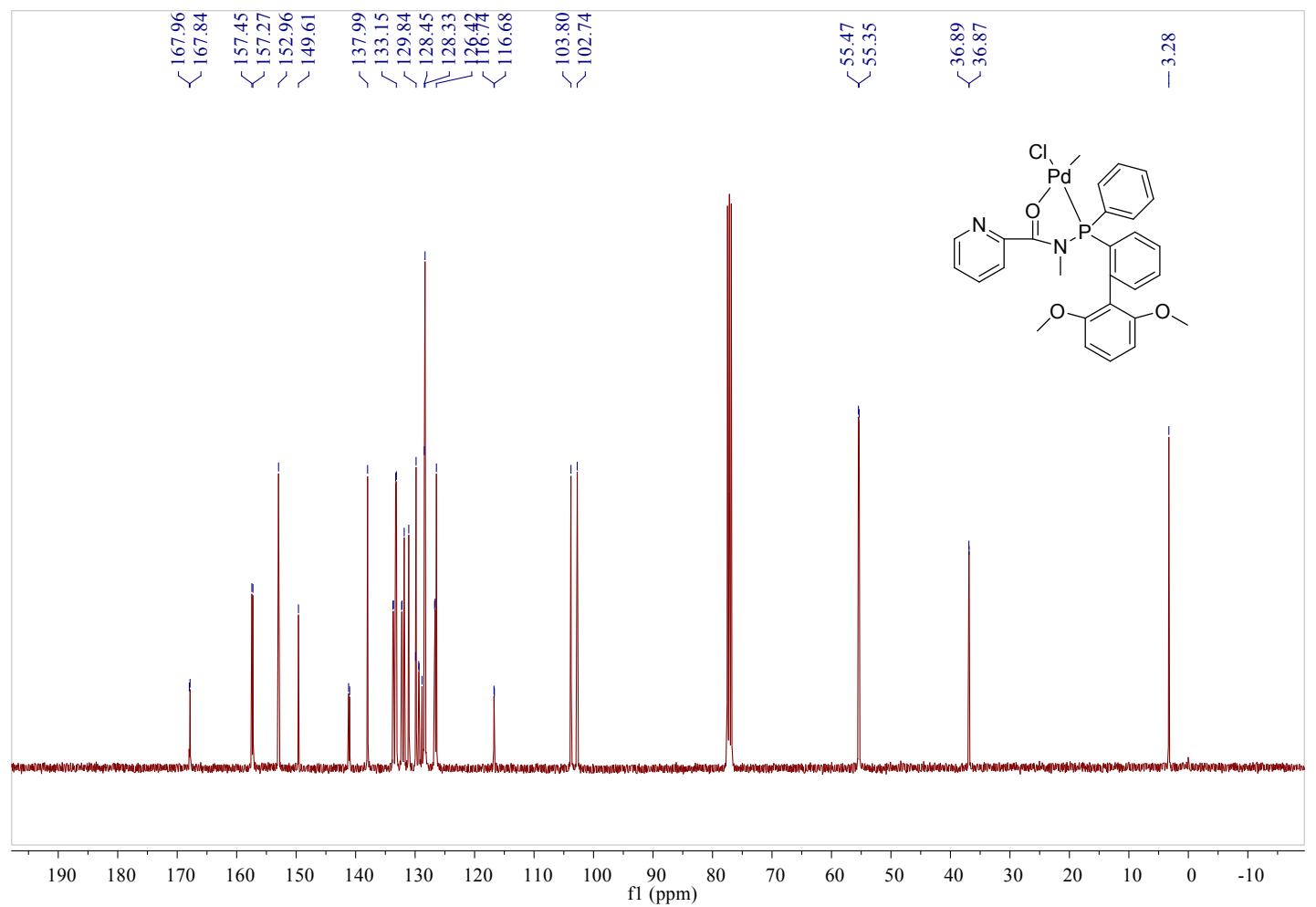

Figure S55. ${ }^{13} \mathrm{C}$ NMR spectrum in $\mathrm{CDCl}_{3}$ of $\mathbf{P d 6}$.

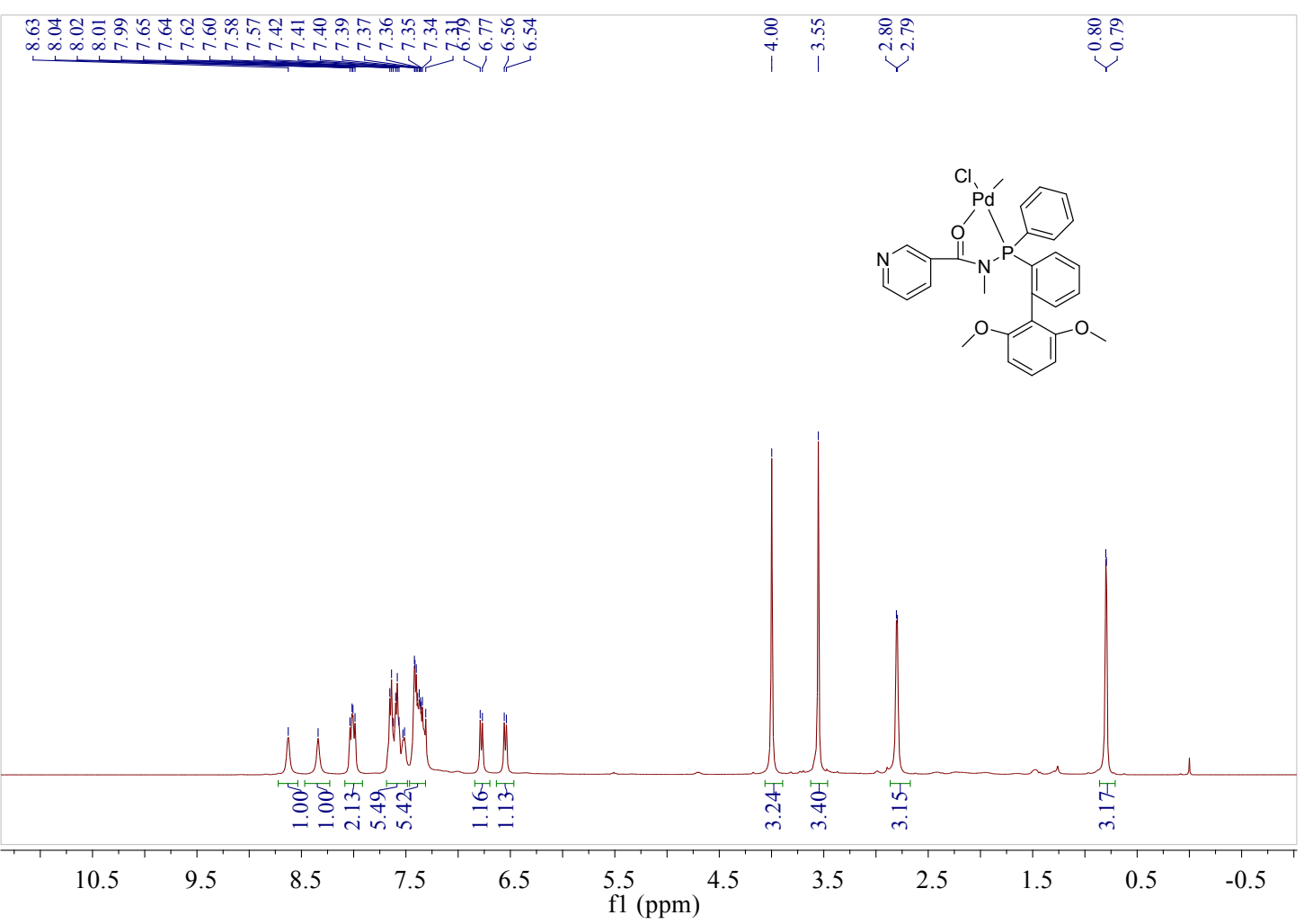

Figure S56. ${ }^{1} \mathrm{H}$ NMR spectrum $\left(400 \mathrm{MHz}, \mathrm{CDCl}_{3}\right.$ ) of $\mathbf{P d} 7$. 


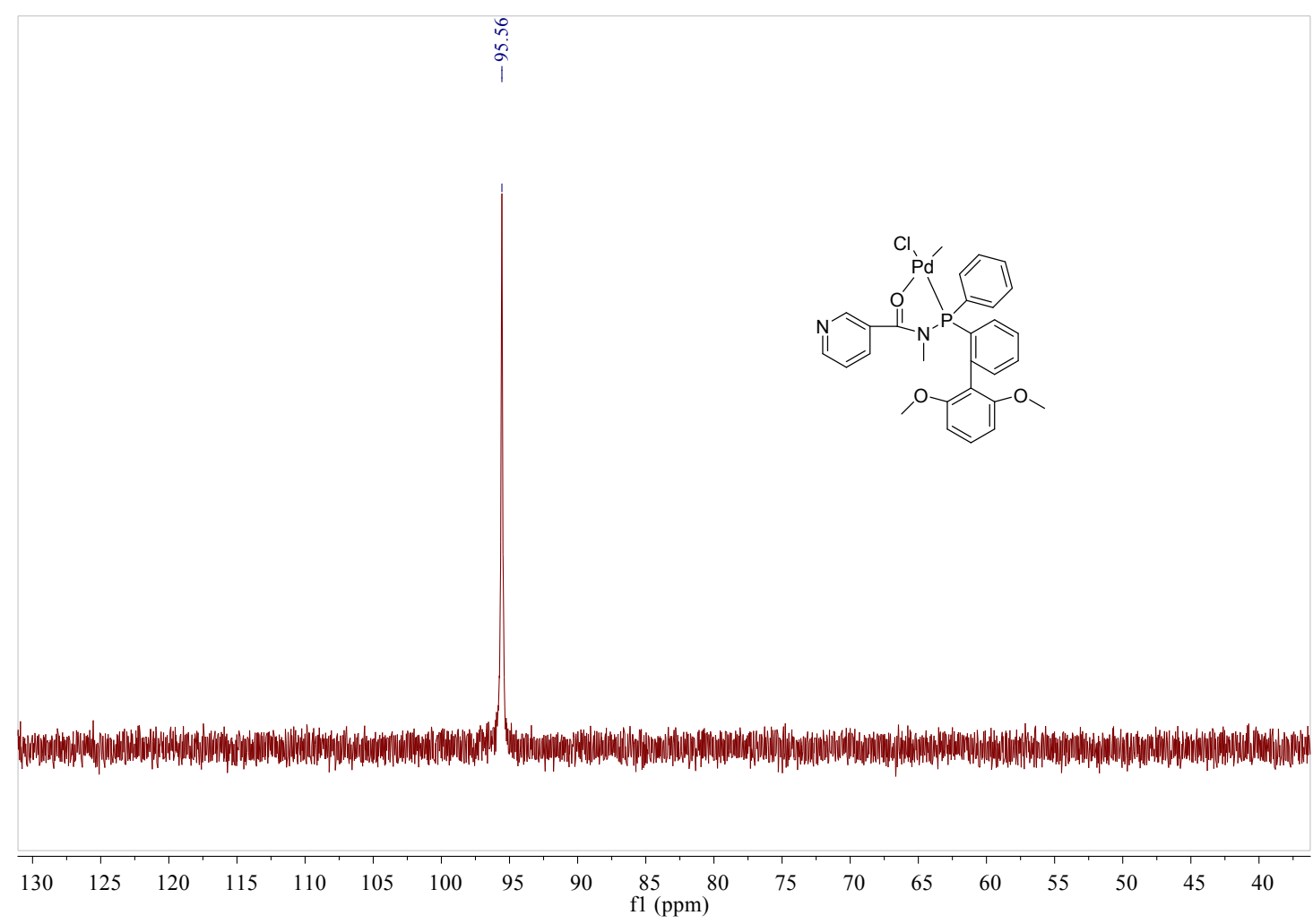

Figure S57. ${ }^{31} \mathrm{P}$ NMR spectrum $\left(\mathrm{CDCl}_{3}\right)$ of $\mathbf{P d}$.

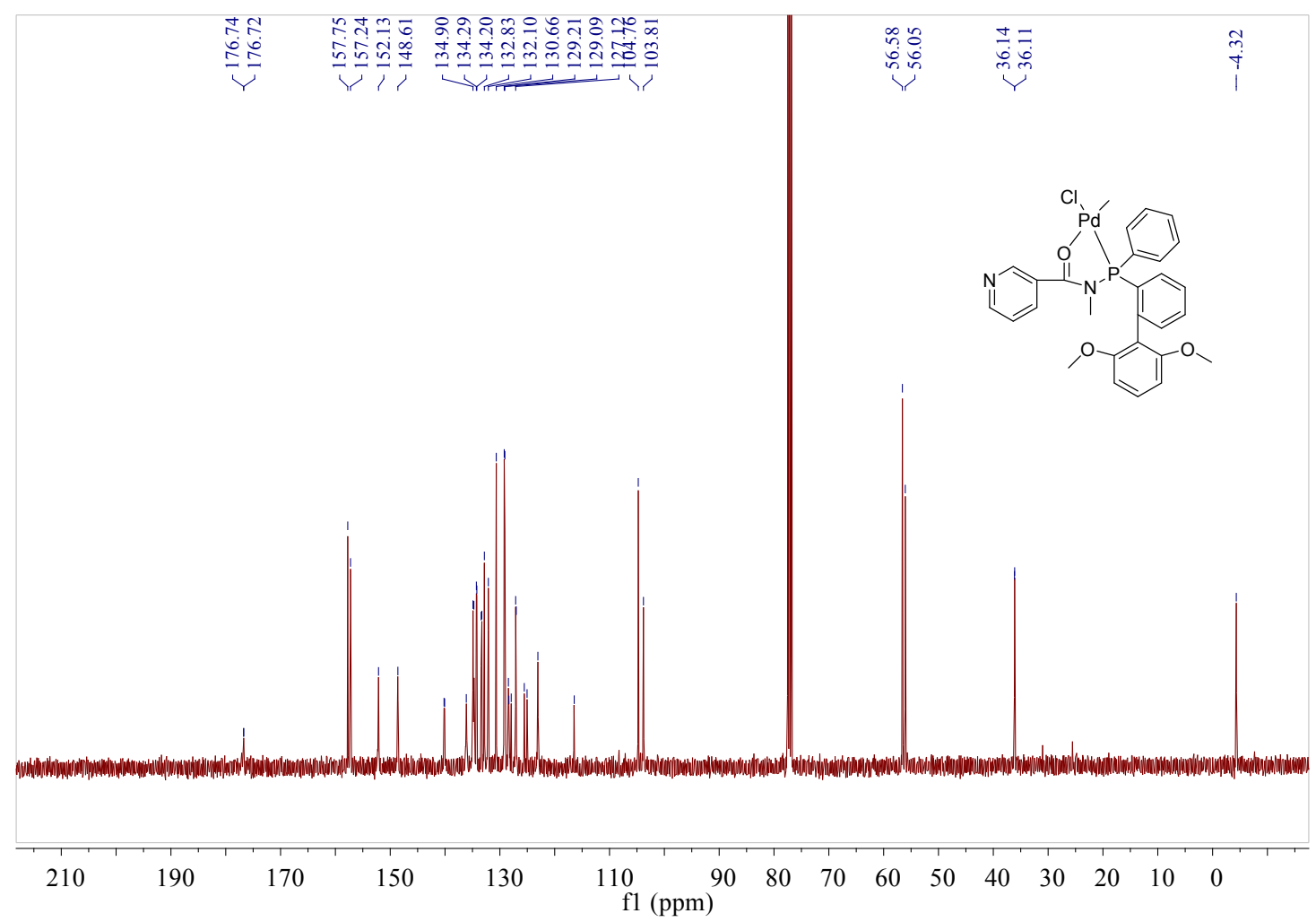

Figure S58. ${ }^{13} \mathrm{C}$ NMR spectrum in $\mathrm{CDCl}_{3}$ of $\mathbf{P d 7}$. 


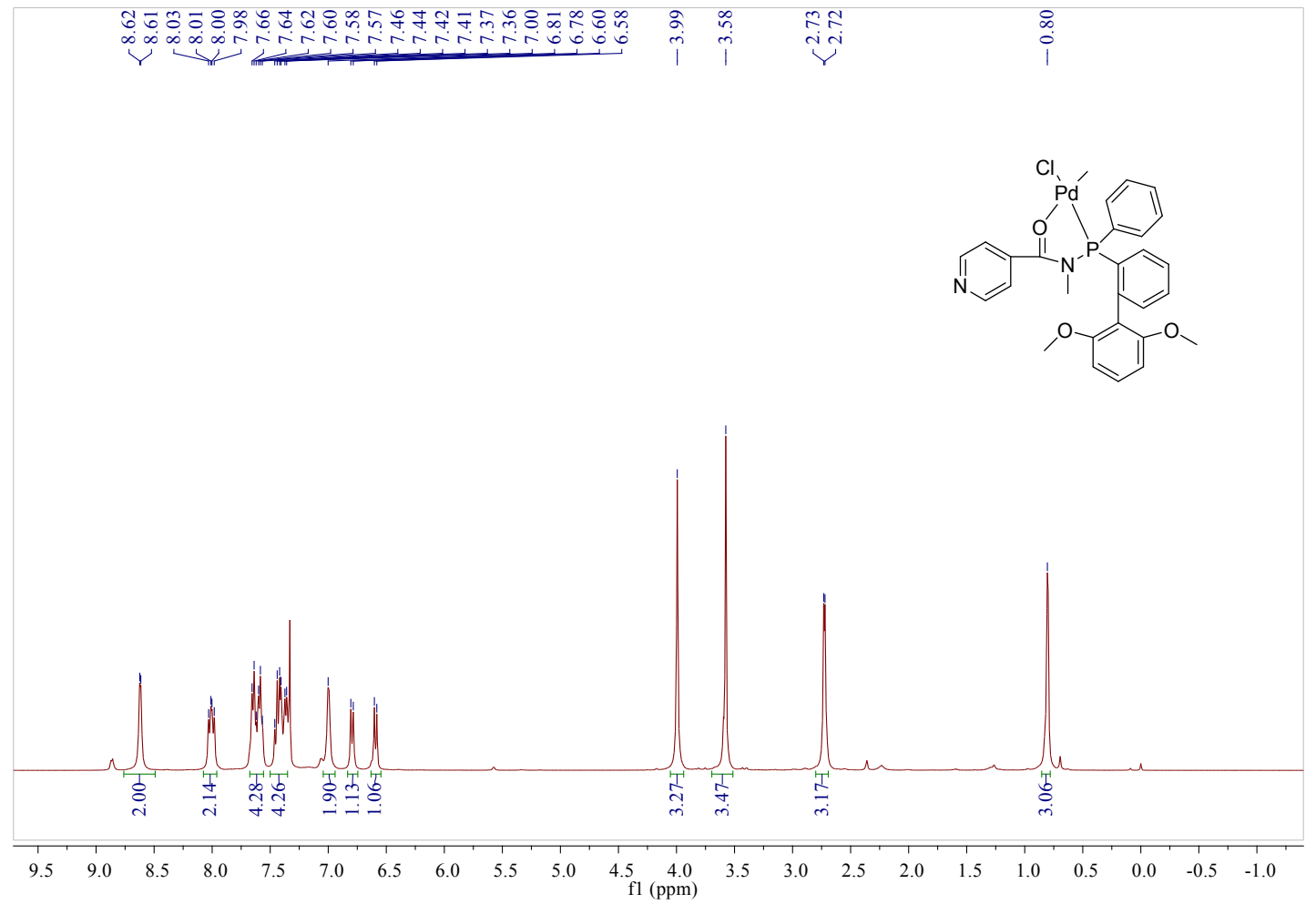

Figure S59. ${ }^{1} \mathrm{H}$ NMR spectrum $\left(400 \mathrm{MHz}, \mathrm{CDCl}_{3}\right)$ of $\mathbf{P d 8}$.

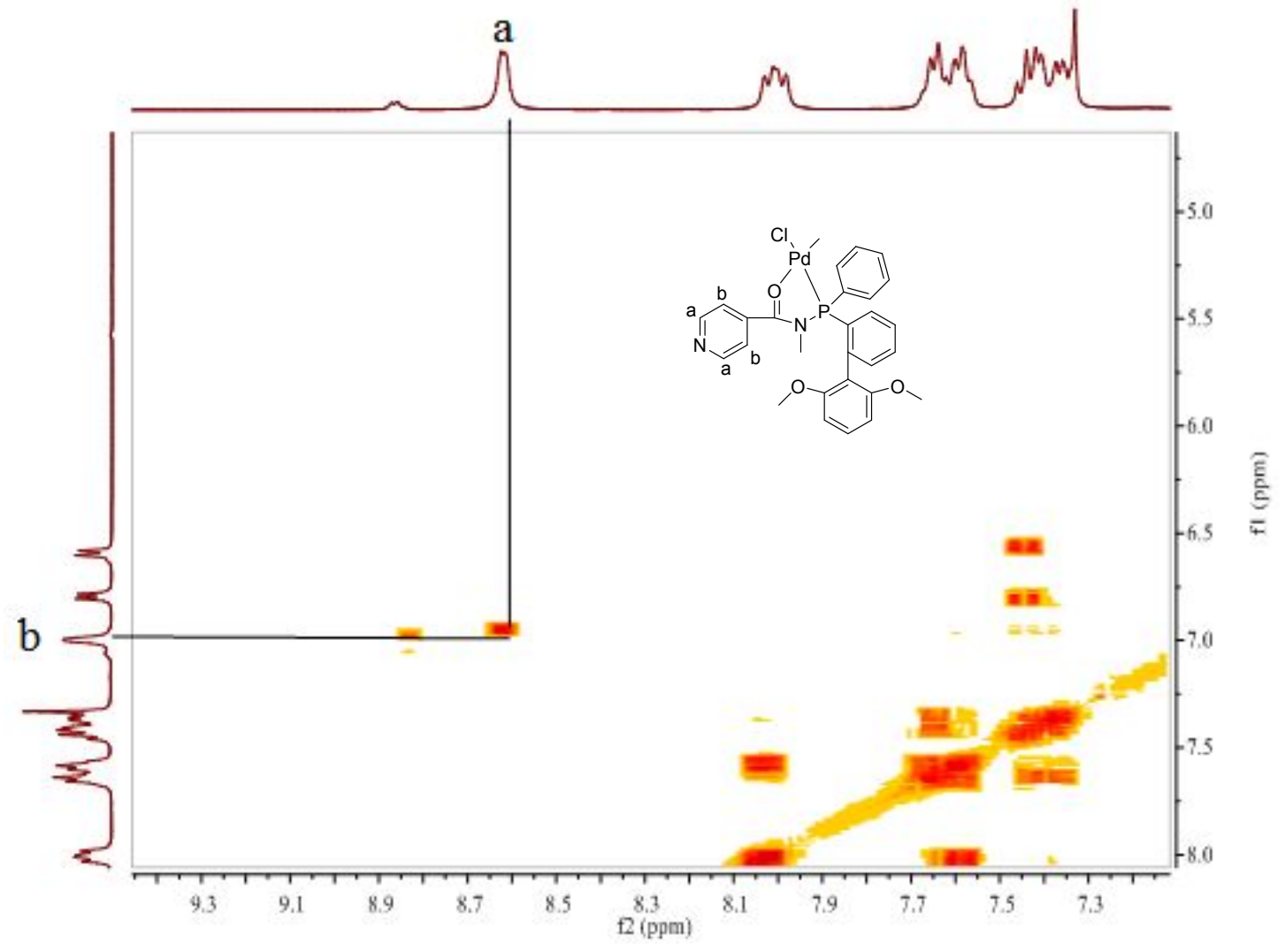

Figure S60. COSY spectrum (400 MHz, CDCl3) of Pd8. 


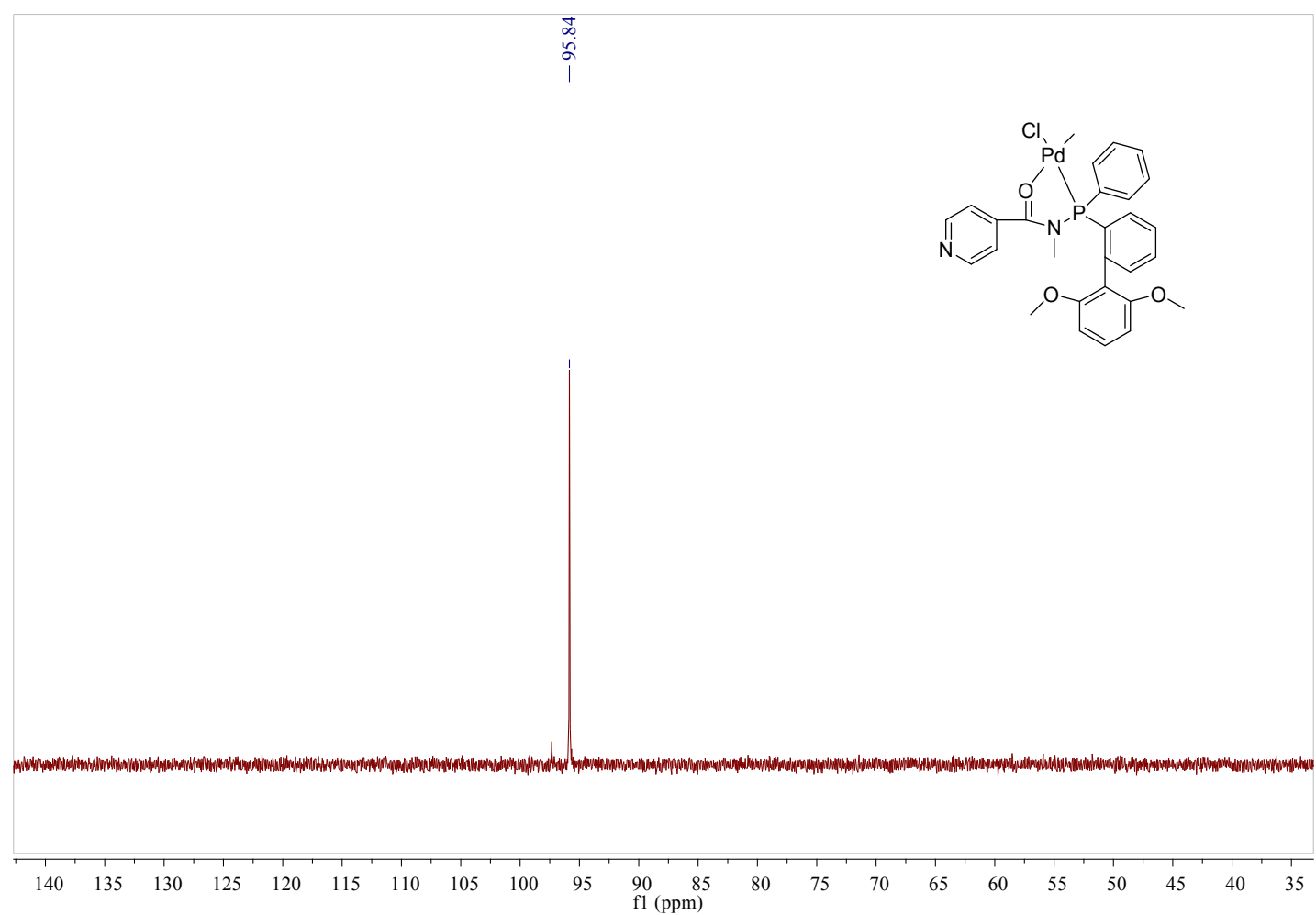

Figure S61. ${ }^{31} \mathrm{P}$ NMR spectrum $\left(\mathrm{CDCl}_{3}\right)$ of $\mathbf{P d 8}$.

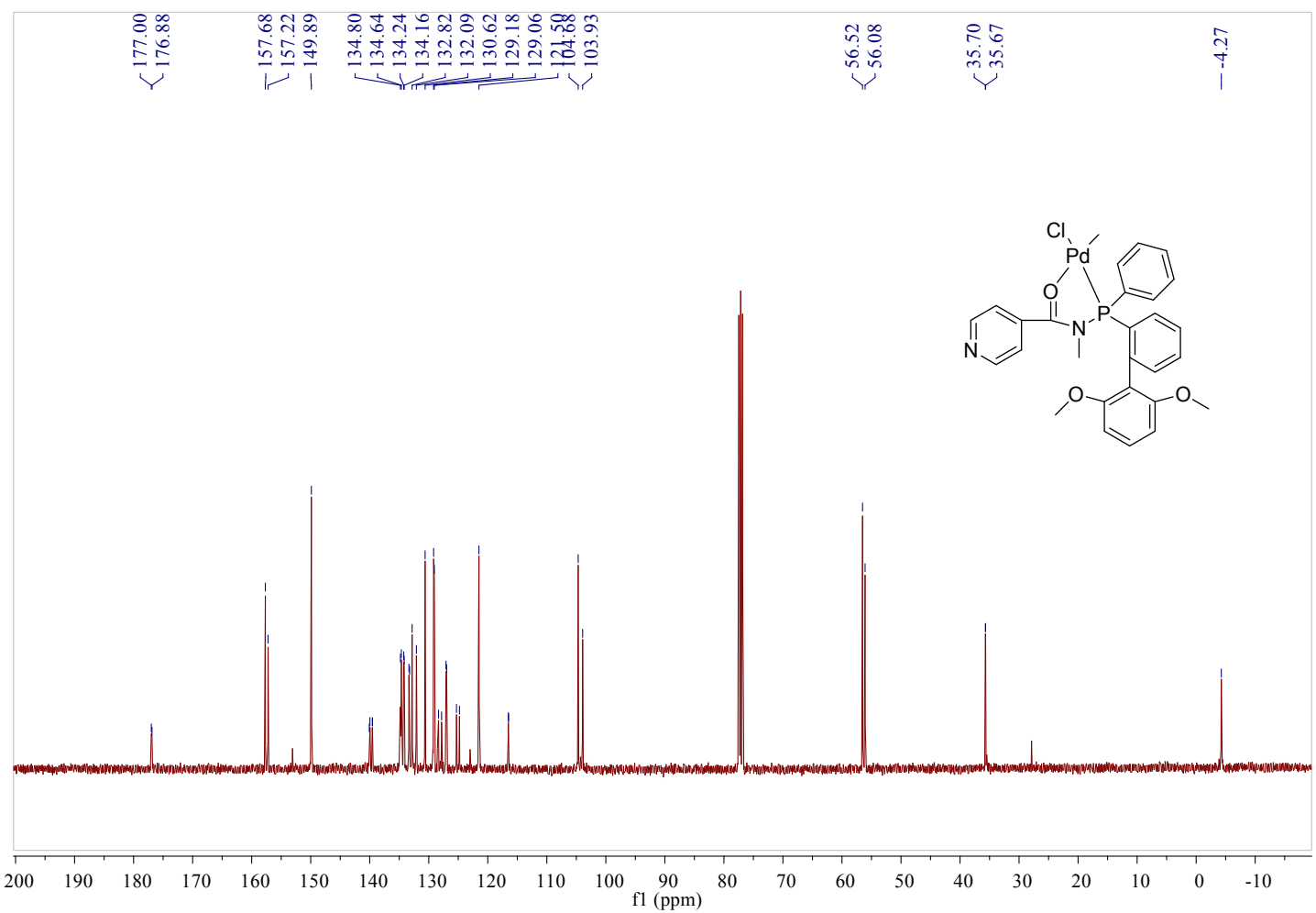

Figure S62. ${ }^{13} \mathrm{C}$ NMR spectrum in $\mathrm{CDCl}_{3}$ of $\mathbf{P d 8}$. 


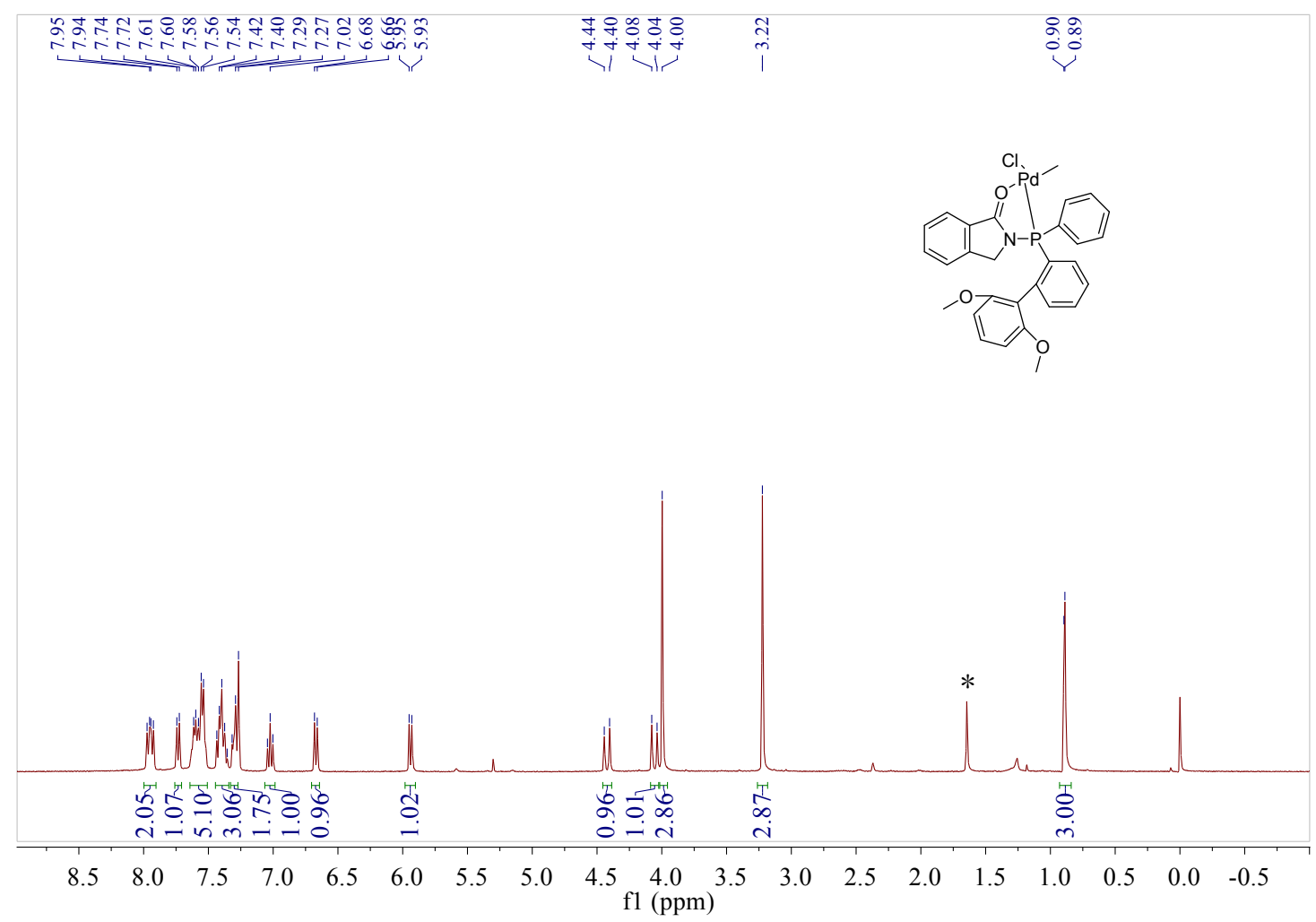

Figure S63. ${ }^{1} \mathrm{H}$ NMR spectrum (400 MHz, $\mathrm{CDCl}_{3}$ ) of $\mathbf{P d 9}$. ${ }^{*} \mathrm{H}_{2} \mathrm{O}$.

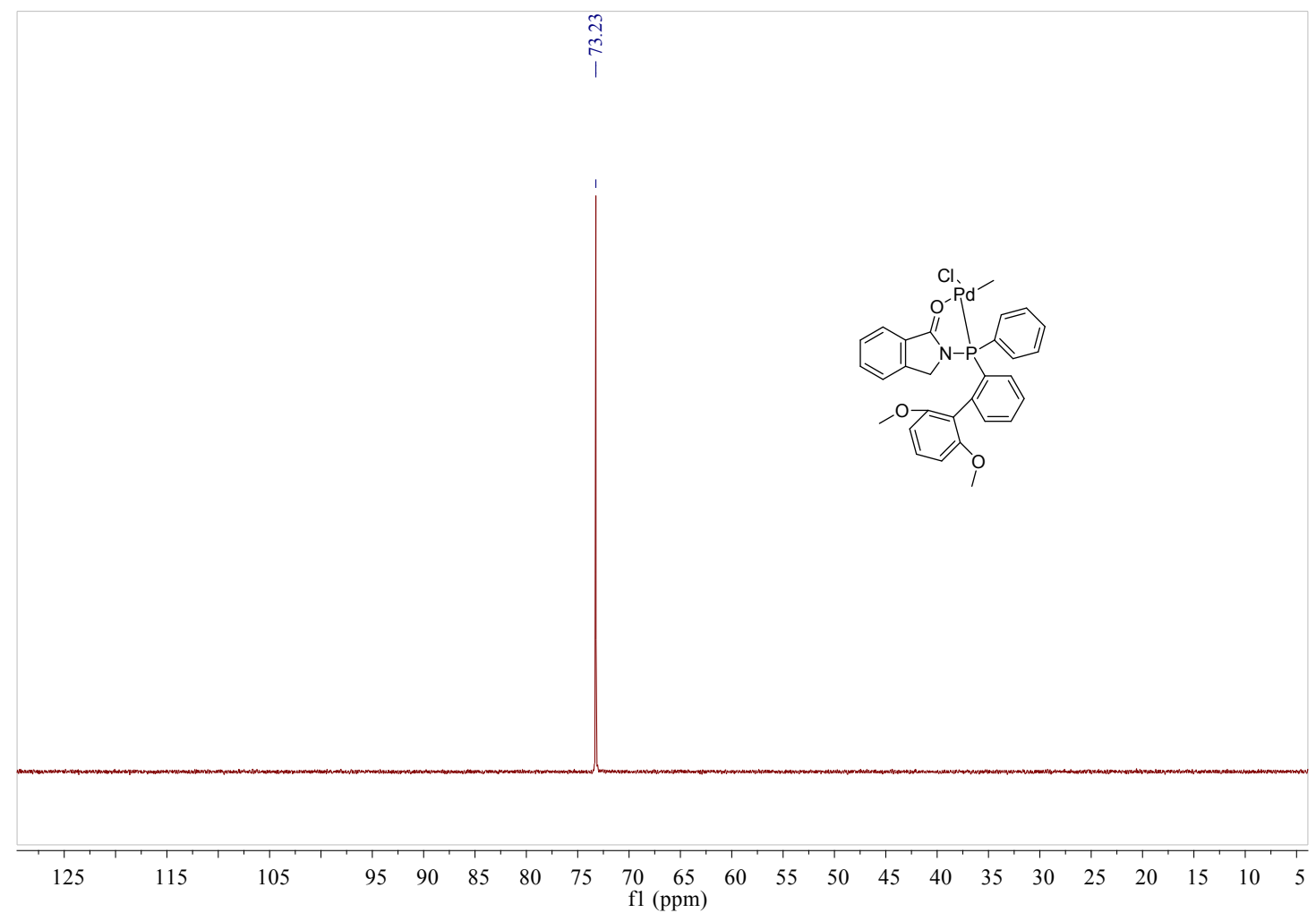

Figure S64. ${ }^{31} \mathrm{P}$ NMR spectrum $\left(\mathrm{CDCl}_{3}\right)$ of $\mathbf{P d 9}$. 


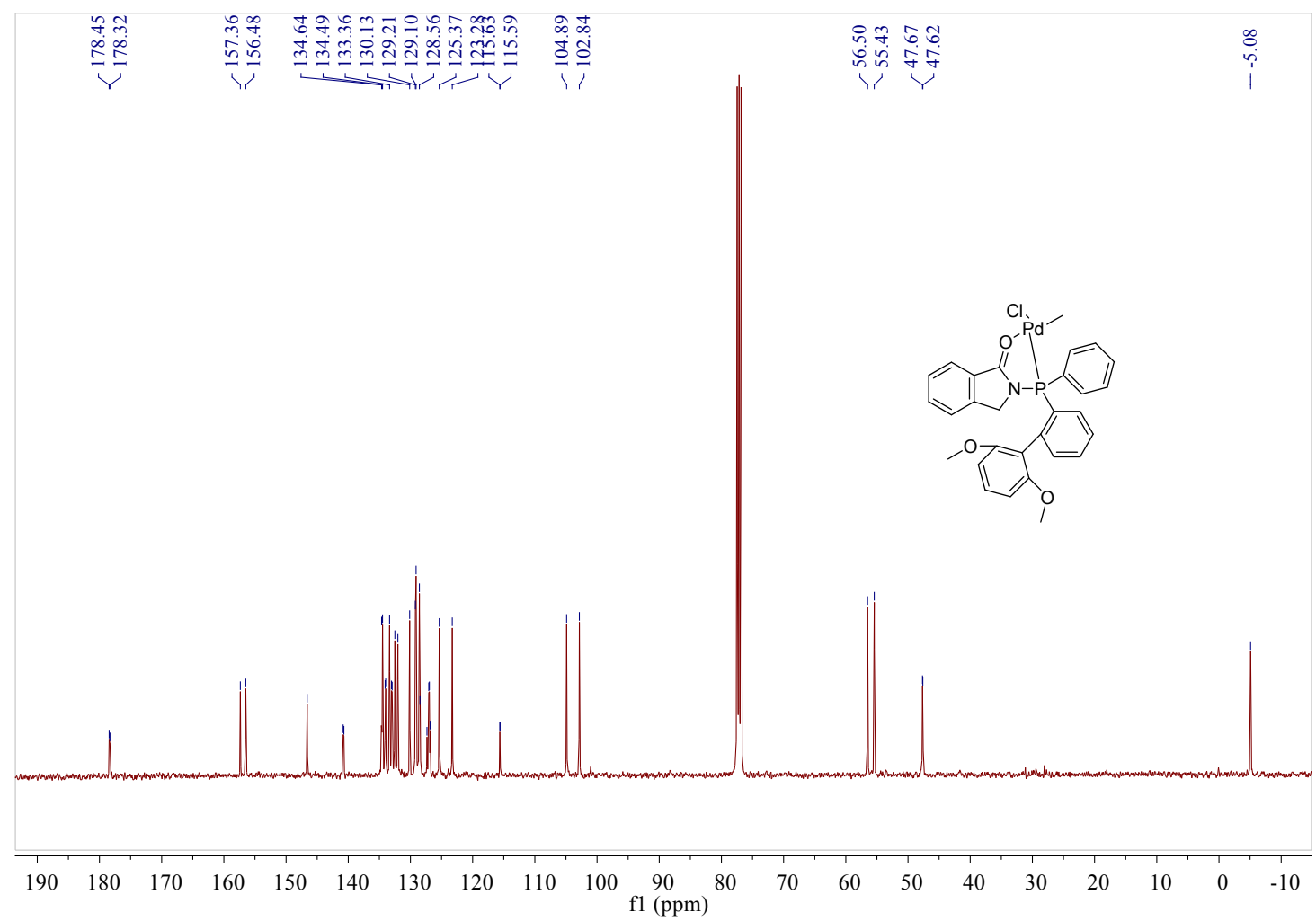

Figure $\mathbf{S 6 5} .{ }^{13} \mathrm{C}$ NMR spectrum in $\mathrm{CDCl}_{3}$ of $\mathbf{P d 9}$.

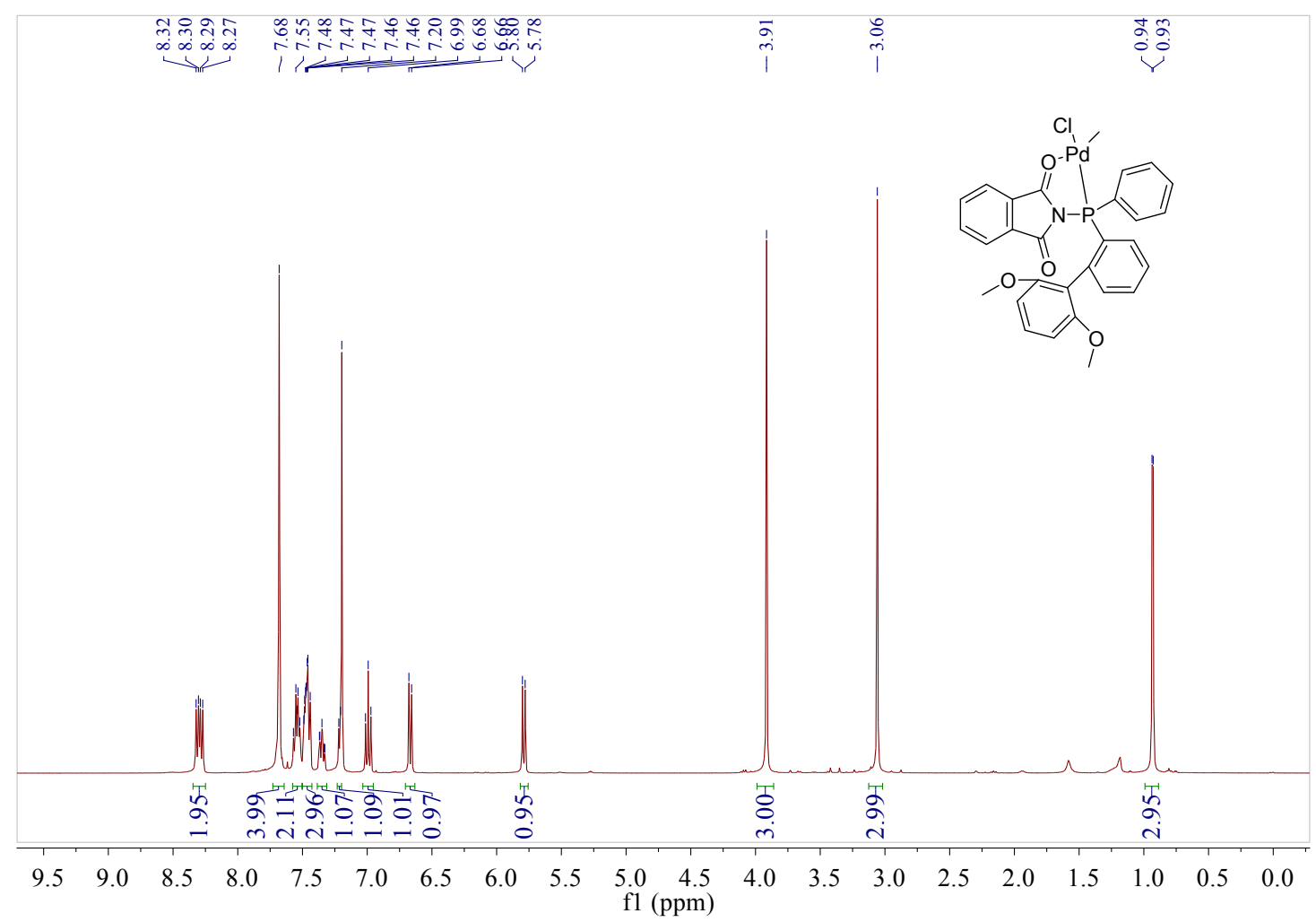

Figure S66. ${ }^{1} \mathrm{H}$ NMR spectrum (400 MHz, $\mathrm{CDCl}_{3}$ ) of Pd10. 


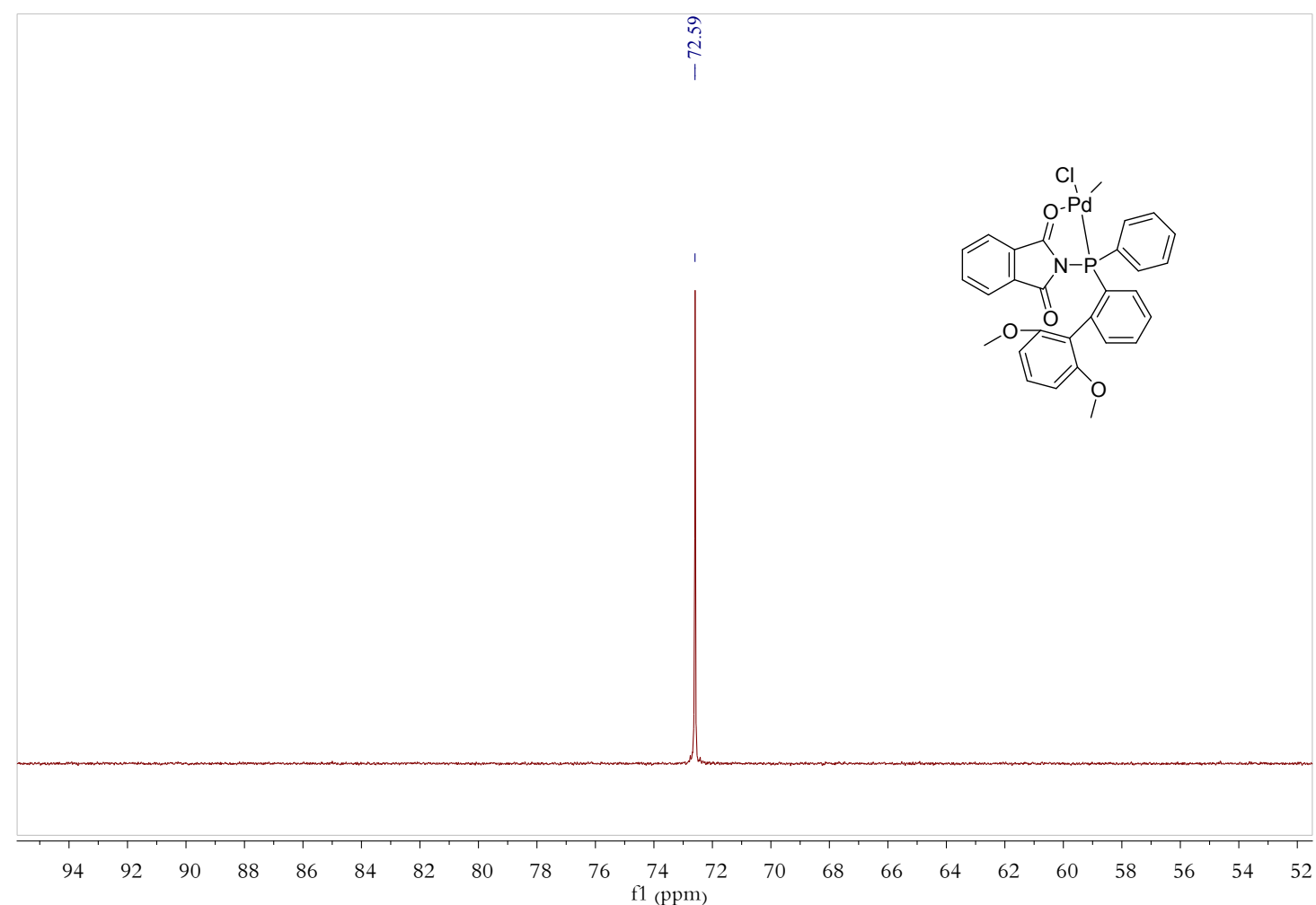

Figure S67. ${ }^{31} \mathrm{P}$ NMR spectrum $\left(\mathrm{CDCl}_{3}\right)$ of Pd10.

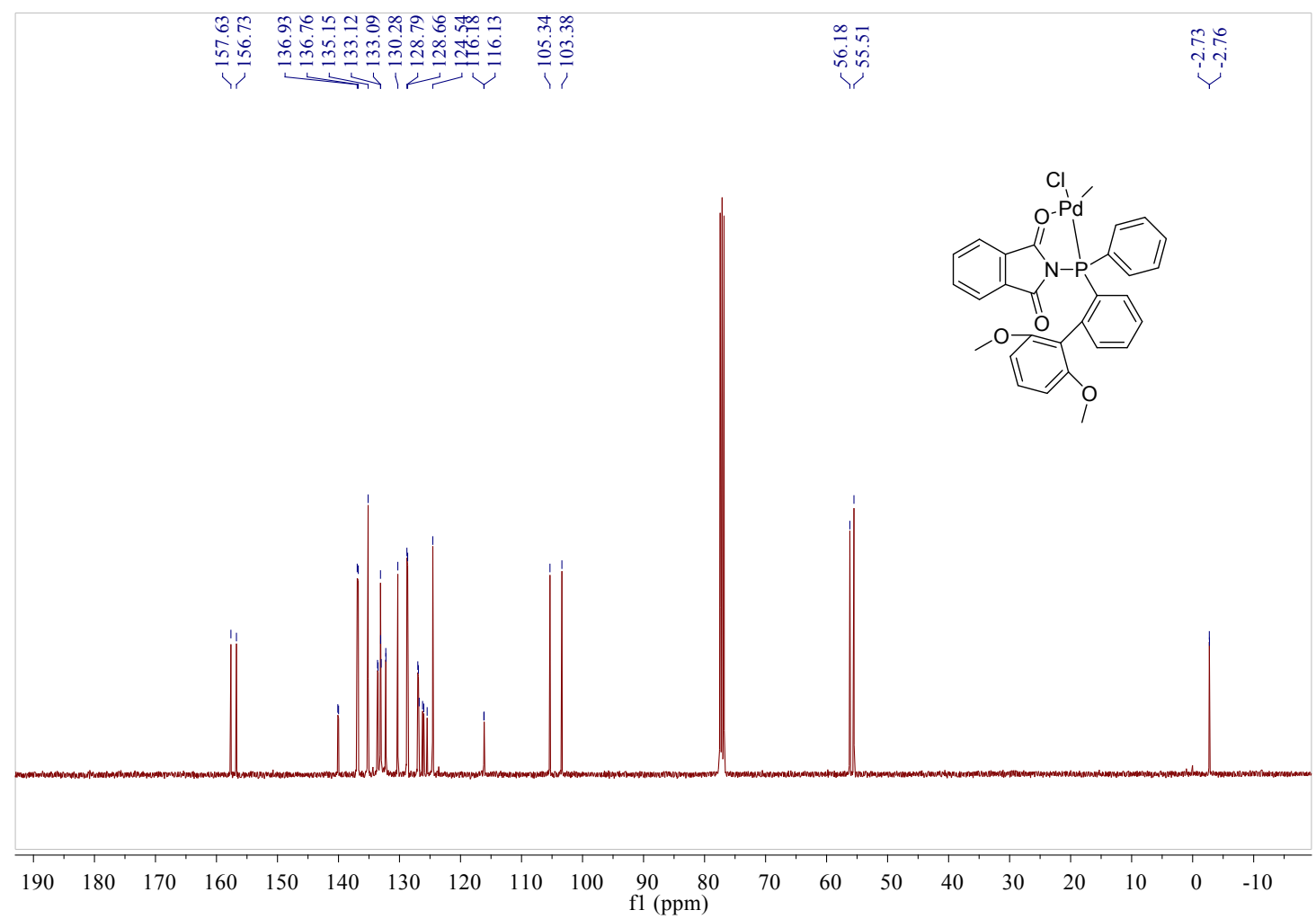

Figure S68. ${ }^{13} \mathrm{C}$ NMR spectrum in $\mathrm{CDCl}_{3}$ of $\mathbf{P d 1 0}$. 


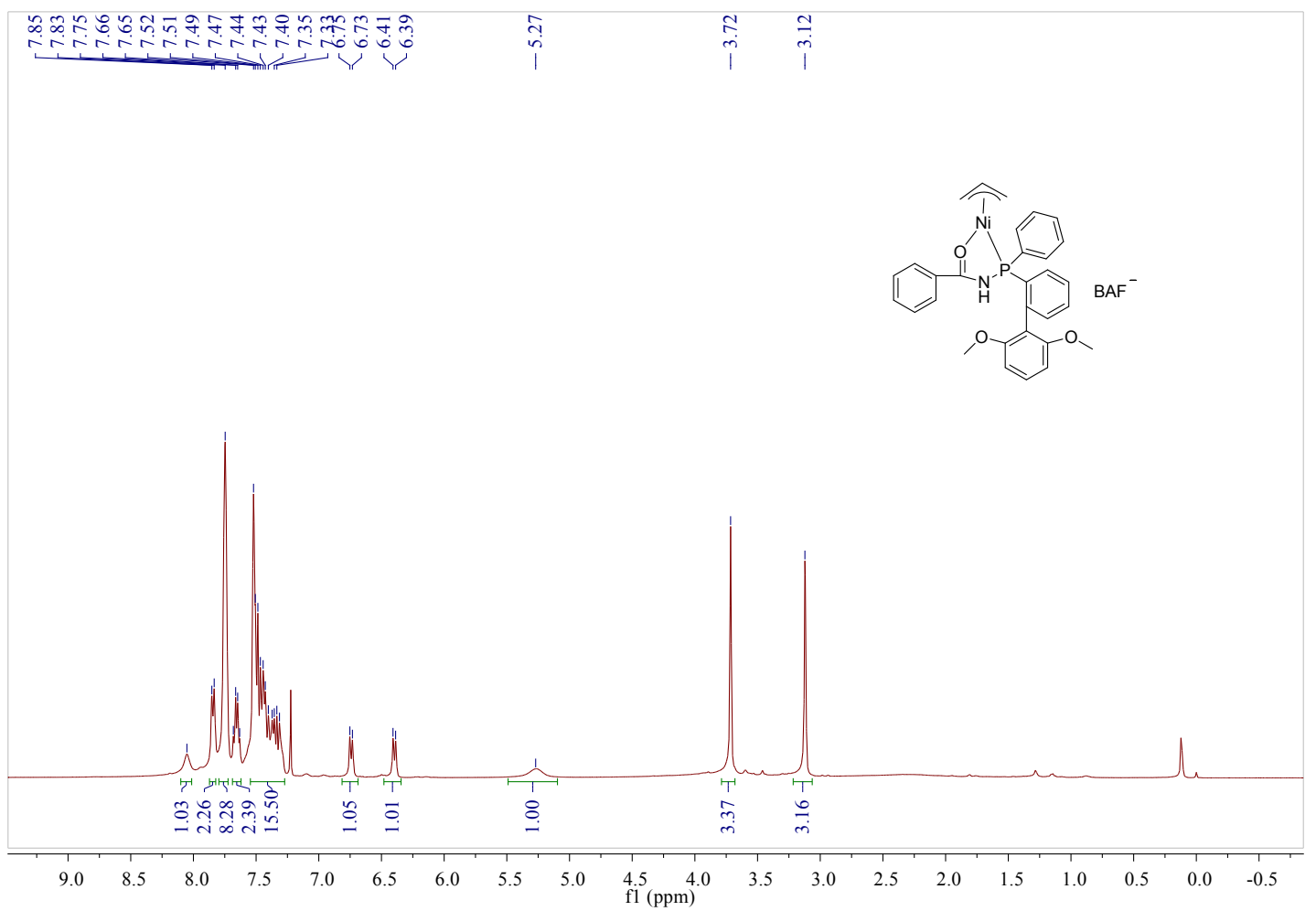

Figure S69. ${ }^{1} \mathrm{H}$ NMR spectrum $\left(400 \mathrm{MHz}, \mathrm{CDCl}_{3}\right)$ of Ni1.

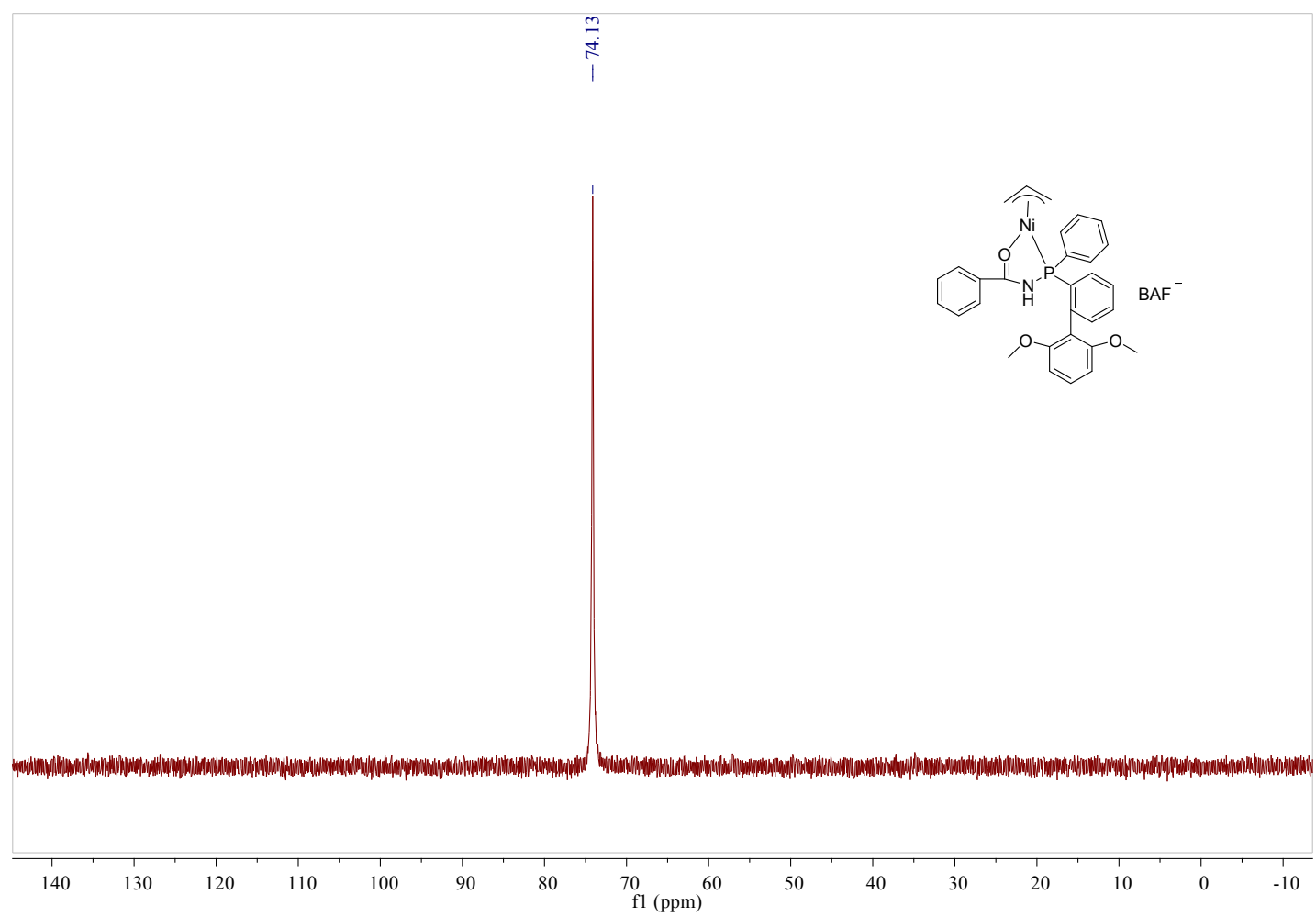

Figure S70. ${ }^{1} \mathrm{H}$ NMR spectrum $\left(400 \mathrm{MHz}, \mathrm{CDCl}_{3}\right)$ of Ni1. 


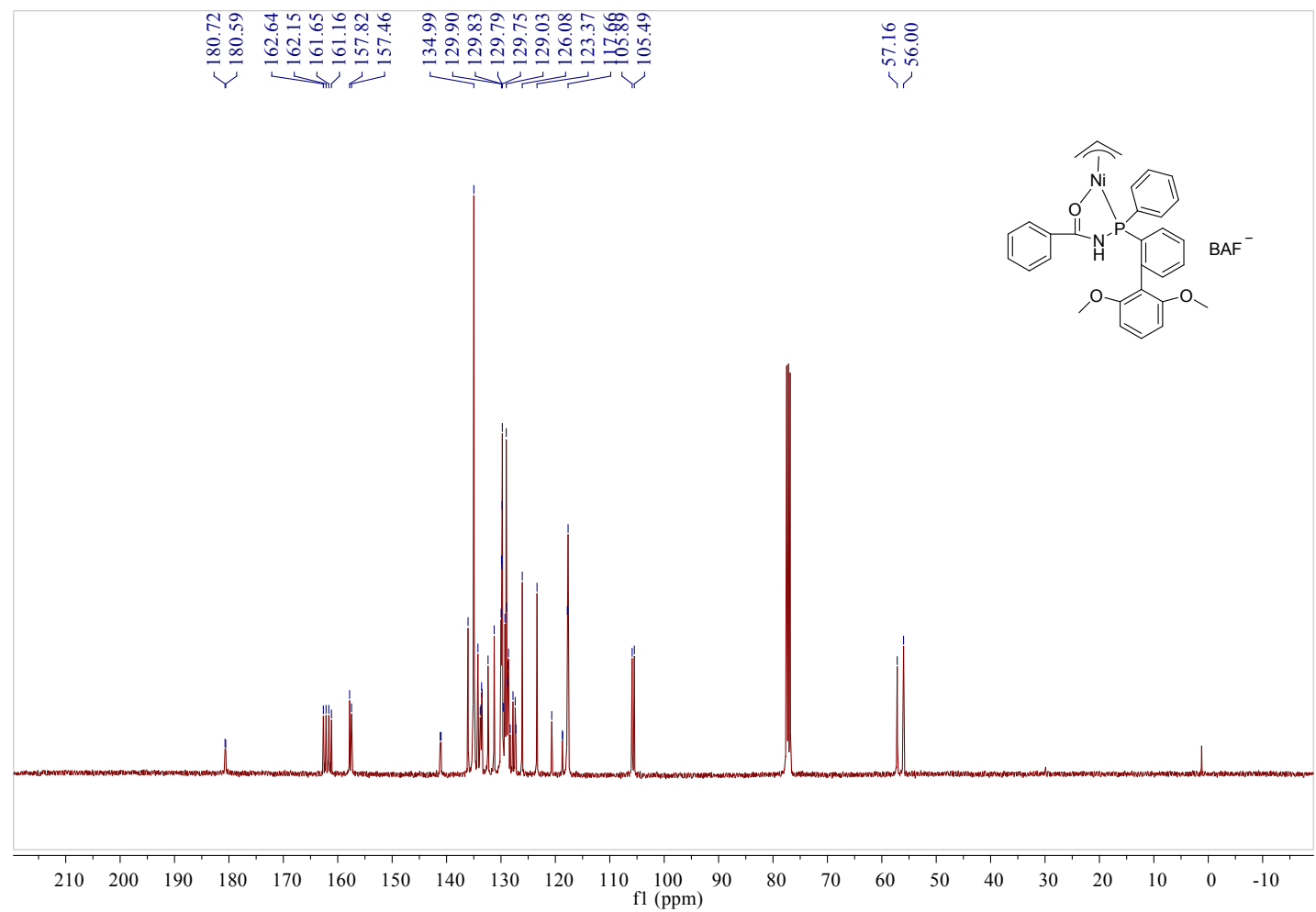

Figure $\mathbf{S 7 1} .{ }^{13} \mathrm{C}$ NMR spectrum in $\mathrm{CDCl}_{3}$ of Ni1.

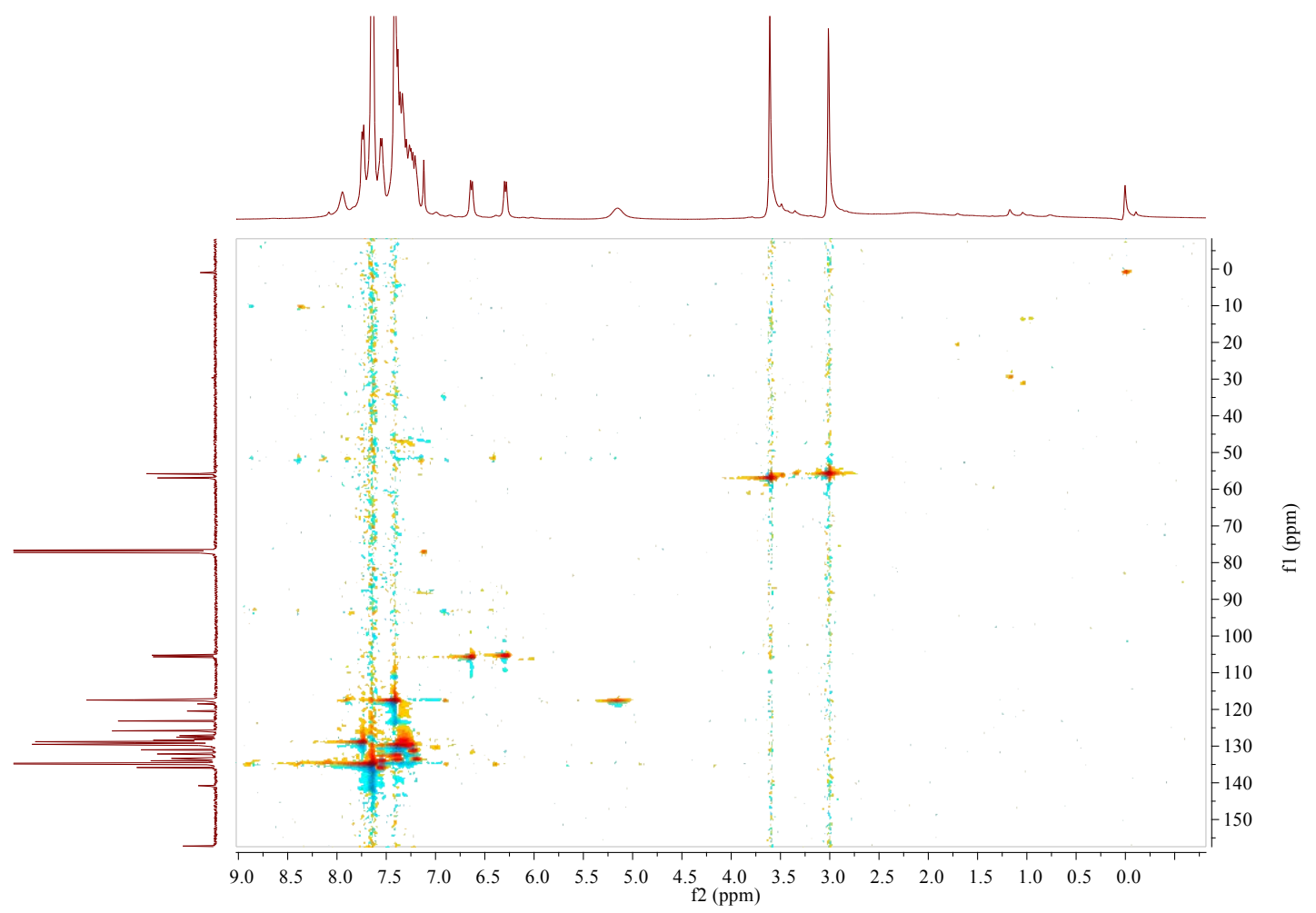

Figure S72. ${ }^{1} \mathrm{H}-{ }^{13} \mathrm{C}$ HSQC NMR spectrum of Ni1 in $\mathrm{CDCl}_{3}$. 


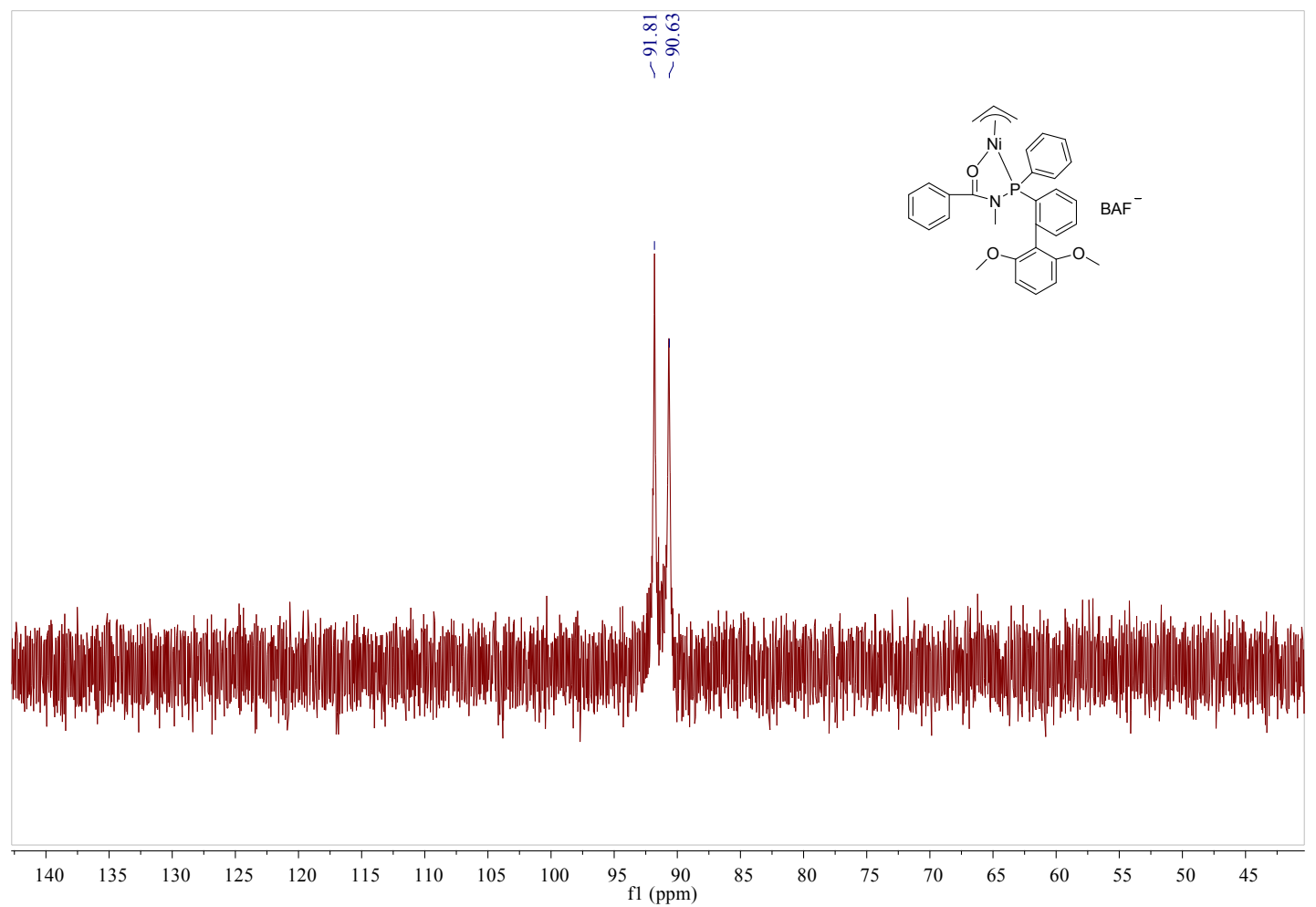

Figure S73. ${ }^{31} \mathrm{P}$ NMR spectrum $\left(\mathrm{CDCl}_{3}\right)$ of $\mathbf{N i 2}$.

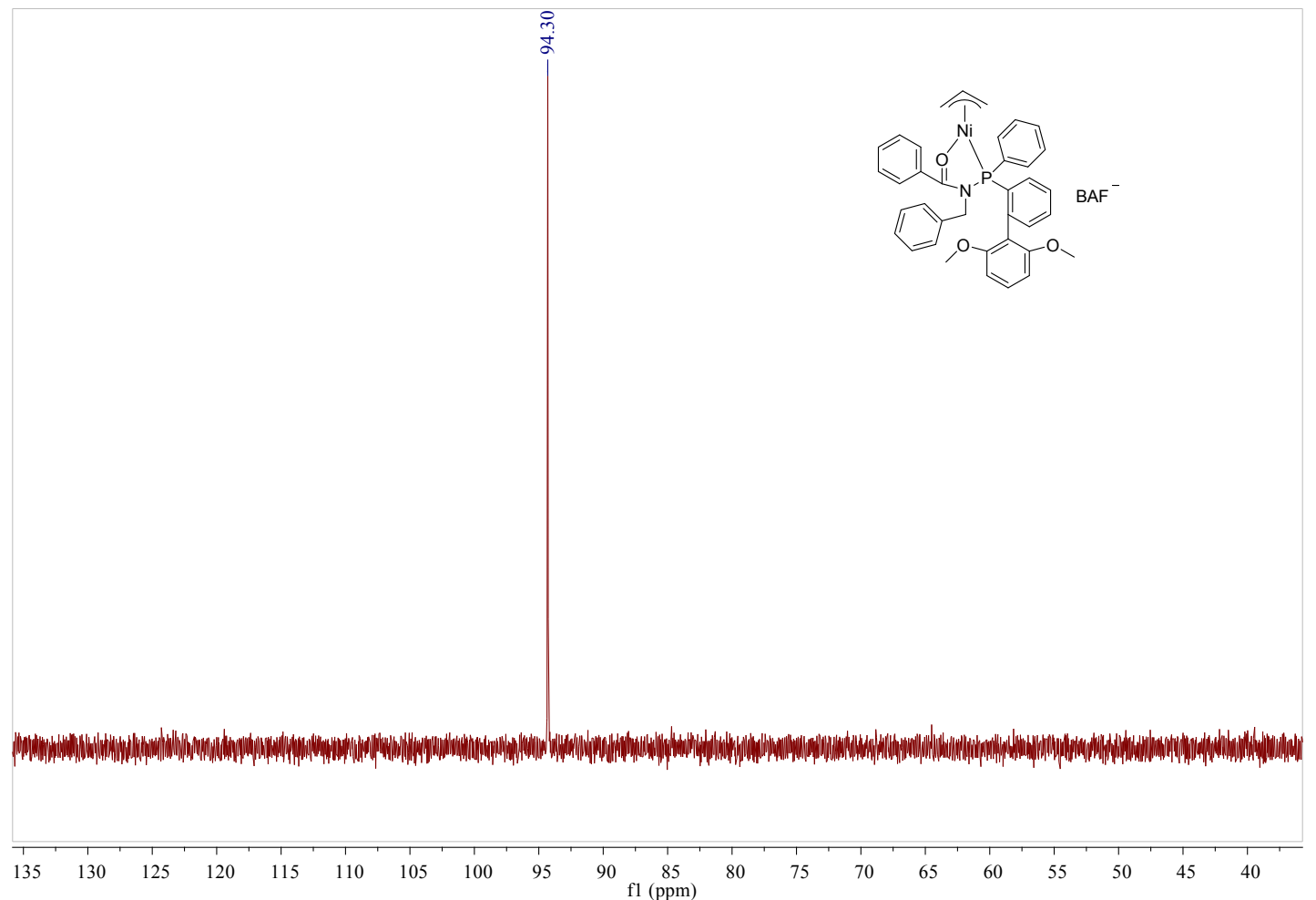

Figure S74. ${ }^{31} \mathrm{P}$ NMR spectrum $\left(\mathrm{CDCl}_{3}\right)$ of Ni3. 


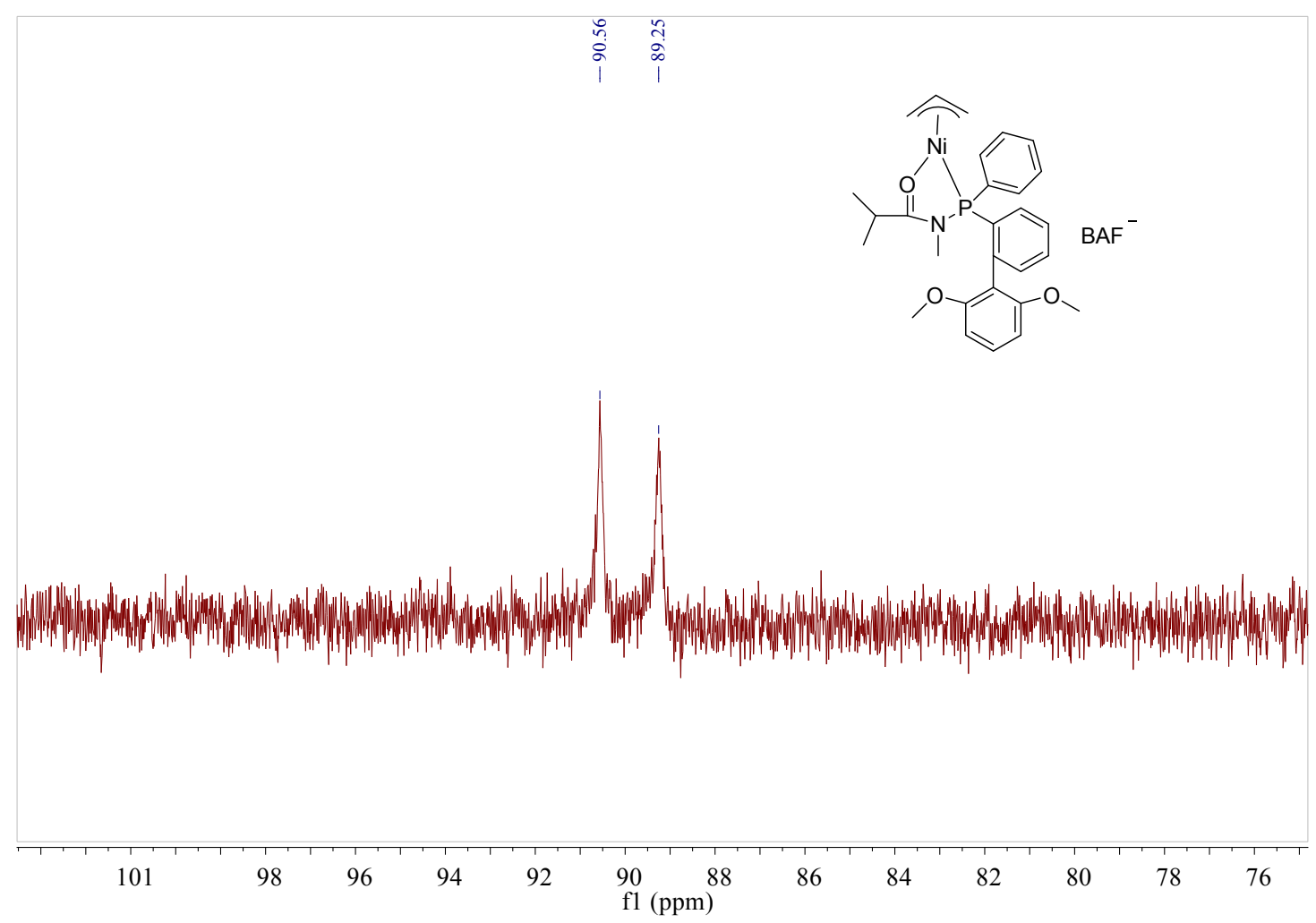

Figure S75. ${ }^{31} \mathrm{P}$ NMR spectrum $\left(\mathrm{CDCl}_{3}\right)$ of $\mathbf{N i 4}$.

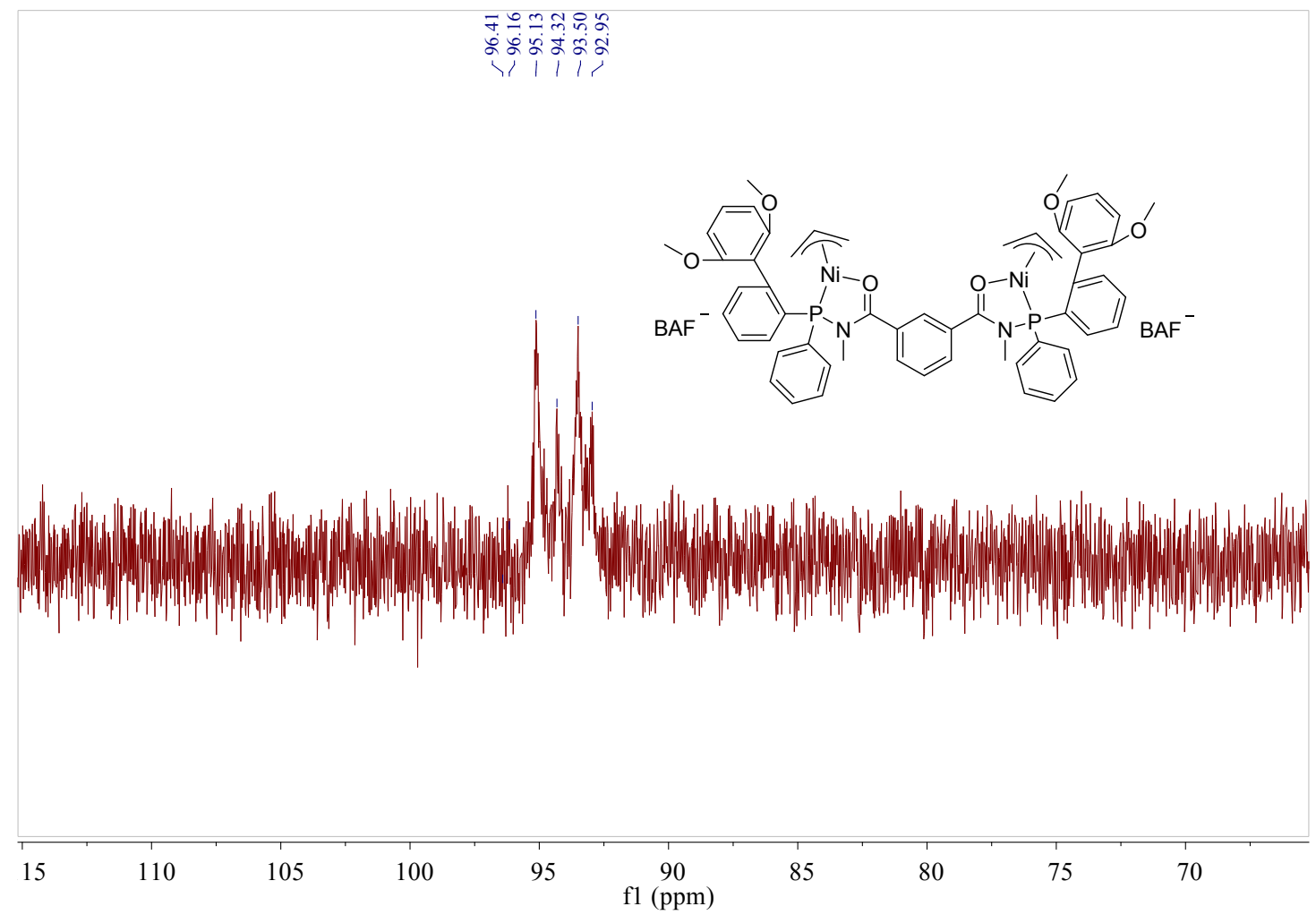

Figure S76. ${ }^{31} \mathrm{P}$ NMR spectrum $\left(\mathrm{CDCl}_{3}\right)$ of Ni5. 


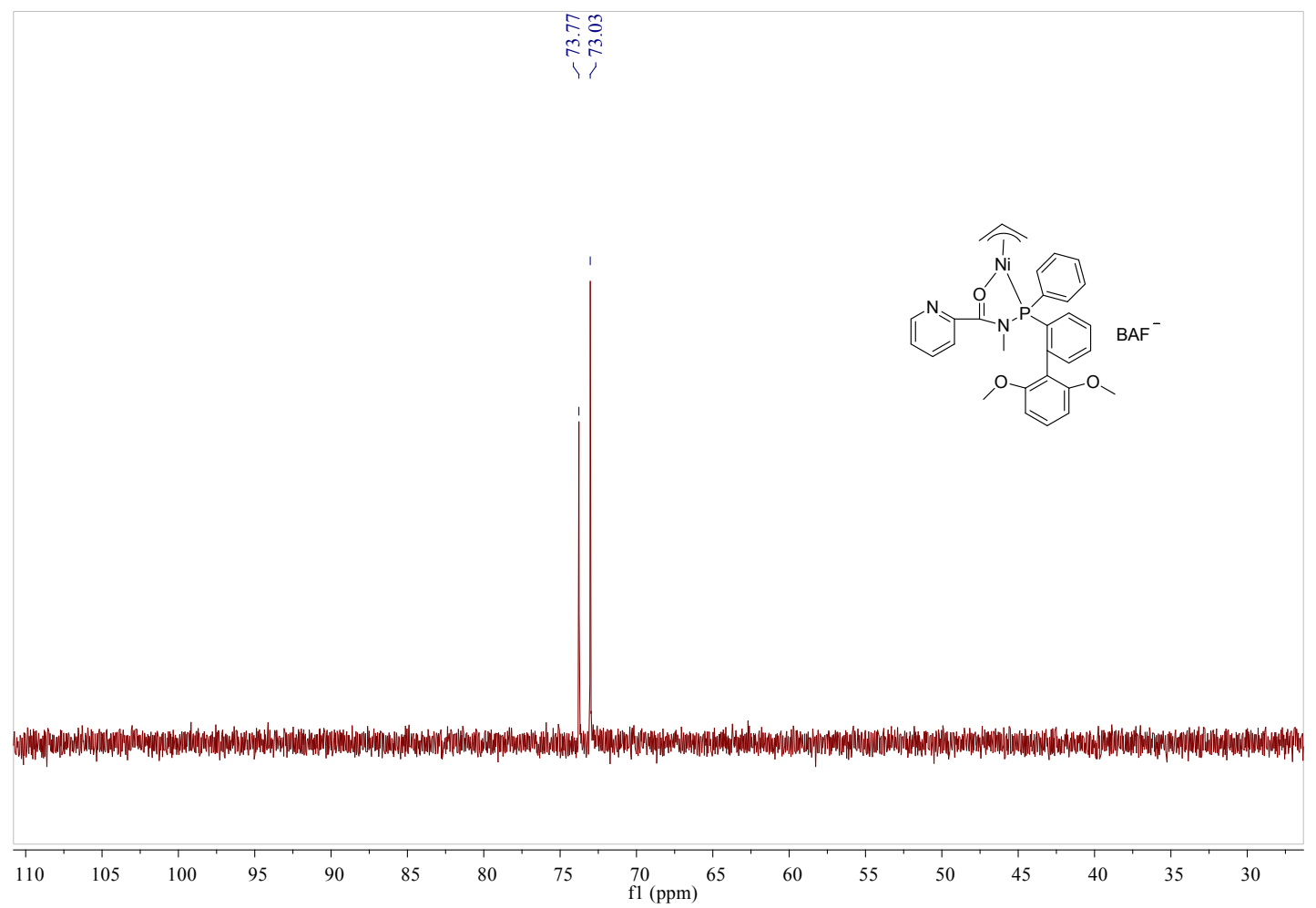

Figure S77. ${ }^{31} \mathrm{P}$ NMR spectrum $\left(\mathrm{CDCl}_{3}\right)$ of Ni6.

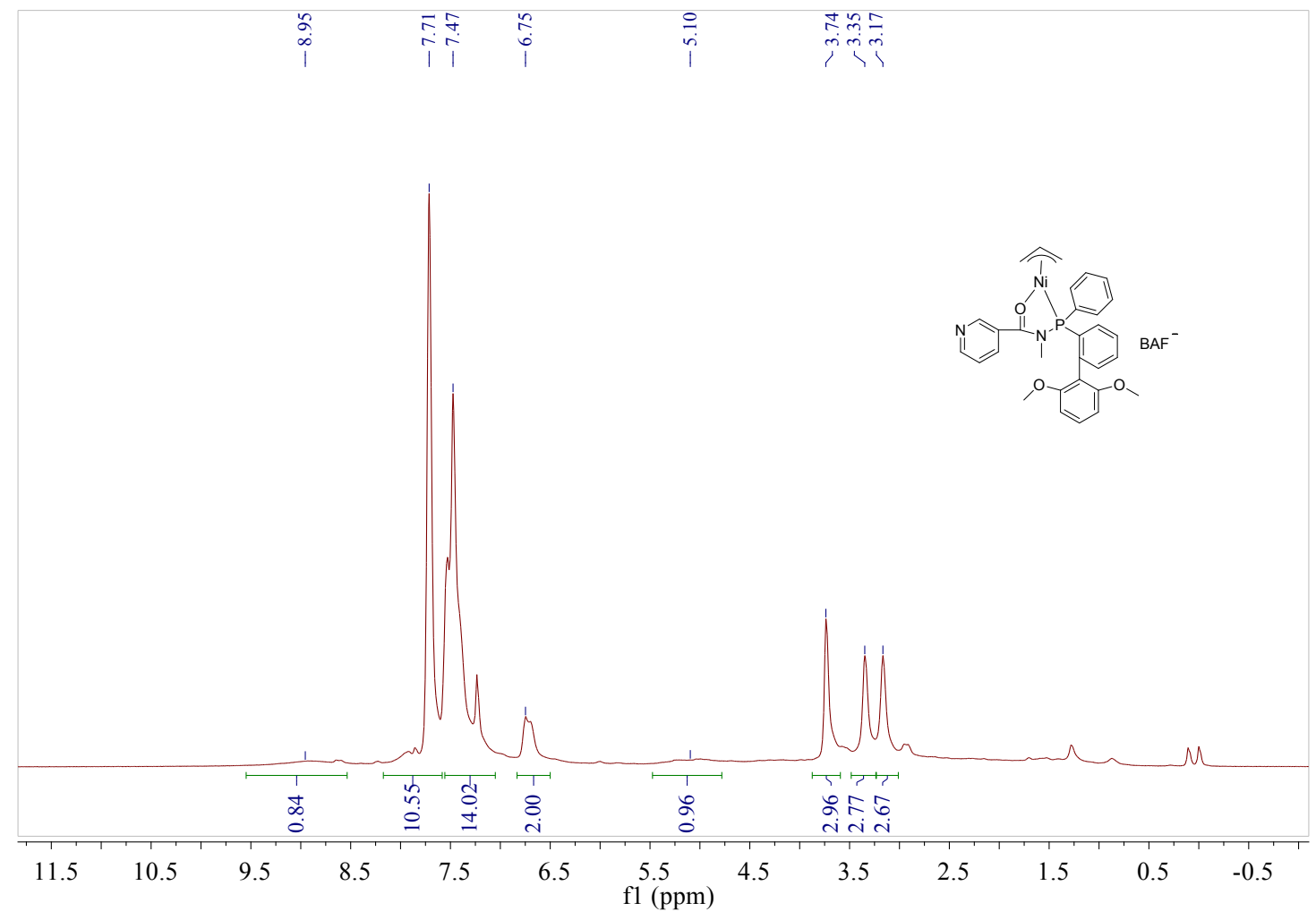

Figure S78. ${ }^{1} \mathrm{H}$ NMR spectrum $\left(400 \mathrm{MHz}, \mathrm{CDCl}_{3}\right)$ of $\mathbf{N i 7}$. 


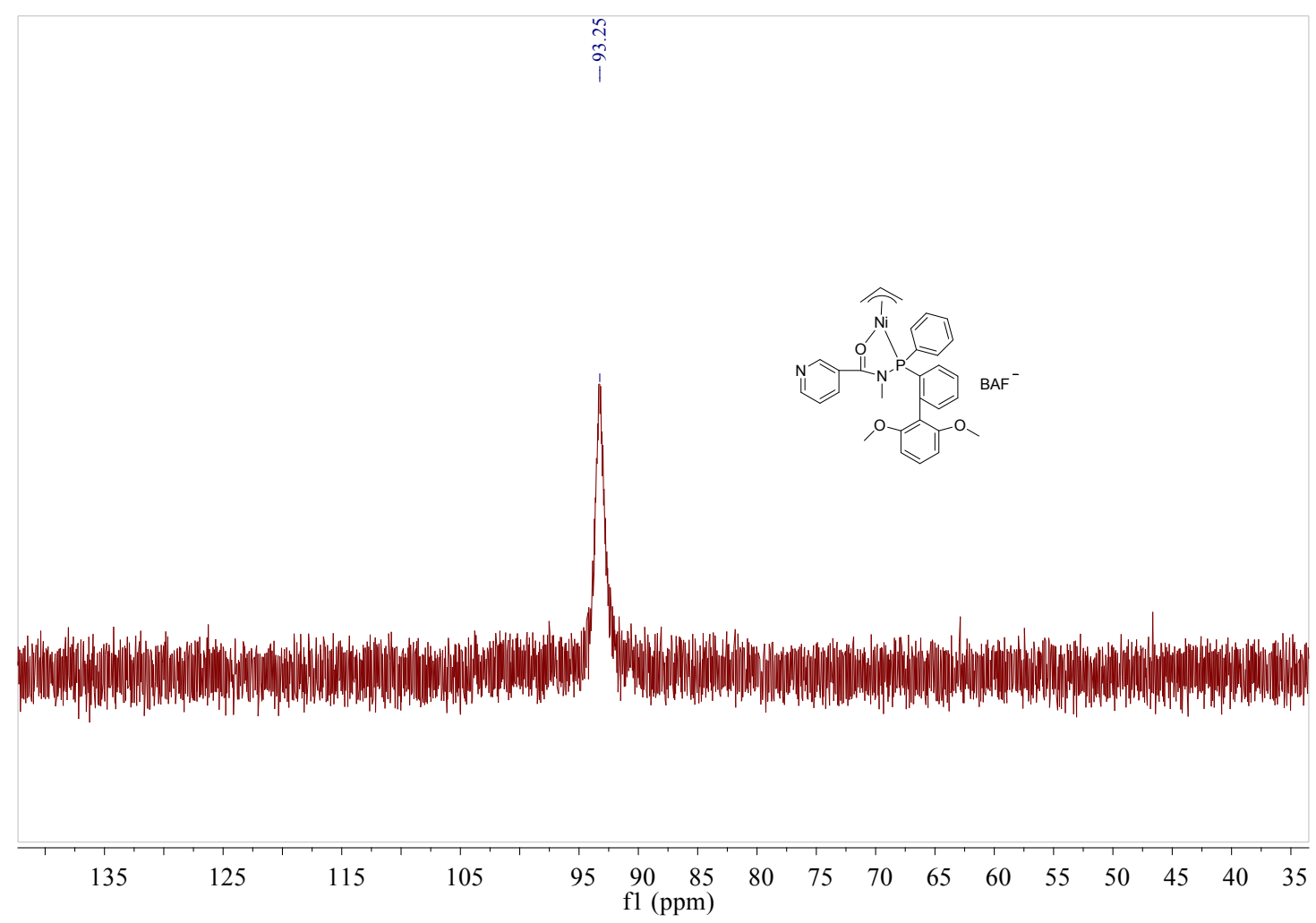

Figure S79. ${ }^{31} \mathrm{P}$ NMR spectrum $\left(\mathrm{CDCl}_{3}\right)$ of $\mathbf{N i 7}$.

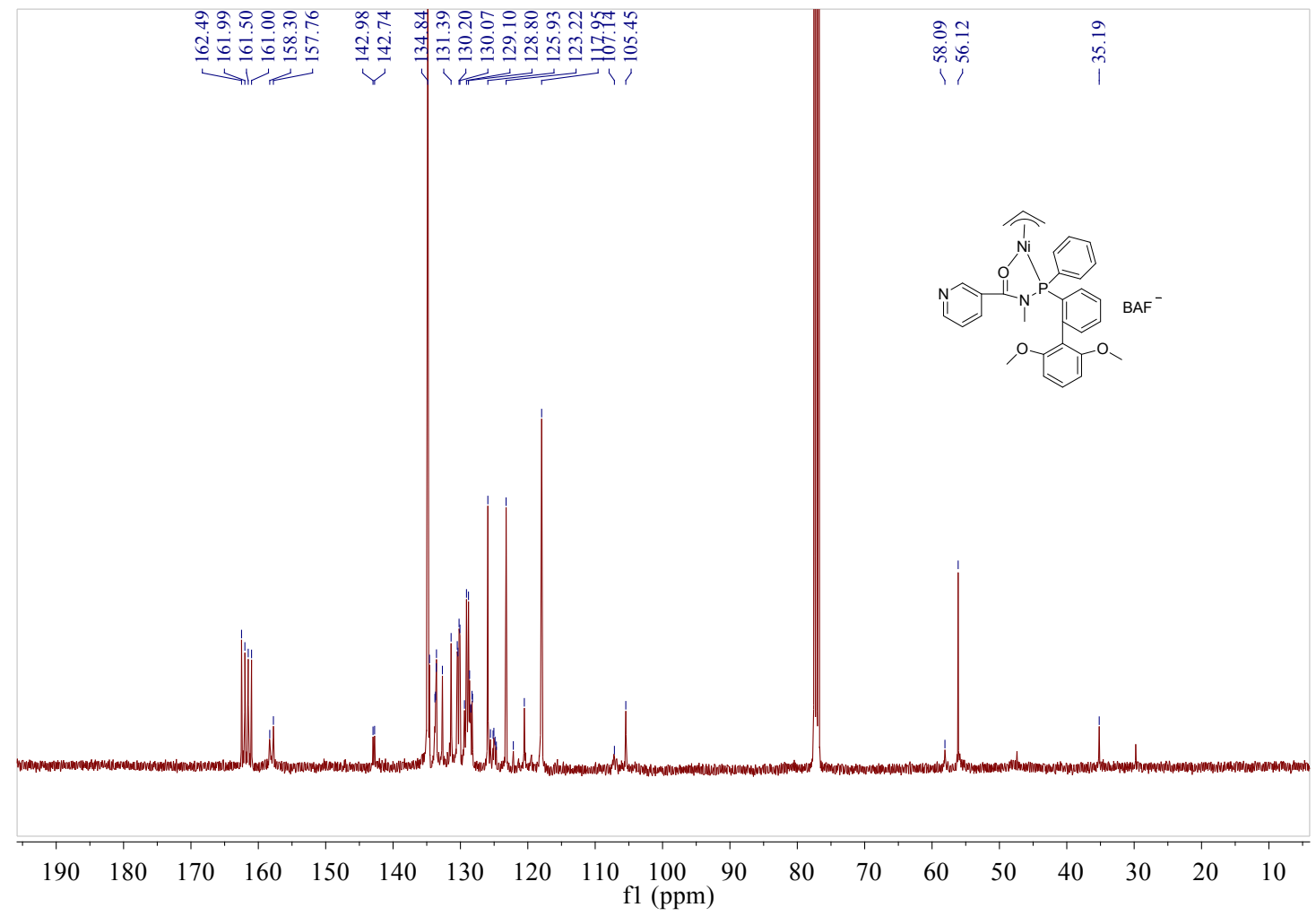

Figure S80. ${ }^{13} \mathrm{C}$ NMR spectrum in $\mathrm{CDCl}_{3}$ of $\mathrm{Ni7}$. 


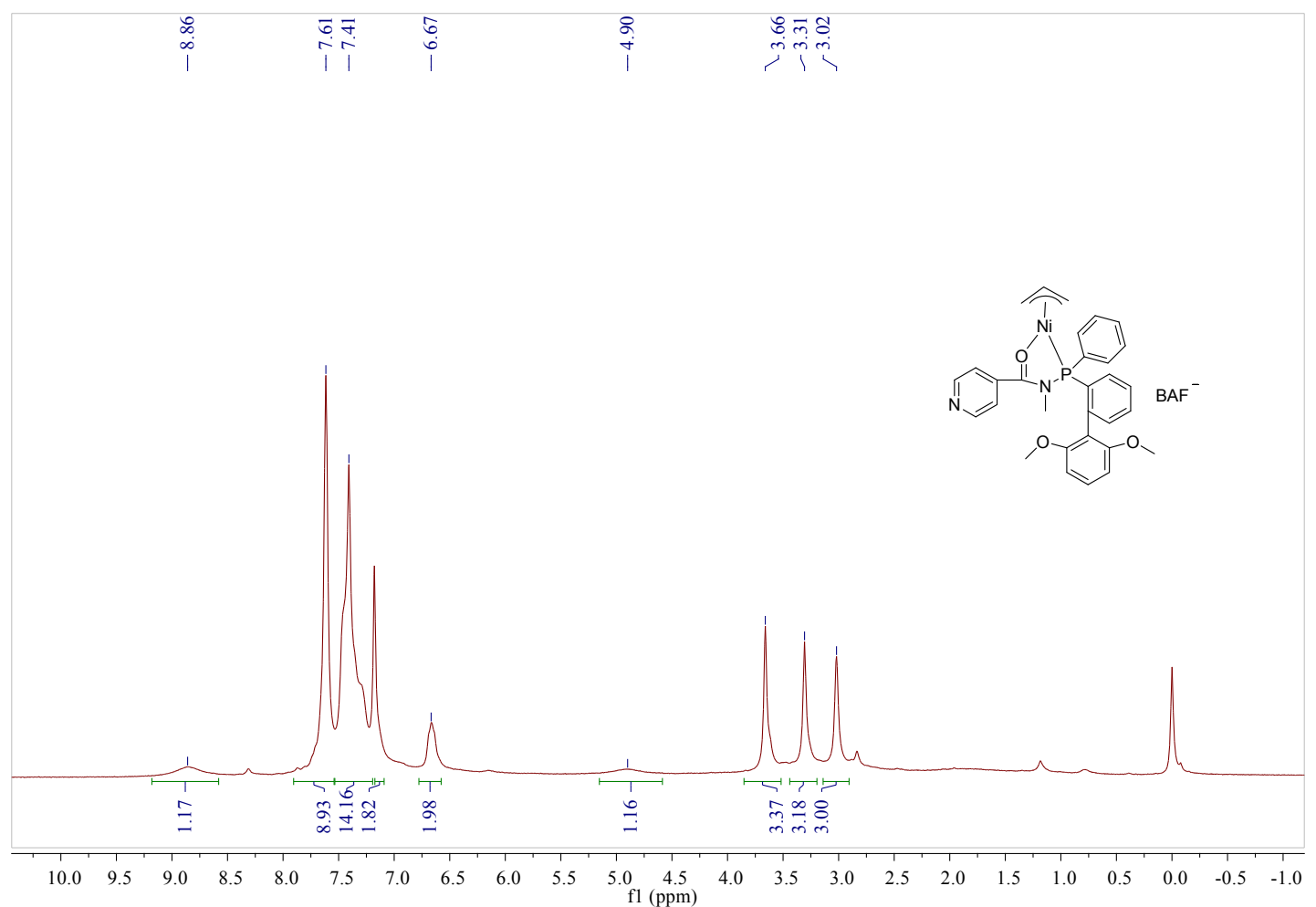

Figure S81. ${ }^{1} \mathrm{H}$ NMR spectrum $\left(400 \mathrm{MHz}, \mathrm{CDCl}_{3}\right)$ of $\mathbf{~ N i 8}$.

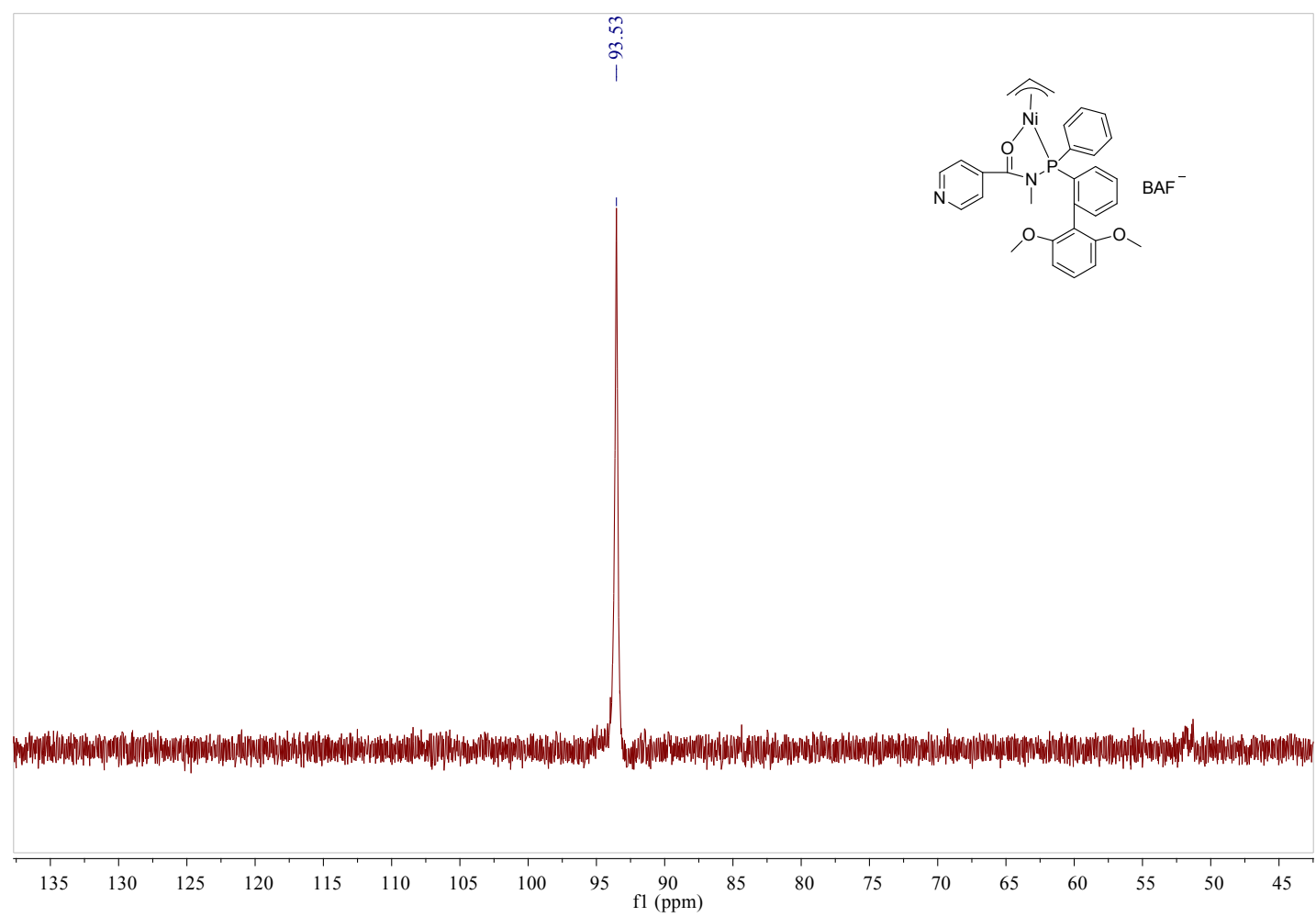

Figure S82. ${ }^{31} \mathrm{P}$ NMR spectrum $\left(\mathrm{CDCl}_{3}\right)$ of Ni8. 


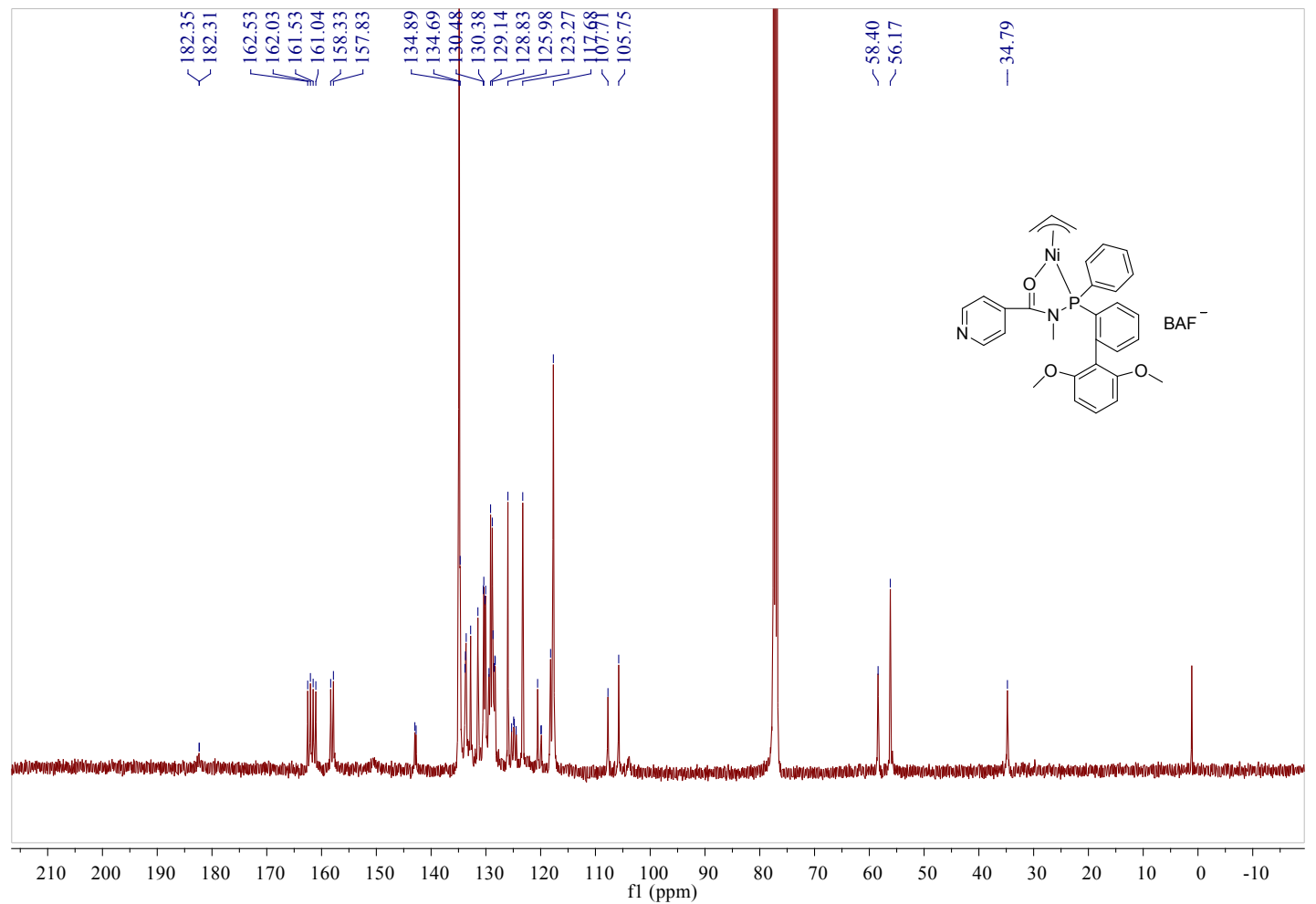

Figure 83. ${ }^{13} \mathrm{C}$ NMR spectrum in $\mathrm{CDCl}_{3}$ of $\mathbf{N i 8}$.

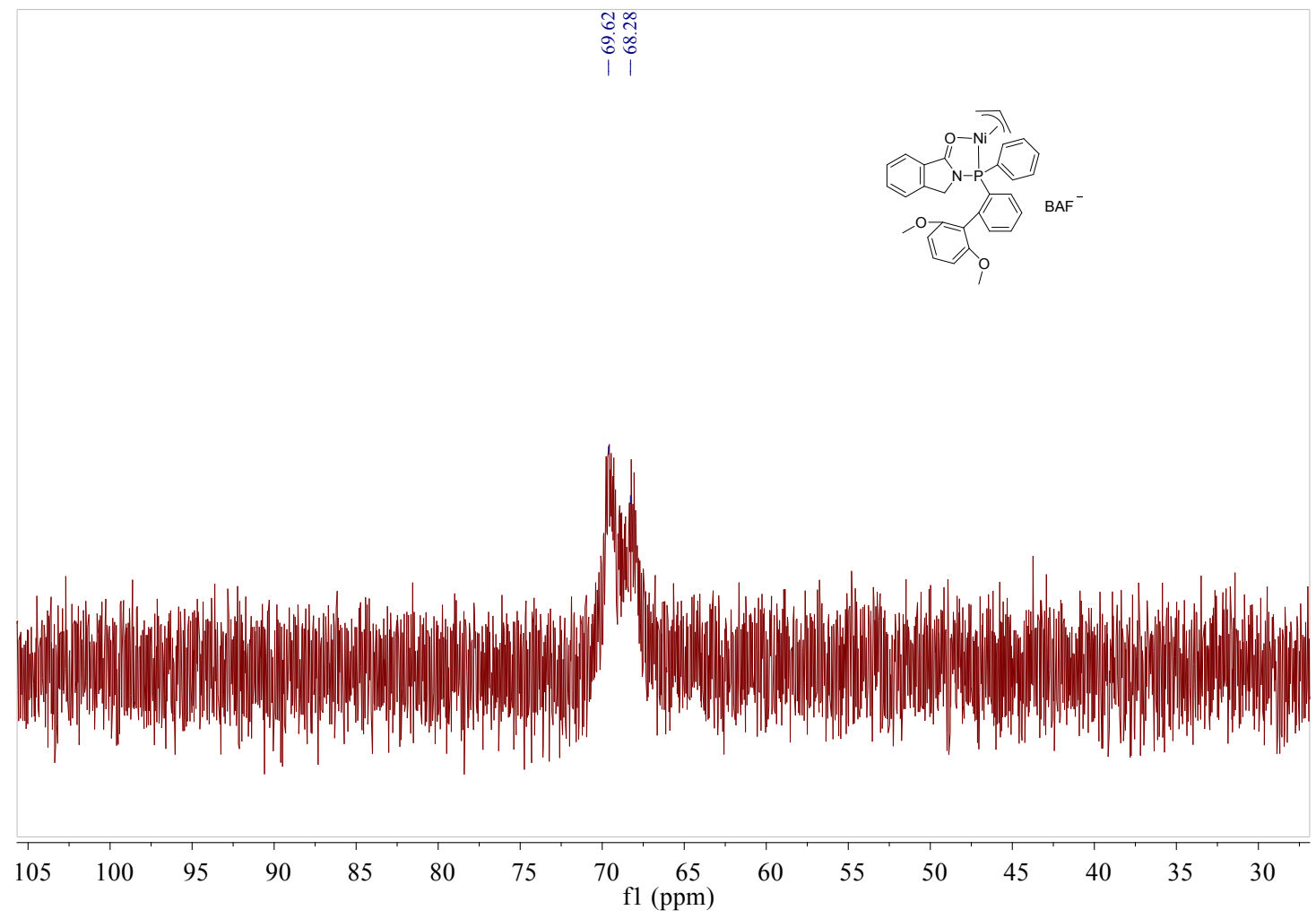

Figure S84. ${ }^{31} \mathrm{P}$ NMR spectrum $\left(\mathrm{CDCl}_{3}\right)$ of Ni9. 


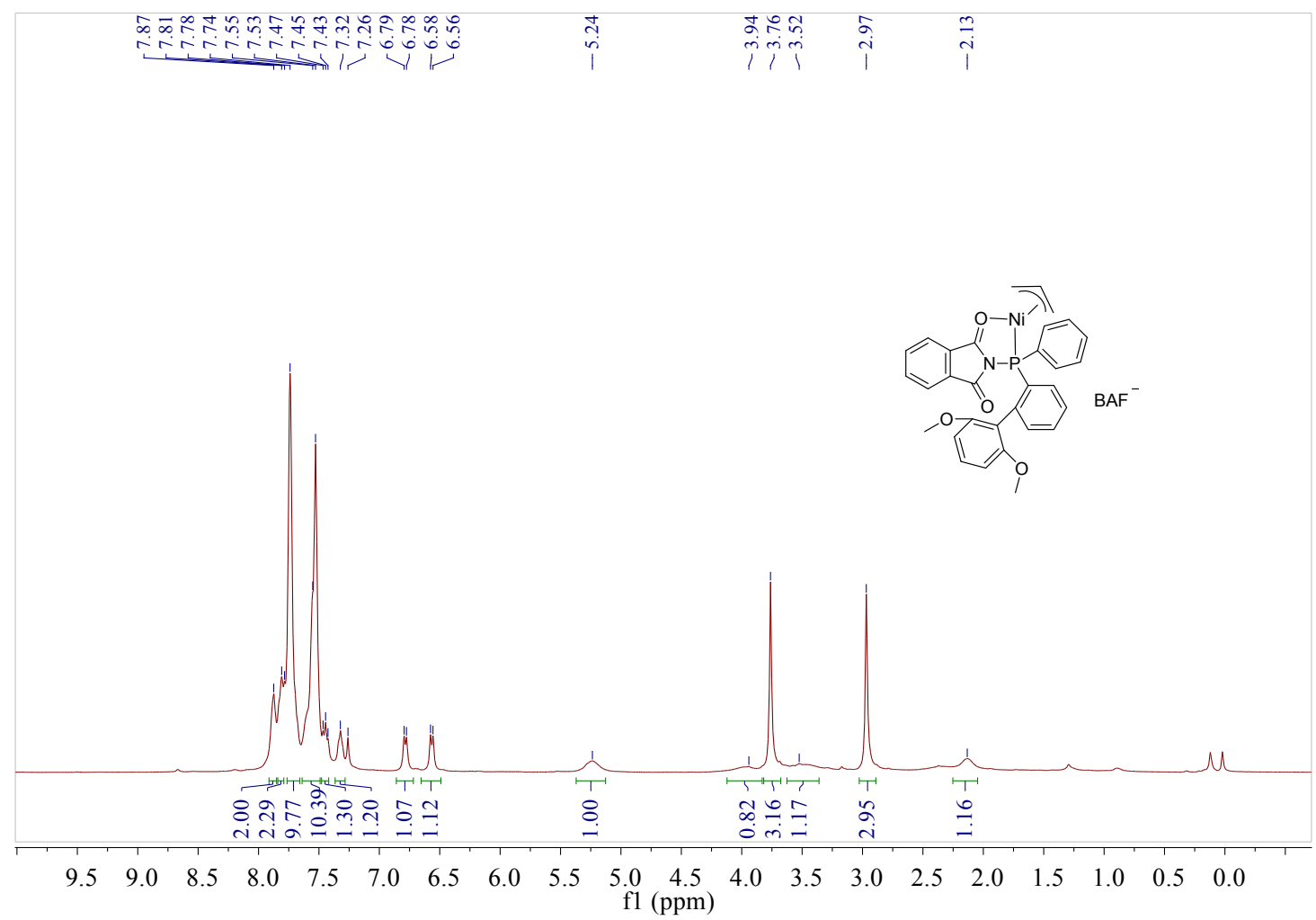

Figure S85. ${ }^{1} \mathrm{H}$ NMR spectrum (400 MHz, $\mathrm{CDCl}_{3}$ ) of Ni10.

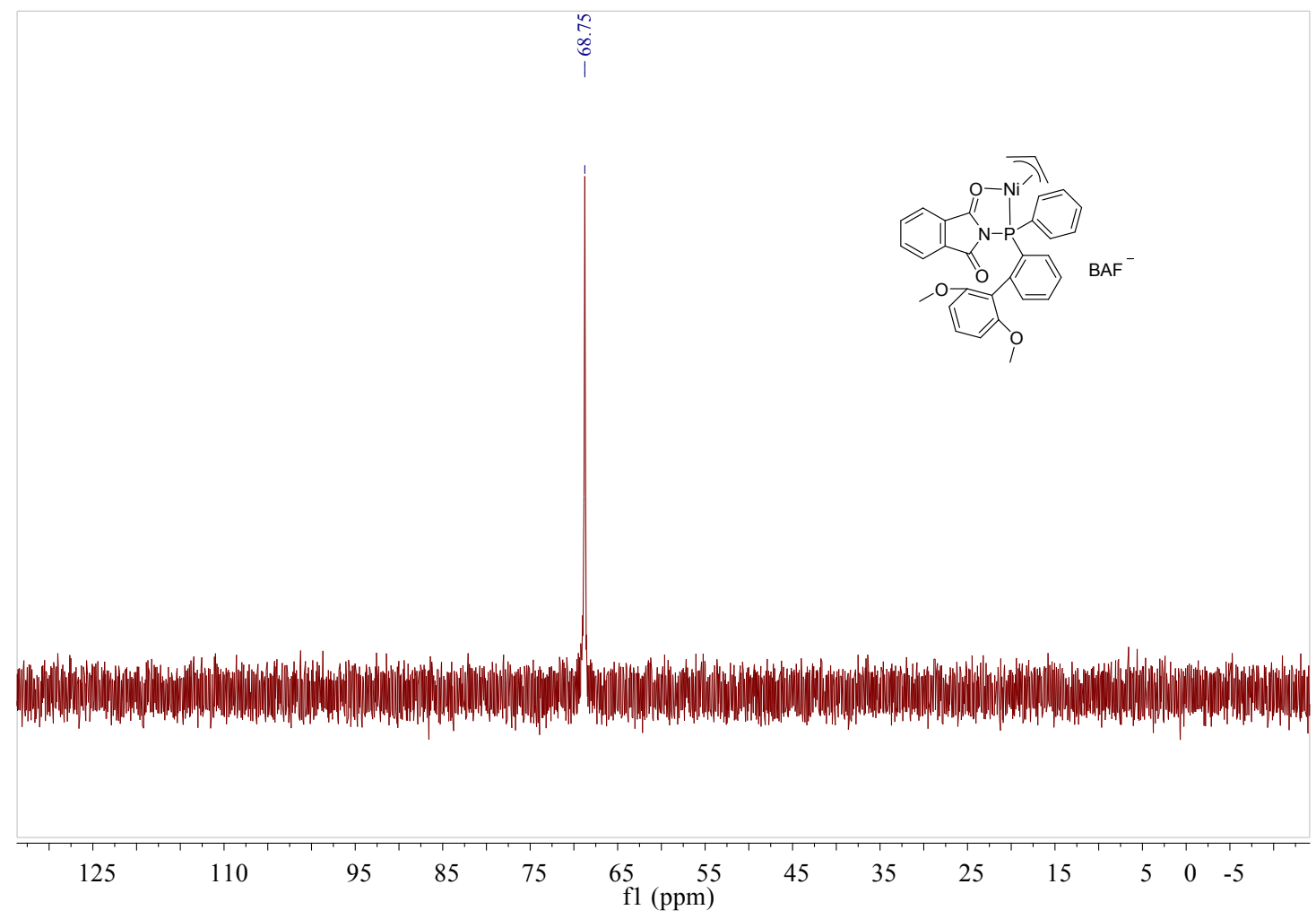

Figure S86. ${ }^{31} \mathrm{P}$ NMR spectrum $\left(\mathrm{CDCl}_{3}\right)$ of Ni10. 


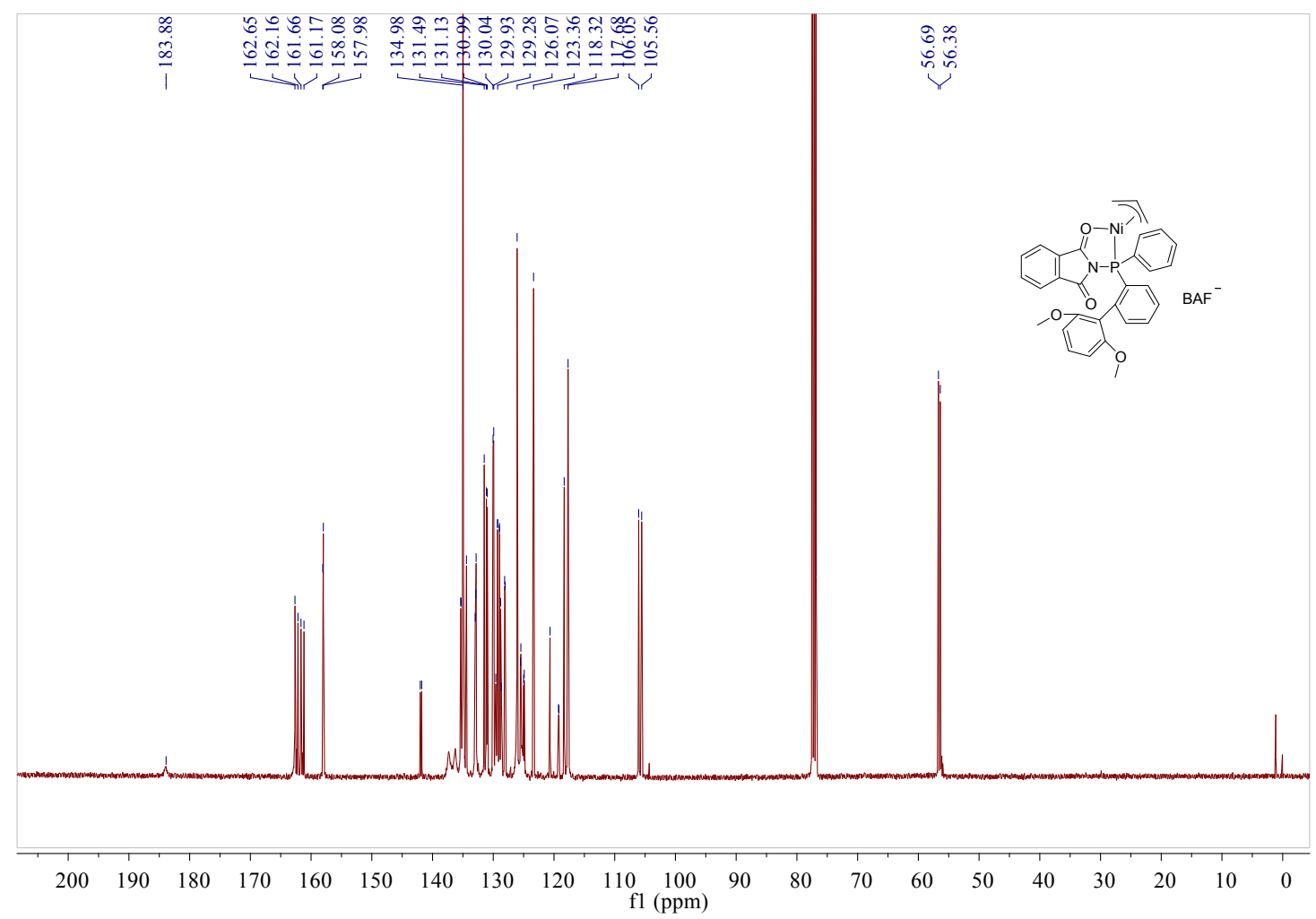

Figure S87. ${ }^{13} \mathrm{C}$ NMR spectrum in $\mathrm{CDCl}_{3}$ of Ni10.

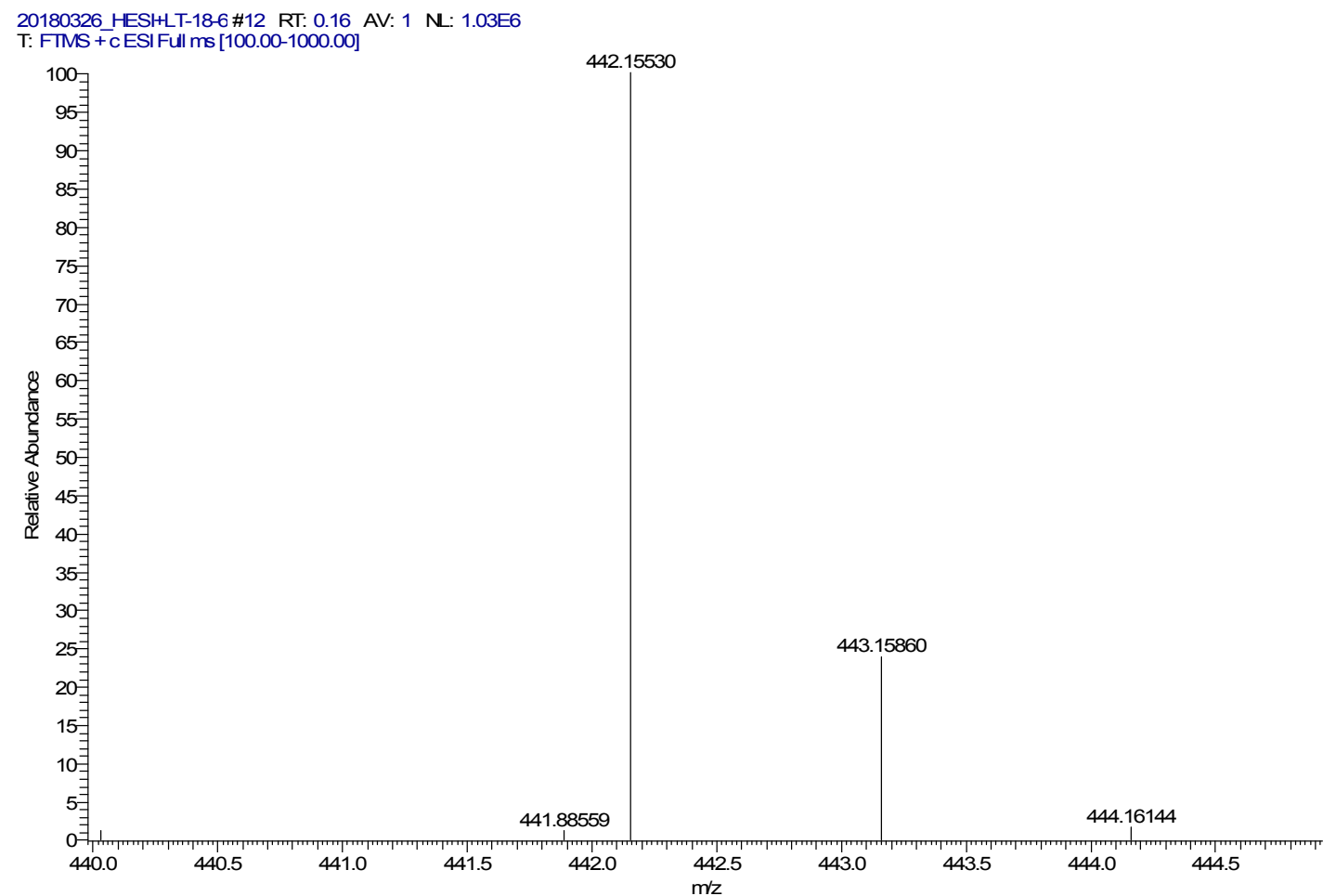

Figure S88. ESI-MS of L1. 


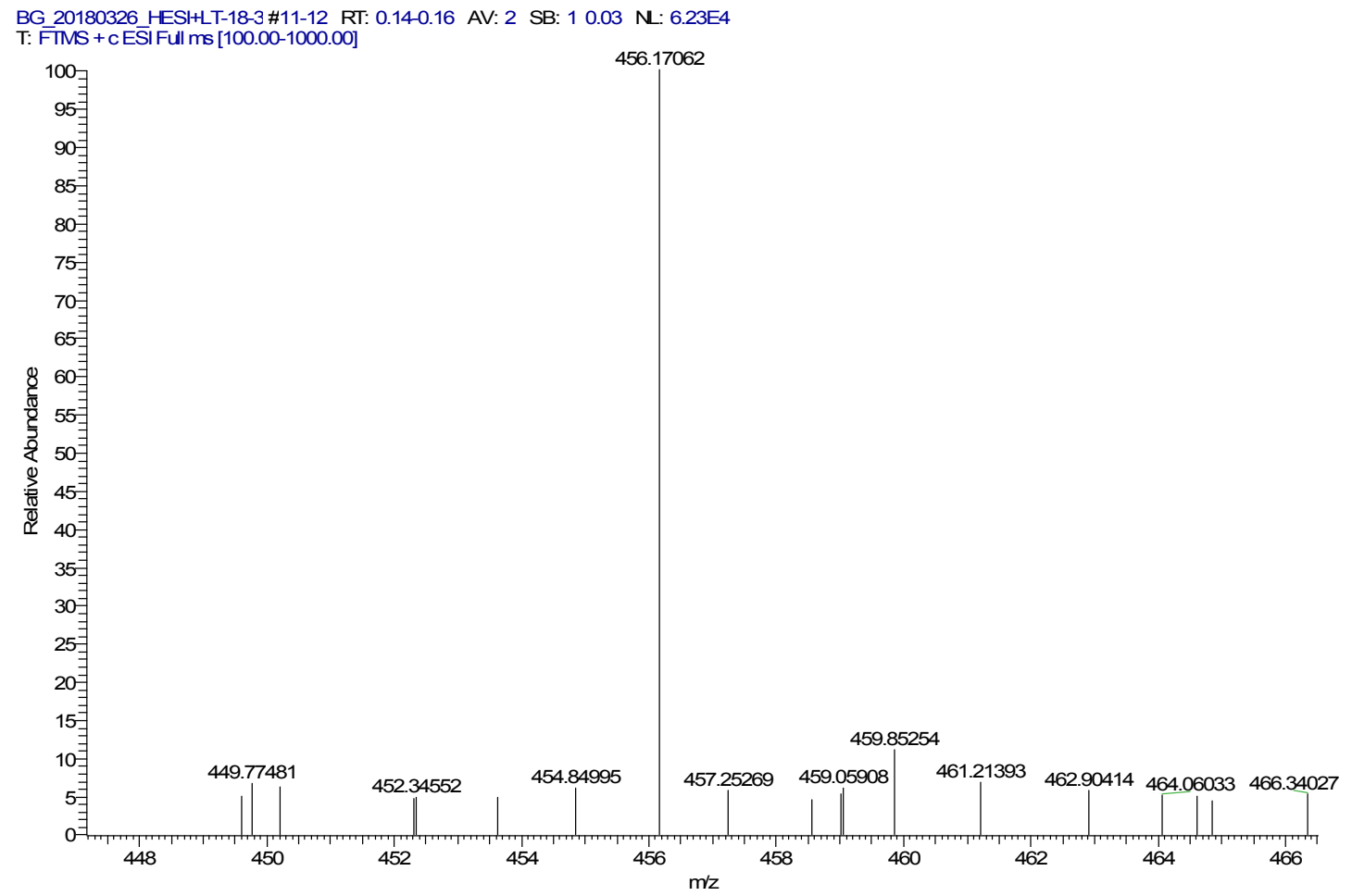

Figure S89. ESI-MS of L2.

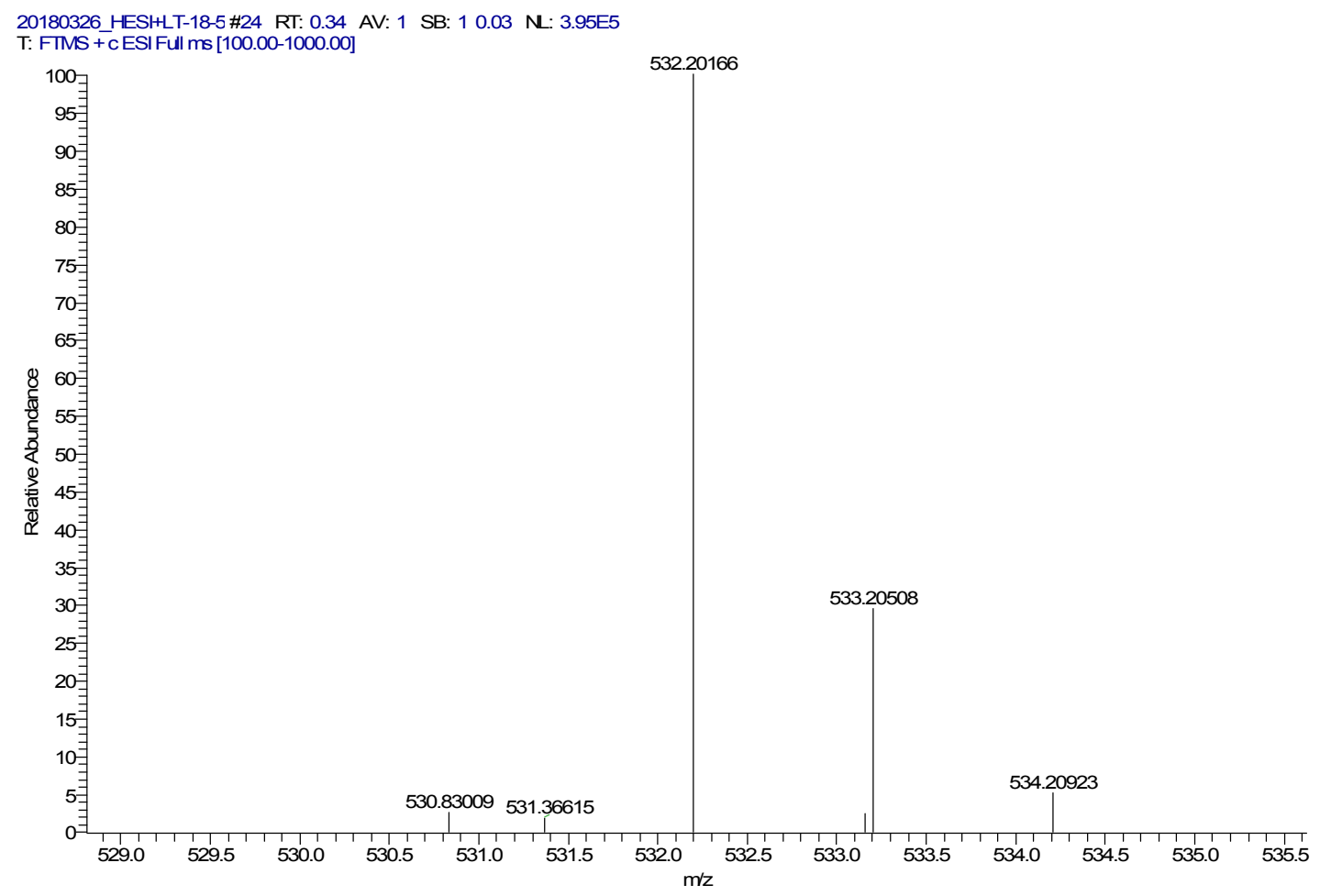

Figure S90. ESI-MS of L3. 
Figure S91. ESI-MS of L4.

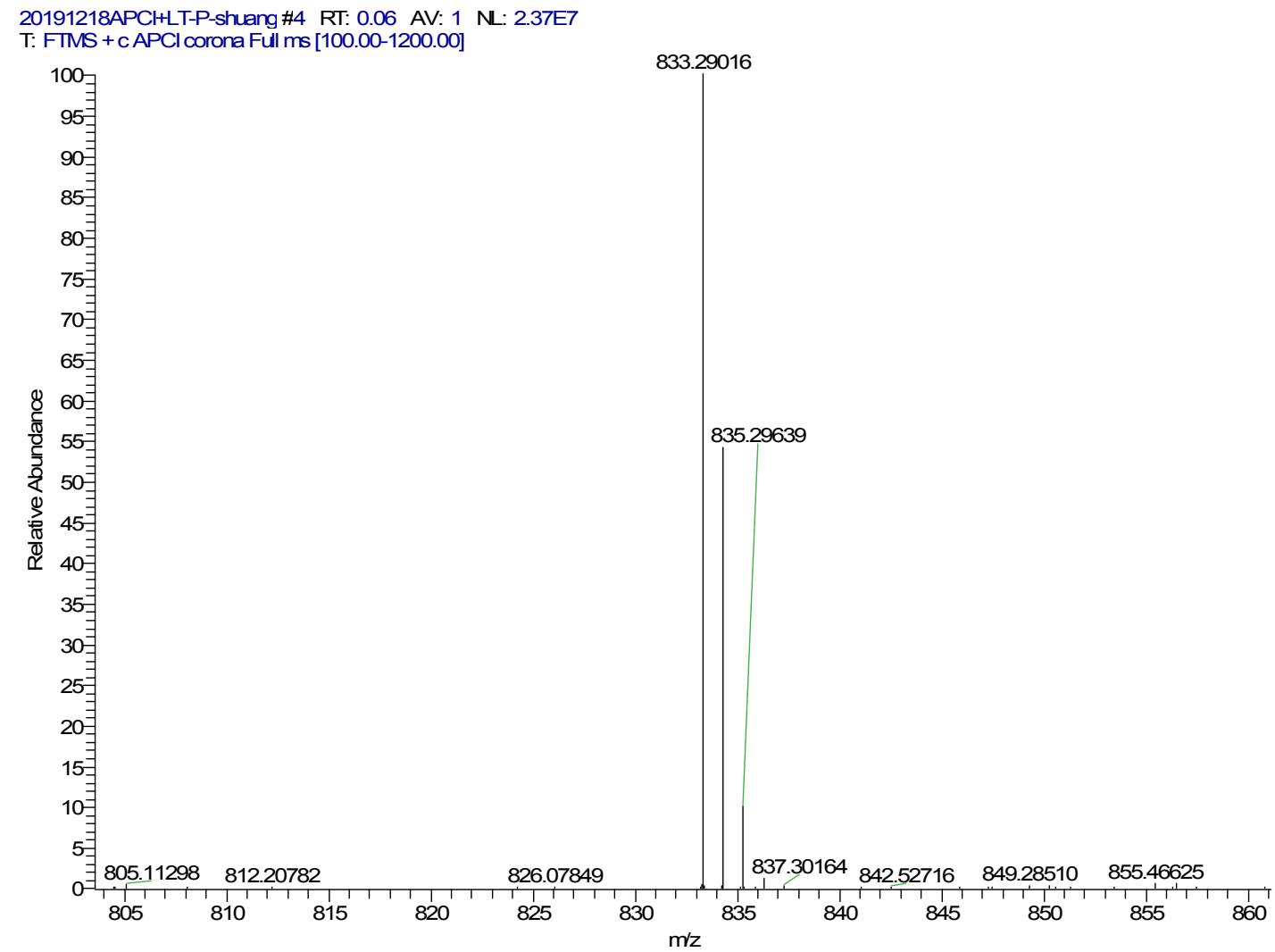

Figure S92. ESI-MS of L5. 


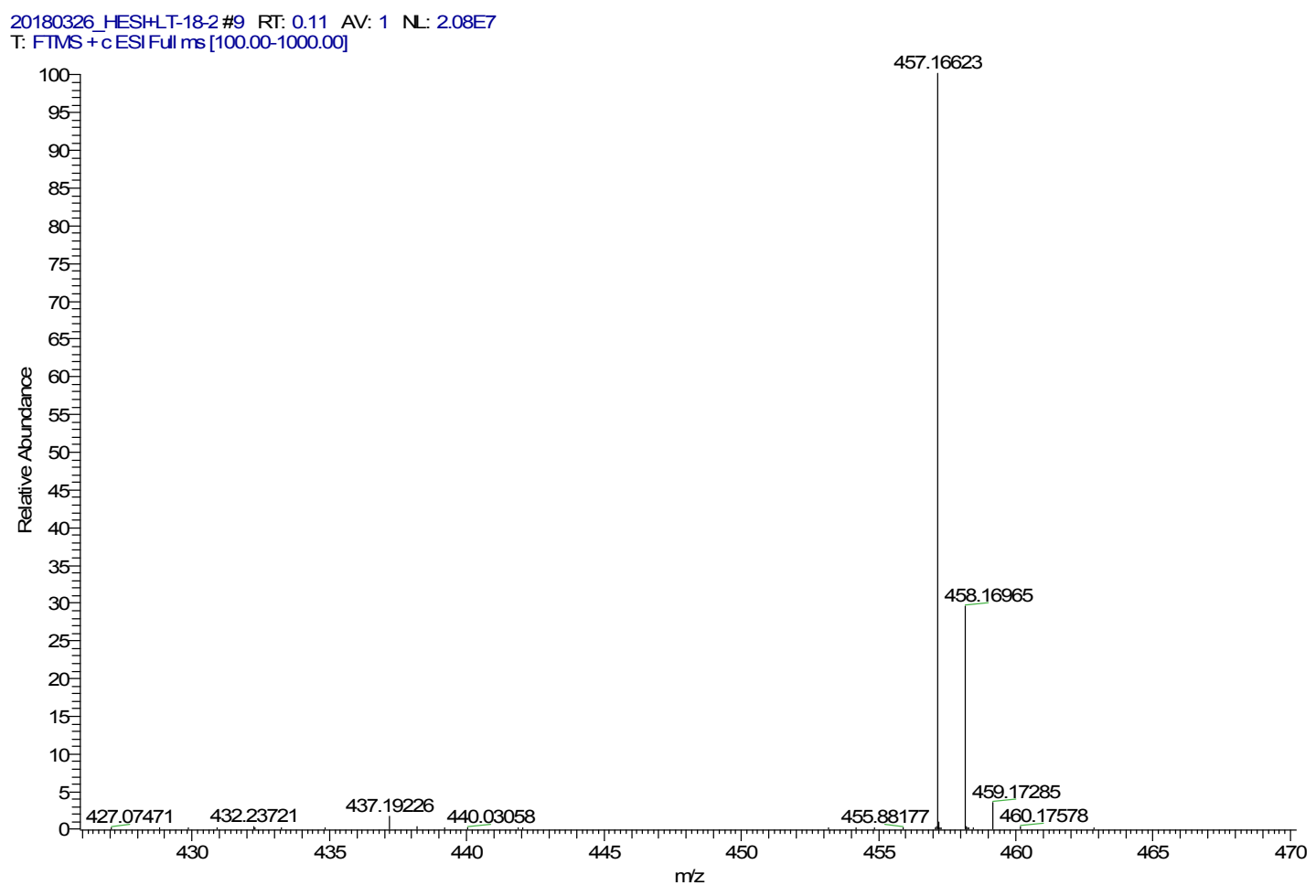

Figure S93. ESI-MS of L6

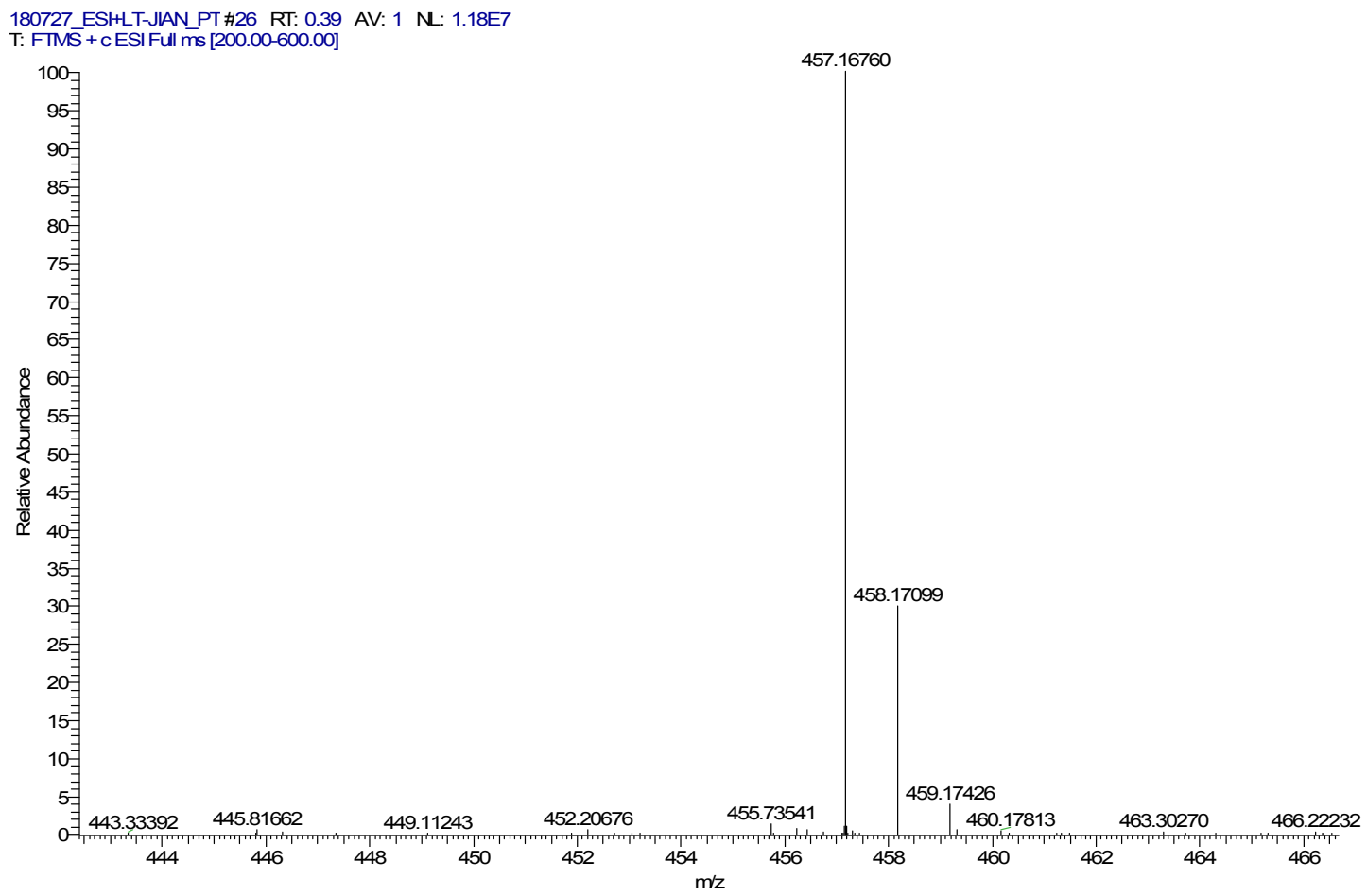

Figure S94. ESI-MS of L7 


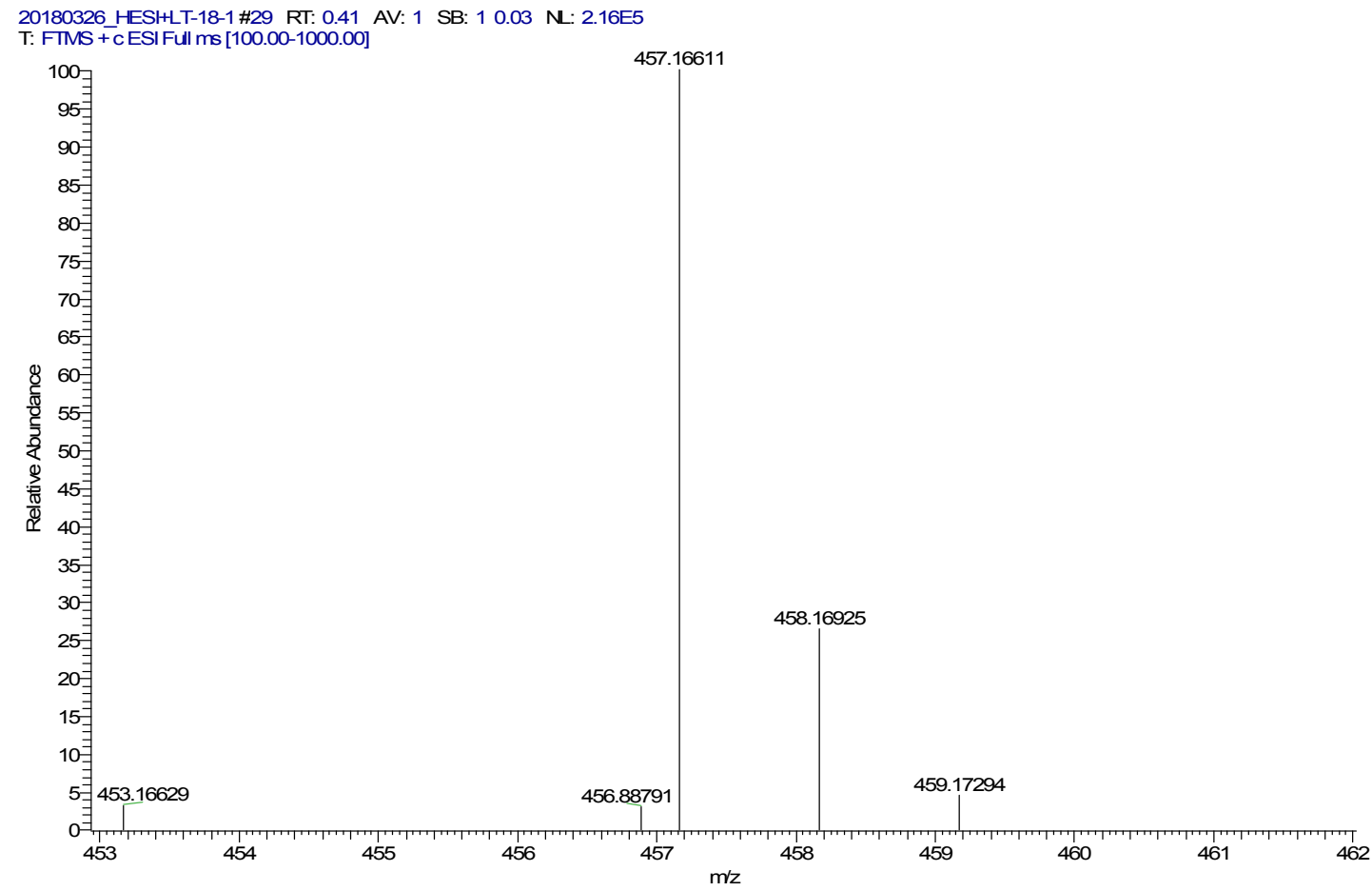

Figure S95. ESI-MS of L8.

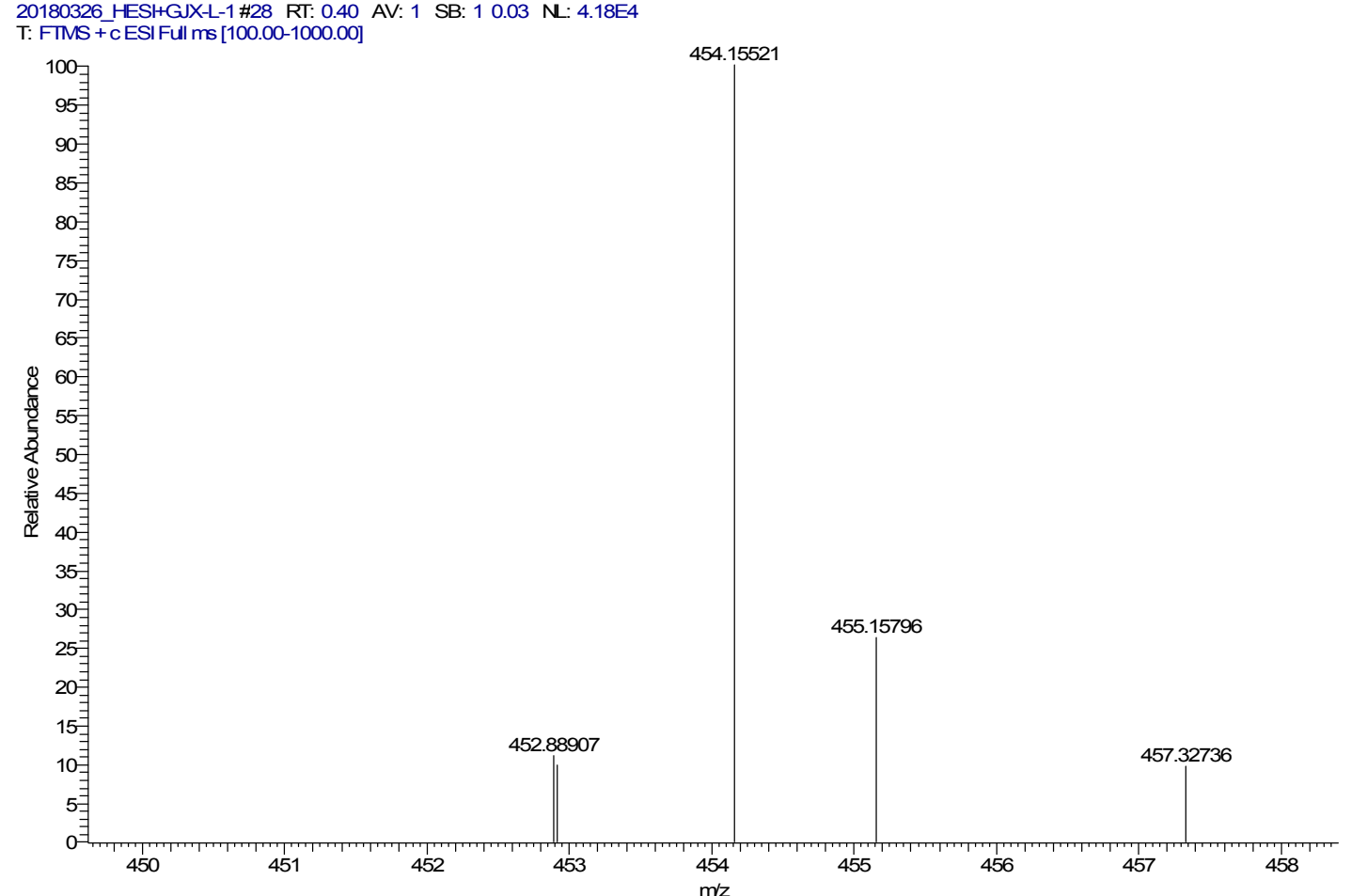

Figure S96. ESI-MS of L9. 


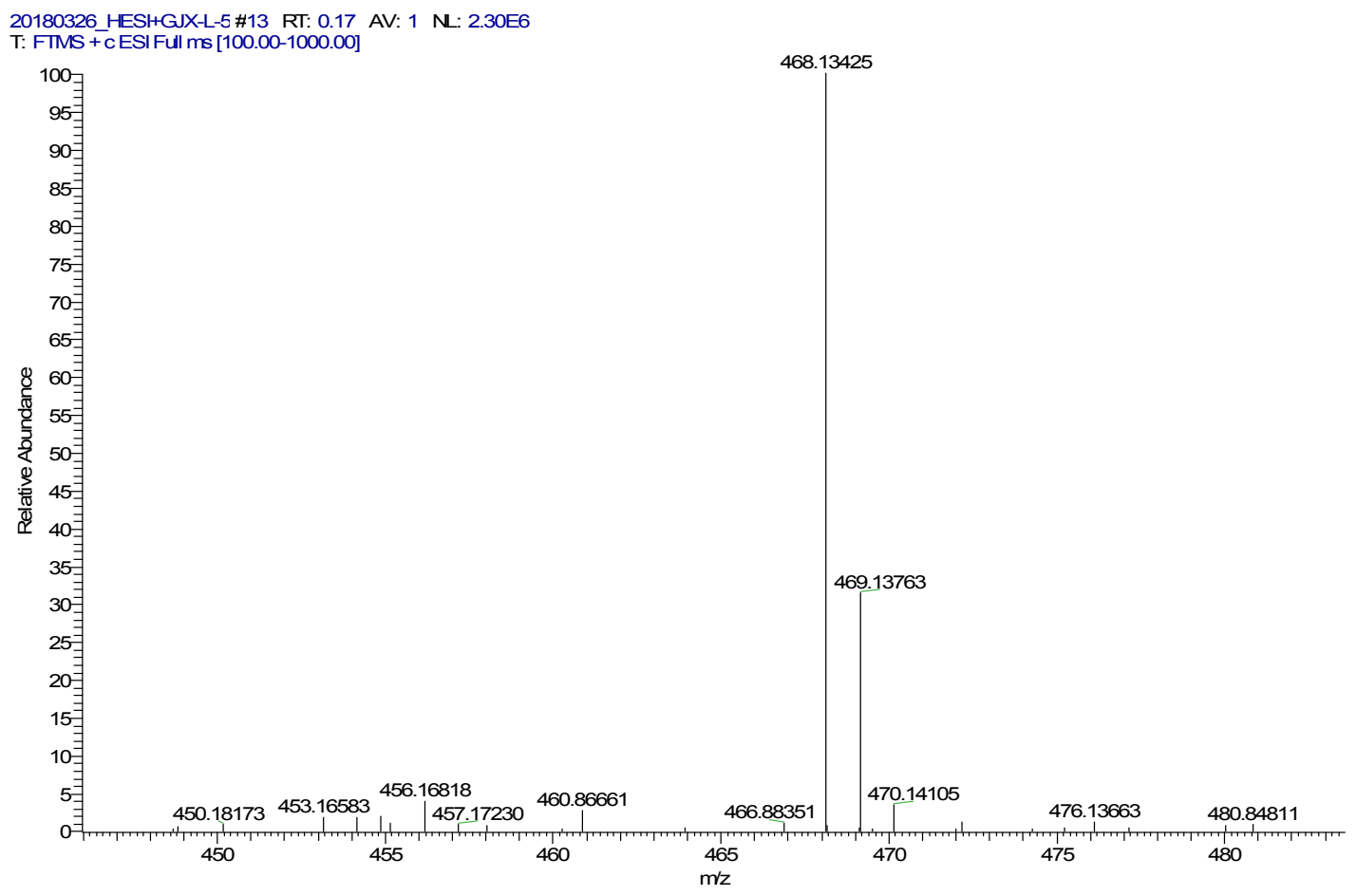

Figure S97. ESI-MS of L10. 


\section{NMR spectra of copolymers.}

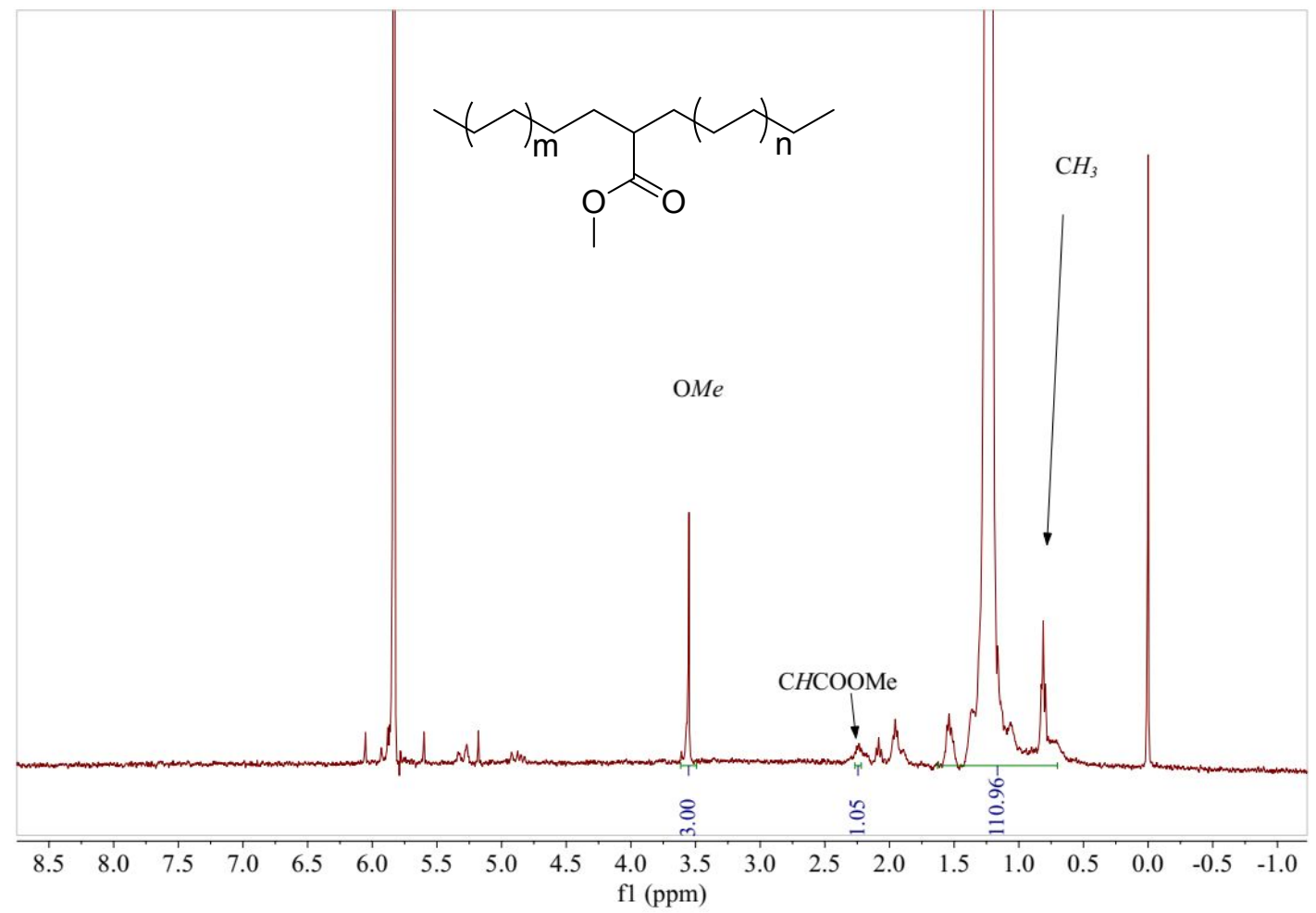

Figure S98. ${ }^{1} \mathrm{H}$ NMR spectrum of the copolymer from table 2 , entry $1\left(\mathrm{C}_{2} \mathrm{D}_{2} \mathrm{Cl}_{4}, 120{ }^{\circ} \mathrm{C}\right)$.

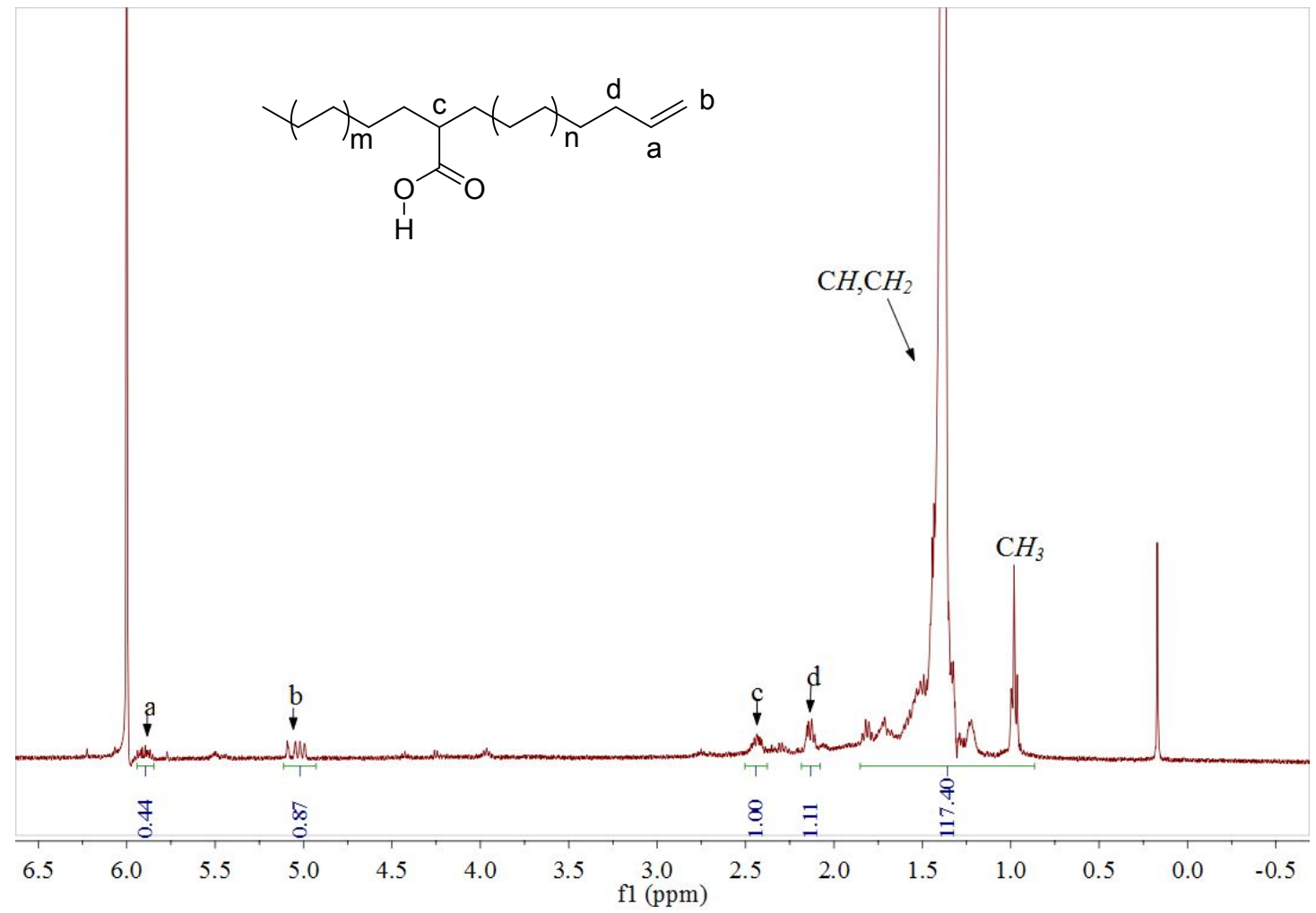

Figure S99. ${ }^{1} \mathrm{H}$ NMR spectrum of the copolymer from table 2 , entry $2\left(\mathrm{C}_{2} \mathrm{D}_{2} \mathrm{Cl}_{4}, 120{ }^{\circ} \mathrm{C}\right)$. 


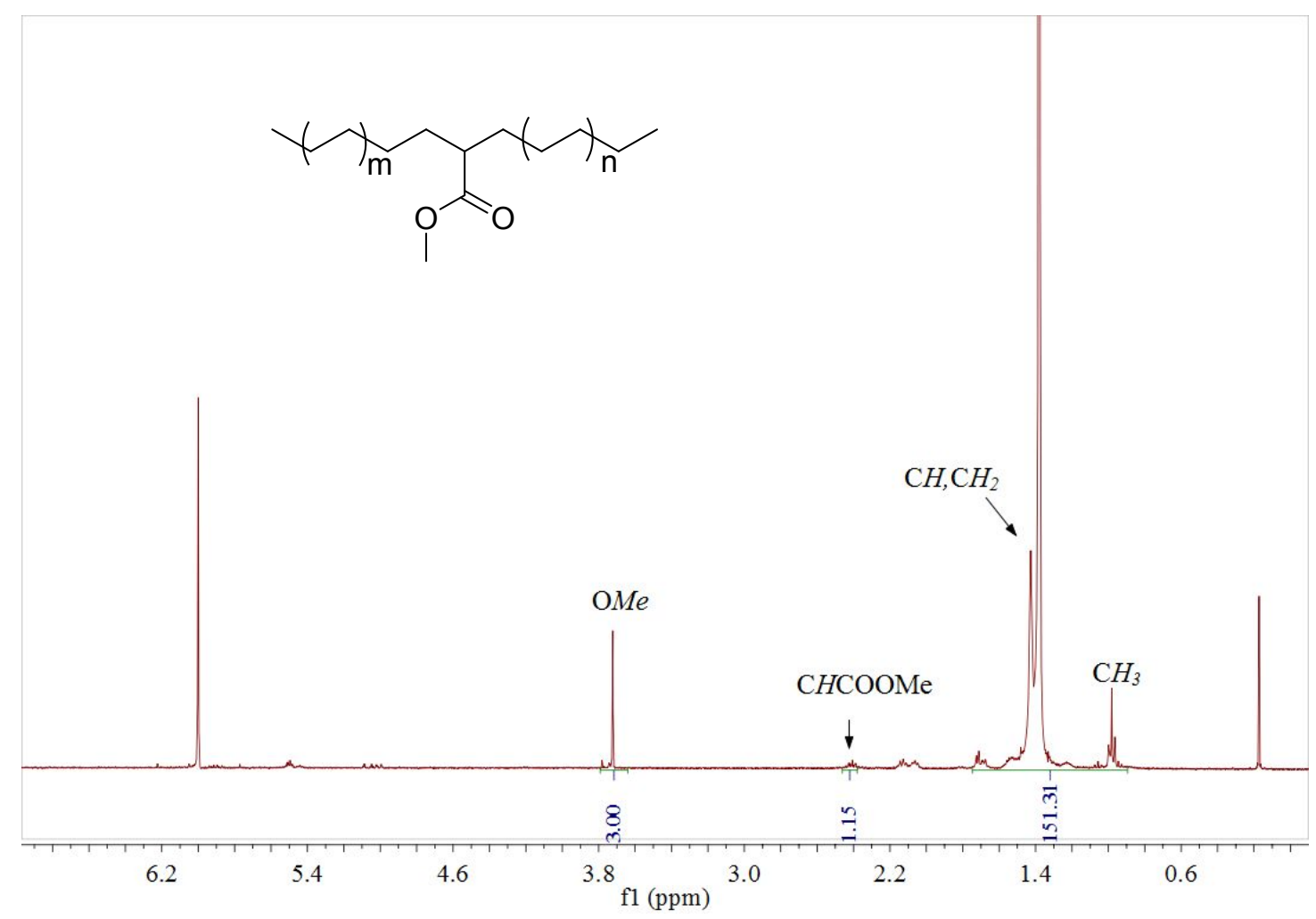

Figure S100. ${ }^{1} \mathrm{H}$ NMR spectrum of the copolymer from table 2, entry $3\left(\mathrm{C}_{2} \mathrm{D}_{2} \mathrm{Cl}_{4}, 120^{\circ} \mathrm{C}\right)$.

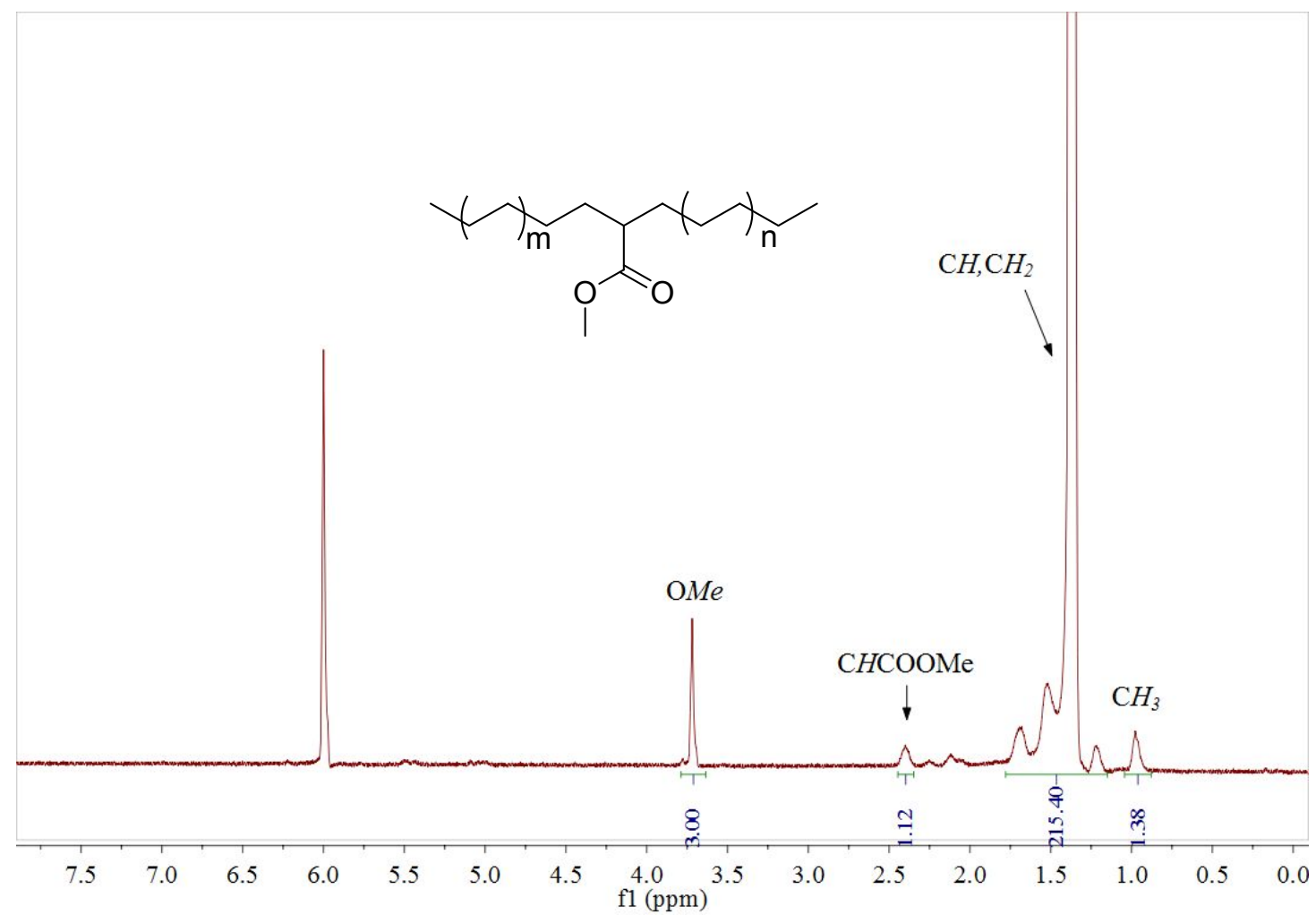

Figure S101. ${ }^{1} \mathrm{H}$ NMR spectrum of the copolymer from table 2 , entry $4\left(\mathrm{C}_{2} \mathrm{D}_{2} \mathrm{Cl}_{4}, 120{ }^{\circ} \mathrm{C}\right)$. 


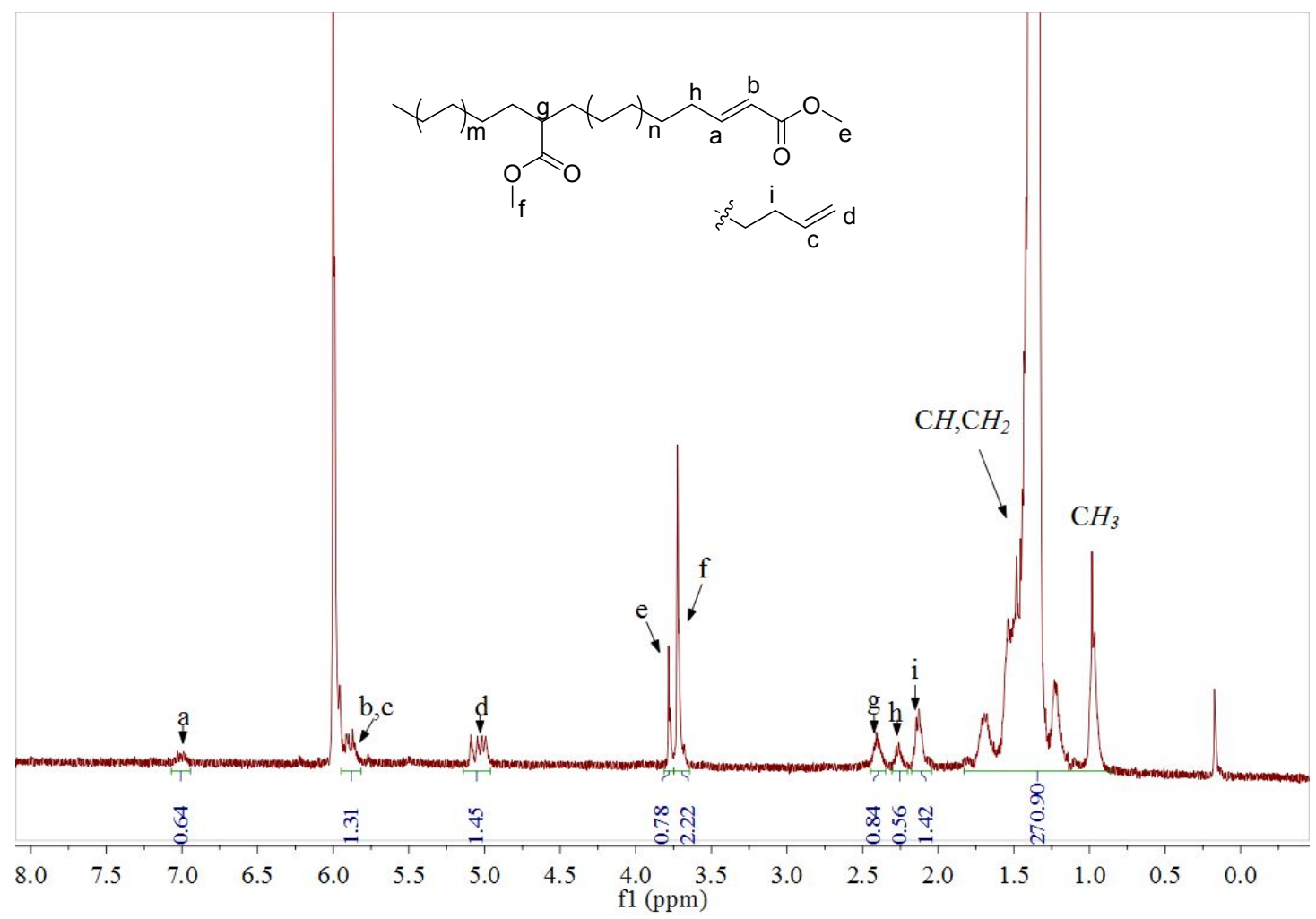

Figure S102. ${ }^{1} \mathrm{H}$ NMR spectrum of the copolymer from table 2, entry $5\left(\mathrm{C}_{2} \mathrm{D}_{2} \mathrm{Cl}_{4}, 120^{\circ} \mathrm{C}\right)$.

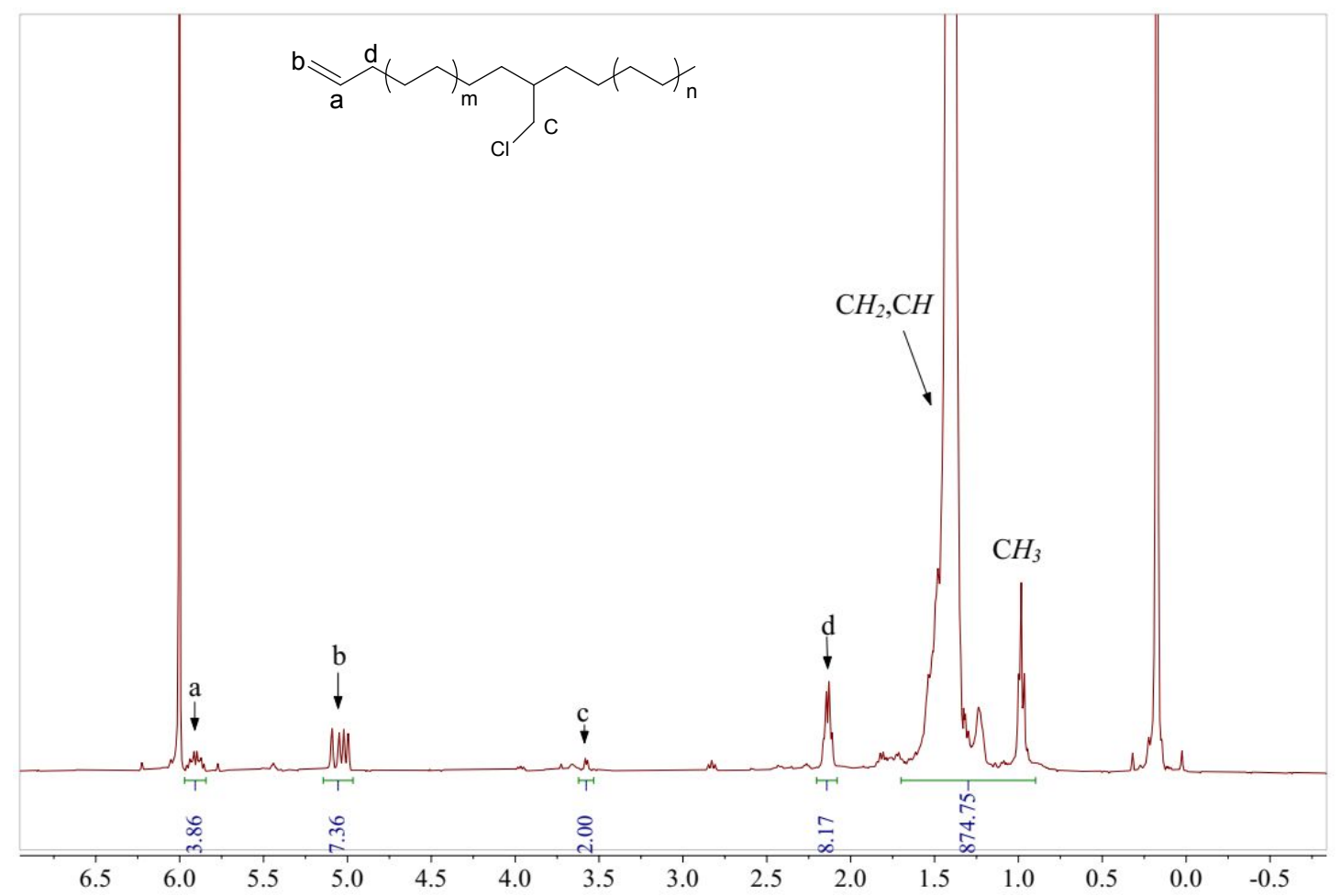

Figure S103. ${ }^{1} \mathrm{H}$ NMR spectrum of the copolymer from table 2, entry $6\left(\mathrm{C}_{2} \mathrm{D}_{2} \mathrm{Cl}_{4}, 120{ }^{\circ} \mathrm{C}\right)$. 


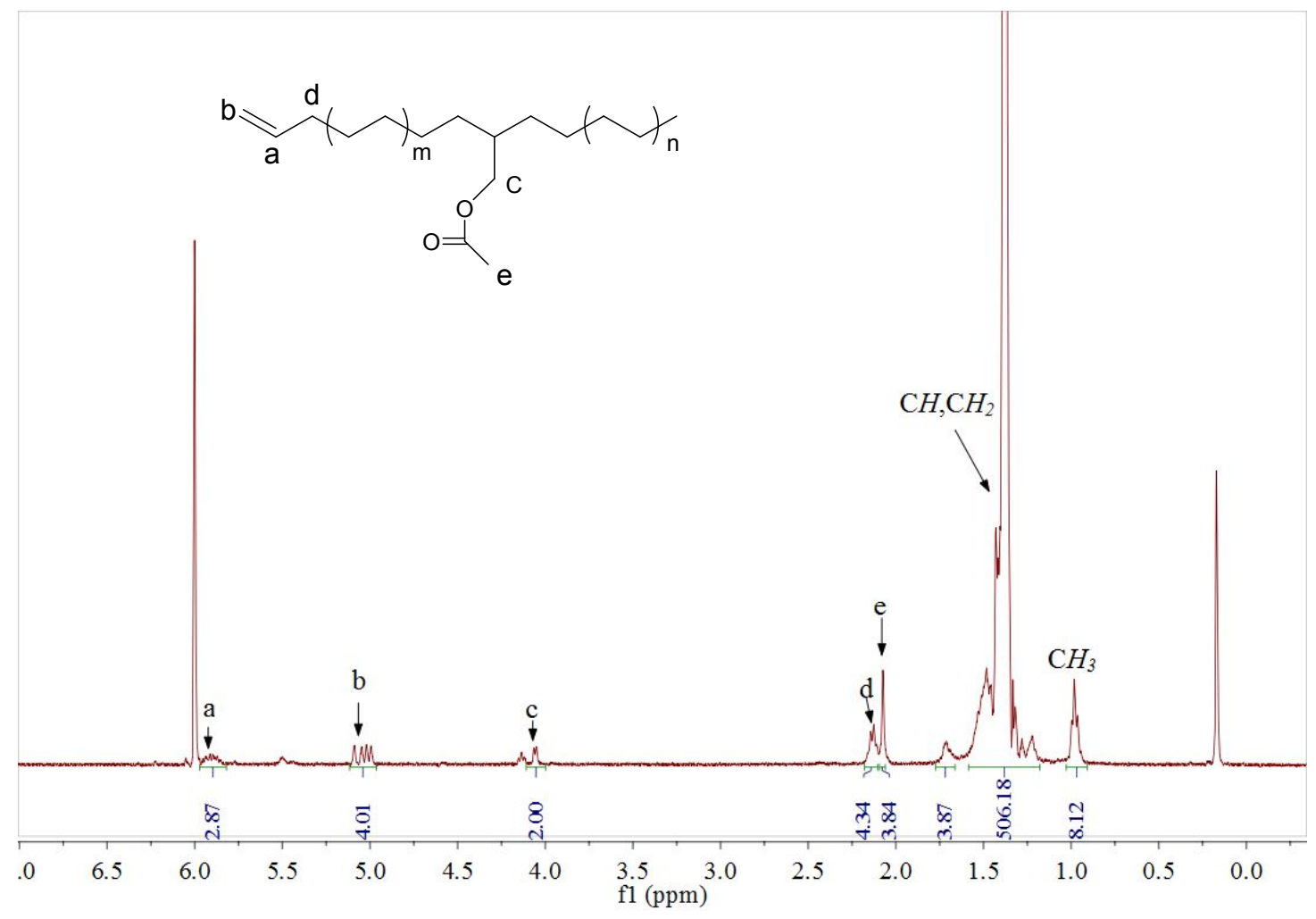

Figure S104. ${ }^{1} \mathrm{H}$ NMR spectrum of the copolymer from table 2 , entry $8\left(\mathrm{C}_{2} \mathrm{D}_{2} \mathrm{Cl}_{4}, 120^{\circ} \mathrm{C}\right)$.

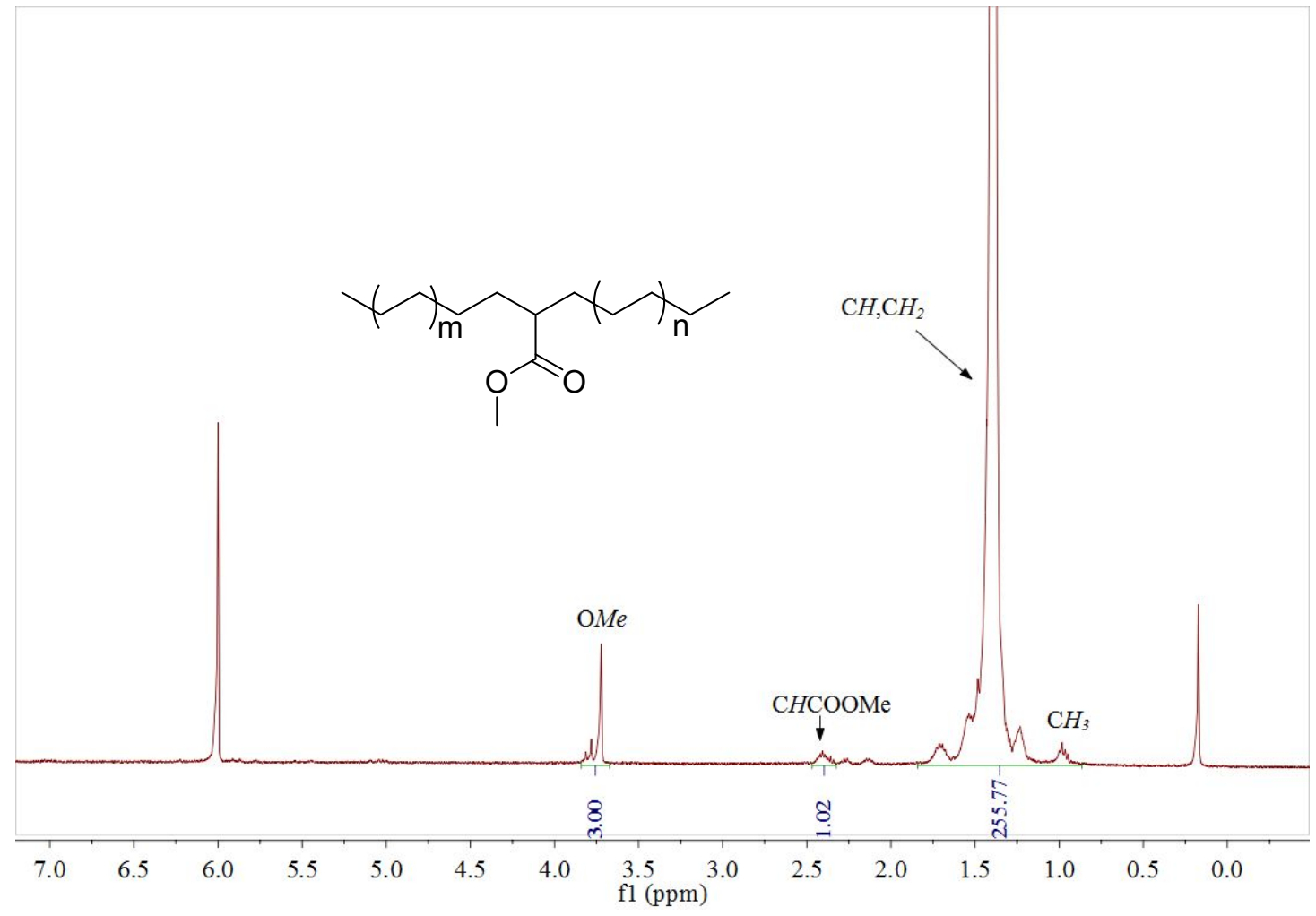

Figure S105. ${ }^{1} \mathrm{H}$ NMR spectrum of the copolymer from table 2 , entry $9\left(\mathrm{C}_{2} \mathrm{D}_{2} \mathrm{Cl}_{4}, 120{ }^{\circ} \mathrm{C}\right)$. 


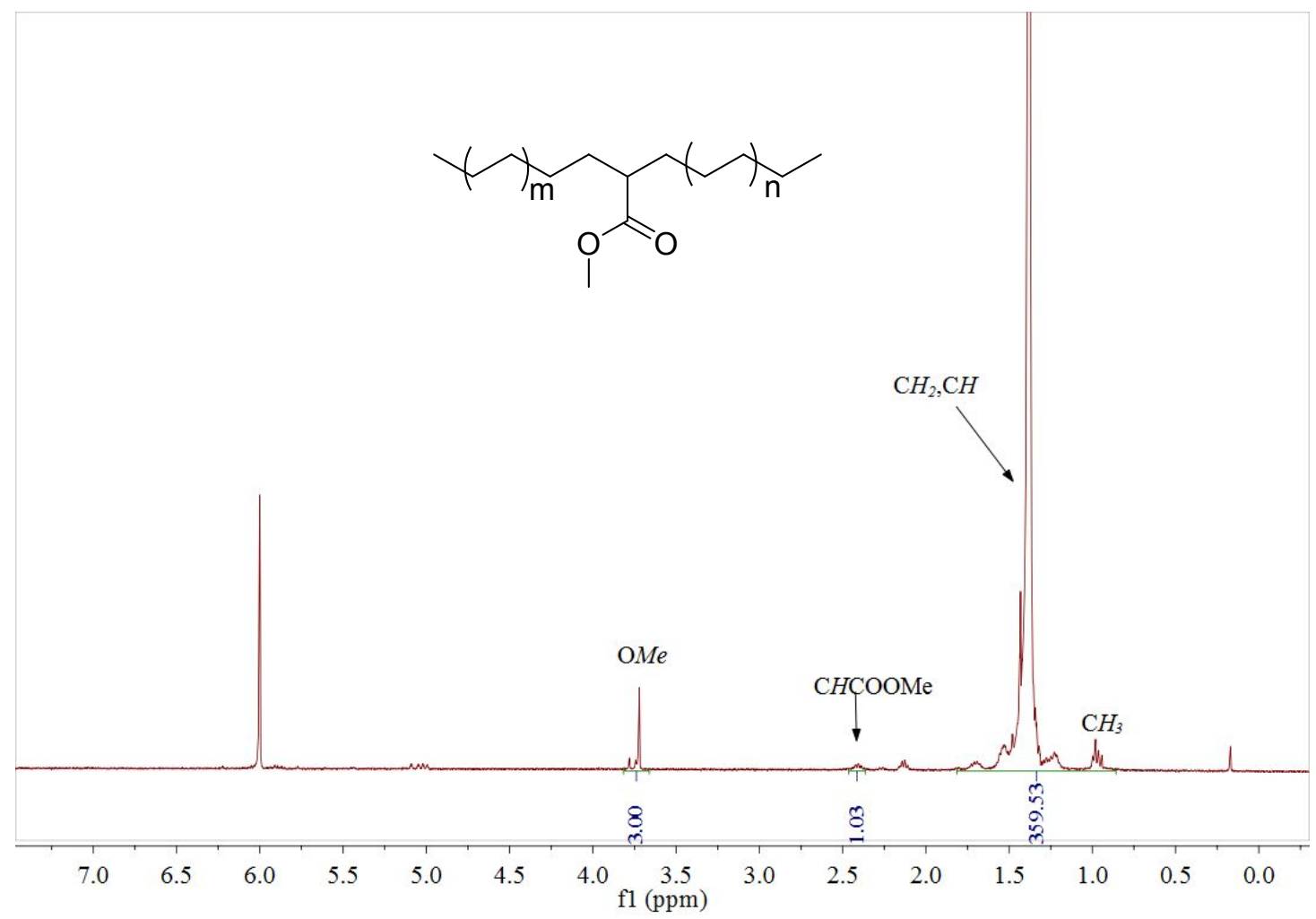

Figure S106. ${ }^{1} \mathrm{H}$ NMR spectrum of the copolymer from table 2, entry $10\left(\mathrm{C}_{2} \mathrm{D}_{2} \mathrm{Cl}_{4}, 120^{\circ} \mathrm{C}\right)$.

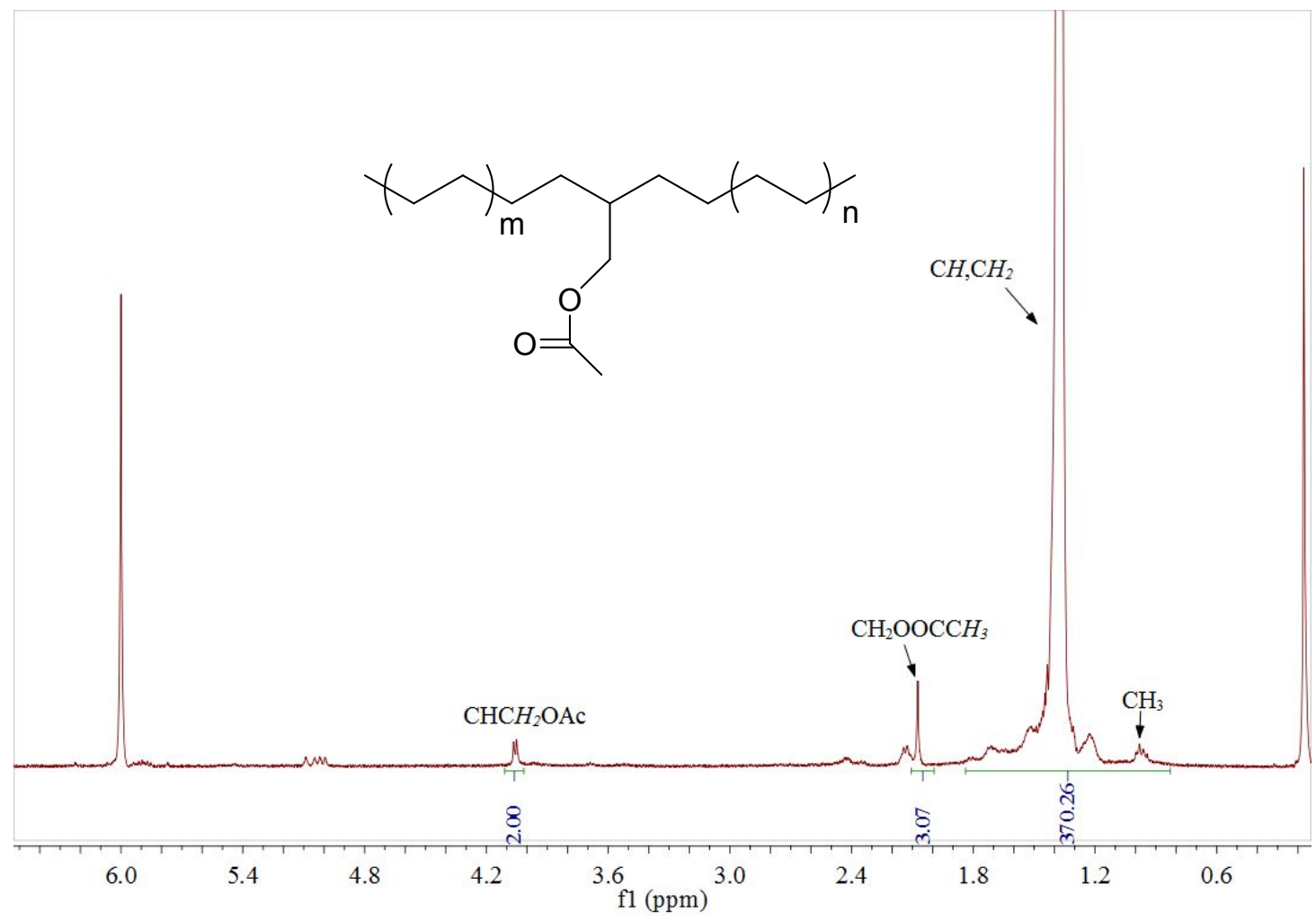

Figure S107. ${ }^{1} \mathrm{H}$ NMR spectrum of the copolymer from table 2 , entry $11\left(\mathrm{C}_{2} \mathrm{D}_{2} \mathrm{Cl}_{4}, 120{ }^{\circ} \mathrm{C}\right)$. 


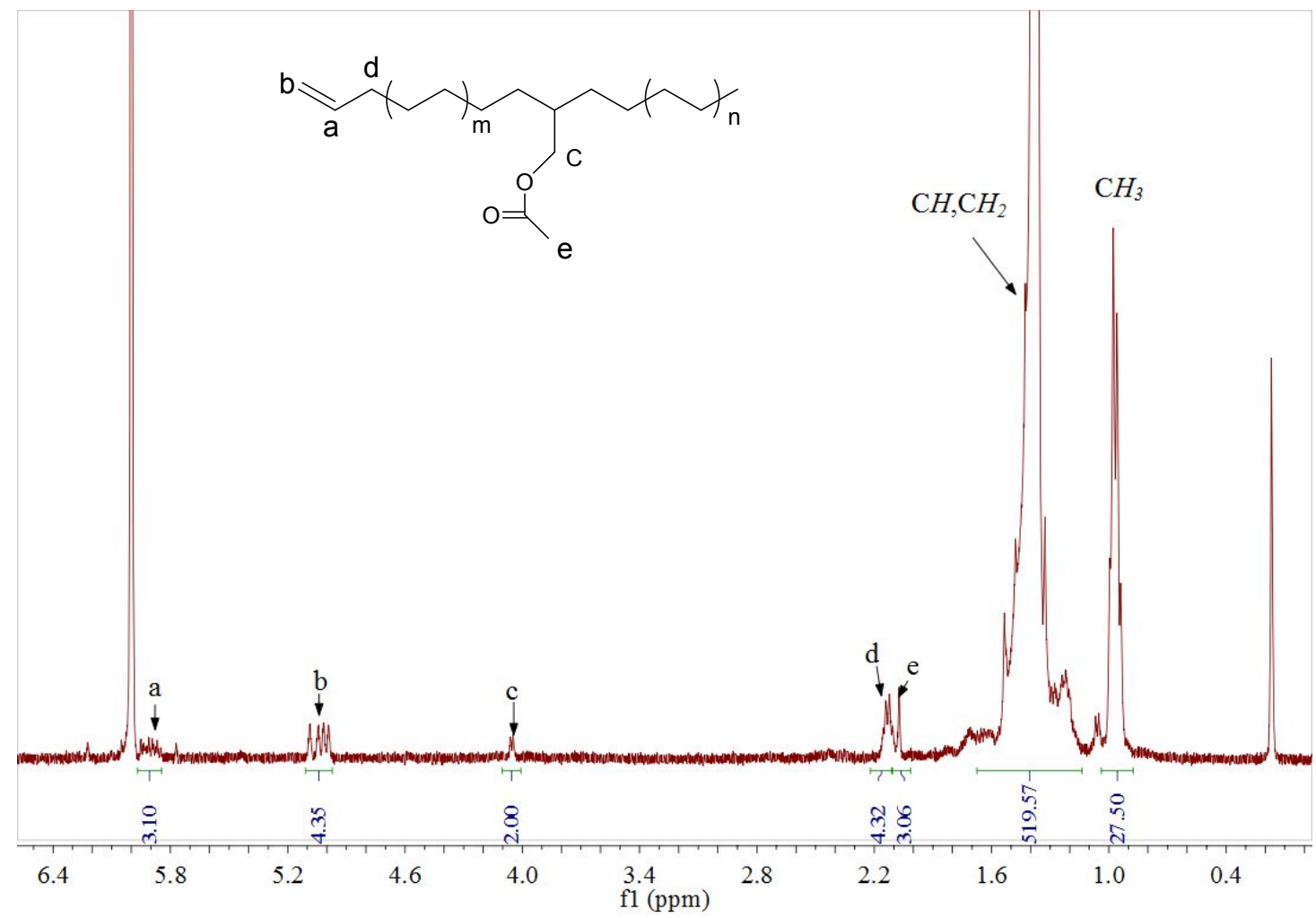

Figure S108. ${ }^{1} \mathrm{H}$ NMR spectrum of the copolymer from table 2, entry $12\left(\mathrm{C}_{2} \mathrm{D}_{2} \mathrm{Cl}_{4}, 12{ }^{\circ} \mathrm{C}\right)$.

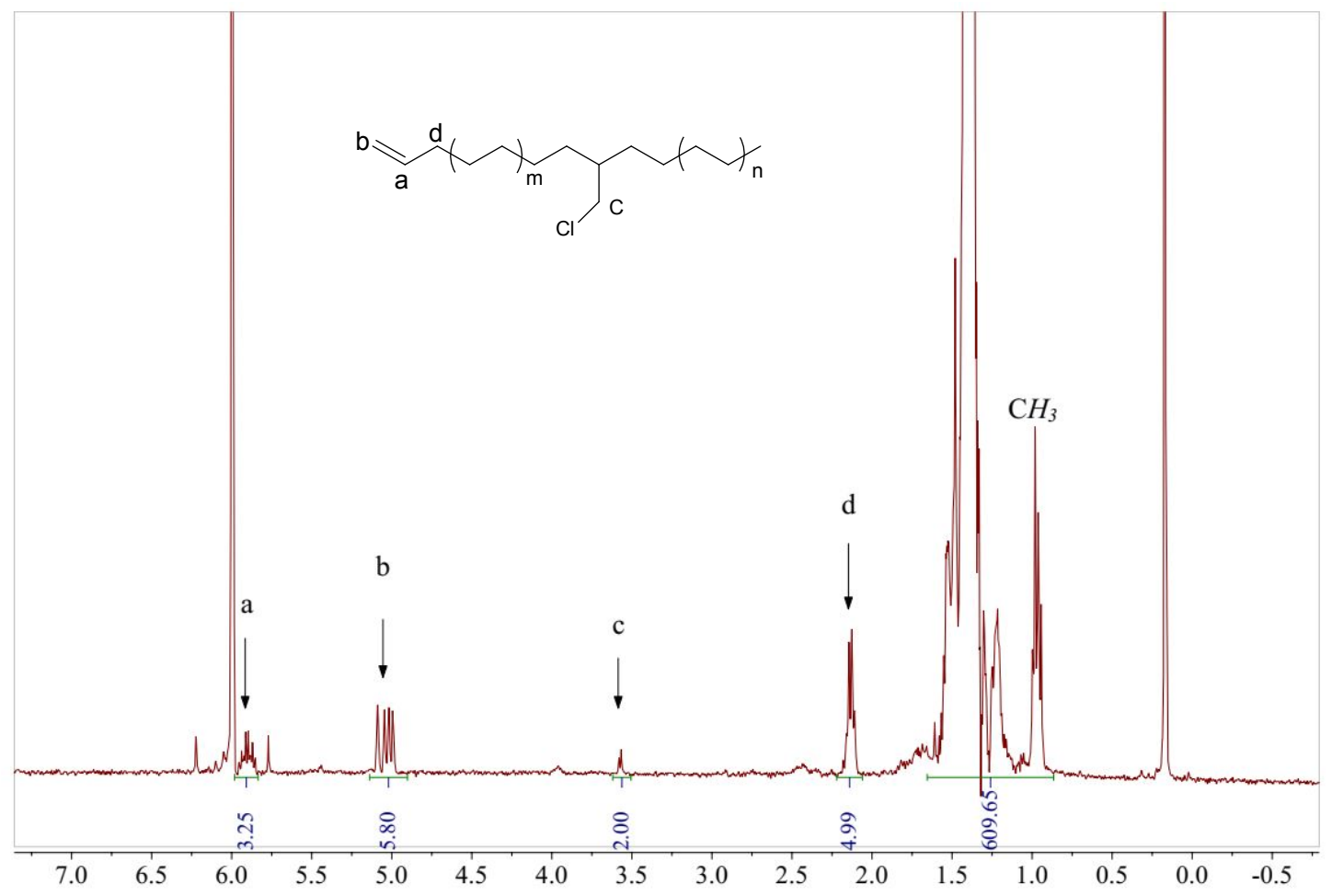

Figure S109. ${ }^{1} \mathrm{H}$ NMR spectrum of the copolymer from table 2, entry $13\left(\mathrm{C}_{2} \mathrm{D}_{2} \mathrm{Cl}_{4}, 120{ }^{\circ} \mathrm{C}\right)$. 


\section{DSC of polymers.}

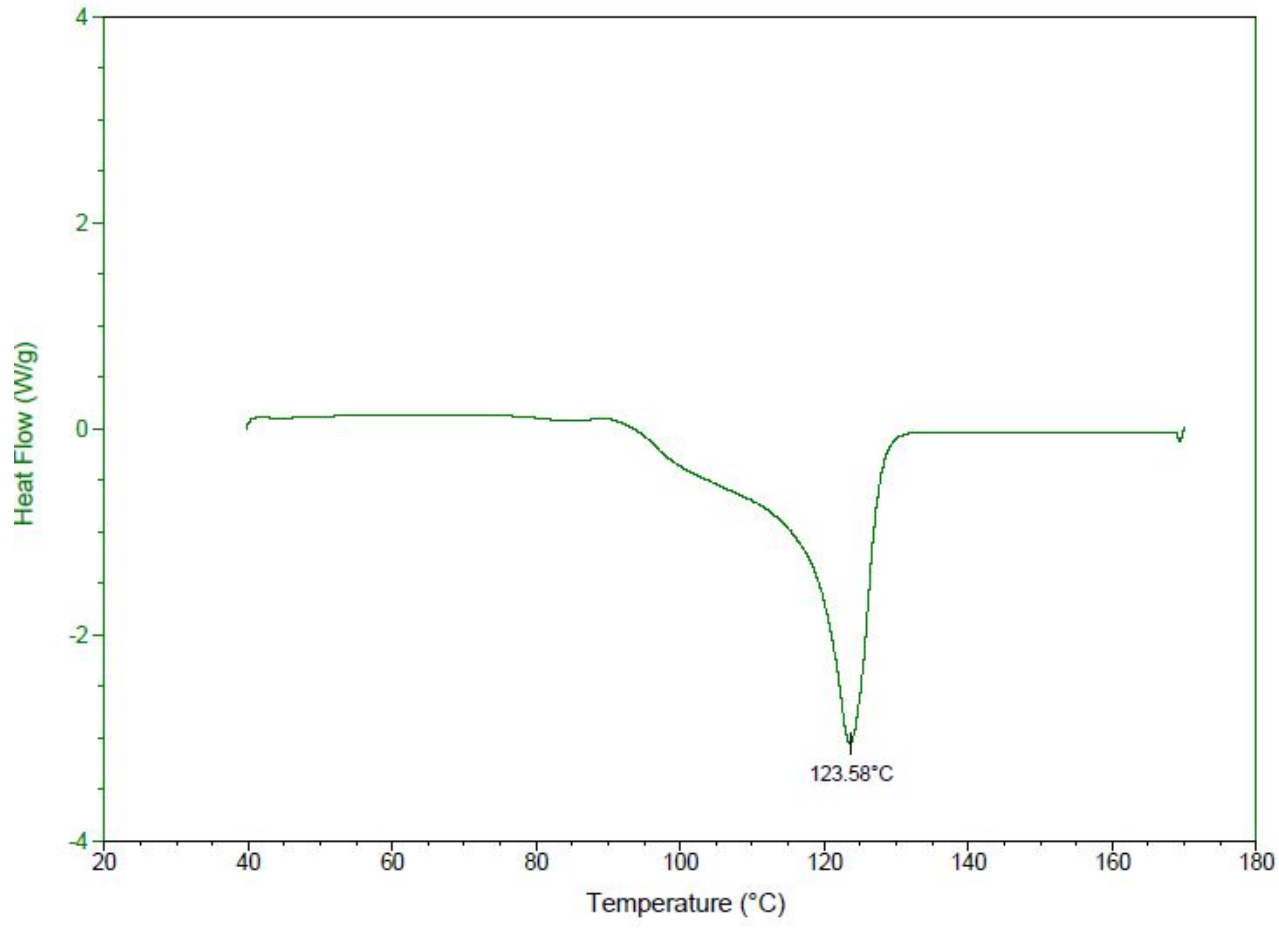

Figure S110. DSC of the polymer from table 1, entry 3.

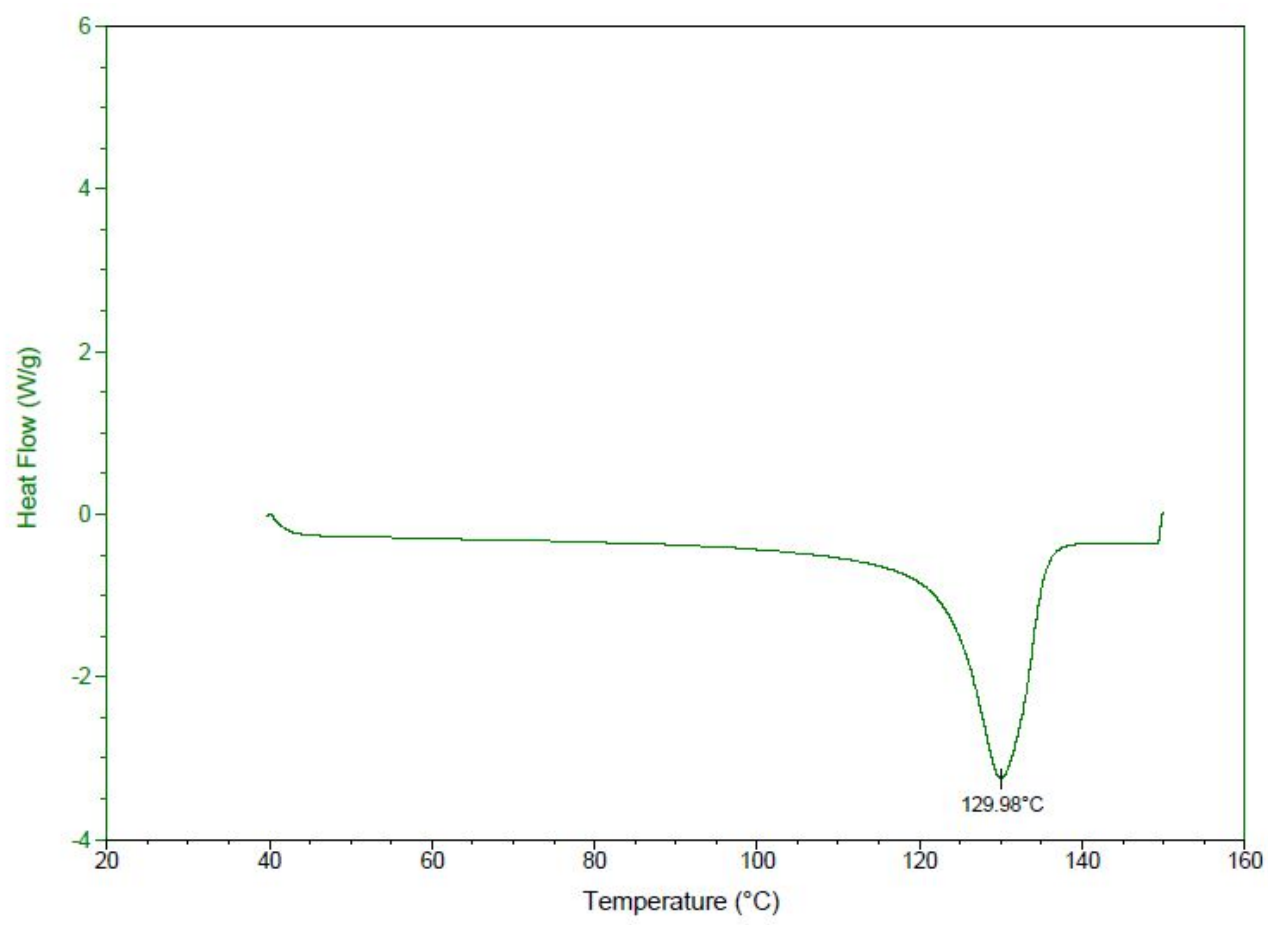

Figure S111. DSC of the polymer from table 1, entry 4. 


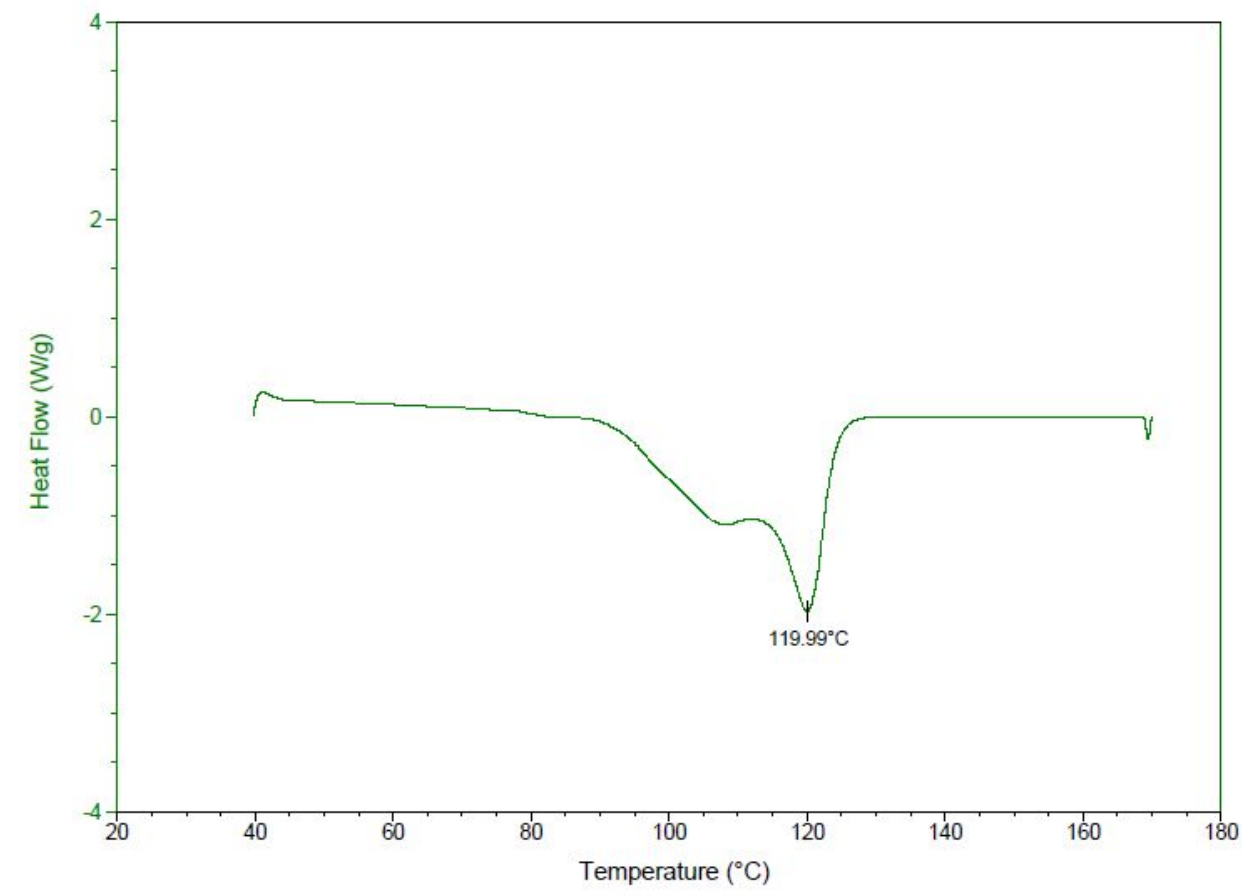

Figure S112. DSC of the polymer from table 1, entry 5.

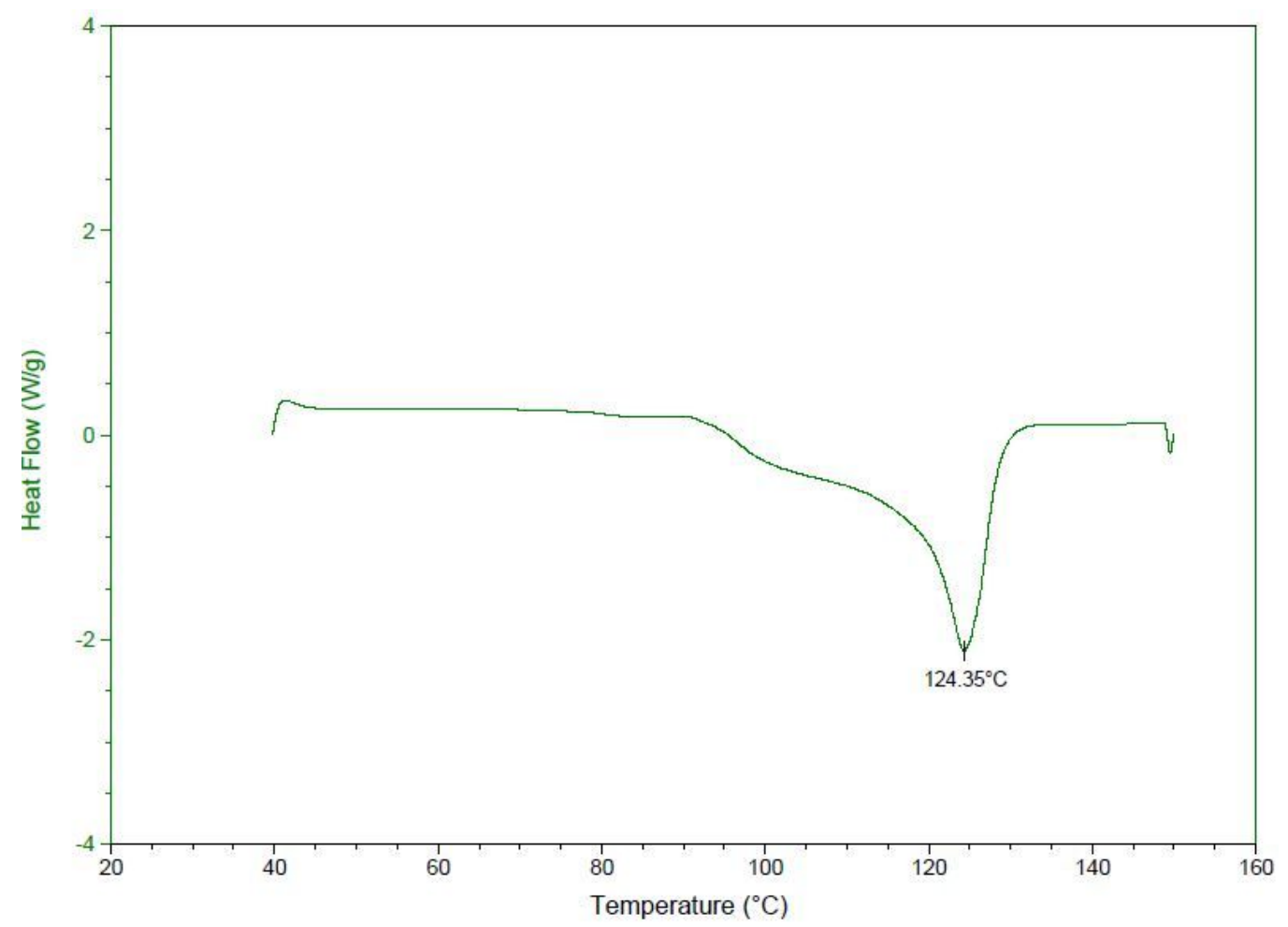

Figure S113. DSC of the polymer from table 1, entry 6. 


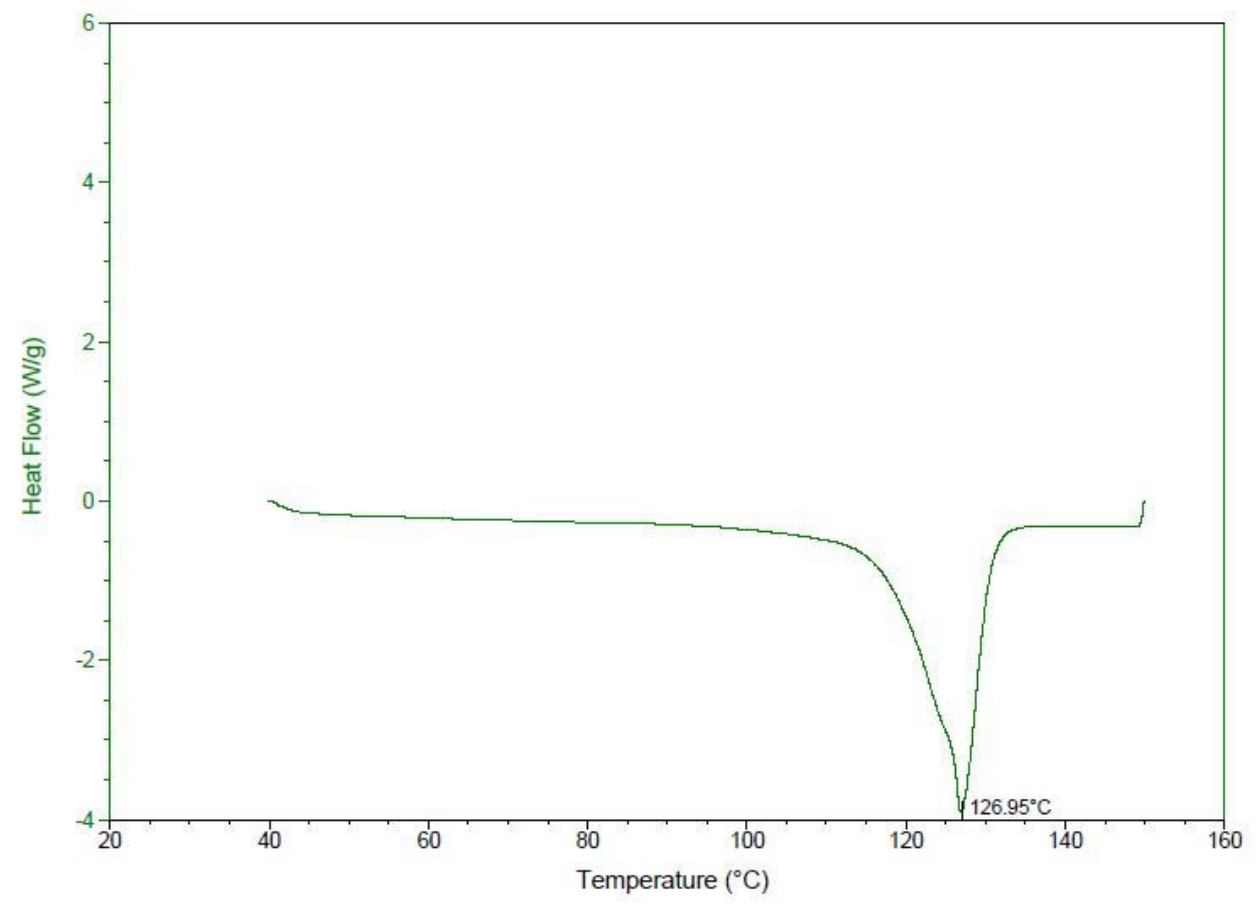

Figure S114. DSC of the polymer from table 1, entry 7.

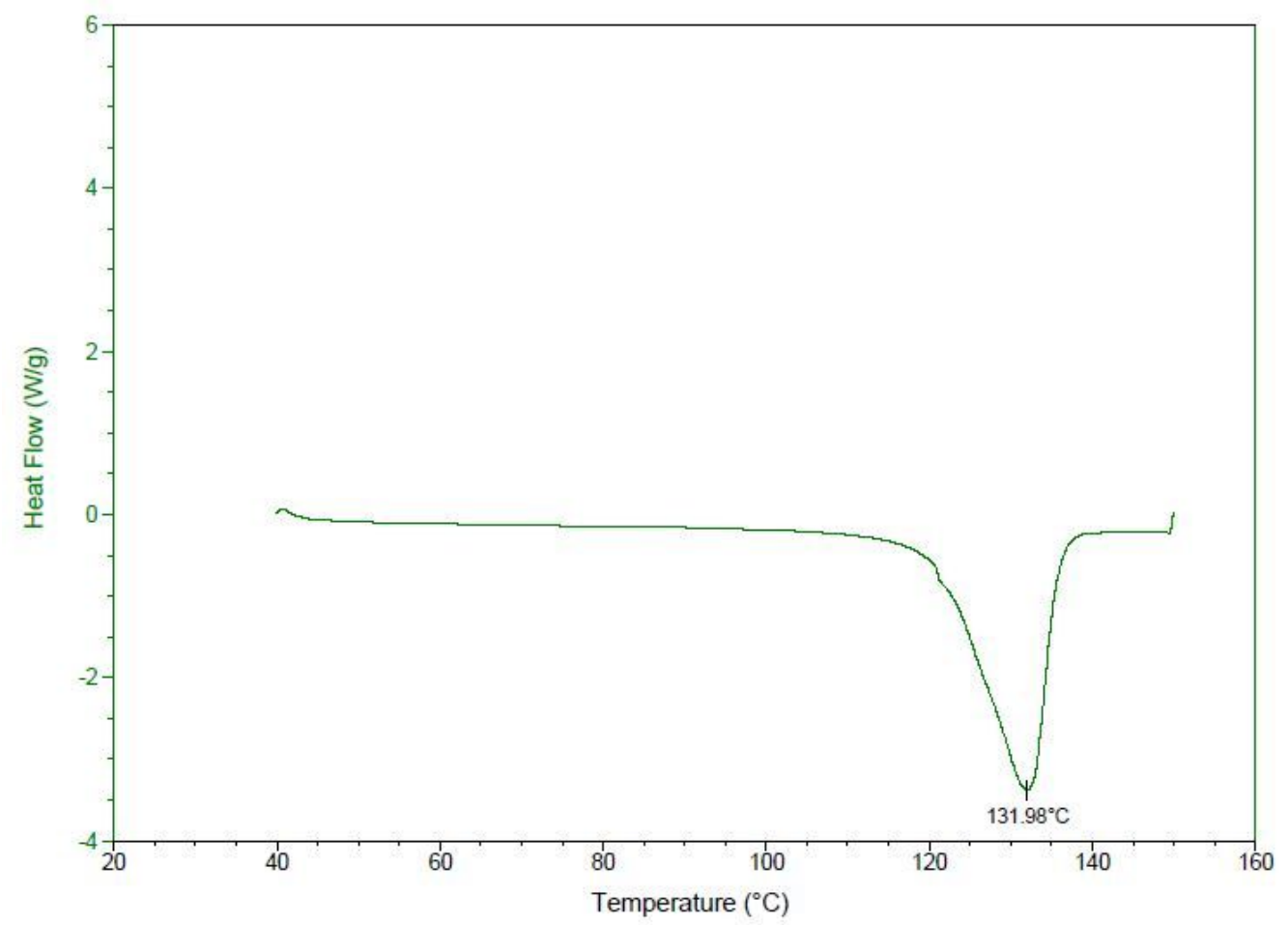

Figure S115. DSC of the polymer from table 1, entry 8. 


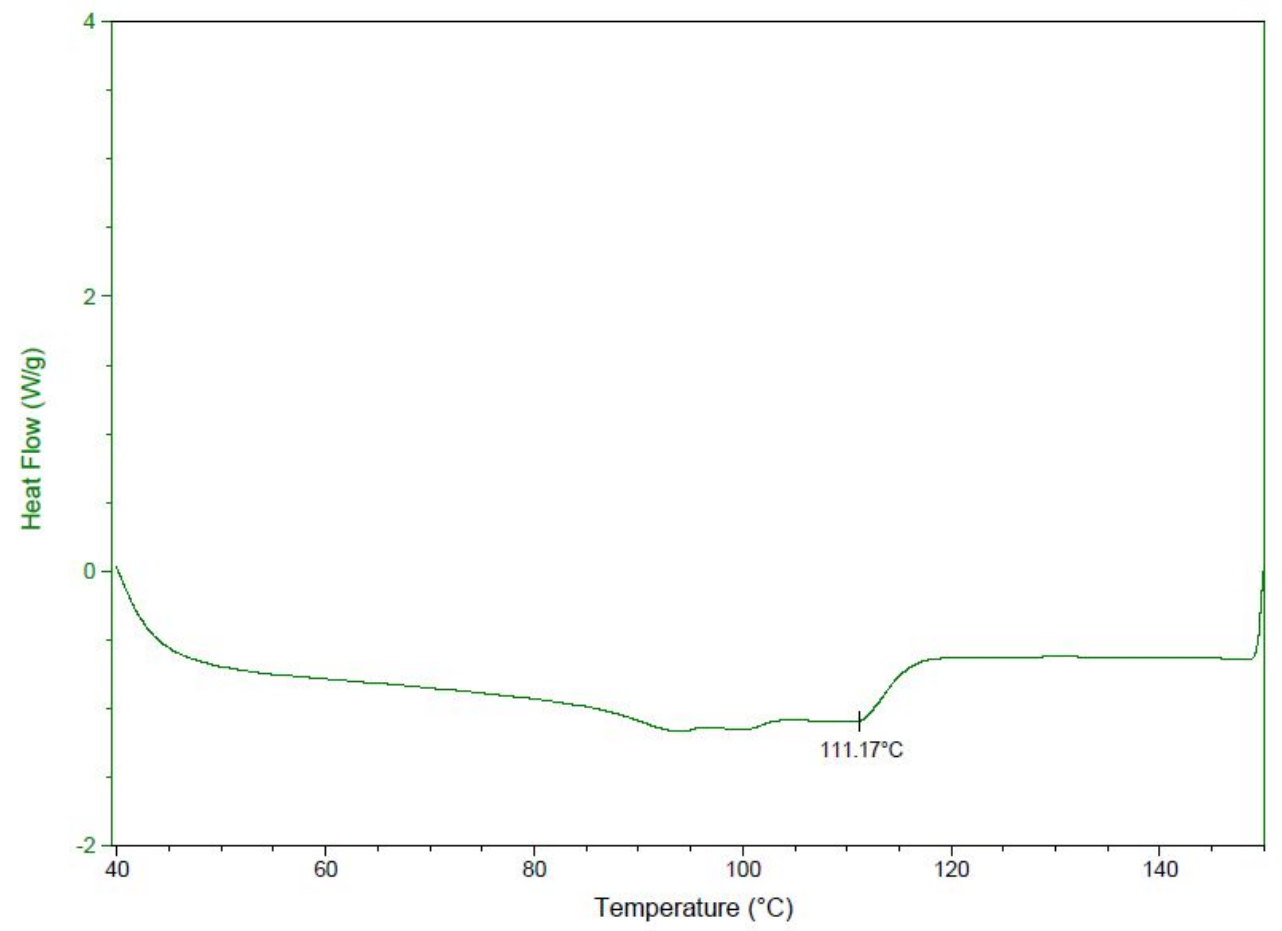

Figure S116. DSC of the polymer from table 1, entry 9.

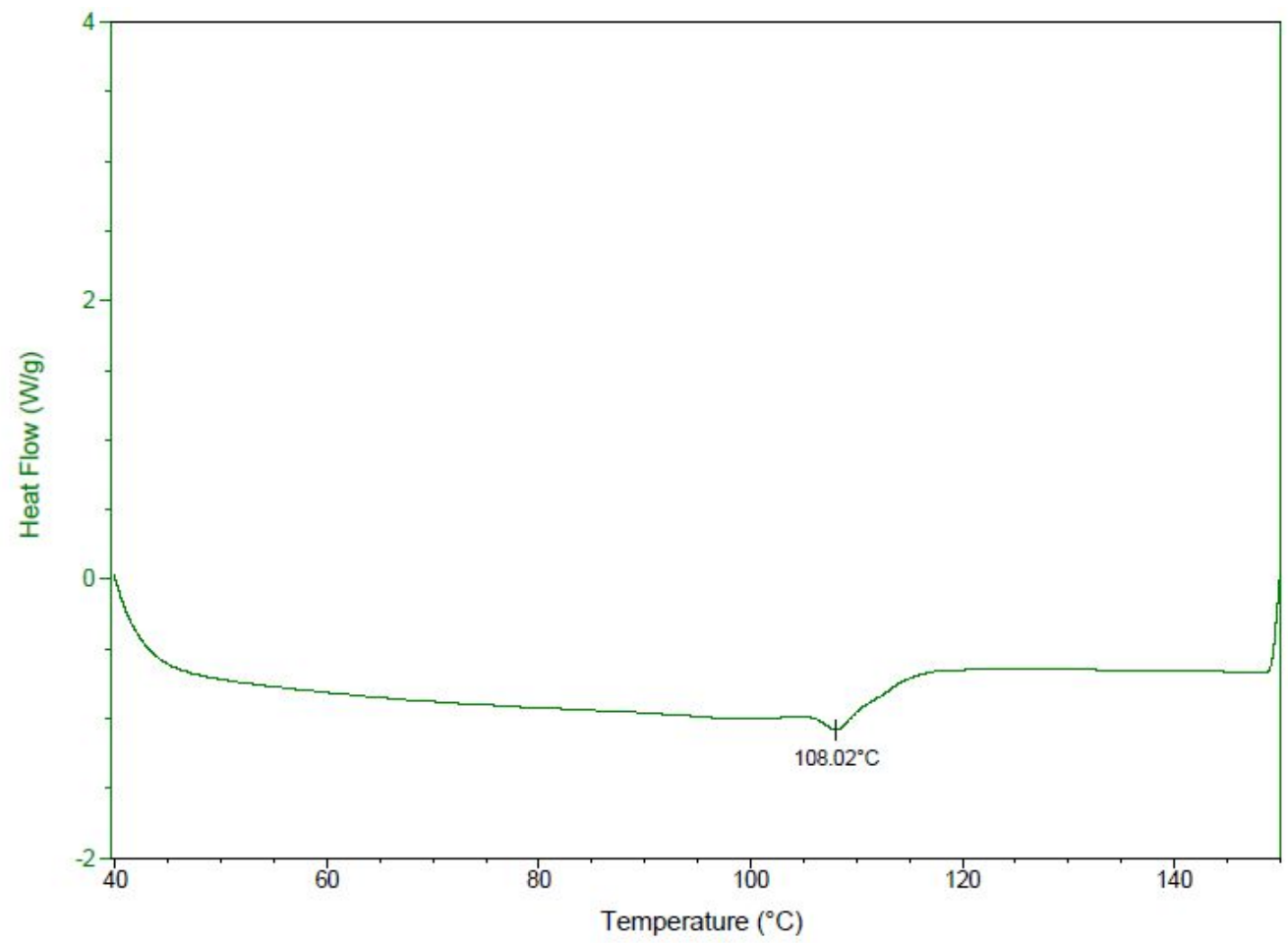

Figure S117. DSC of the polymer from table 1, entry 10. 


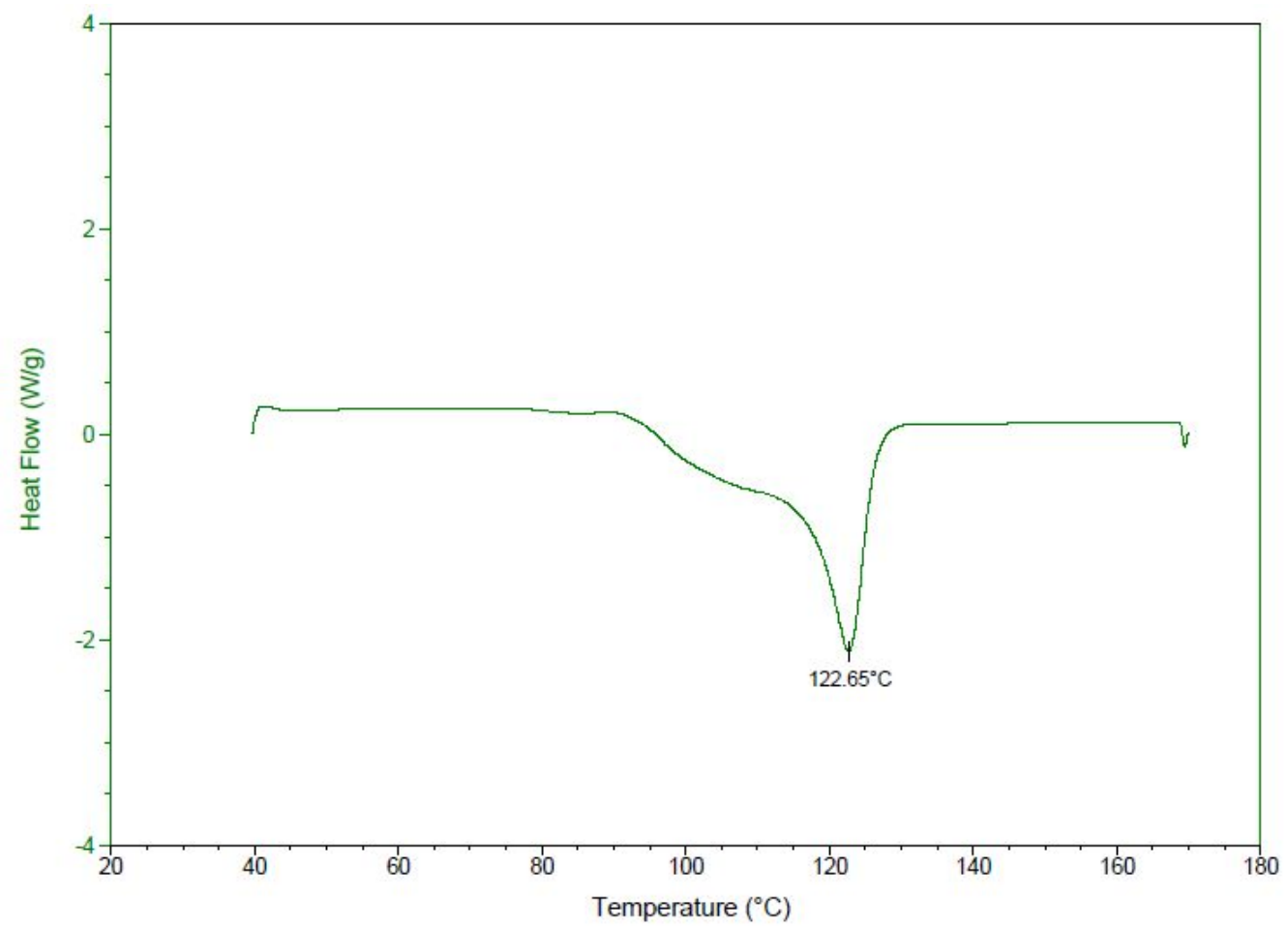

Figure S118. DSC of the polymer from table 1, entry 11.

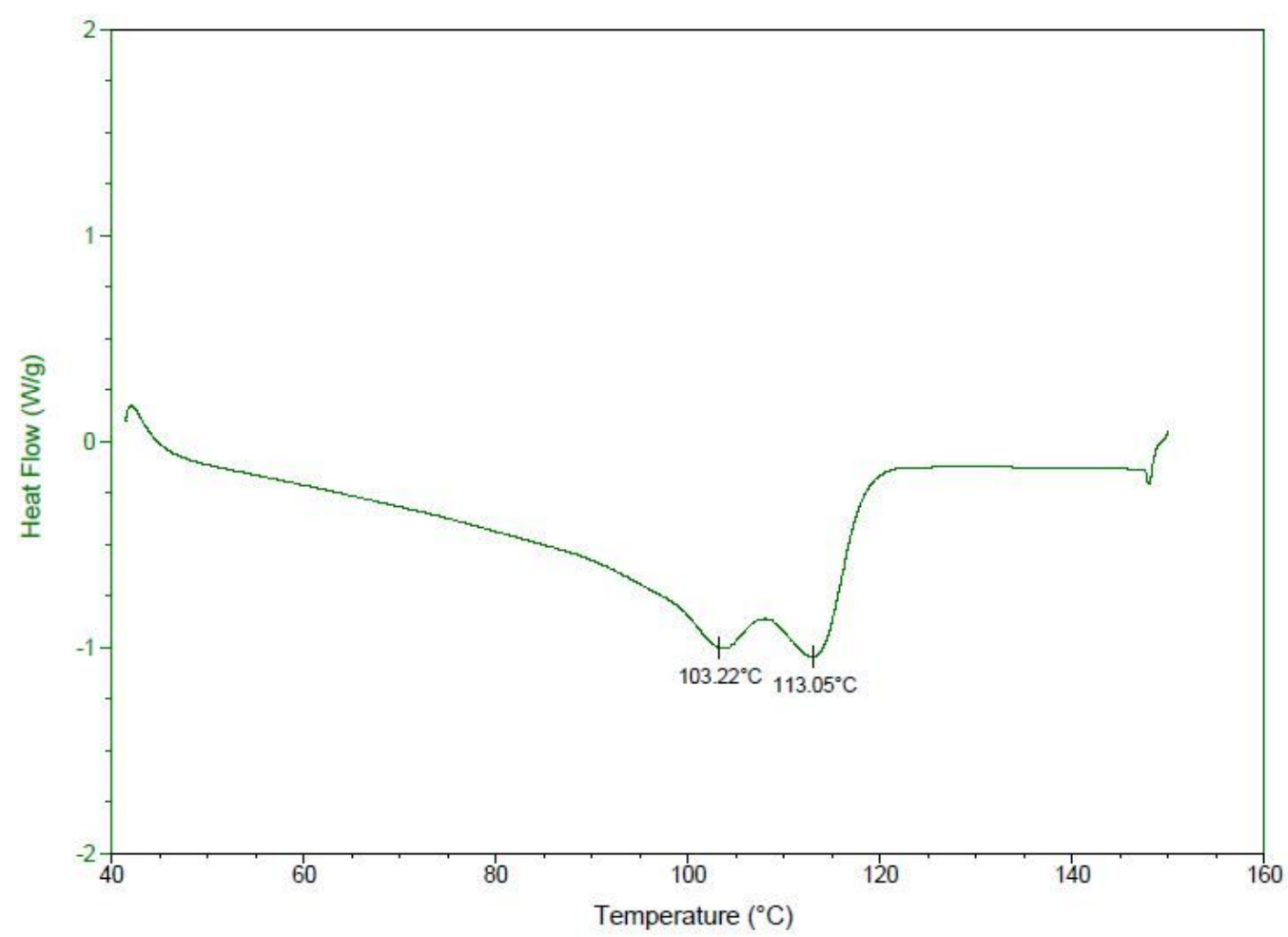

Figure S119. DSC of the polymer from table 1, entry 13. 


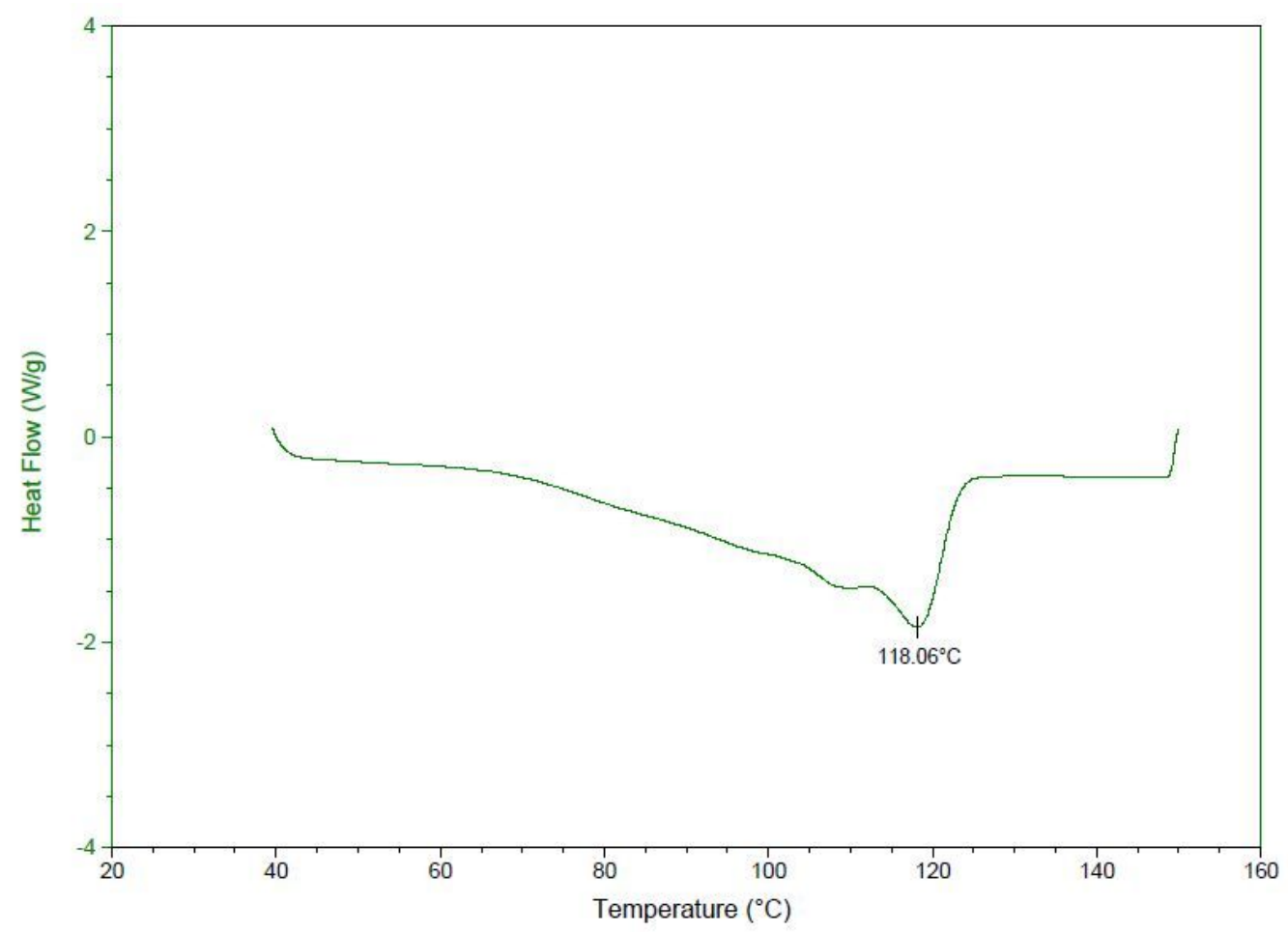

Figure S120. DSC of the polymer from table 1, entry 15.

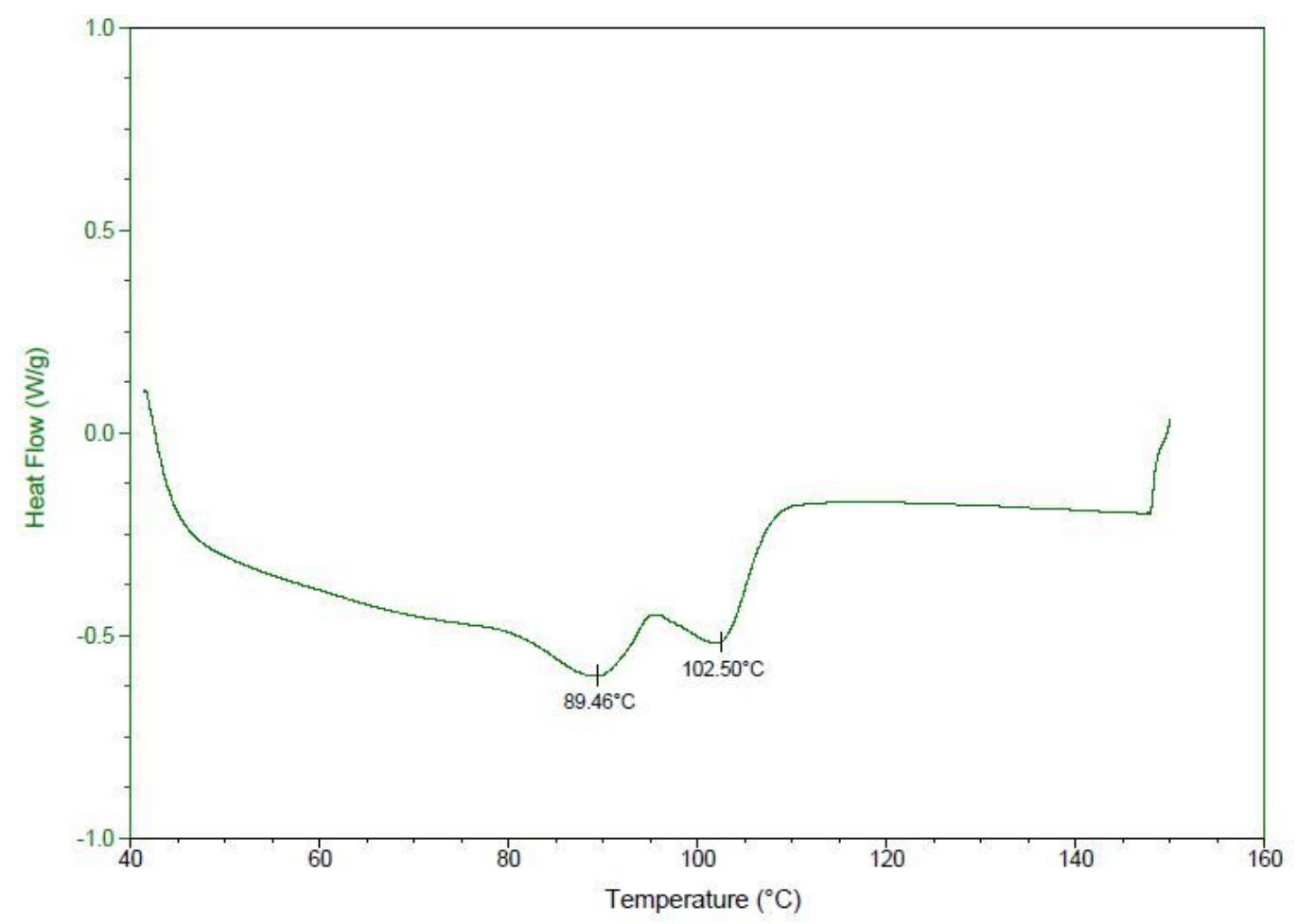

Figure S121. DSC of the polymer from table 1, entry 17. 


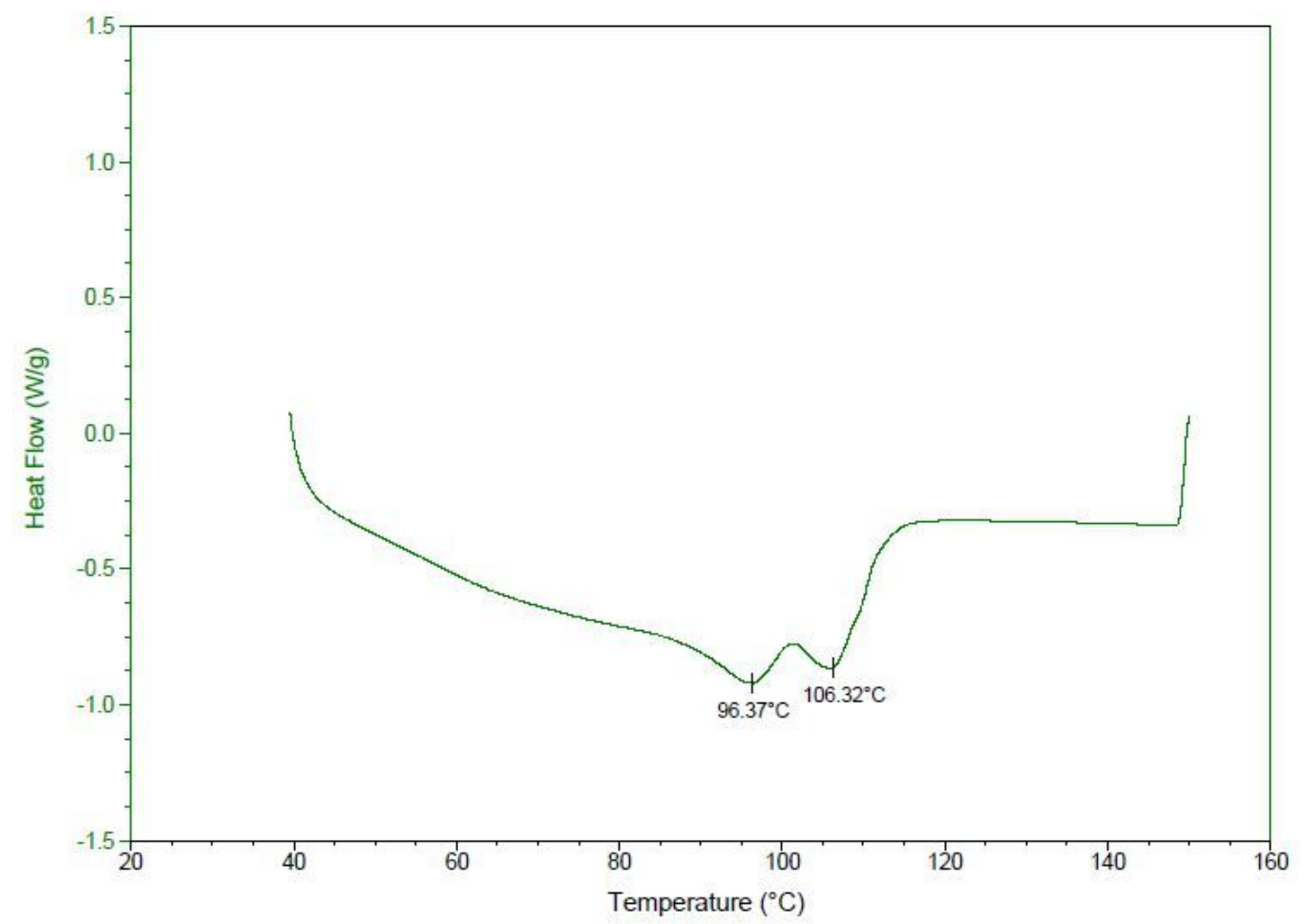

Figure S122. DSC of the polymer from table 1, entry 18.

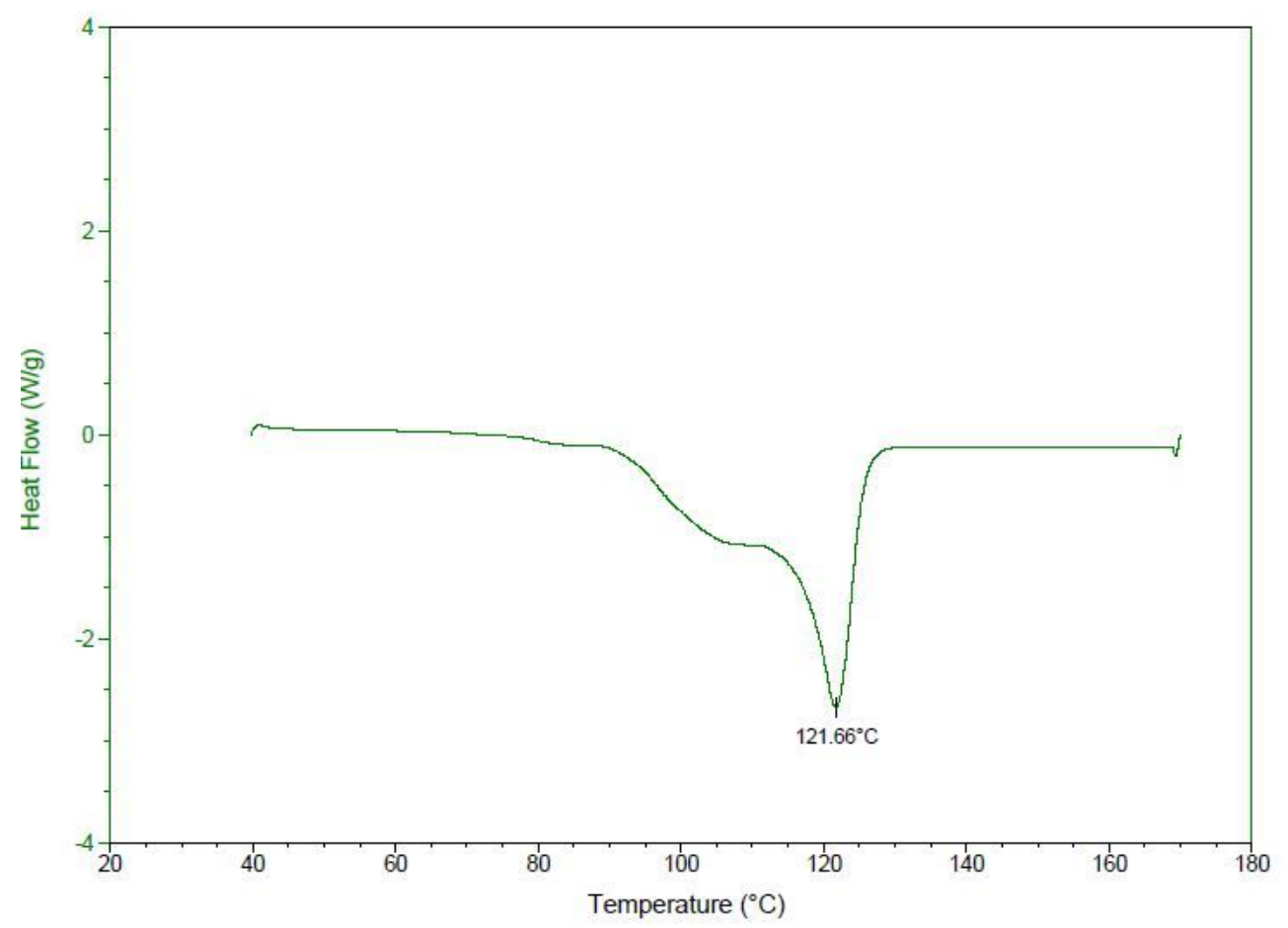

Figure S123. DSC of the polymer from table 1, entry 19. 


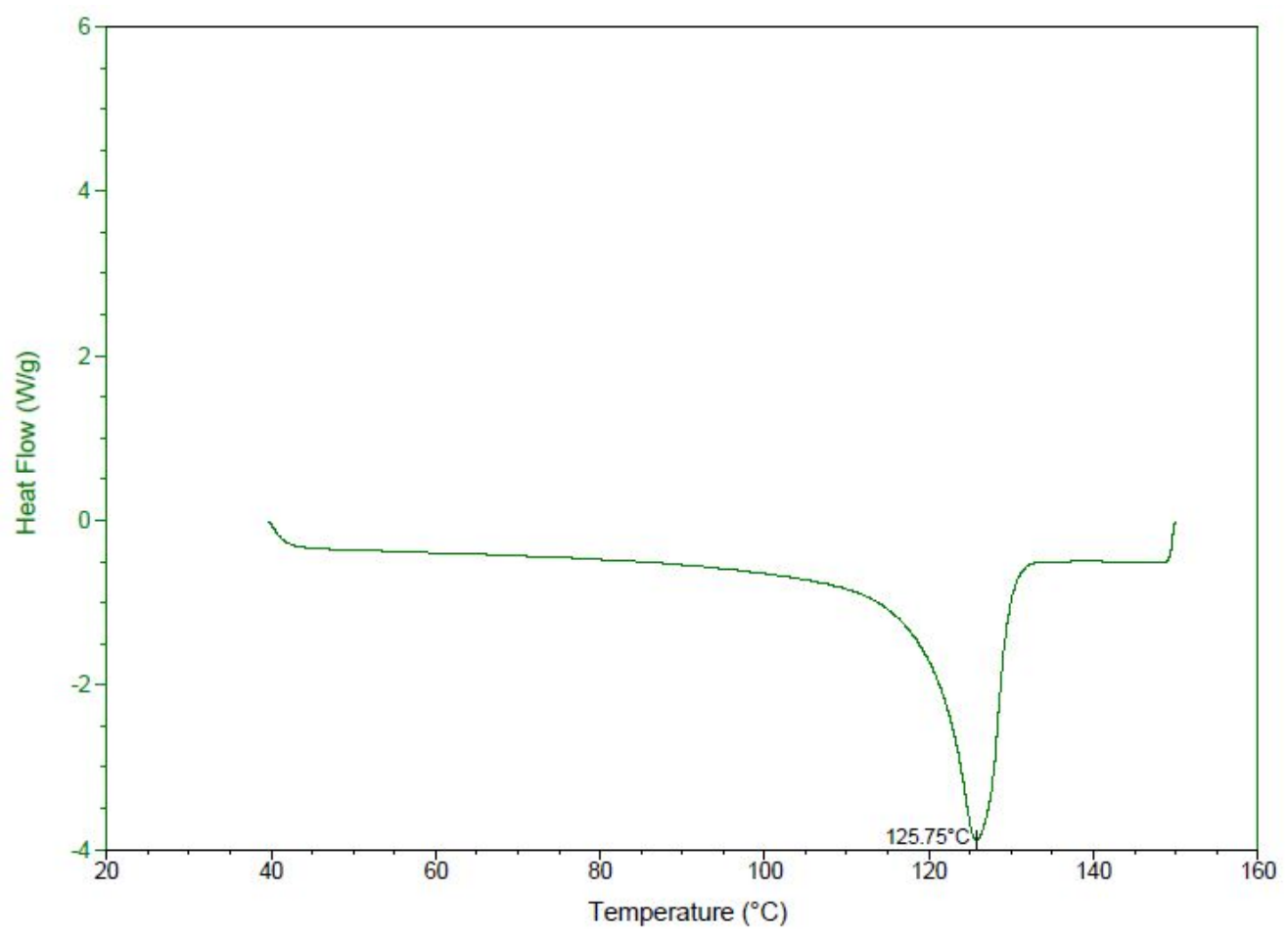

Figure S124. DSC of the polymer from table 1, entry 20.

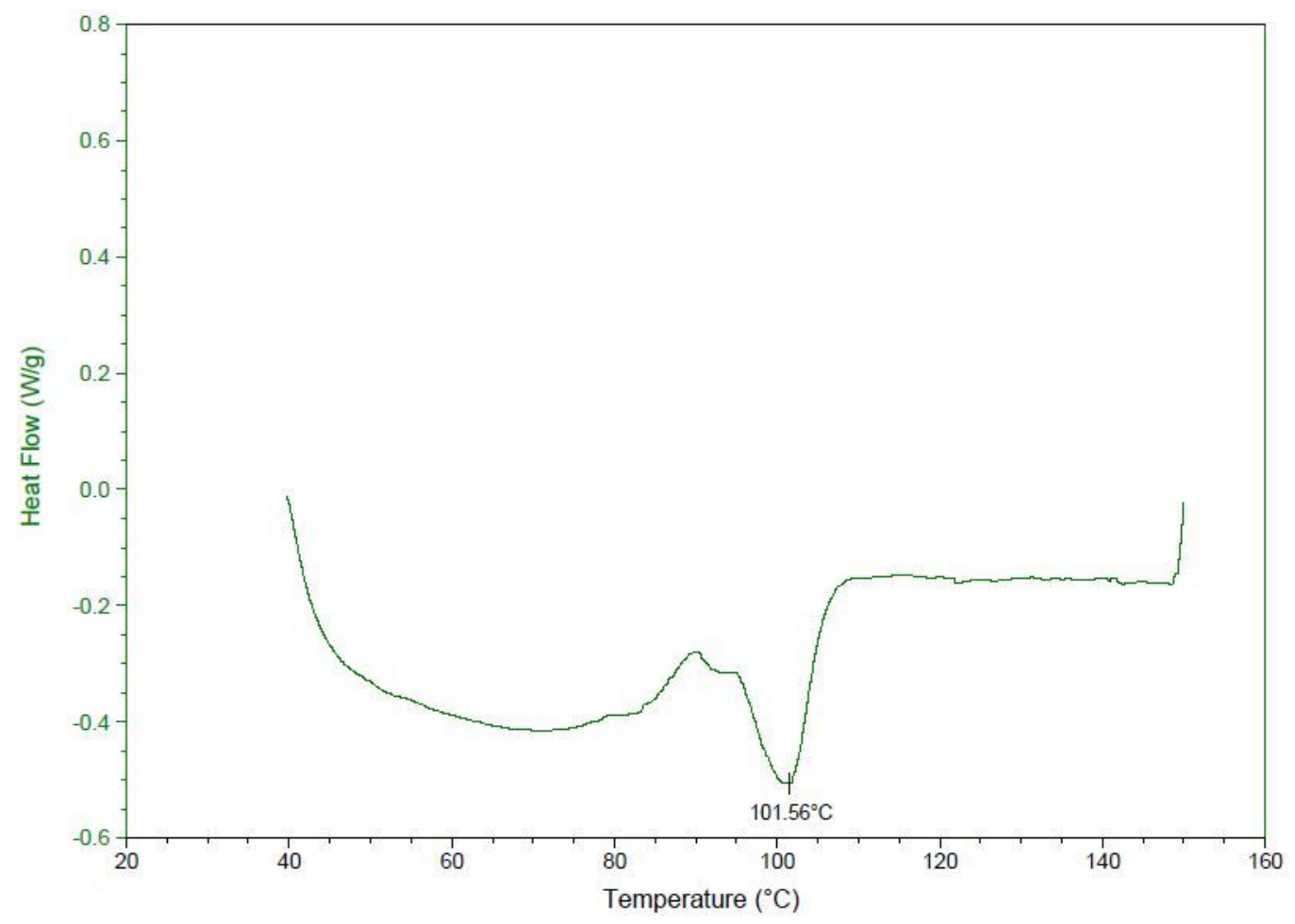

Figure S125. DSC of the polymer from table 1, entry 21. 


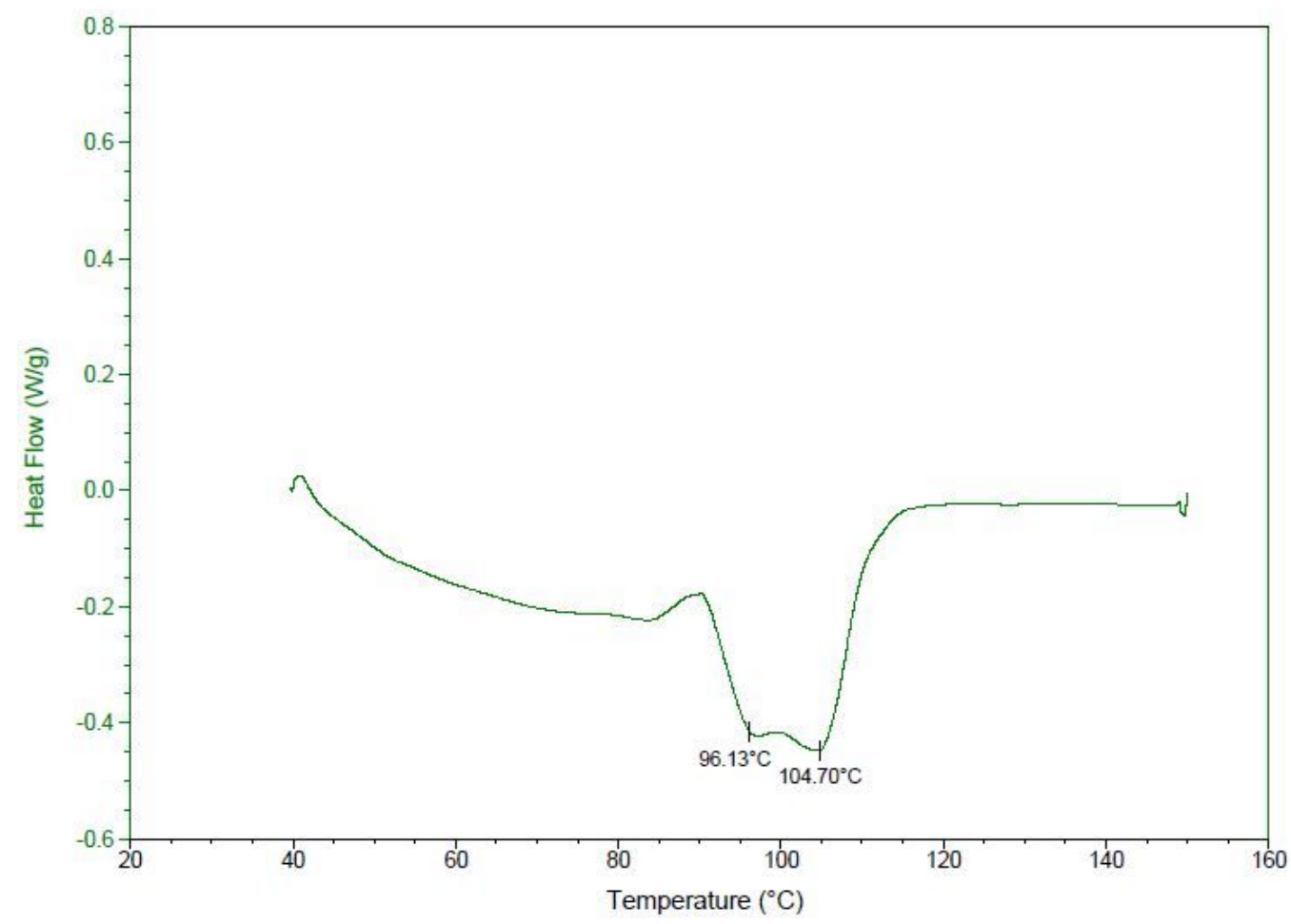

Figure S126. DSC of the polymer from table 1, entry 22.

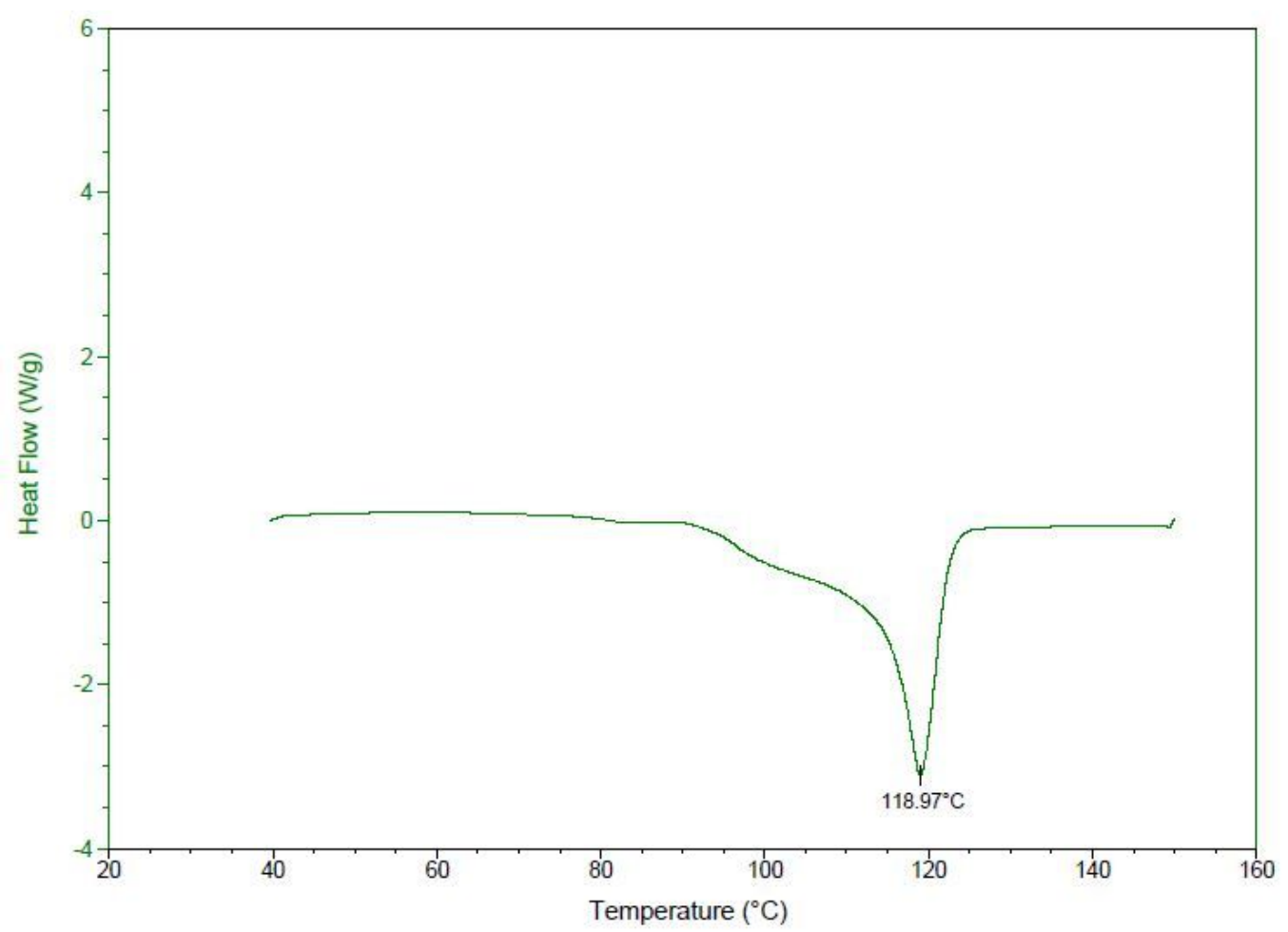

Figure S127. DSC of the polymer from table 2, entry 1. 


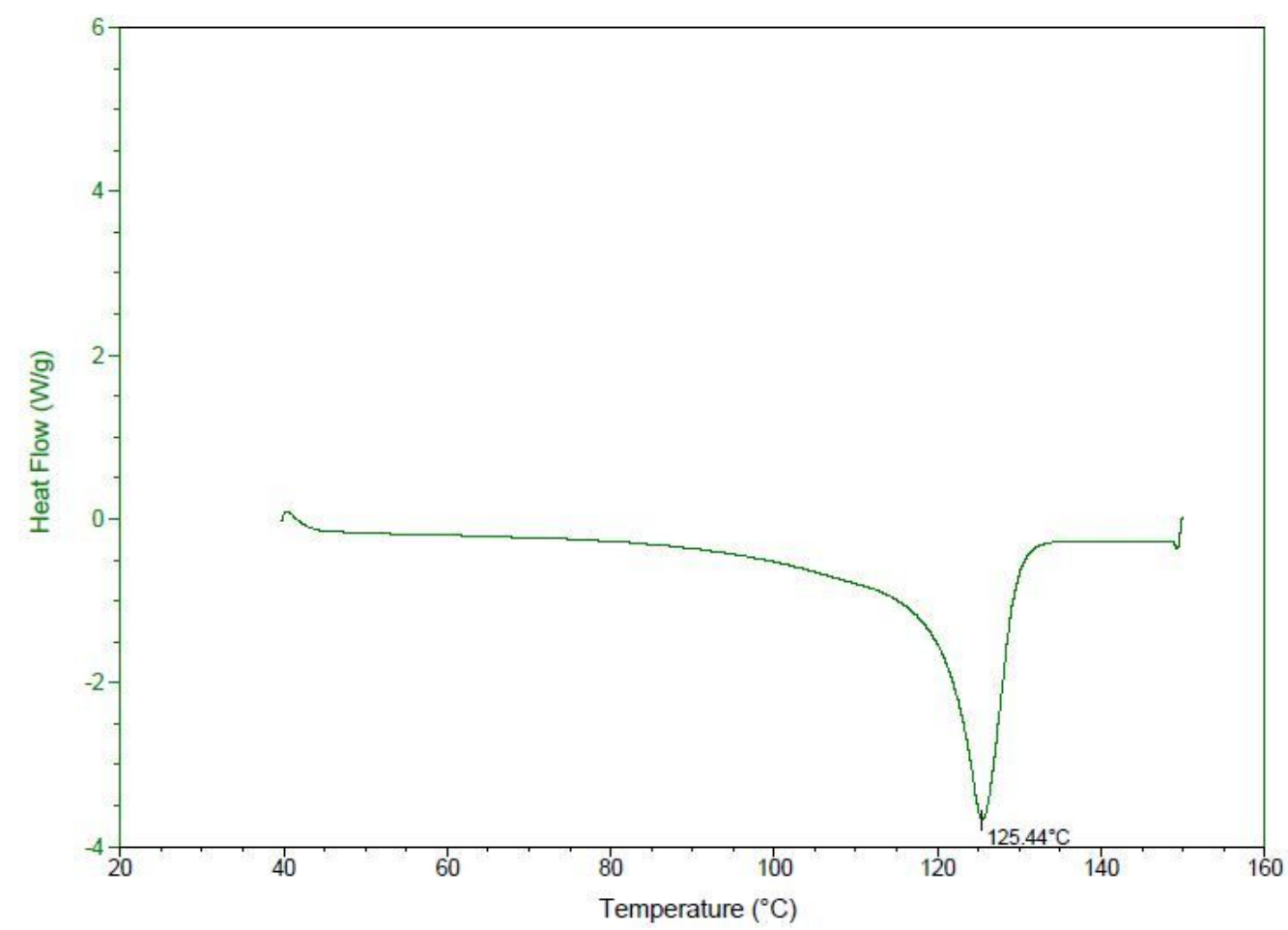

Figure S128. DSC of the polymer from table 2, entry 2.

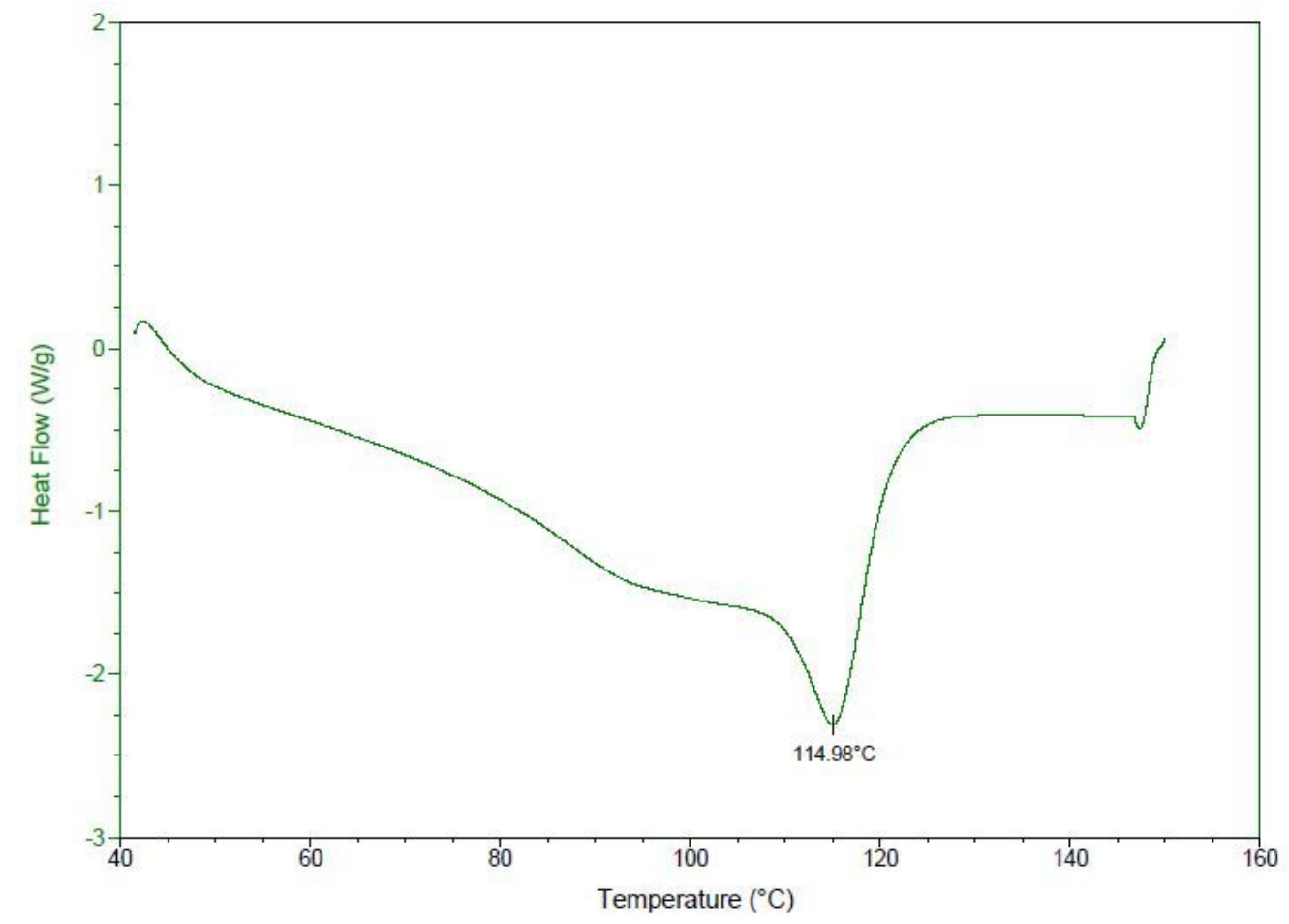

Figure S129. DSC of the polymer from table 2, entry 3. 


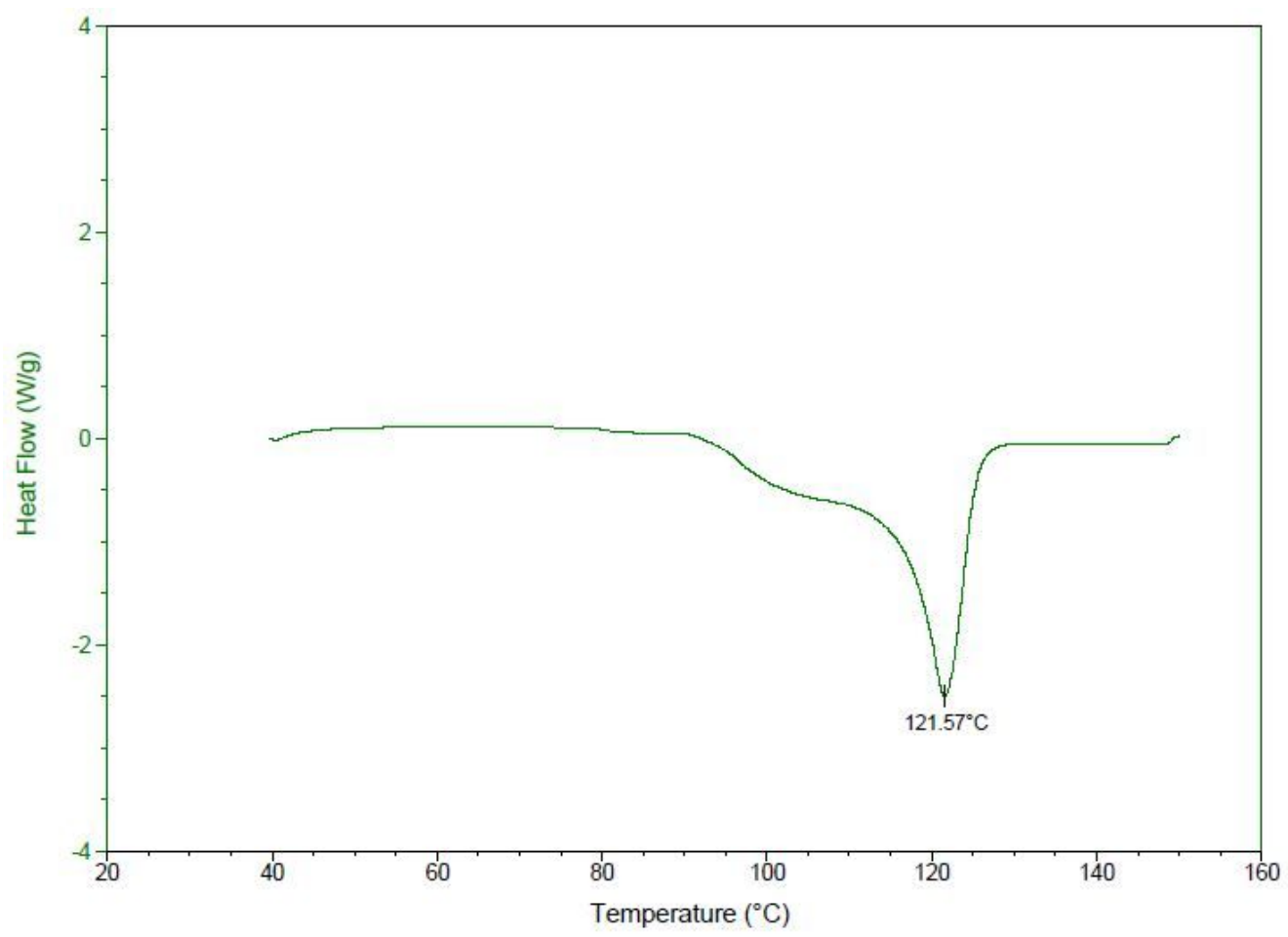

Figure S130. DSC of the polymer from table 2, entry 4.

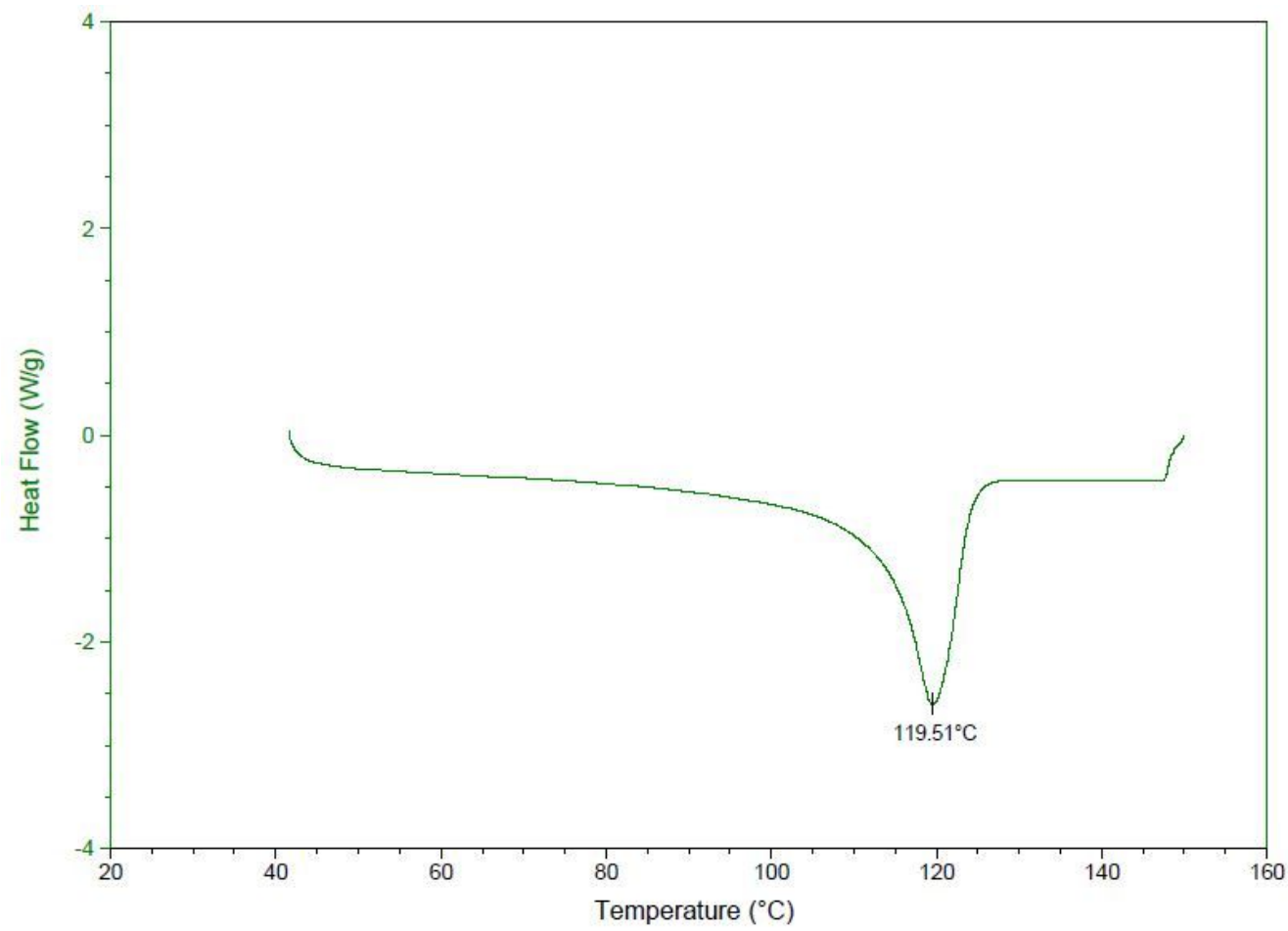

Figure S131. DSC of the polymer from table 2, entry 5. 


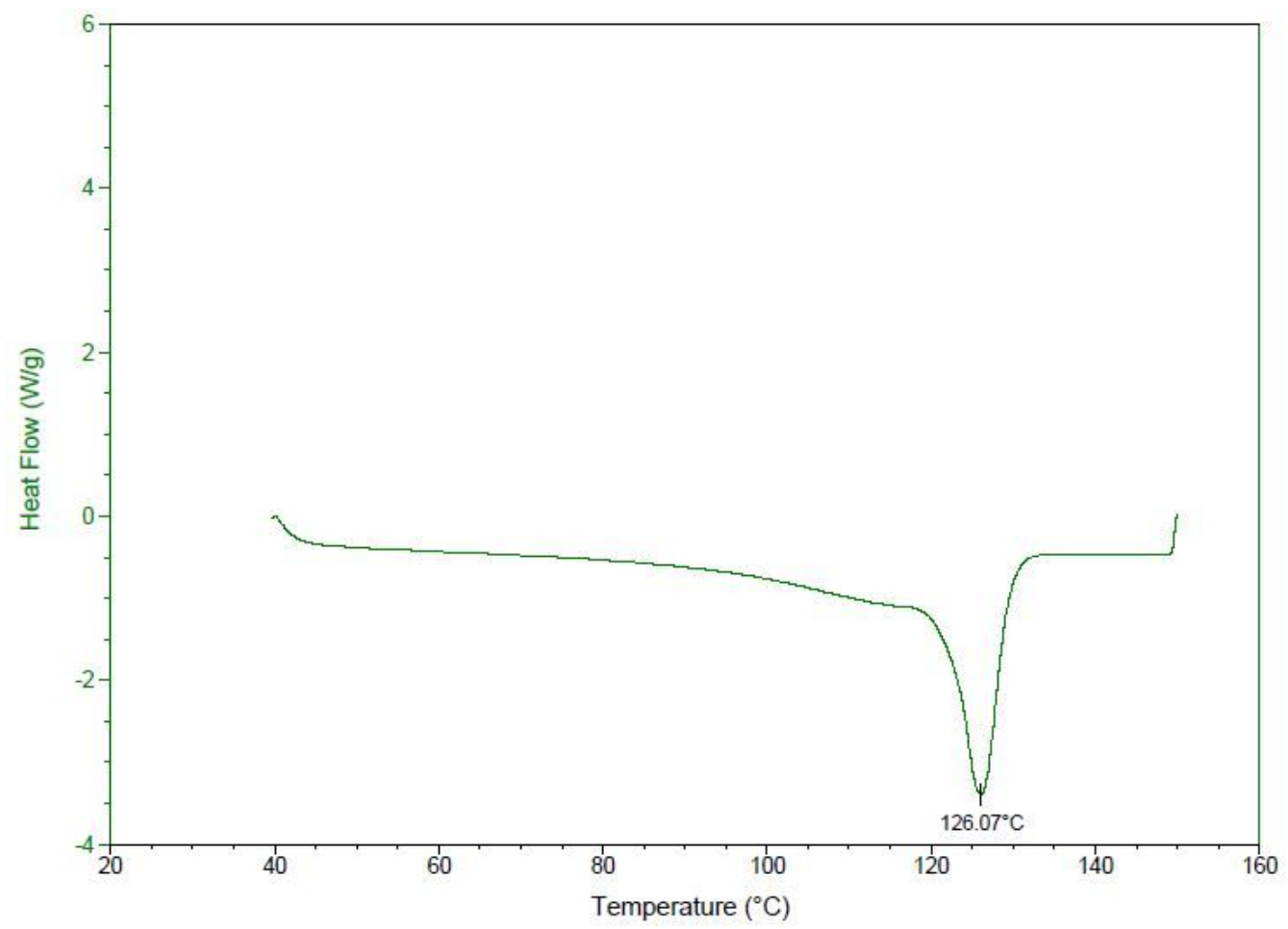

Figure S132. DSC of the polymer from table 2, entry 6.

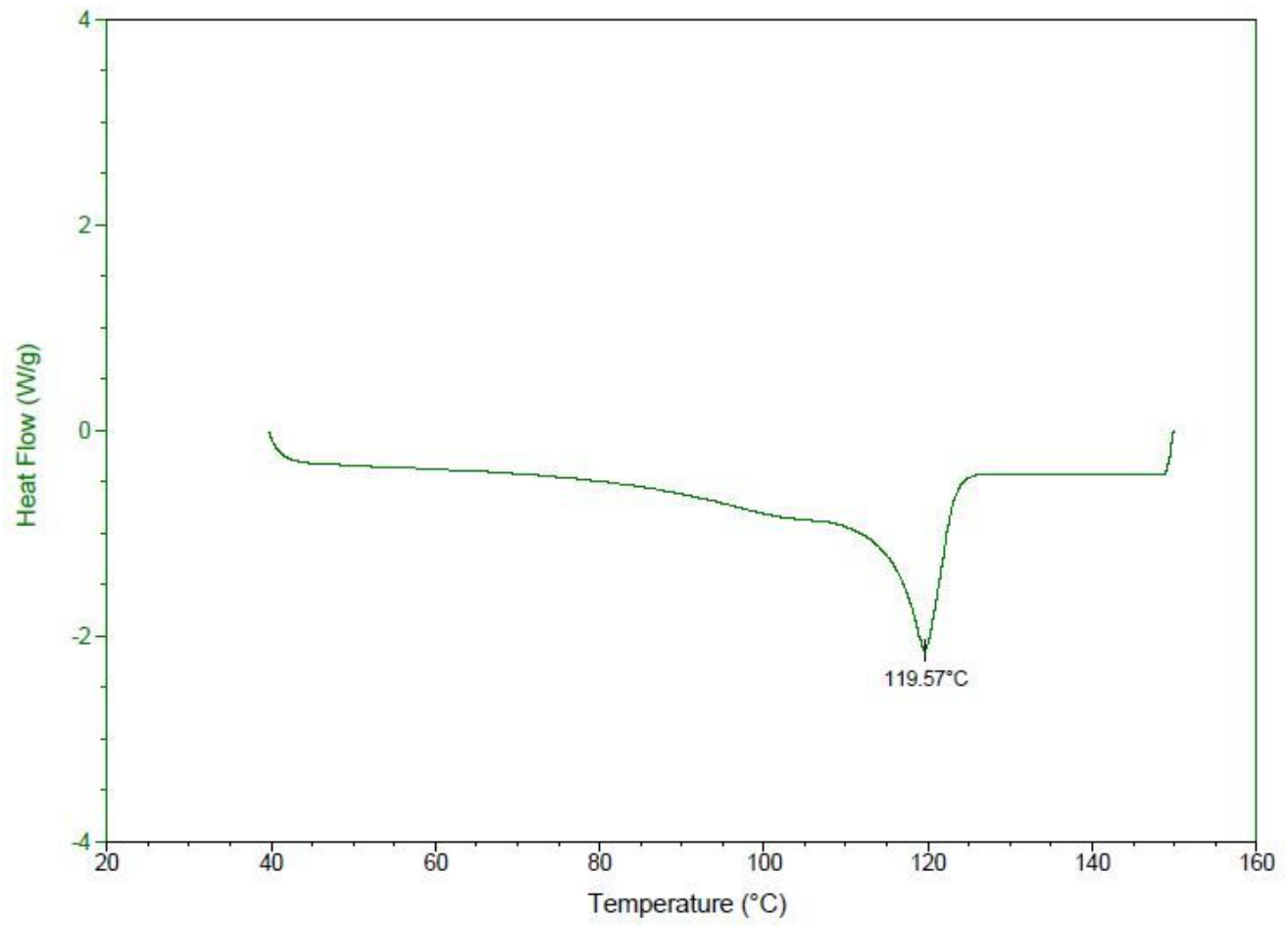

Figure S133. DSC of the polymer from table 2, entry 7. 


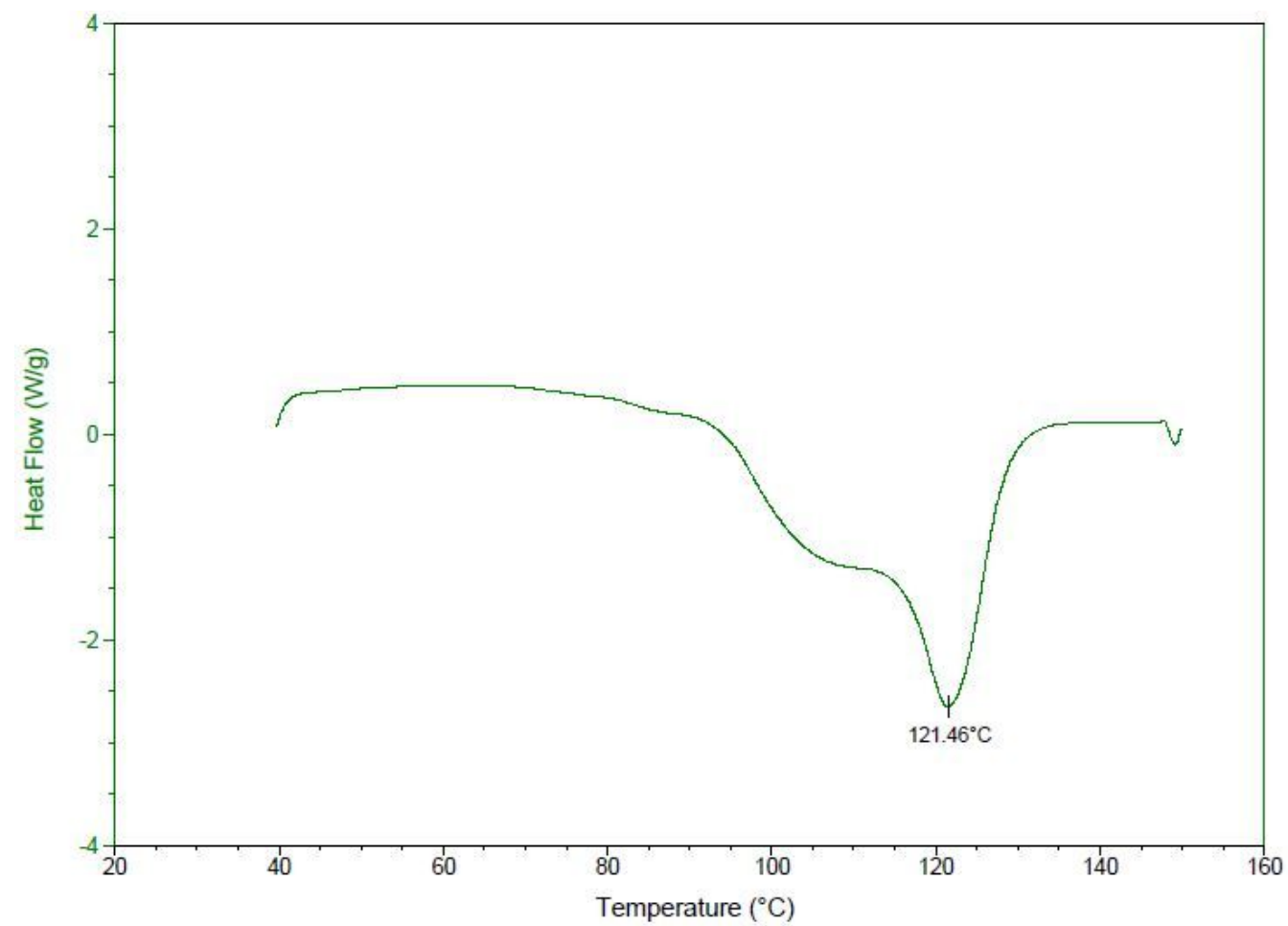

Figure S134. DSC of the polymer from table 2, entry 8.

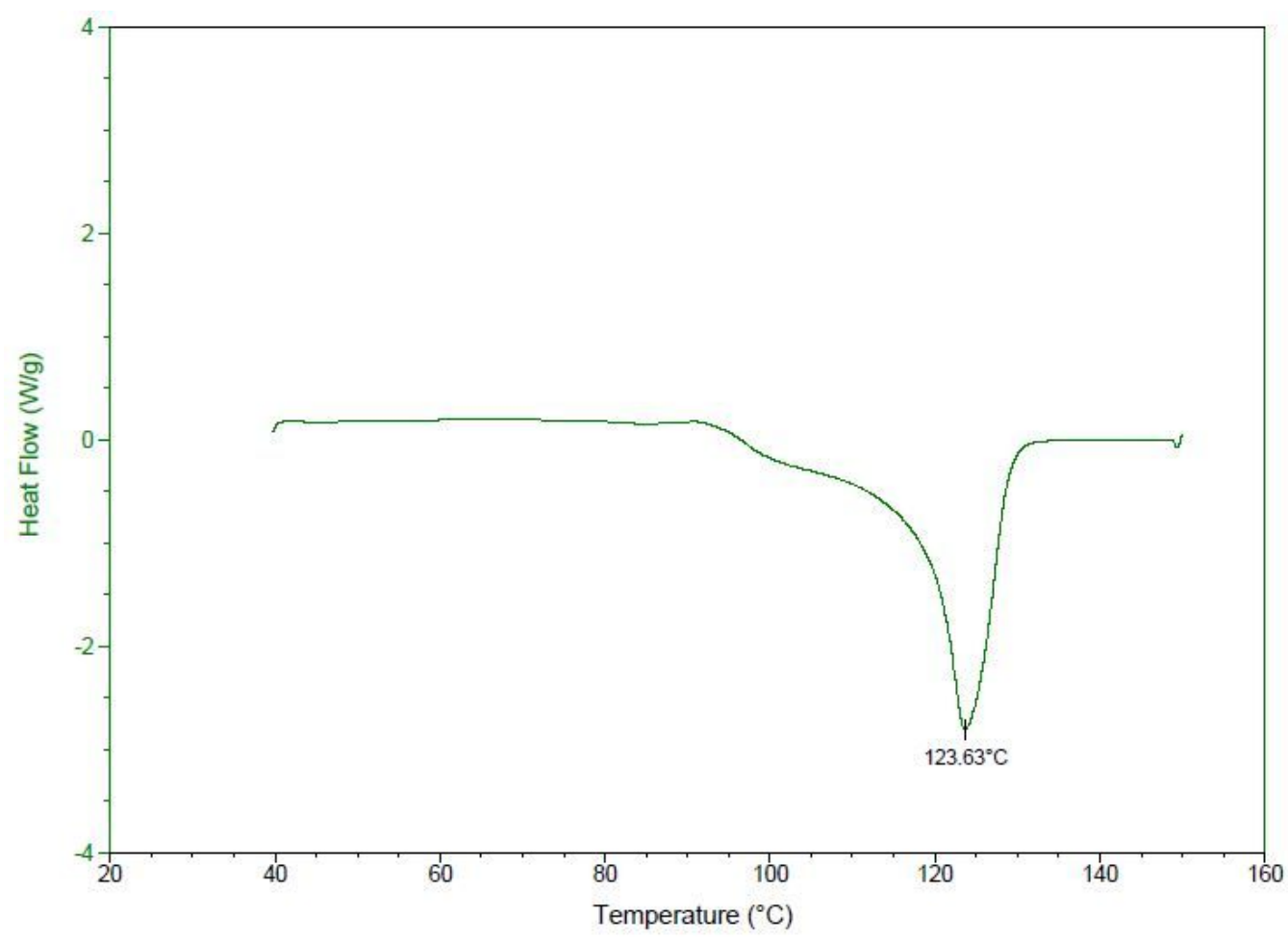

Figure S135. DSC of the polymer from table 2, entry 9. 


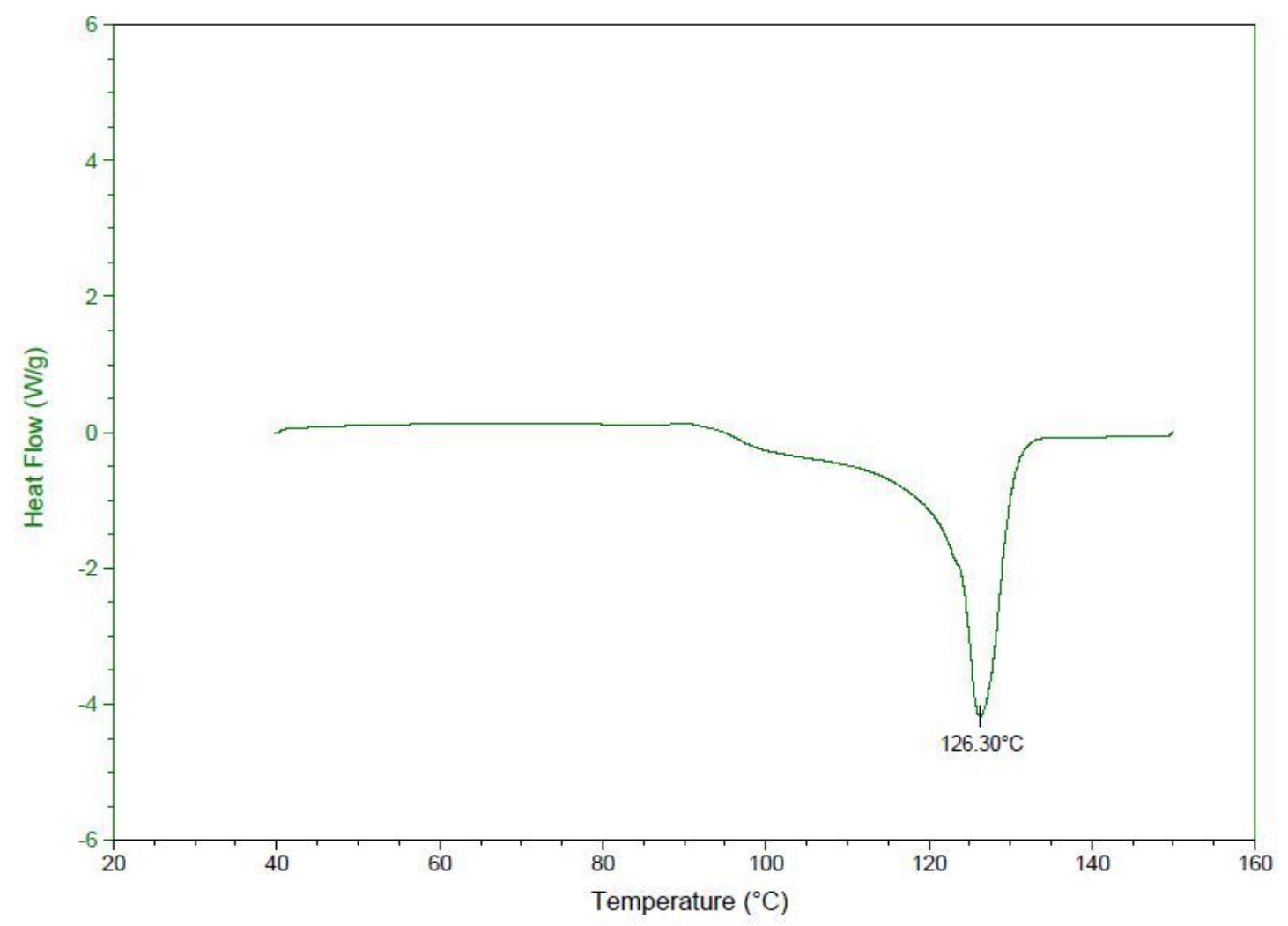

Figure S136. DSC of the polymer from table 2, entry 10.

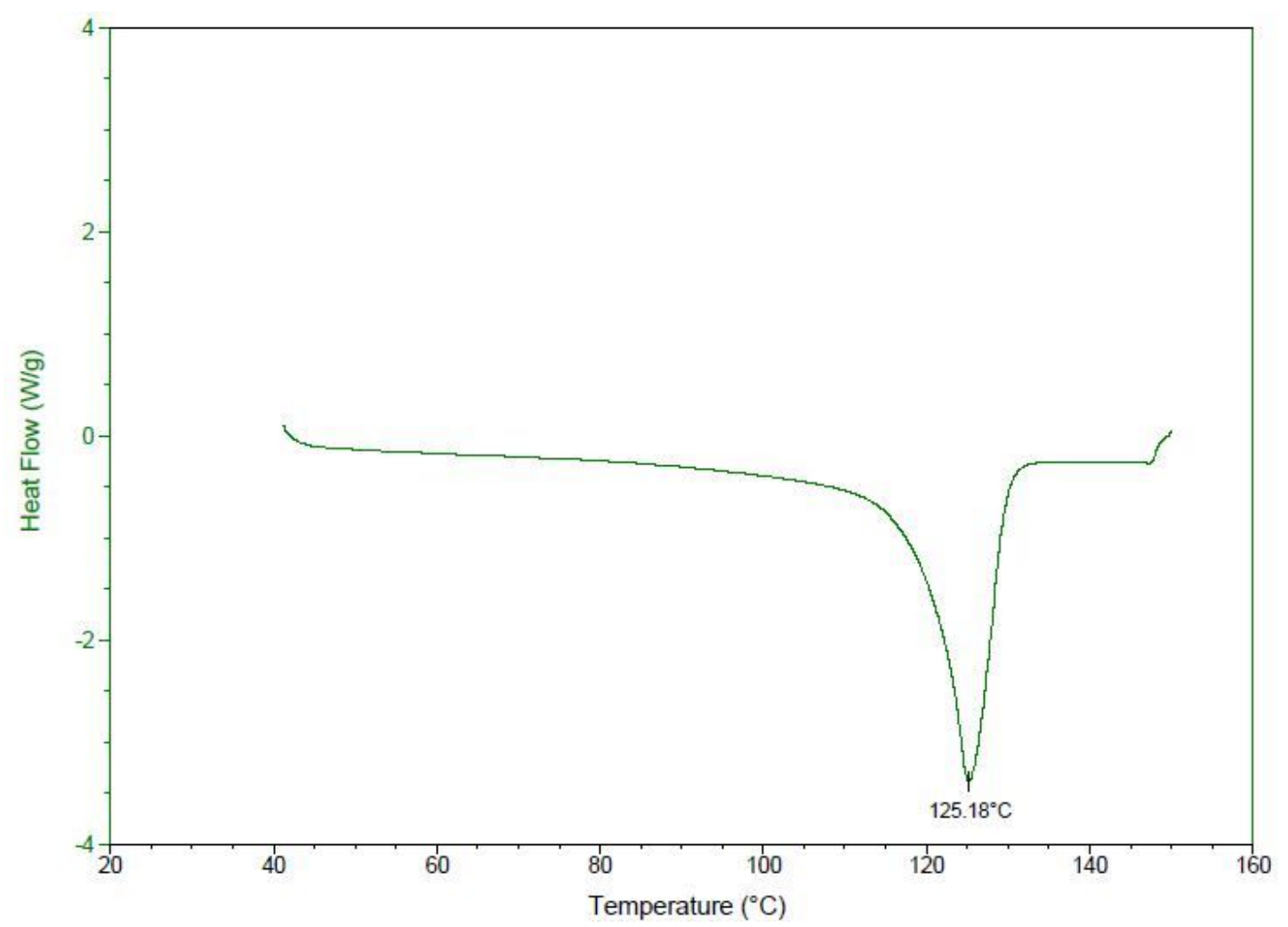

Figure S137. DSC of the polymer from table 2, entry 11. 


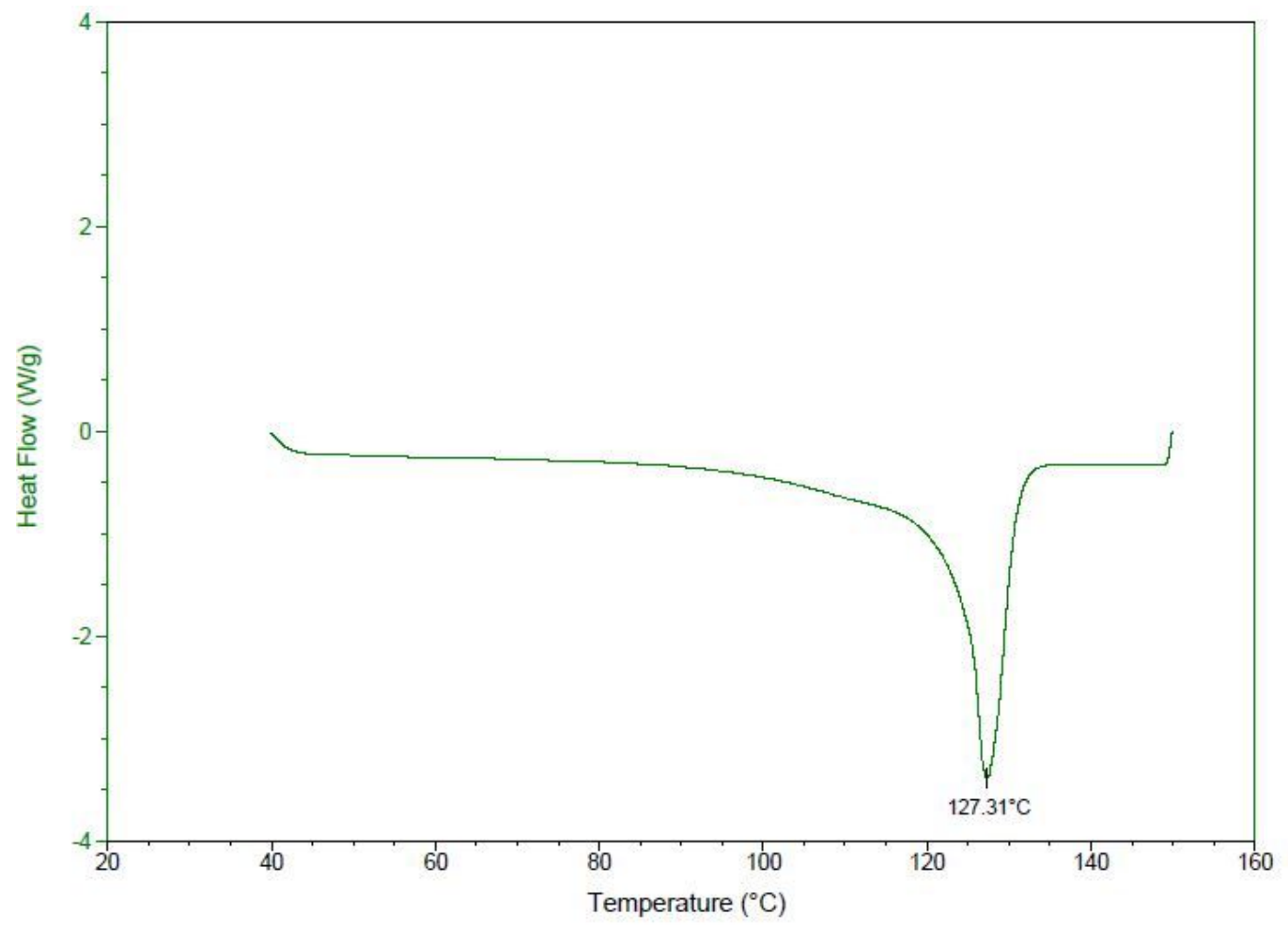

Figure S138. DSC of the polymer from table 2, entry 12.

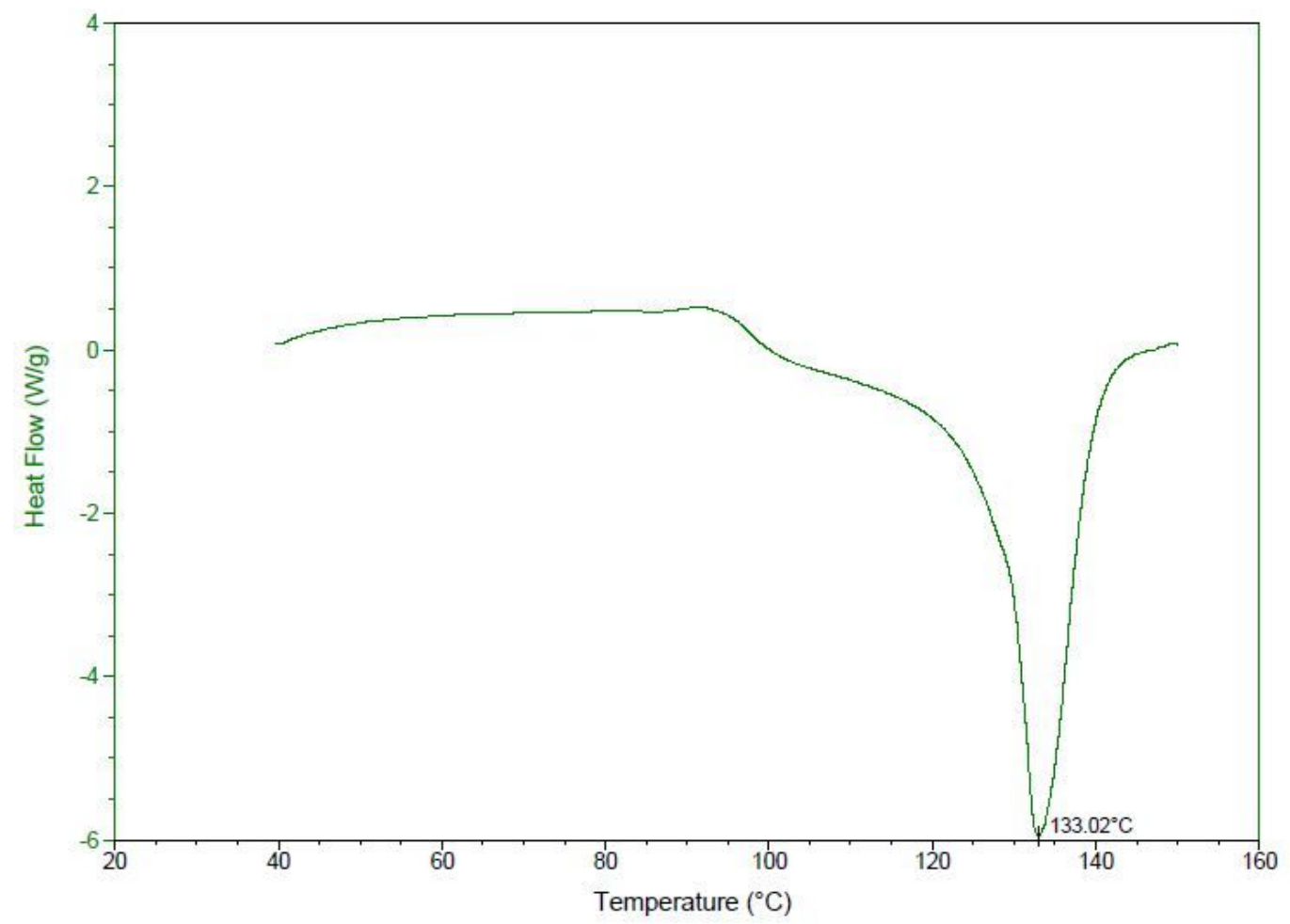

Figure S139. DSC of the polymer from table 2, entry 13. 


\section{GPC of polymers.}

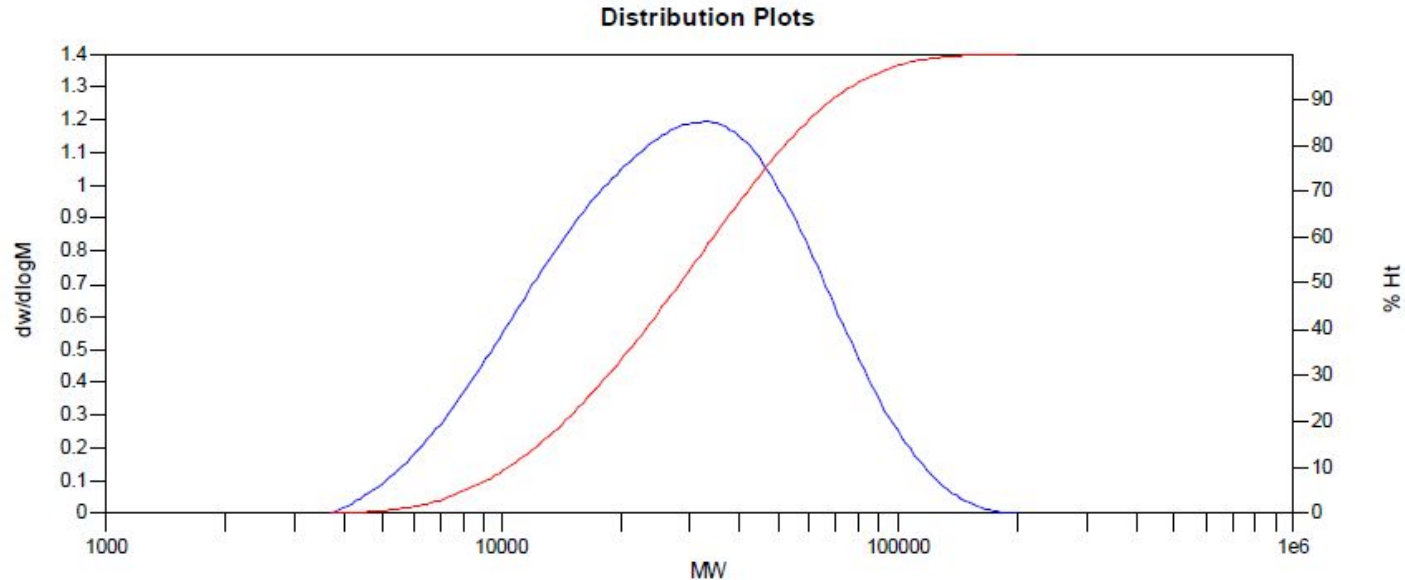

MW Averages

$\begin{array}{llllllll}\text { Peak No } & M p & M n & M w & M z & M z+1 & M v & \text { PD }\end{array}$

$\begin{array}{llllllll}1 & 33274 & 20921 & 34281 & 51636 & 69649 & 31926 & 1.63859\end{array}$

Processed Peaks

\begin{tabular}{|c|c|c|c|c|c|c|c|}
\hline Peak No & Name & $\begin{array}{l}\text { Start RT } \\
\text { (mins) }\end{array}$ & $\begin{array}{c}\text { Max RT } \\
\text { (mins) }\end{array}$ & $\begin{array}{l}\text { End RT } \\
\text { (mins) }\end{array}$ & $\begin{array}{l}\text { Pk Height } \\
(\mathrm{mV})\end{array}$ & $\%$ Height & $\begin{array}{c}\text { Area } \\
(\mathrm{mV} \cdot \mathrm{secs})\end{array}$ \\
\hline 1 & & 13.27 & 14.55 & 15.98 & -27.1155 & 100 & 2145.02 \\
\hline
\end{tabular}

Figure S140. GPC data of the polymer from table 1, entry 3

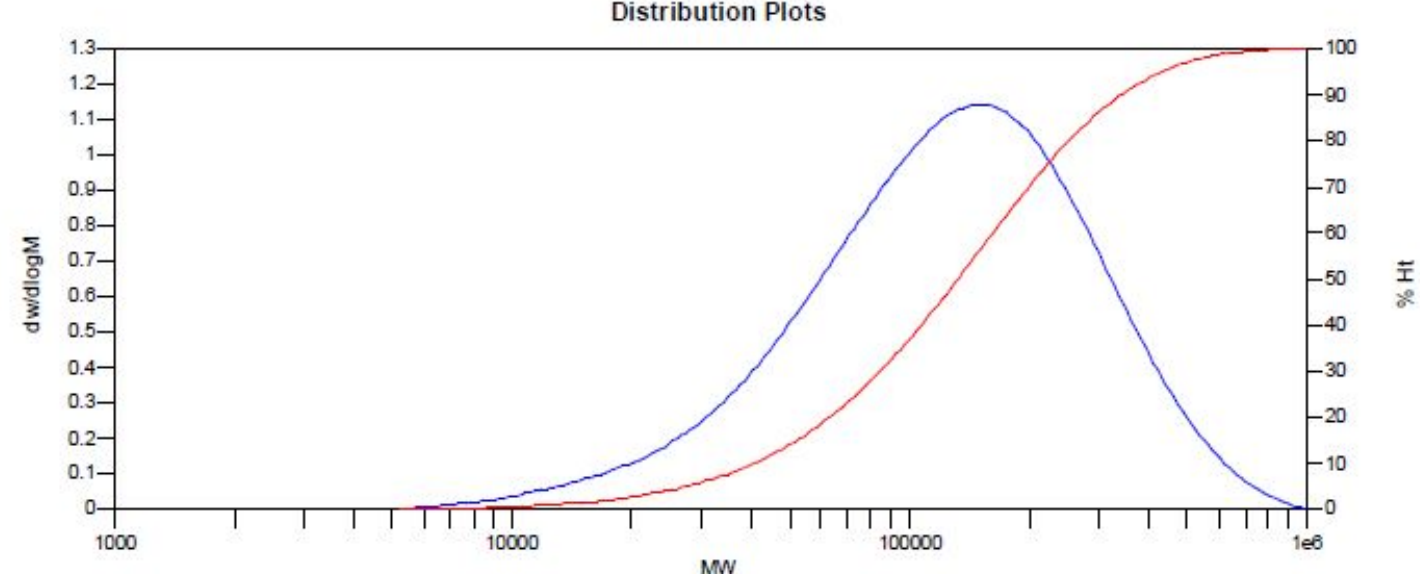

MW Averages

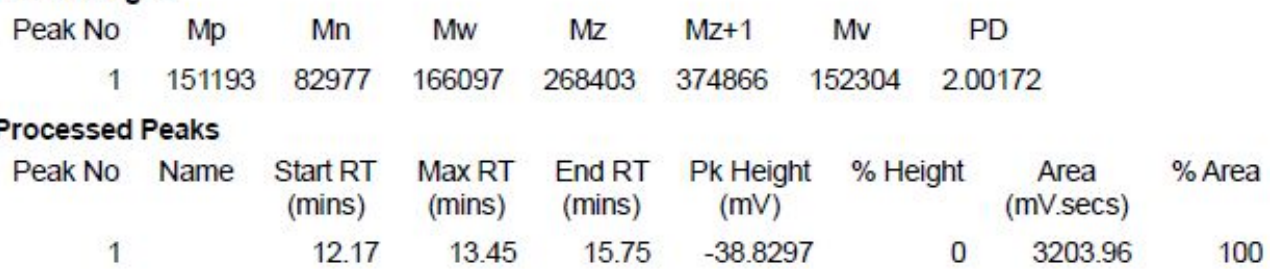

Figure S141. GPC data of the polymer from table 1, entry 4. 


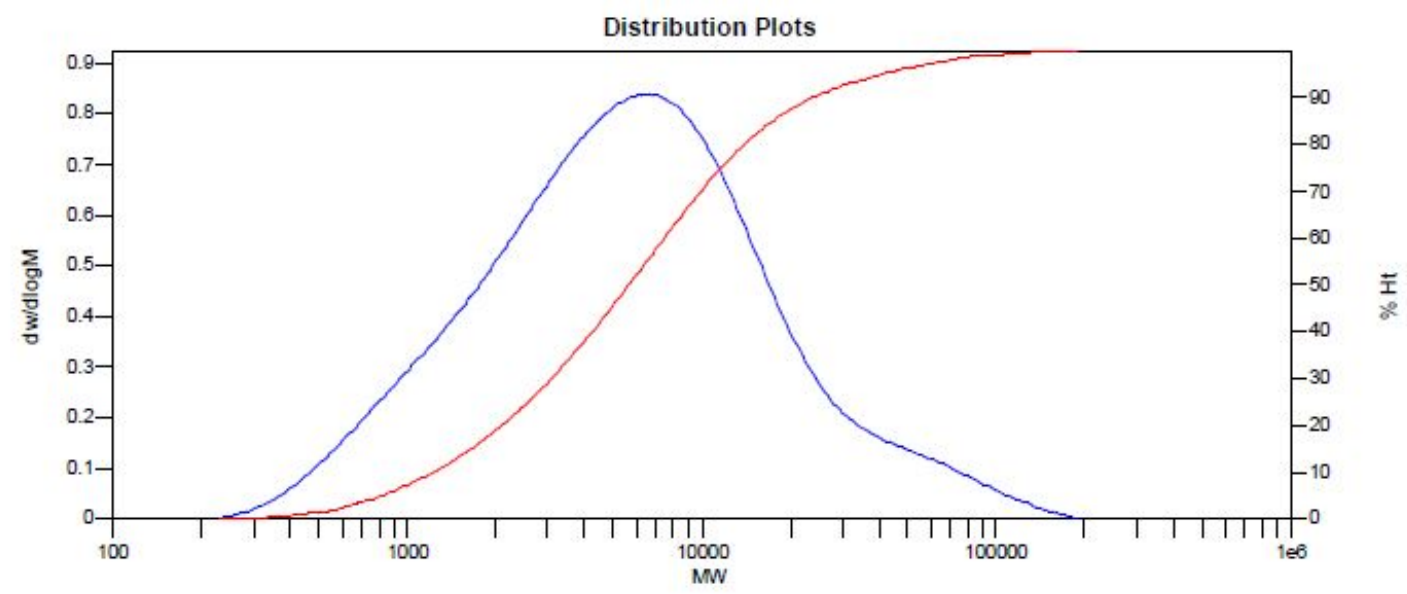

MW Averages

$\begin{array}{rccccccccc}\text { Peak No } & \text { Mp } & \text { Mn } & \text { Mw } & \text { Mz } & \text { Mz+1 } & \text { Mv } & \text { PD } & \\ 1 & 6481 & 2989 & 10757 & 35916 & 72359 & 8746 & 3.59886 & & \\ \text { Processed Peaks } & & & & & & & & \\ \text { Peak No } & \text { Name } & \begin{array}{c}\text { Start RT } \\ \text { (mins) }\end{array} & \begin{array}{c}\text { Max RT } \\ \text { (mins) }\end{array} & \begin{array}{c}\text { End RT } \\ \text { (mins) }\end{array} & \begin{array}{c}\text { Pk Height } \\ \text { (mV) }\end{array} & \% \text { Height } & \begin{array}{c}\text { Area } \\ \text { (mV.secs) }\end{array} & \text { \% Area } \\ 1 & & 13.30 & 15.60 & 17.88 & -30.1246 & 100 & 3382.91 & 100\end{array}$

Figure S142. GPC data of the polymer from table 1, entry 5

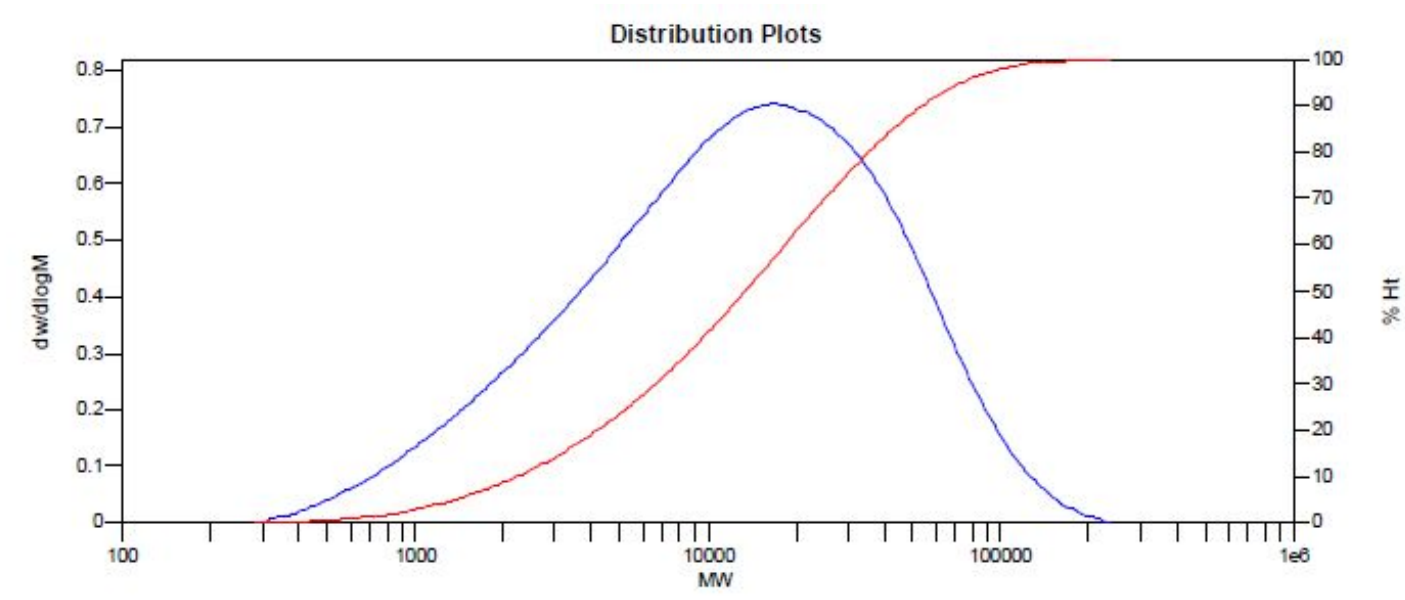

MW Averages

$\begin{array}{rccccccccc}\text { Peak No } & \text { Mp } & \text { Mn } & \text { Mw } & \text { Mz } & \text { Mz+1 } & \text { Mv } & \text { PD } & \\ 1 & 16796 & 5510 & 22028 & 50728 & 80927 & 18662 & 3.99782 & & \\ \text { Processed Peaks } & & & & & & & & \\ \text { Peak No } & \text { Name } & \begin{array}{c}\text { Start RT } \\ \text { (mins) }\end{array} & \begin{array}{c}\text { Max RT } \\ \text { (mins) }\end{array} & \begin{array}{c}\text { End RT } \\ \text { (mins) }\end{array} & \begin{array}{c}\text { Pk Height } \\ \text { (mV) }\end{array} & \% \text { Height } & \begin{array}{c}\text { Area } \\ \text { (mV.secs) }\end{array} & \% \text { Area } \\ 1 & & 13.15 & 14.95 & 17.73 & -29.6734 & 100 & 3780.26 & 100\end{array}$

Figure S143. GPC data of the polymer from table 1, entry 6. 

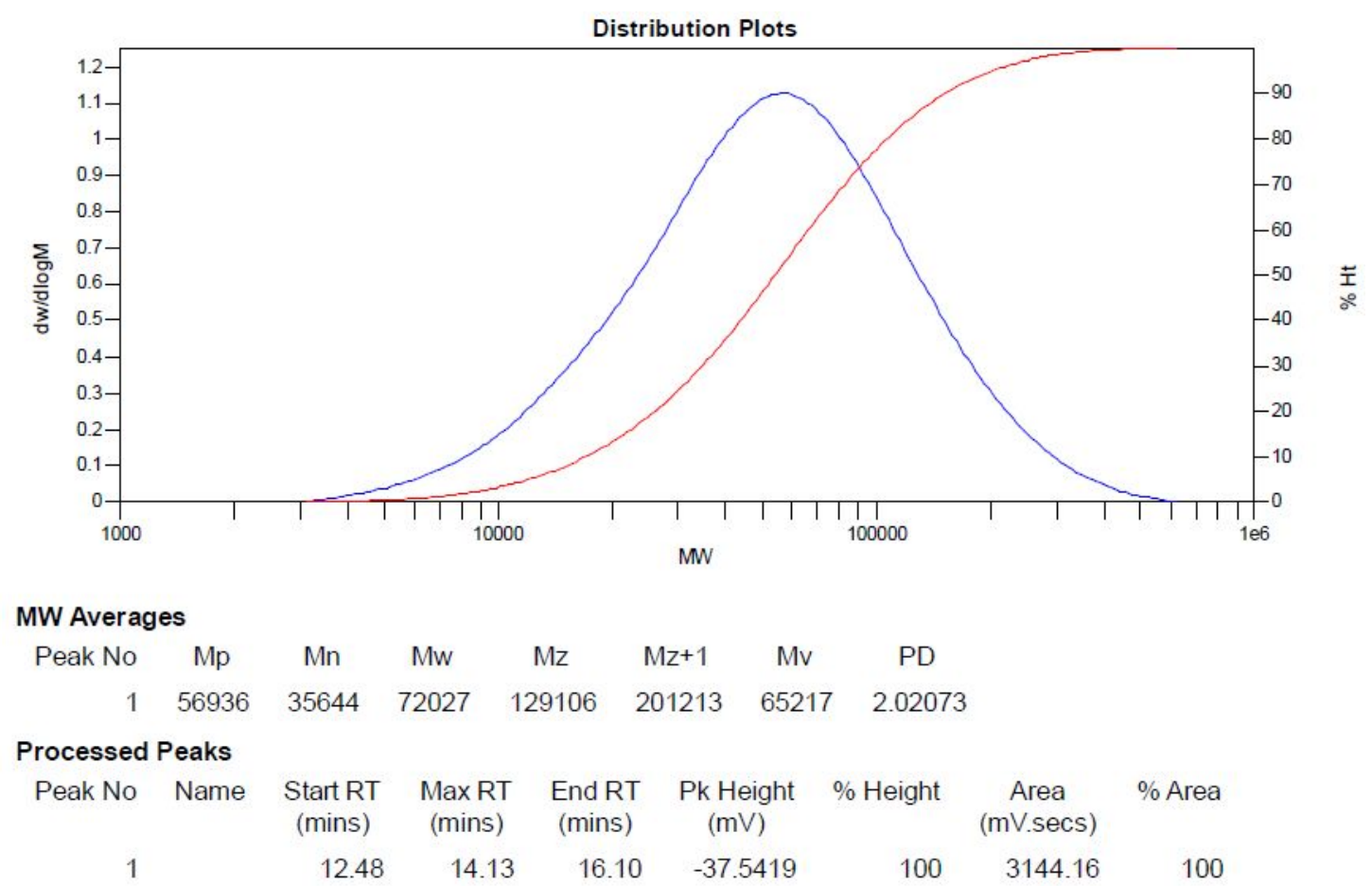

Figure S144. GPC data of the polymer from table 1, entry 7

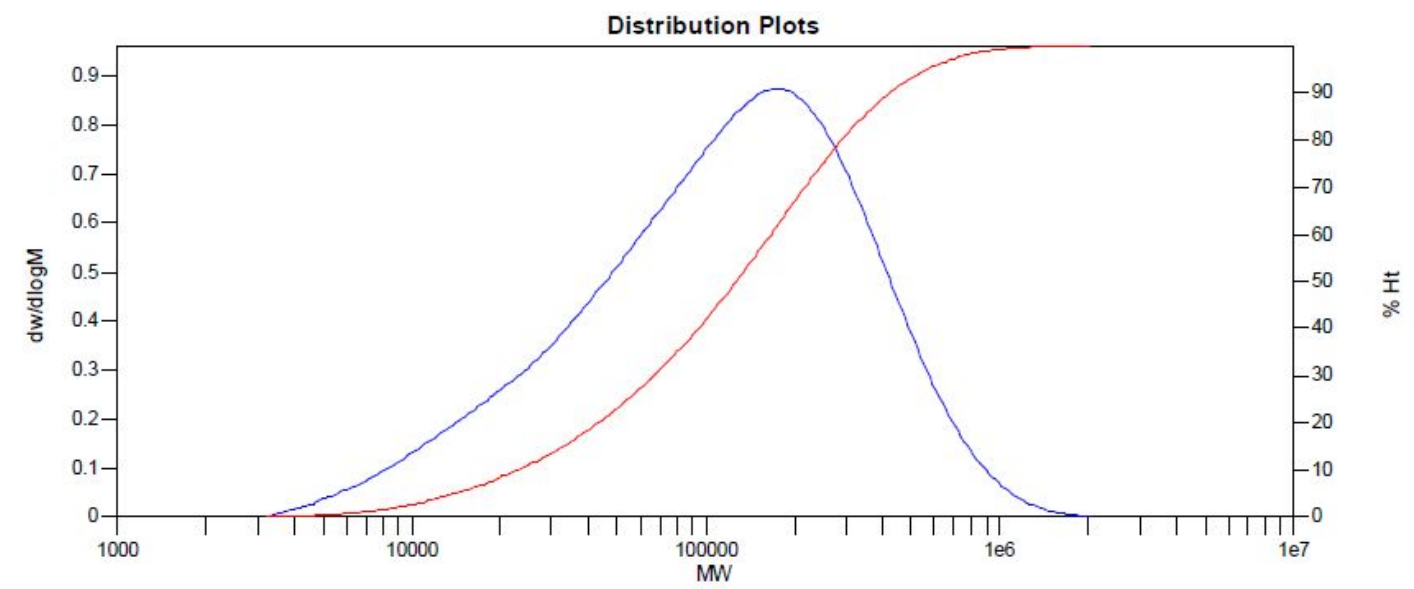

MW Averages

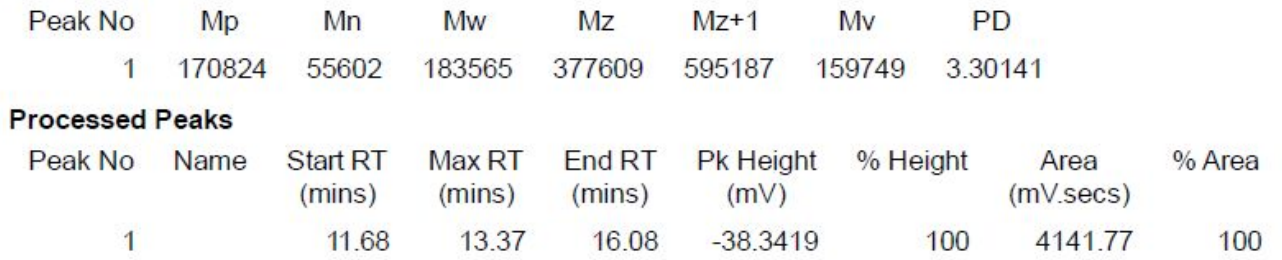

Figure S145. GPC data of the polymer from table 1, entry 8 


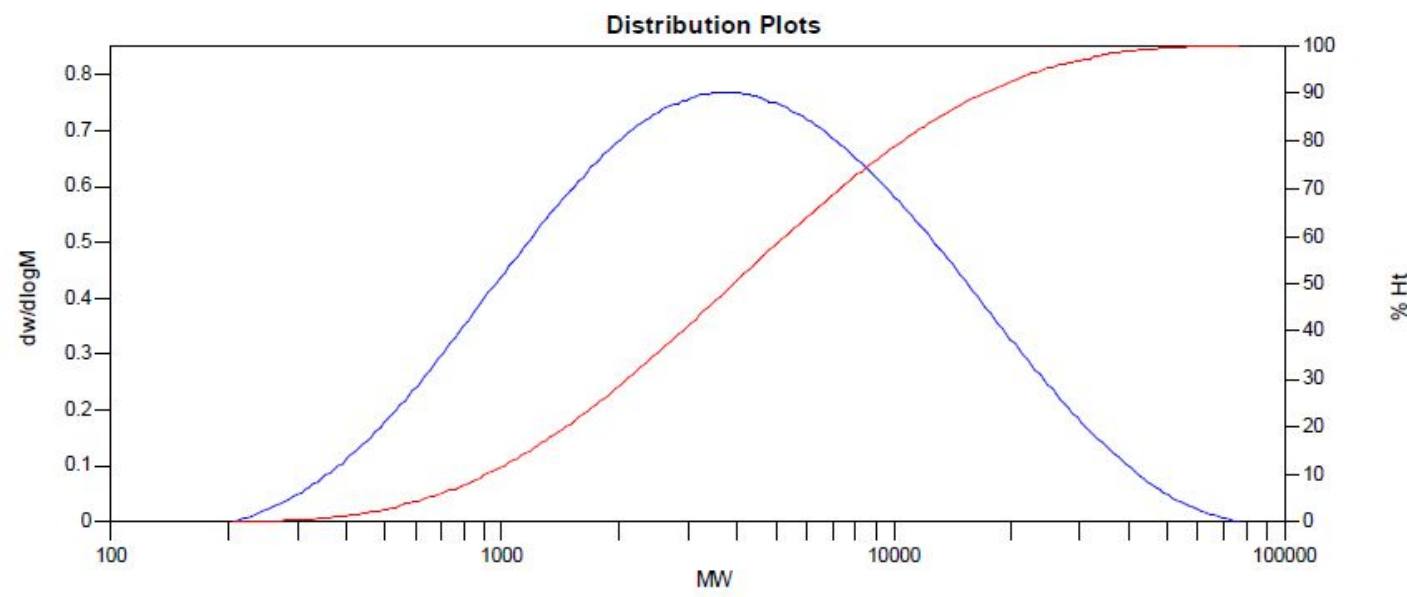

MW Averages

$\begin{array}{llllllll}\text { Peak No } & \mathrm{Mp} & \mathrm{Mn} & \mathrm{Mw} & \mathrm{Mz} & \mathrm{Mz}+1 & \mathrm{Mv} & \mathrm{PD}\end{array}$

$\begin{array}{llllllll}1 & 3607 & 2191 & 6865 & 16784 & 27878 & 5805 & 3.13327\end{array}$

\section{Processed Peaks}

$\begin{array}{ccccccccr}\text { Peak No } & \text { Name } & \begin{array}{c}\text { Start RT } \\ \text { (mins) }\end{array} & \begin{array}{c}\text { Max RT } \\ \text { (mins) }\end{array} & \begin{array}{c}\text { End RT } \\ \text { (mins) }\end{array} & \begin{array}{c}\text { Pk Height } \\ (\mathrm{mV})\end{array} & \% \text { Height } & \begin{array}{c}\text { Area } \\ \text { (mV.secs) }\end{array} & \text { \% Area } \\ 1 & 13.92 & 16.00 & 17.95 & -31.072 & 100 & 3821.92 & 100\end{array}$

Figure S146. GPC data of the polymer from table 1, entry 9

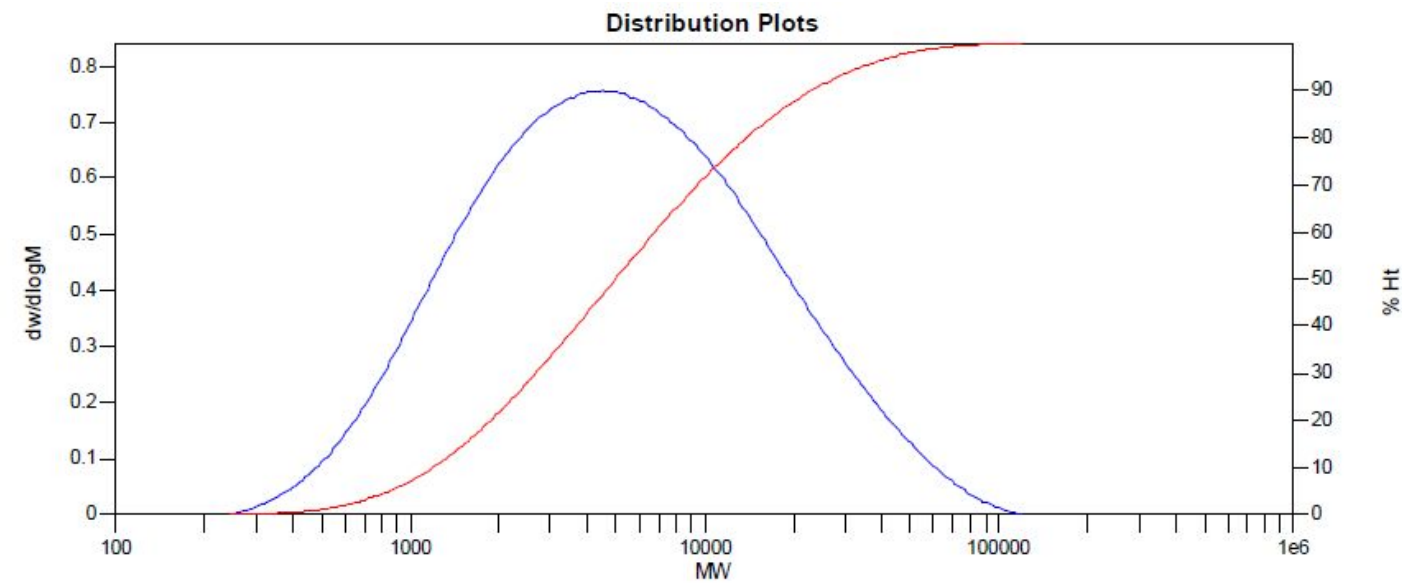

\section{MW Averages}

$\begin{array}{llllllll}\text { Peak No } & \mathrm{Mp} & \mathrm{Mn} & \mathrm{Mw} & \mathrm{Mz} & \mathrm{Mz}+1 & \mathrm{Mv} & \mathrm{PD}\end{array}$

$\begin{array}{llllllll}1 & 4493 & 2847 & 9283 & 24588 & 42539 & 7748 & 3.26063\end{array}$

\section{Processed Peaks}

$\begin{array}{ccccccccr}\text { Peak No Name } & \begin{array}{c}\text { Start RT } \\ \text { (mins) }\end{array} & \begin{array}{c}\text { Max RT } \\ \text { (mins) }\end{array} & \begin{array}{c}\text { End RT } \\ \text { (mins) }\end{array} & \begin{array}{c}\text { Pk Height } \\ (\mathrm{mV})\end{array} & \text { \% Height } & \begin{array}{c}\text { Area } \\ \text { (mV.secs) }\end{array} & \text { \% Area } \\ 1 & 13.62 & 15.85 & 17.83 & -32.4575 & 100 & 4050.45 & 100\end{array}$

Figure S147. GPC data of the polymer from table 1, entry 10. 


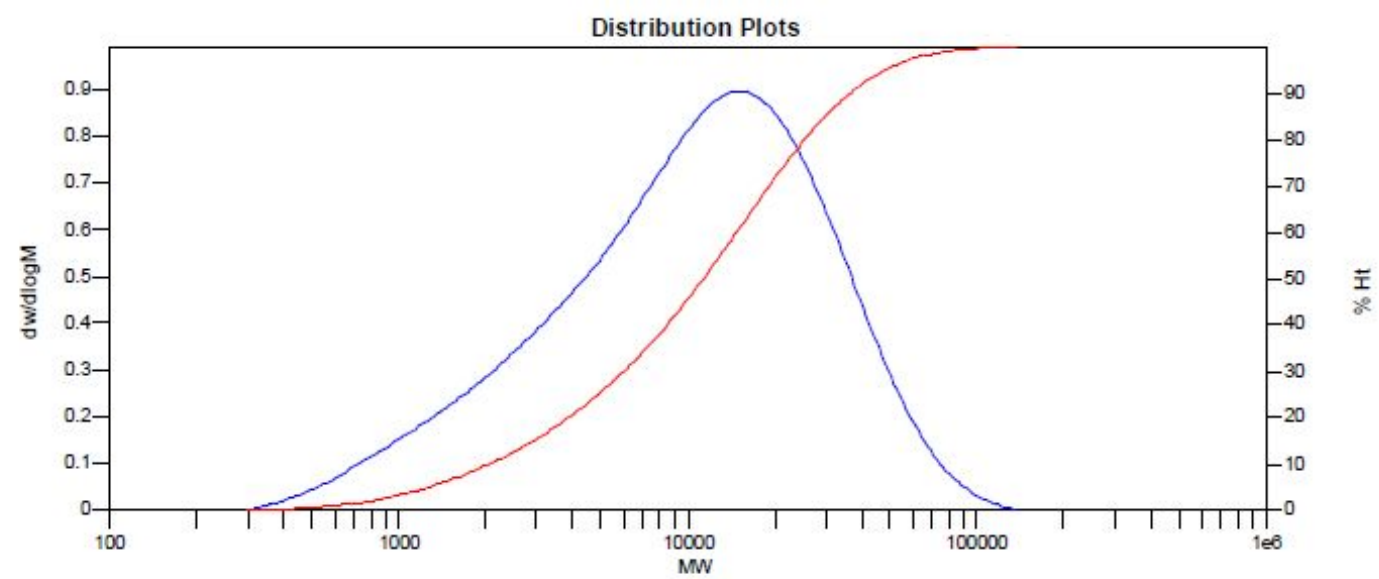

MW Averages

$\begin{array}{llllllll}\text { Peak No } & \mathrm{Mp} & \mathrm{Mn} & \mathrm{Mw} & \mathrm{Mz} & \mathrm{Mz}+1 & \mathrm{Mv} & \mathrm{PD}\end{array}$

$\begin{array}{llllllll}1 & 14866 & 5025 & 15862 & 31060 & 46609 & 13907 & 3.15662\end{array}$

Processed Peaks

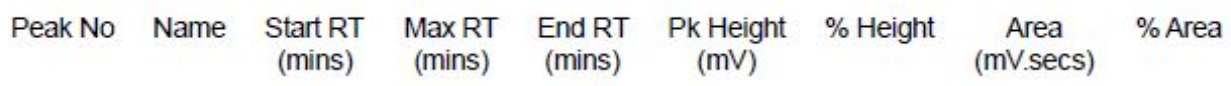

$\begin{array}{llllllll}1 & 13.52 & 15.03 & 17.70 & -38.2176 & 100 & 4019.61 & 100\end{array}$

Figure S148. GPC data of the polymer from table 1, entry 11

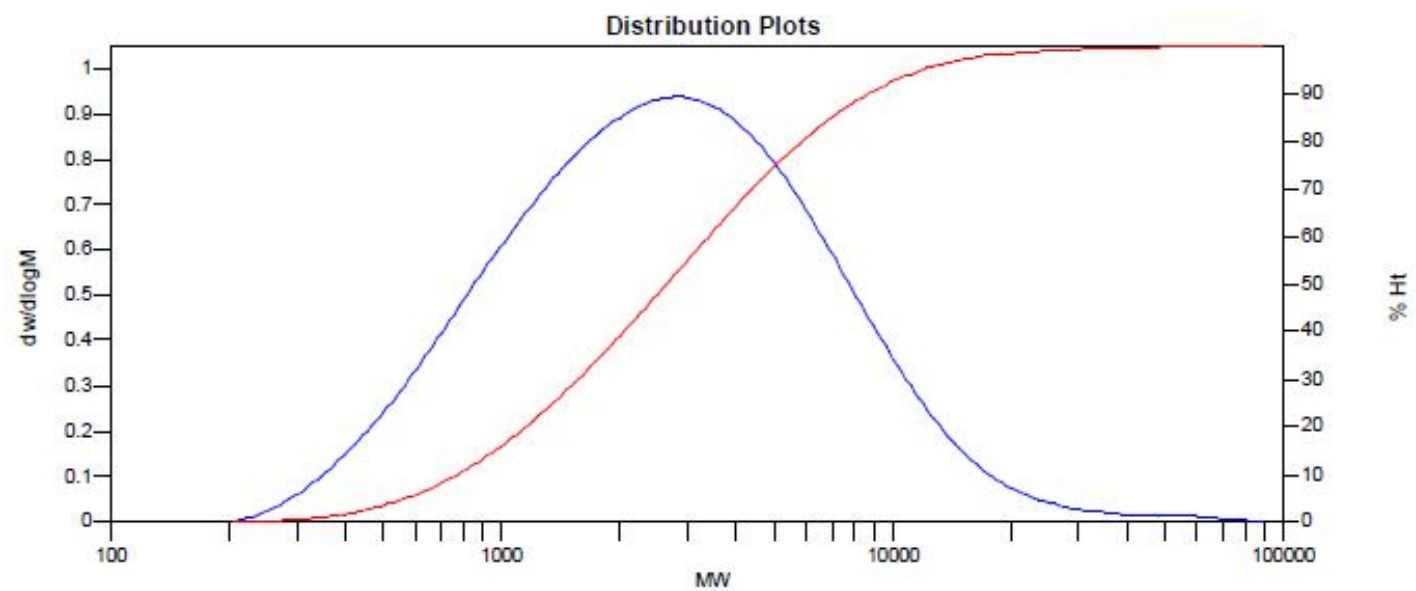

MW Averages

$\begin{array}{rccccccccc}\text { Peak No } & \text { Mp } & \text { Mn } & \text { Mw } & \text { Mz } & \text { Mz+1 } & \text { Mv } & \text { PD } & \\ 1 & 2825 & 1724 & 4047 & 10092 & 23900 & 3523 & 2.34745 & & \\ \text { Processed Peaks } & & & & & & & & \\ \text { Peak No } & \text { Name } & \begin{array}{c}\text { Start RT } \\ \text { (mins) }\end{array} & \begin{array}{c}\text { Max RT } \\ \text { (mins) }\end{array} & \begin{array}{c}\text { End RT } \\ \text { (mins) }\end{array} & \begin{array}{c}\text { Pk Height } \\ \text { (mV) }\end{array} & \% \text { Height } & \begin{array}{c}\text { Area } \\ \text { (mV.secs) }\end{array} & \text { \% Area } \\ 1 & & 13.82 & 16.17 & 17.95 & -38.7072 & 100 & 3894.1 & 100\end{array}$

Figure S149. GPC data of the polymer from table 1, entry 13 


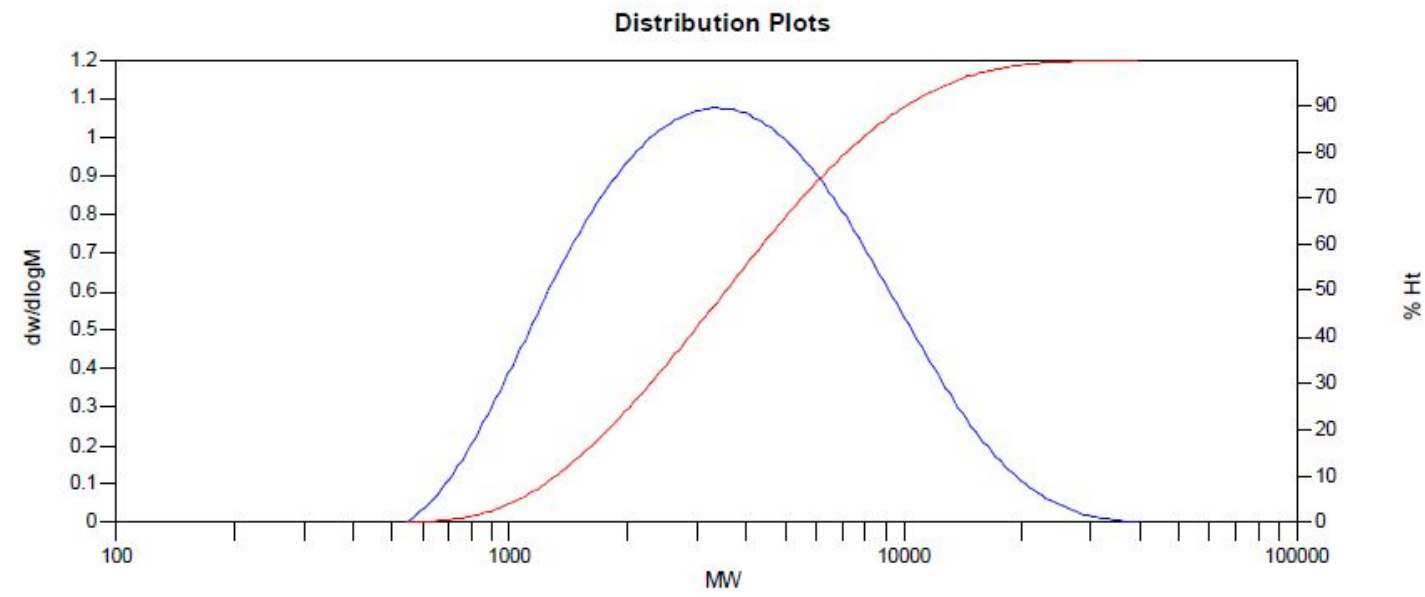

MW Averages

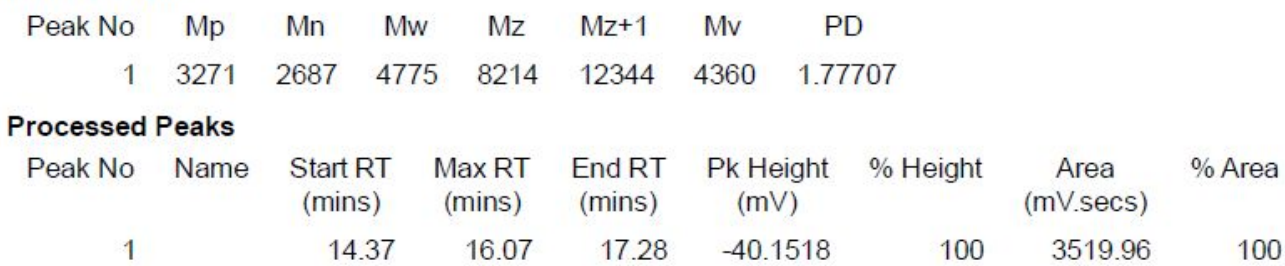

Figure S150. GPC data of the polymer from table 1, entry 15.

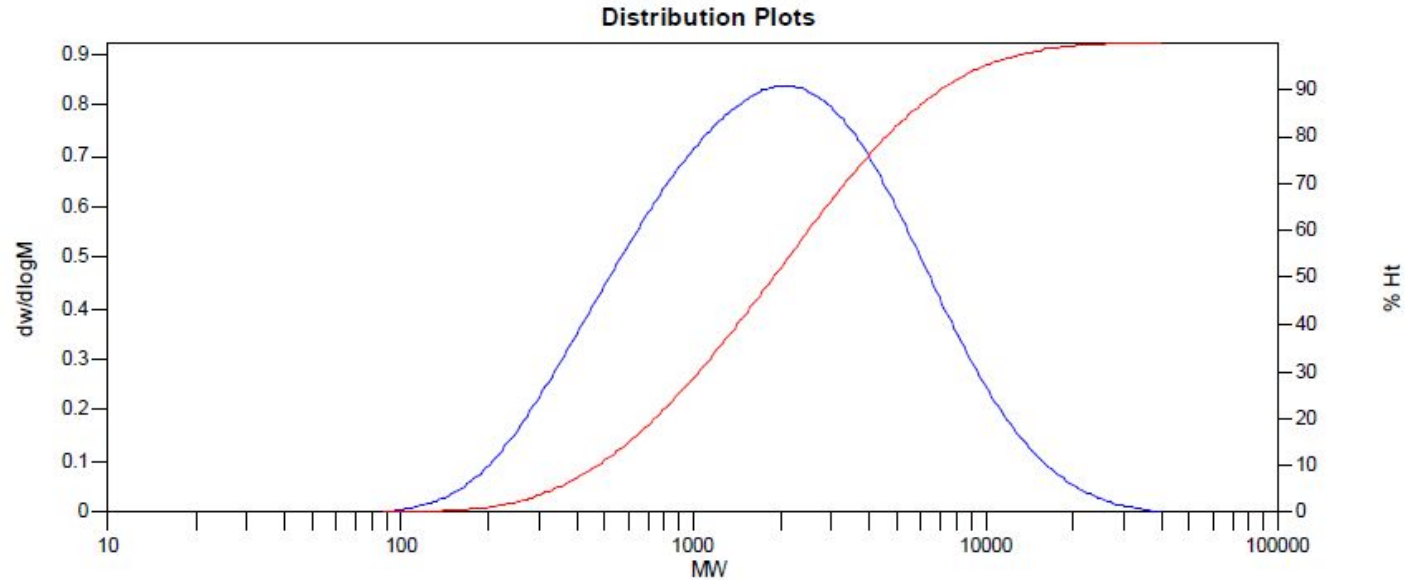

MW Averages

$\begin{array}{llllllll}\text { Peak No } & \mathrm{Mp} & \mathrm{Mn} & \mathrm{Mw} & \mathrm{Mz} & \mathrm{Mz}+1 & \mathrm{Mv} & \mathrm{PD}\end{array}$

$\begin{array}{llllllll}1 & 2007 & 1106 & 3024 & 6980 & 12222 & 2607 & 2.73418\end{array}$

Processed Peaks

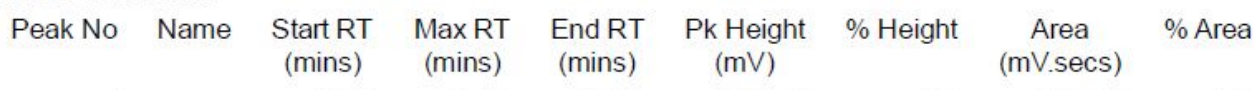

$\begin{array}{llllllll}1 & 14.37 & 16.40 & 18.53 & -39.7896 & 100 & 4482.71 & 100\end{array}$

Figure S151. GPC data of the polymer from table 1, entry 17. 


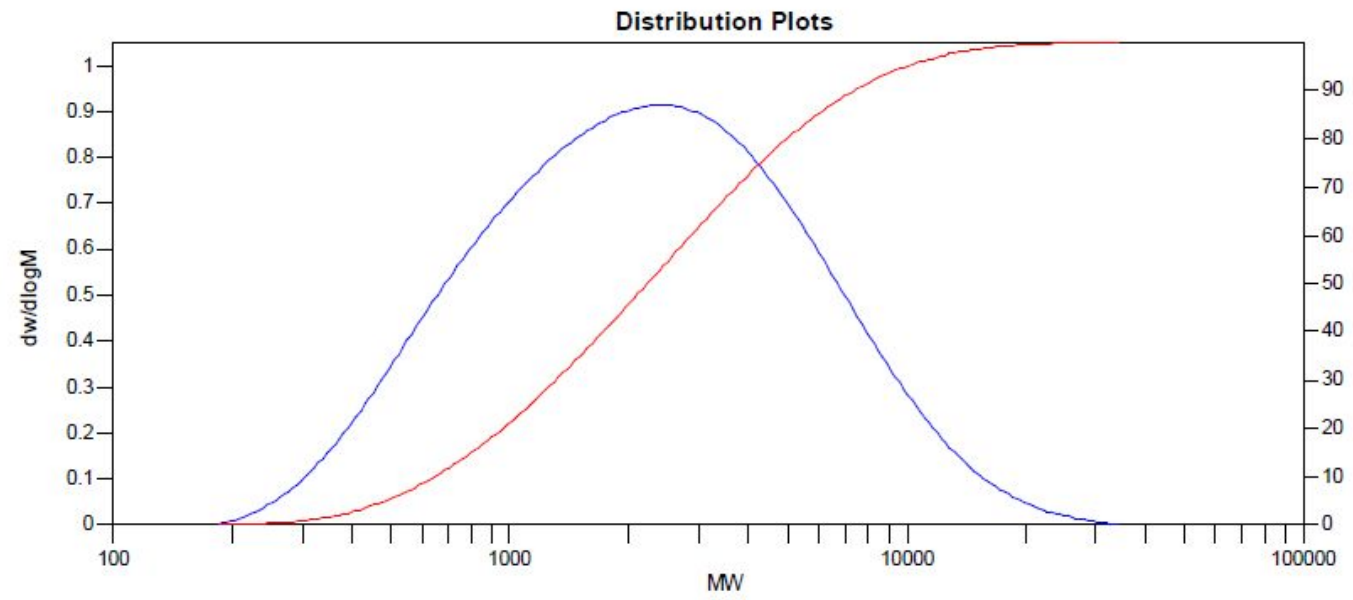

MW Averages

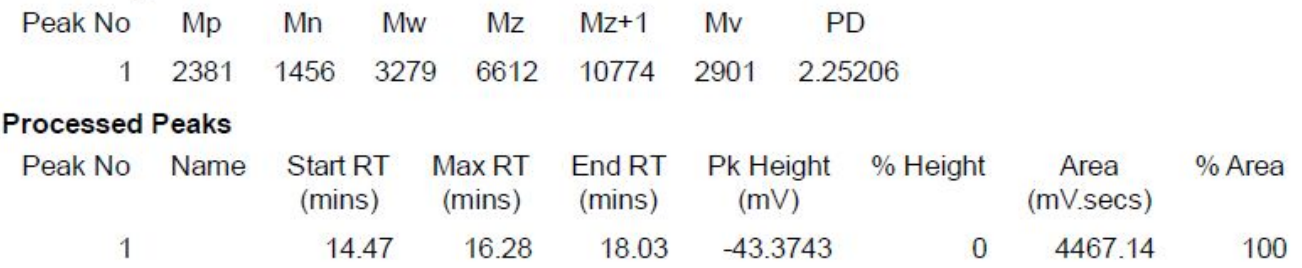

Figure S152. GPC data of the polymer from table 1, entry 18.
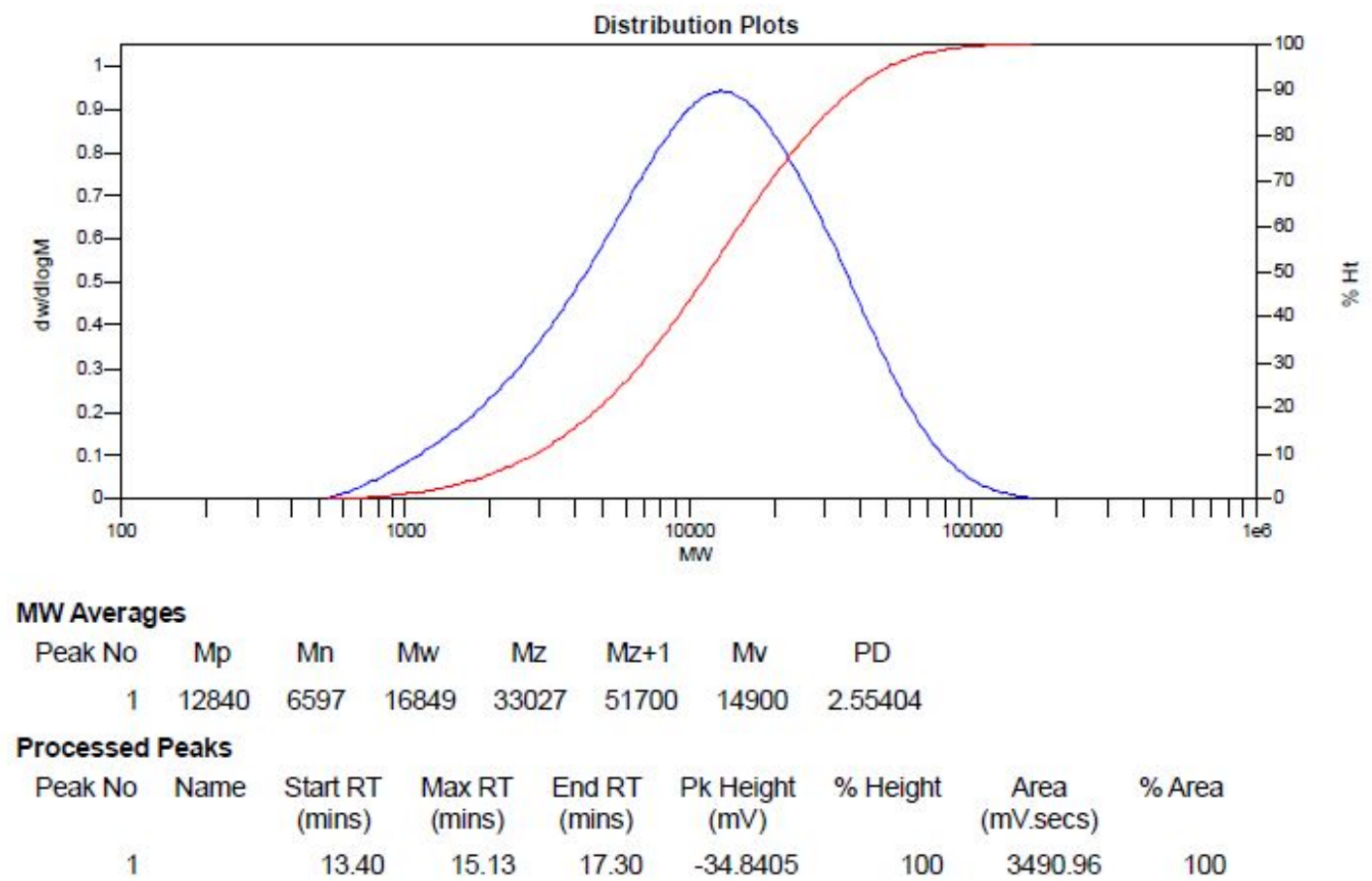

Figure S153. GPC data of the polymer from table 1, entry 19 


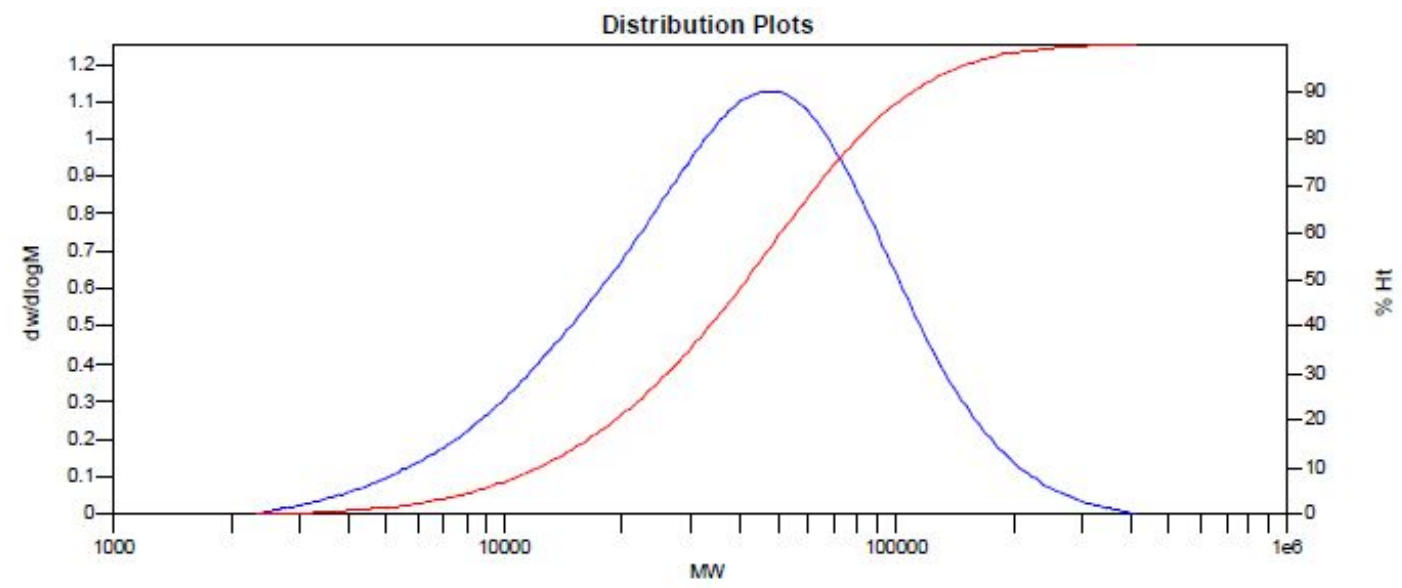

\section{MW Averages}

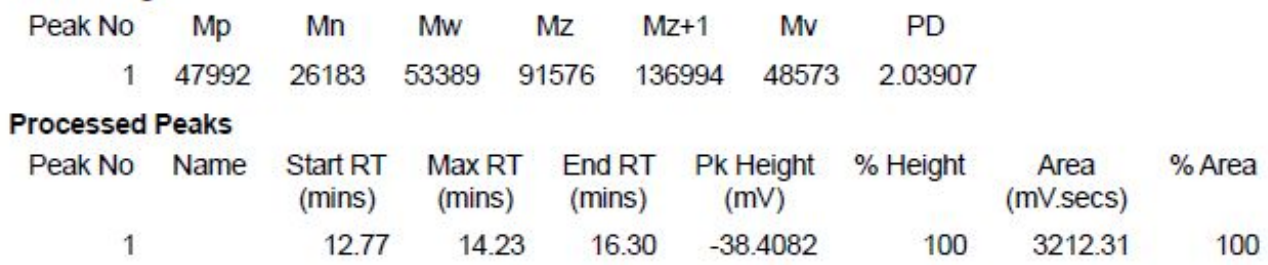

Figure S154. GPC data of the polymer from table 1, entry 20

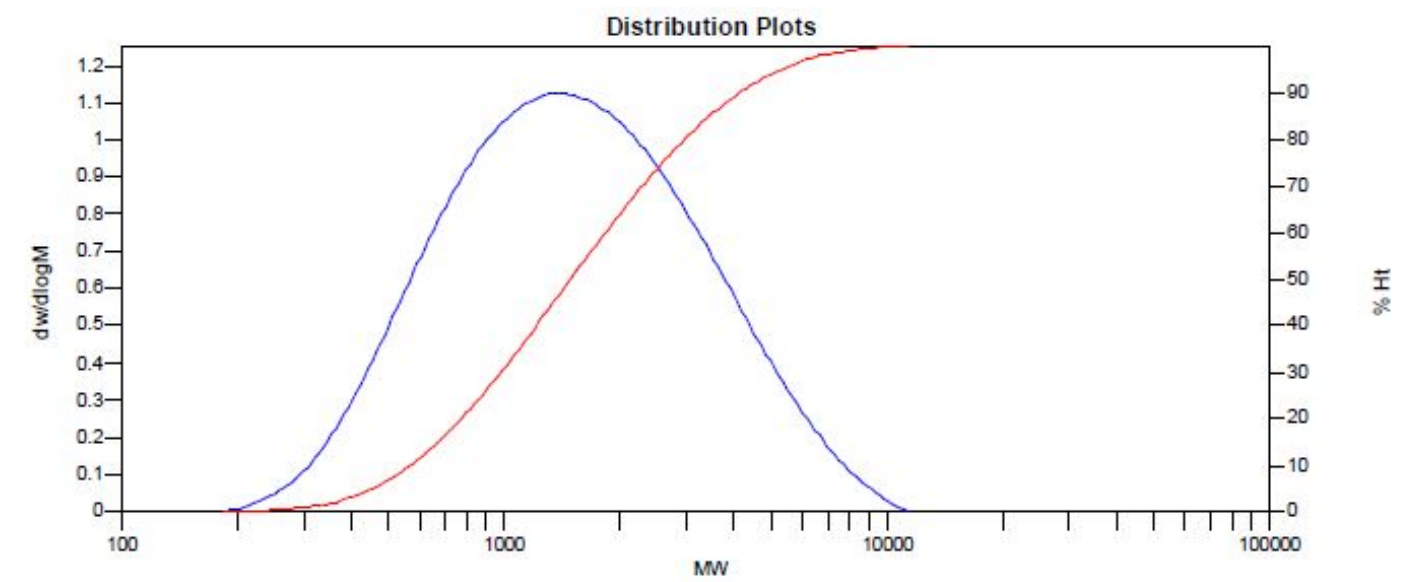

MW Averages

\begin{tabular}{|c|c|c|c|c|c|c|c|c|c|c|}
\hline Peak No & $\mathrm{Mp}$ & $\mathrm{Mn}$ & $M w$ & $M z$ & $\mathrm{Mz}+1$ & $\mathrm{Mv}$ & \multicolumn{2}{|c|}{ PD } & & \\
\hline 1 & 1392 & 1142 & 1961 & 3194 & 4538 & 1804 & \multicolumn{2}{|c|}{1.71716} & & \\
\hline \multicolumn{11}{|c|}{ Processed Peaks } \\
\hline Peak No & Name & $\begin{array}{r}\text { Start F } \\
(\text { mins }\end{array}$ & & $\begin{array}{c}\text { Max RT } \\
\text { (mins) }\end{array}$ & $\begin{array}{c}\text { End RT } \\
\text { (mins) }\end{array}$ & $\begin{array}{r}\mathrm{Pk} F \\
(\mathrm{~m}\end{array}$ & eight & $\%$ Height & $\begin{array}{c}\text { Area } \\
\text { (mV.secs) }\end{array}$ & $\%$ Area \\
\hline 1 & & 15 & 22 & 16.65 & 18.03 & -21 & 0535 & 100 & 1766.57 & 100 \\
\hline
\end{tabular}

Figure S155. GPC data of the polymer from table 1, entry 21 

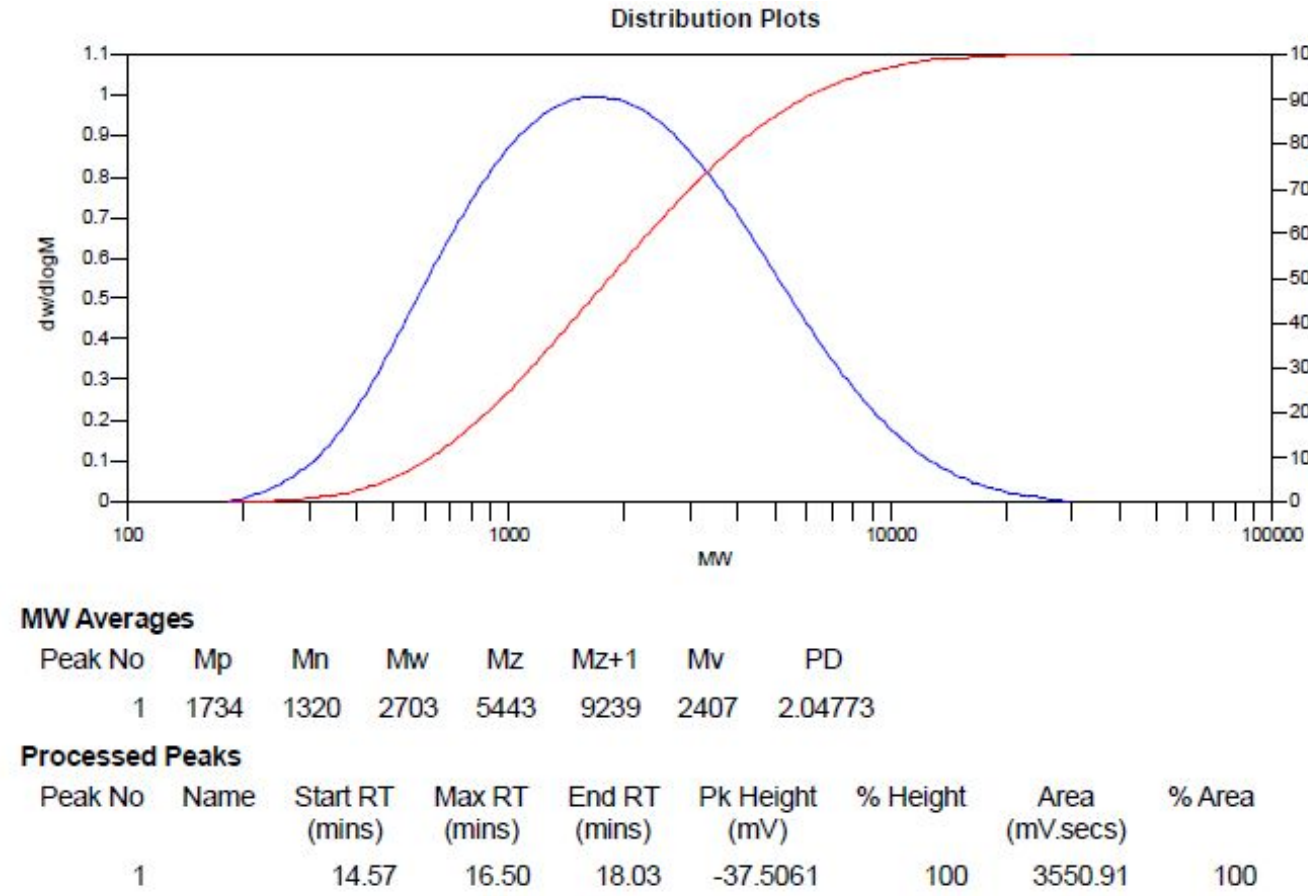

Figure S156. GPC data of the polymer from table 1, entry 22

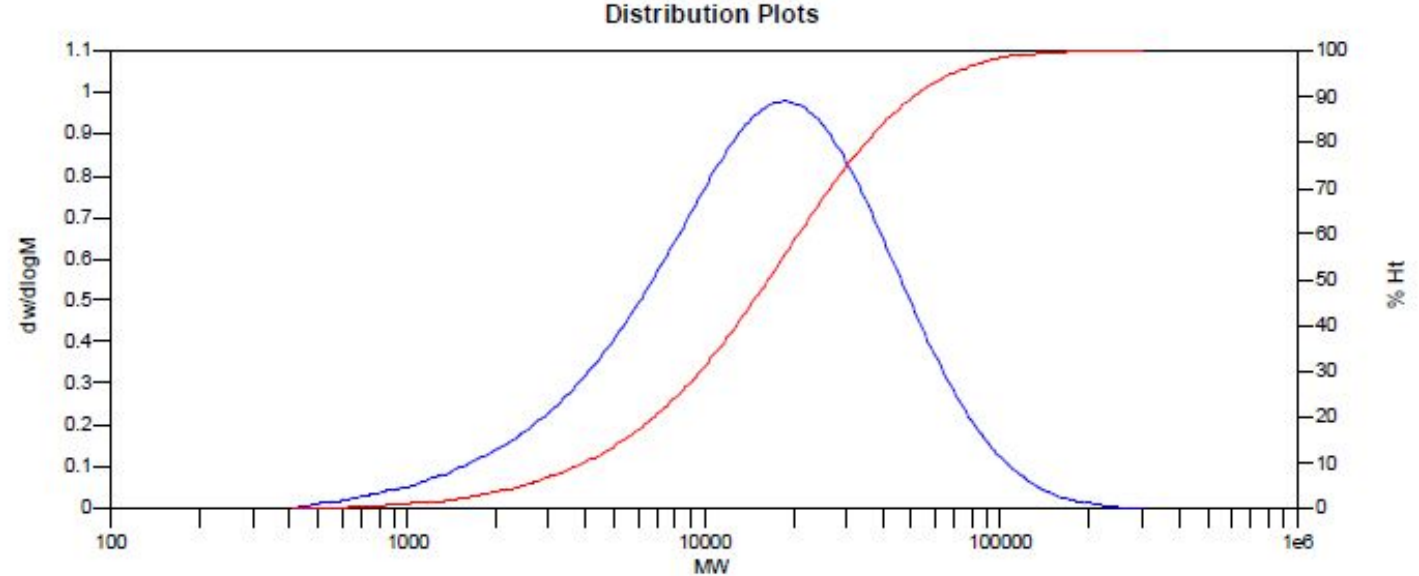

MW Averages

\begin{tabular}{|c|c|c|c|c|c|c|c|c|c|c|}
\hline \\
\hline Peak No & $\mathrm{Mp}$ & $\mathrm{Mn}$ & Mw & \multicolumn{2}{|c|}{$M z$} & $\mathrm{Mz}+1$ & Mv & PD & & \\
\hline 1 & 18519 & 8453 & 23245 & 466 & 75 & 77521 & 20527 & 2.74991 & & \\
\hline \multicolumn{11}{|c|}{ Processed Peaks } \\
\hline \multirow[t]{2}{*}{ Peak No } & Name & $\begin{array}{l}\text { Start RT } \\
\text { (mins) }\end{array}$ & $\begin{array}{r}\text { Max } \\
\text { (mi }\end{array}$ & & & $\begin{array}{l}\text { RT } \\
\text { ns) }\end{array}$ & $\begin{array}{l}\text { Pk Height } \\
(\mathrm{mV})\end{array}$ & $\%$ Height & $\begin{array}{c}\text { Area } \\
\text { (mV.secs) }\end{array}$ & $\%$ Area \\
\hline & & 12.98 & & .88 & & 7.48 & -32.9484 & 100 & 3178.86 & 100 \\
\hline
\end{tabular}

Figure S157. GPC data of the polymer from table 2, entry 1 

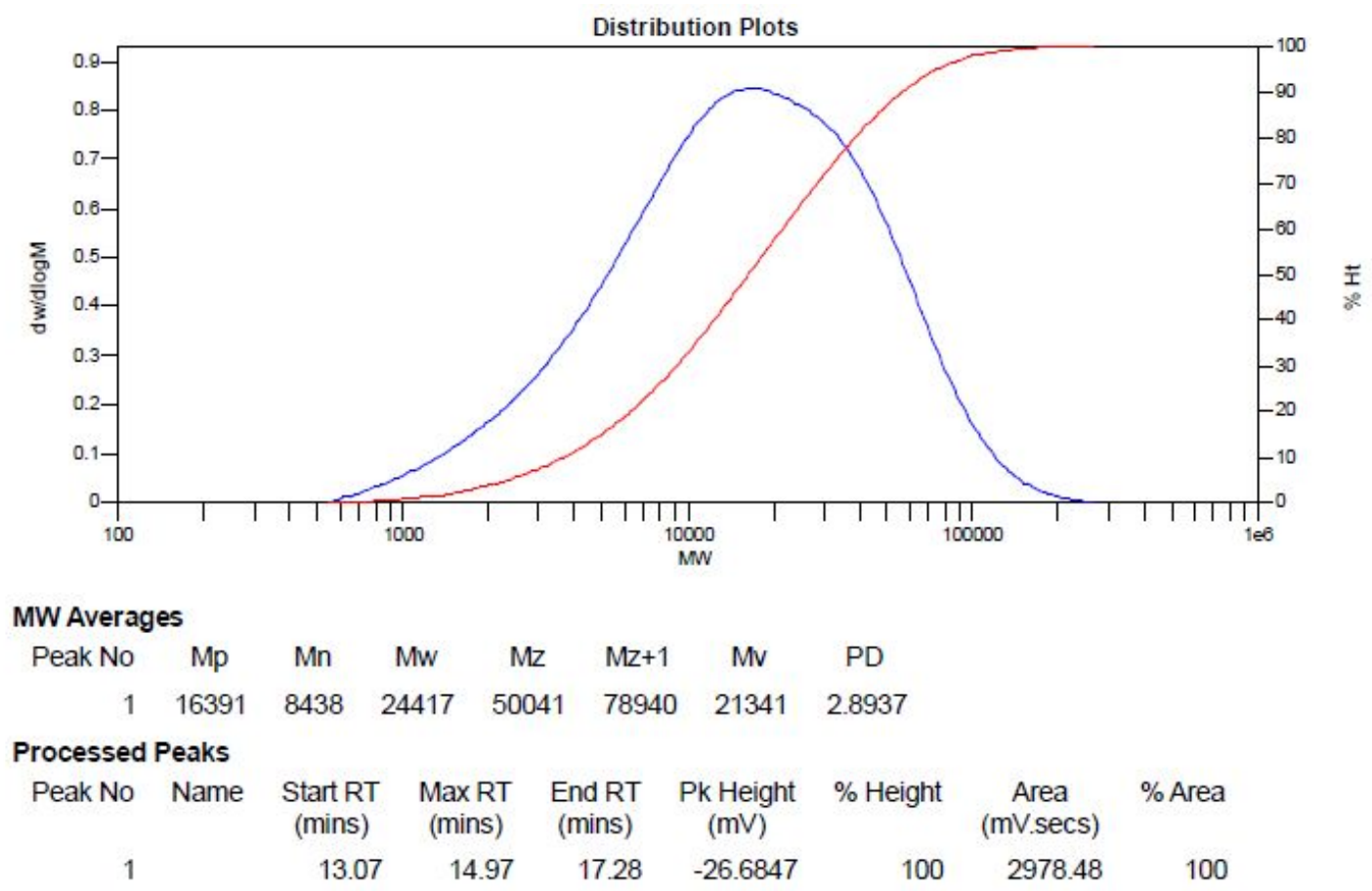

Figure S158. GPC data of the polymer from table 2, entry 2.
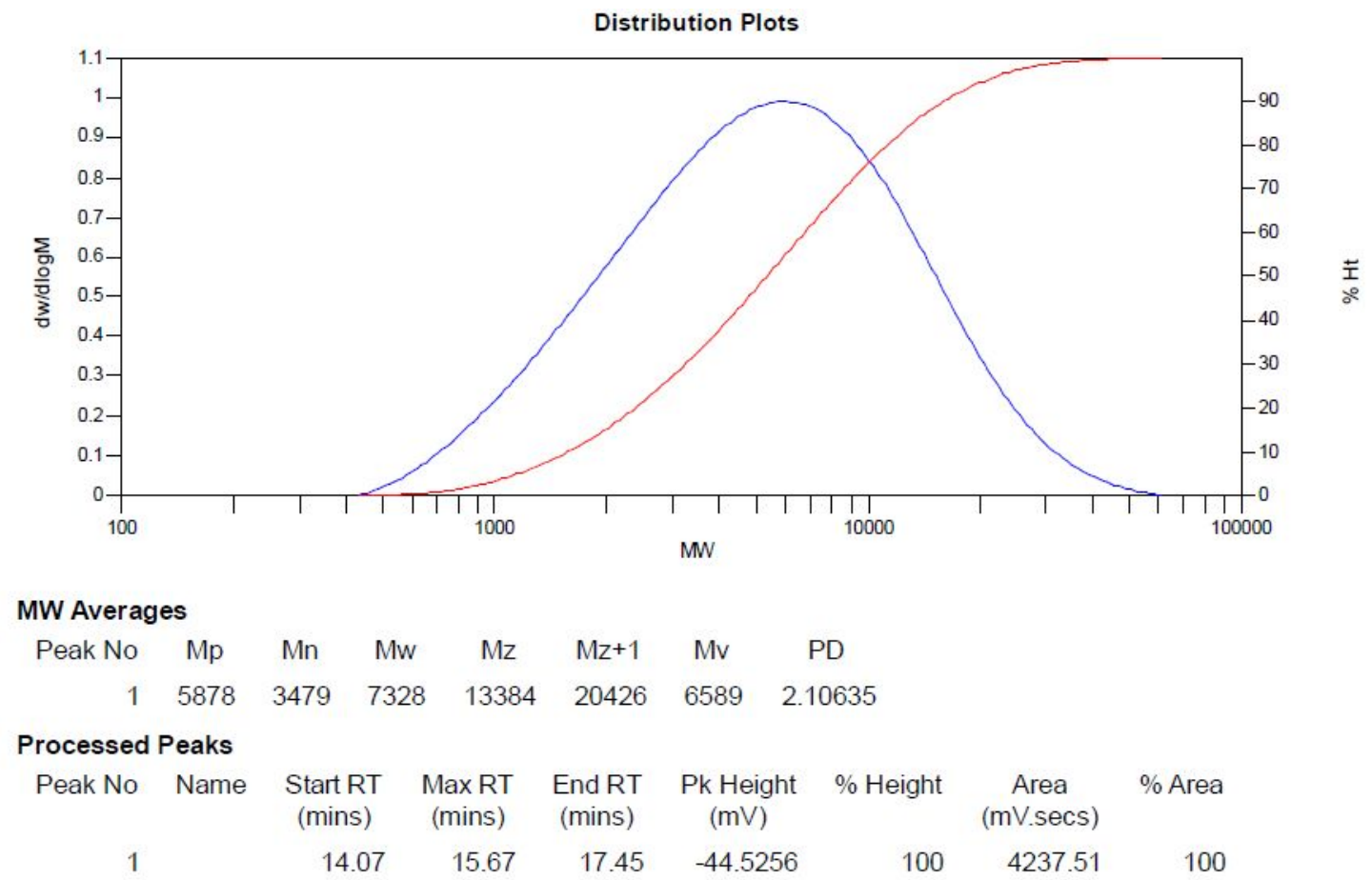

Figure S159. GPC data of the polymer from table 2, entry 3. 

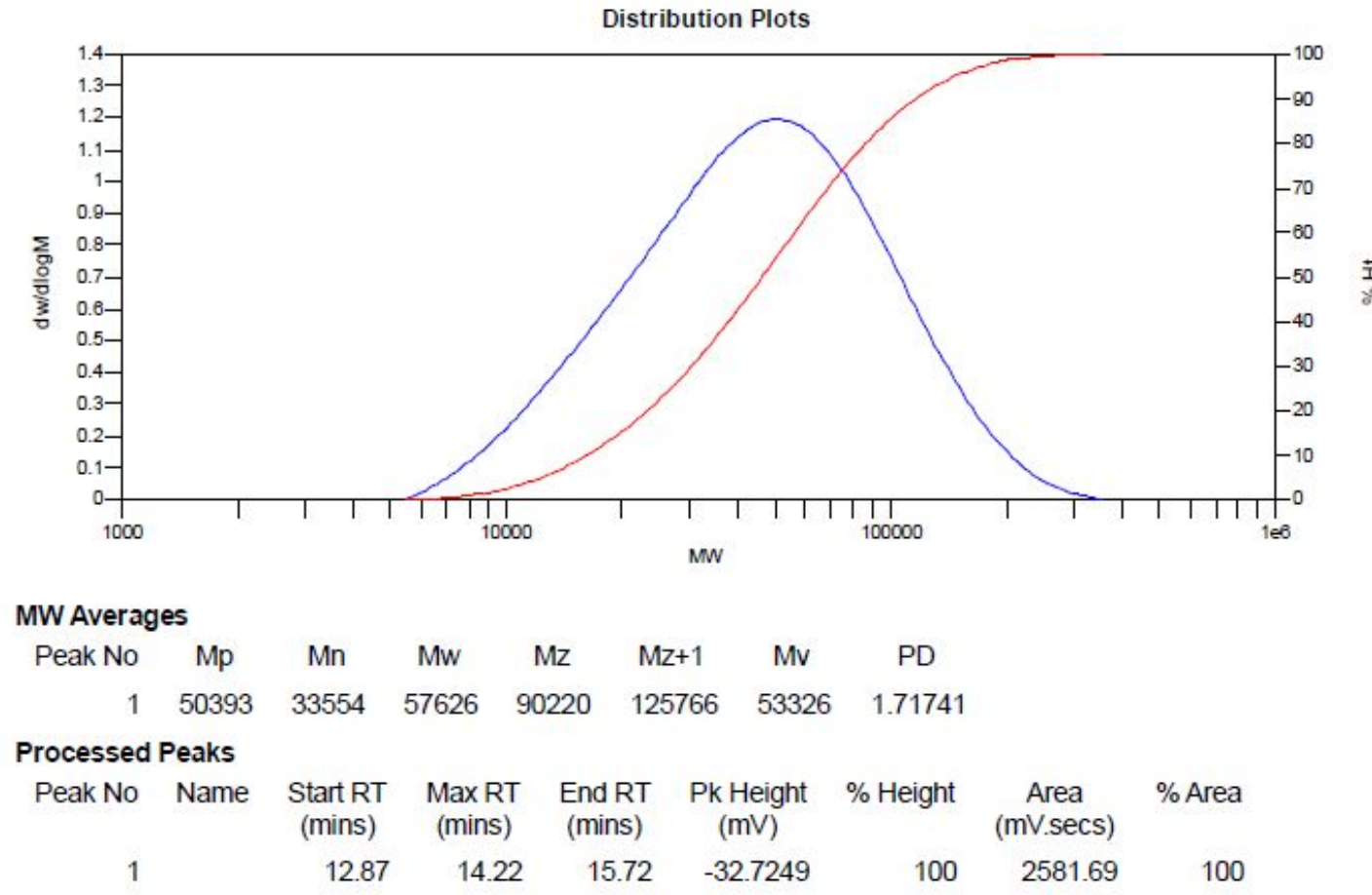

Figure S160. GPC data of the polymer from table 2, entry 4.

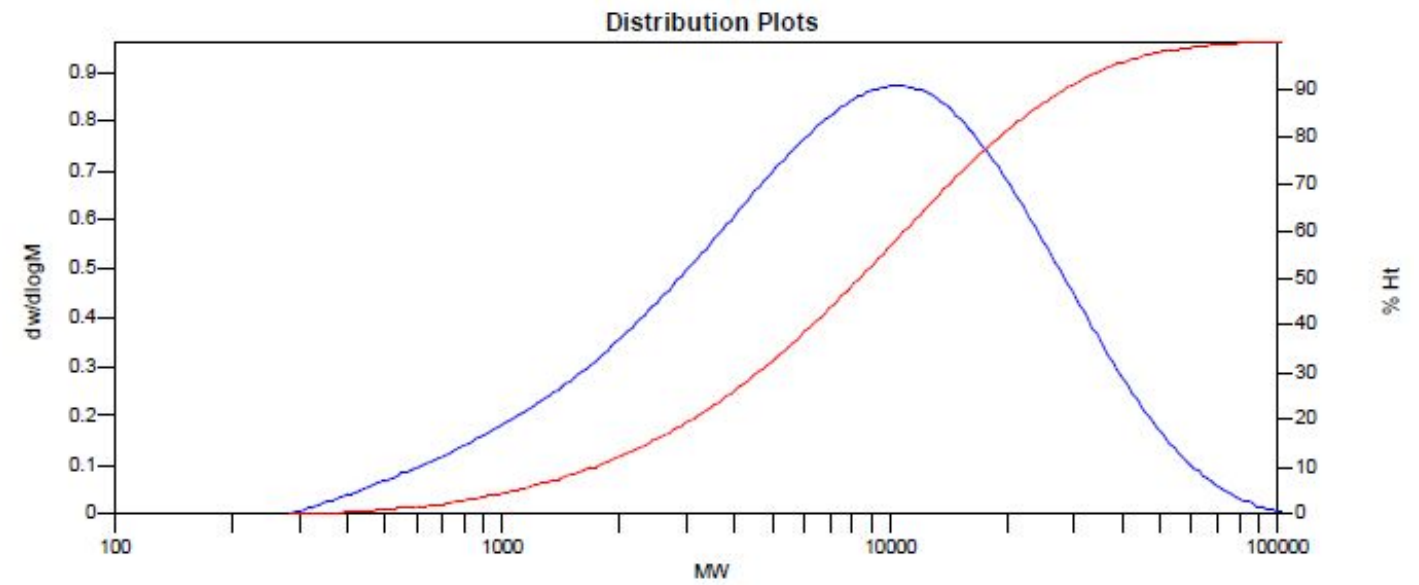

MW Averages

\begin{tabular}{|c|c|c|c|c|c|c|c|c|c|c|}
\hline \\
\hline Peak No & Mp & $\mathrm{Mn}$ & Mw & \multicolumn{2}{|c|}{$\mathrm{Mz}$} & $M z+1$ & Mv & PD & & \\
\hline 1 & 10307 & 4069 & 12205 & 24 & 85 & 37558 & 10673 & 2.99951 & & \\
\hline \multicolumn{11}{|c|}{ Processed Peaks } \\
\hline Peak No & Name & $\begin{array}{c}\text { Start RT } \\
\text { (mins) }\end{array}$ & $\begin{array}{r}\operatorname{Max} \\
(\mathrm{mi}\end{array}$ & & & $\begin{array}{l}\text { d RT } \\
\text { ins) }\end{array}$ & $\begin{array}{l}\text { Pk Height } \\
(\mathrm{mV})\end{array}$ & $\%$ Height & $\begin{array}{c}\text { Area } \\
\text { (mV.secs) }\end{array}$ & $\%$ Area \\
\hline 1 & & 13.70 & & 5.28 & & 17.73 & -33.608 & 100 & 3634.55 & 100 \\
\hline
\end{tabular}

Figure S161. GPC data of the polymer from table 2, entry 5 


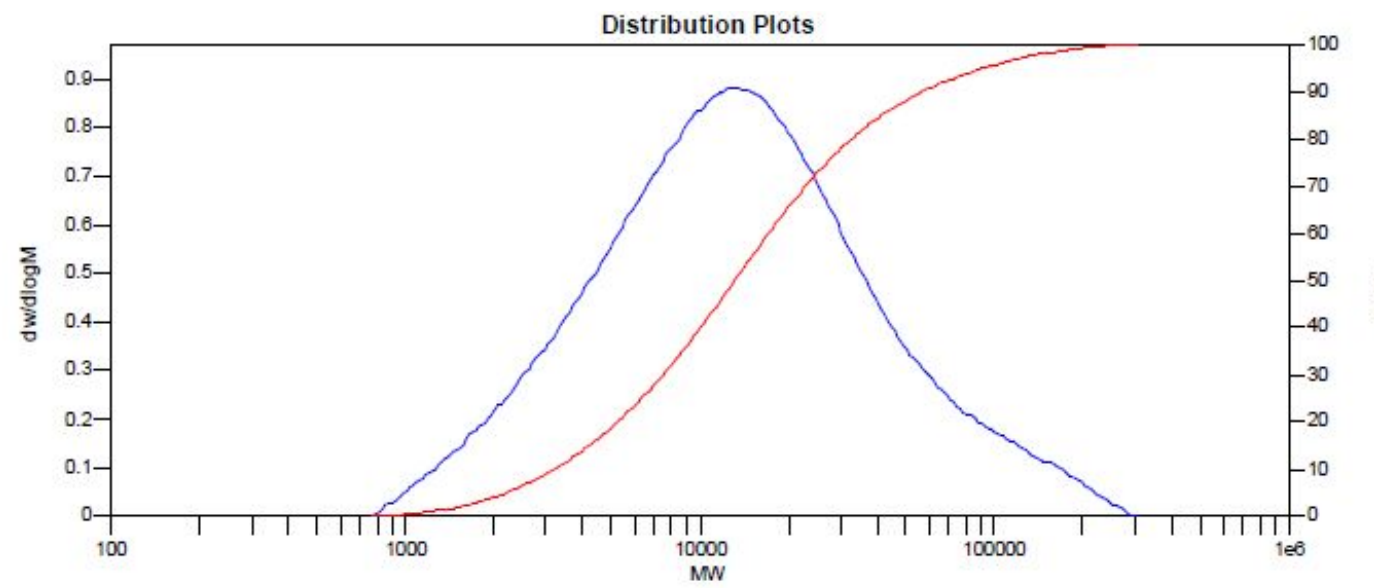

$\frac{1}{2}$

MW Averages

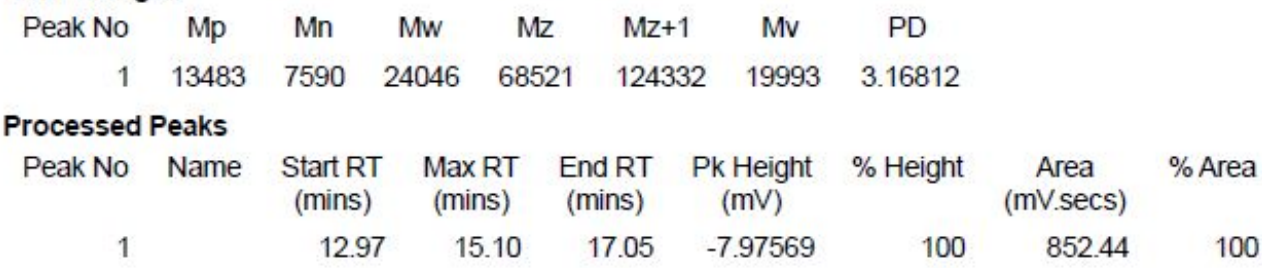

Figure S162. GPC data of the polymer from table 2, entry 6.
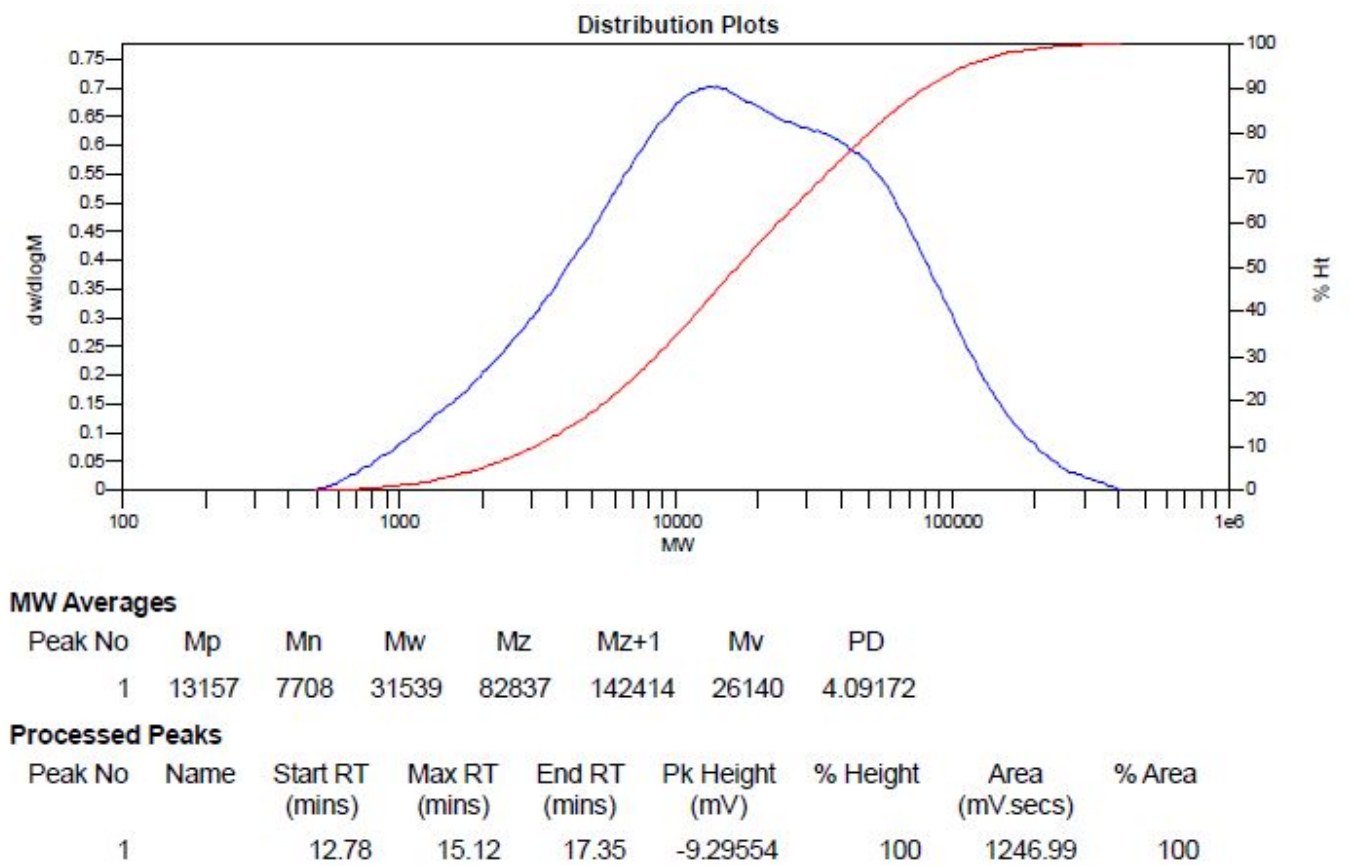

Figure S163. GPC data of the polymer from table 2, entry 7. 


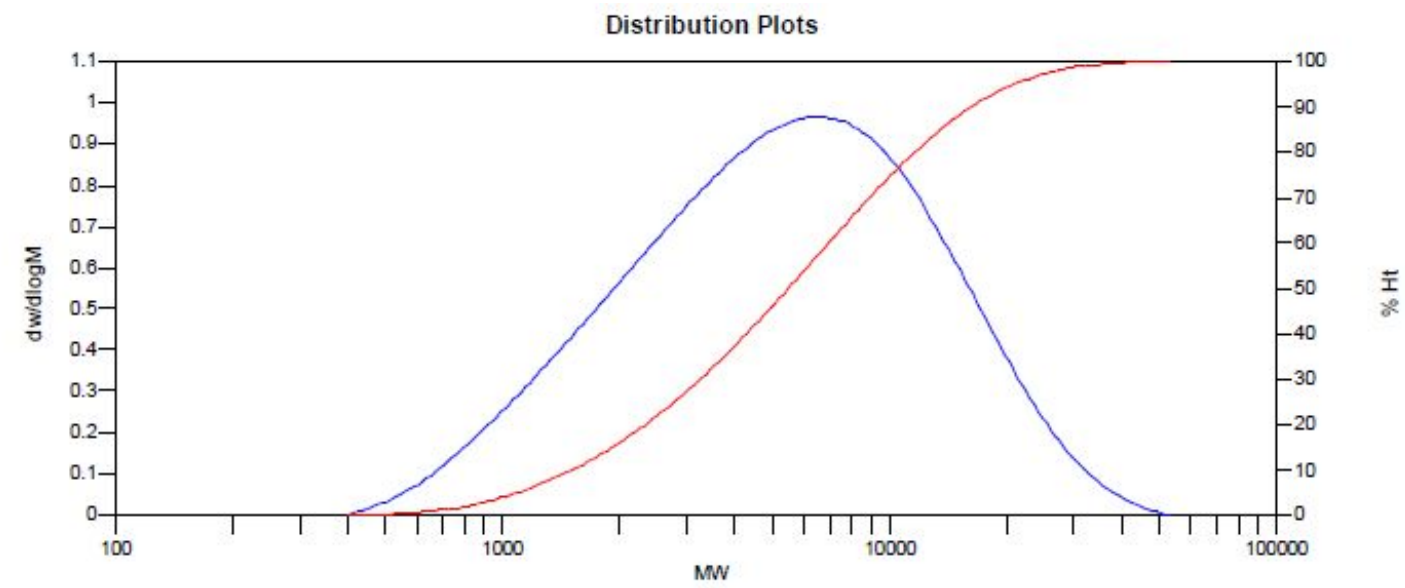

\section{MW Averages}

$\begin{array}{llllllll}\text { Peak No } & \mathrm{Mp} & \mathrm{Mn} & \mathrm{Mw} & \mathrm{Mz} & \mathrm{Mz}+1 & \mathrm{Mv} & \mathrm{PD}\end{array}$

$\begin{array}{llllllll}1 & 6325 & 3429 & 7443 & 13276 & 19330 & 6695 & 2.1706\end{array}$

\section{Processed Peaks}

$\begin{array}{ccccccccr}\text { Peak No } & \text { Name } & \begin{array}{c}\text { Start RT } \\ (\text { mins })\end{array} & \begin{array}{c}\text { Max RT } \\ (\text { mins })\end{array} & \begin{array}{c}\text { End RT } \\ (\text { mins })\end{array} & \begin{array}{c}\text { Pk Height } \\ (\mathrm{mV})\end{array} & \% \text { Height } & \begin{array}{c}\text { Area } \\ \text { (mV.secs) }\end{array} & \% \text { Area } \\ 1 & 14.17 & 15.60 & 17.50 & -36.8122 & 100 & 3595.28 & 100\end{array}$

Figure S164. GPC data of the polymer from table 2, entry 8 .

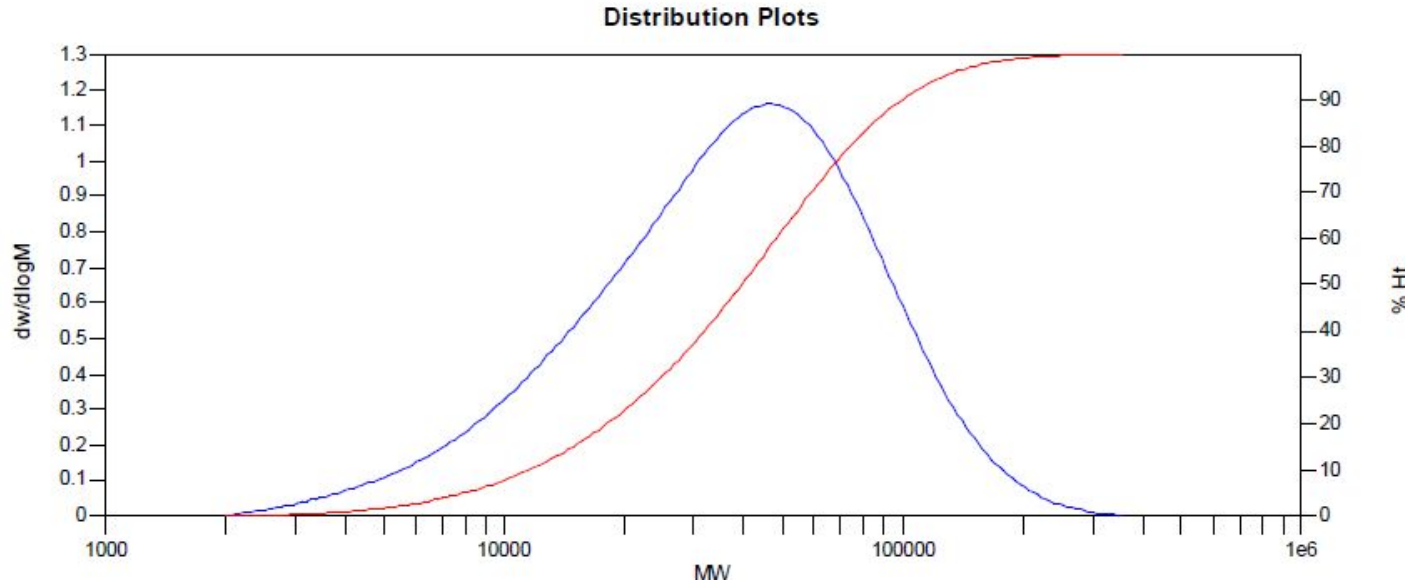

MW Averages

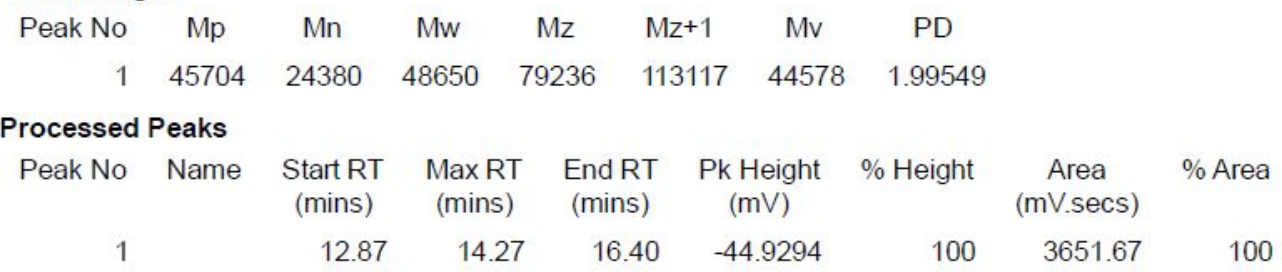

Figure S165. GPC data of the polymer from table 2, entry 9. 


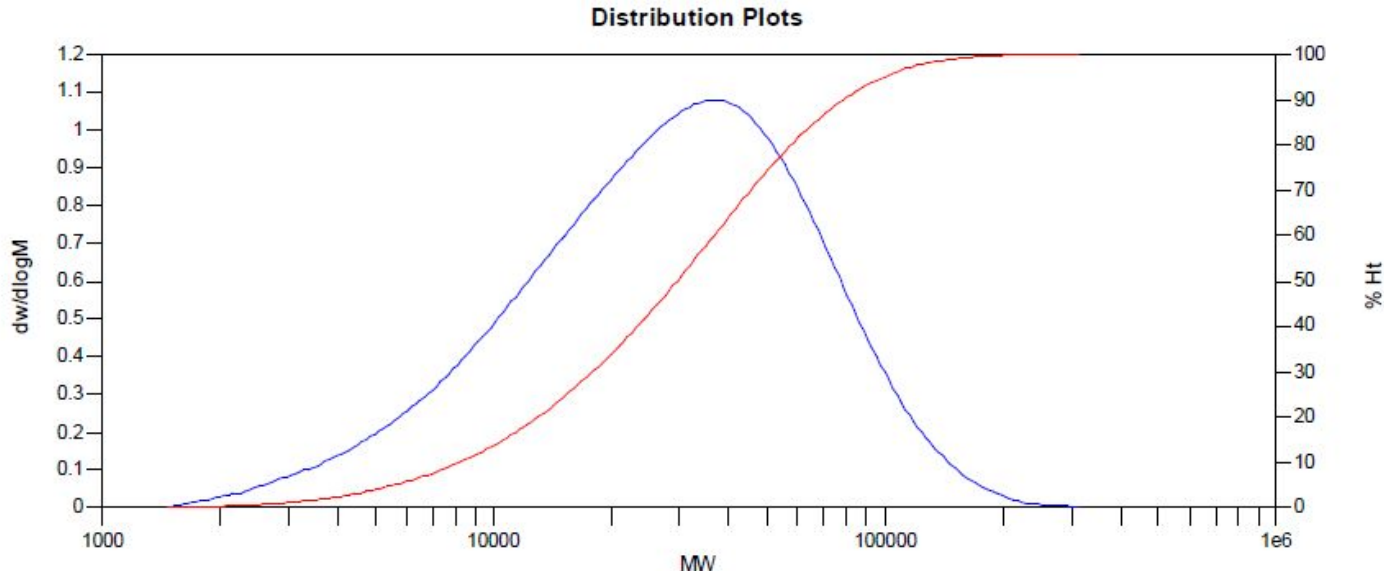

MW Averages

\begin{tabular}{|c|c|c|c|c|c|c|c|c|c|}
\hline Peak No & $\mathrm{Mp}$ & $\mathrm{Mn}$ & Mw & Mz & $\mathrm{Mz}$ & Mv & PD & & \\
\hline 1 & 36688 & 17719 & 37513 & 63364 & 918 & 34110 & 2.11711 & & \\
\hline \multicolumn{10}{|c|}{ Processed Peaks } \\
\hline Peak No & Name & $\begin{array}{c}\text { Start RT } \\
\text { (mins) }\end{array}$ & $\begin{array}{r}\text { Max RT } \\
\text { (mins) }\end{array}$ & $\begin{array}{l}\text { End } \\
(\mathrm{mi}\end{array}$ & & $\begin{array}{l}\text { Pk Height } \\
\quad(\mathrm{mV})\end{array}$ & $\%$ Height & $\begin{array}{c}\text { Area } \\
(\mathrm{mV} \text {.secs })\end{array}$ & $\%$ Area \\
\hline 1 & & 12.95 & 14.42 & & 62 & -29.4786 & 0 & 2578.28 & \\
\hline
\end{tabular}

Figure S166. GPC data of the polymer from table 2, entry 10.

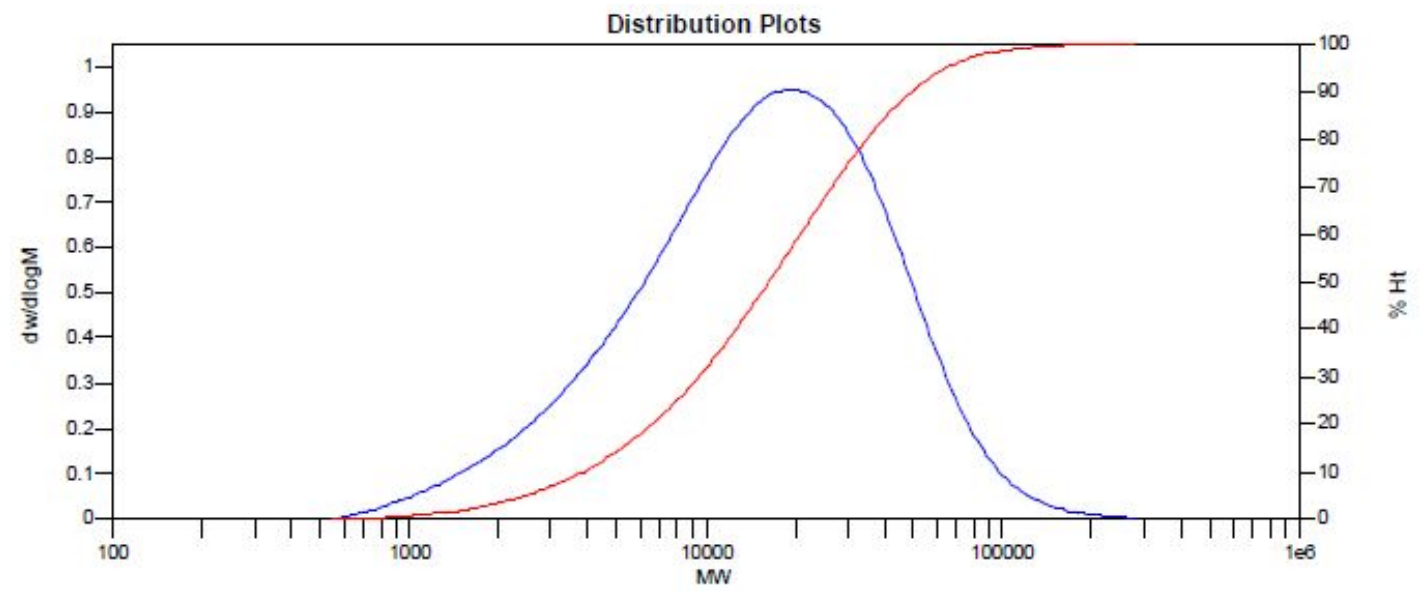

MW Averages

\begin{tabular}{|c|c|c|c|c|c|c|c|c|c|}
\hline Peak No & $\mathrm{Mp}$ & Mn & Mw & $\mathrm{Mz}$ & $\mathrm{Mz}+1$ & Mv & PD & & \\
\hline 1 & 18977 & 8681 & 22574 & 43965 & 72307 & 20026 & 2.60039 & & \\
\hline \multicolumn{10}{|c|}{ Processed Peaks } \\
\hline Peak No & Name & $\begin{array}{r}\text { Start RT } \\
\text { (mins) }\end{array}$ & $\begin{array}{r}\operatorname{Max} R^{-} \\
\text {(mins) }\end{array}$ & & $\begin{array}{l}\text { End RT } \\
\text { (mins) }\end{array}$ & $\begin{array}{l}\text { Pk Height } \\
(\mathrm{mV})\end{array}$ & $\%$ Height & $\begin{array}{c}\text { Area } \\
\text { (mV.secs) }\end{array}$ & $\%$ Area \\
\hline 1 & & 13.03 & 14.8 & & 17.28 & -40.4611 & 0 & 4009.68 & 100 \\
\hline
\end{tabular}

Figure S167. GPC data of the polymer from table 2, entry 12. 


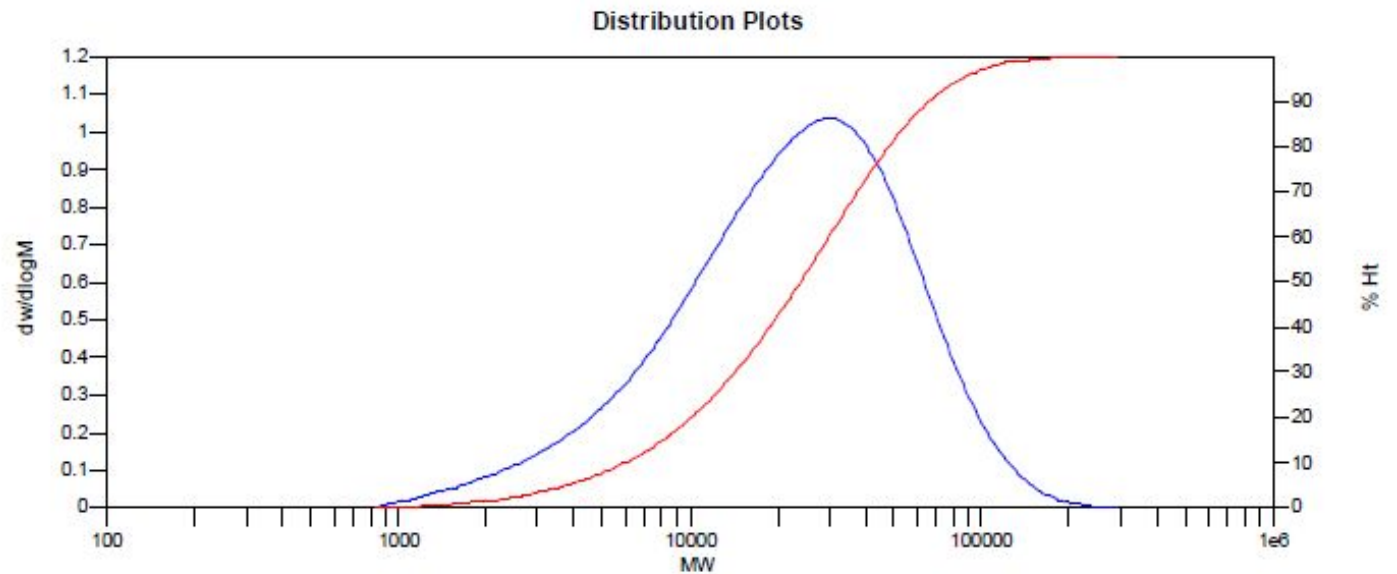

MW Averages

\begin{tabular}{|c|c|c|c|c|c|c|c|c|c|}
\hline Peak No & $\mathrm{Mp}$ & $\mathrm{Mn}$ & Mw & $\mathrm{Mz}$ & $\mathrm{Mz}+$ & Mv & PD & & \\
\hline 1 & 30178 & 12986 & 30959 & 54040 & 792 & 27927 & 2.38403 & & \\
\hline \multicolumn{10}{|c|}{ Processed Peaks } \\
\hline Peak No & Name & $\begin{array}{c}\text { Start RT } \\
\text { (mins) }\end{array}$ & $\begin{array}{r}\operatorname{Max} R T \\
\text { (mins) }\end{array}$ & $\begin{array}{l}\text { End } \\
\text { (mir }\end{array}$ & & $\begin{array}{l}\text { Pk Height } \\
(\mathrm{mV})\end{array}$ & $\%$ Height & $\begin{array}{c}\text { Area } \\
\text { (mV.secs) }\end{array}$ & $\%$ Area \\
\hline 1 & & 13.00 & 14.57 & & 7.00 & -43.2959 & 0 & 3942.7 & 100 \\
\hline
\end{tabular}

Figure S168. GPC data of the polymer from table 2, entry 13 


\section{X-ray Crystallography.}

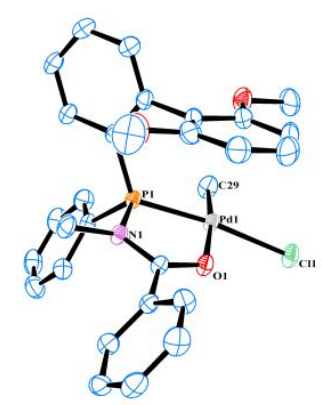

Molecular structures of catalysts Pd2. Hydrogen atoms were omitted for clarity.

\begin{tabular}{|c|c|}
\hline Formula & C31H33Cl5NO3PPd \\
\hline Formula weight & 782.20 \\
\hline Temperature $[\mathrm{K}]$ & $298(2)$ \\
\hline$\lambda(\mathrm{Mo}-\mathrm{K} \alpha)[\AA]$ & 0.71073 \\
\hline Crystal system & Triclinic \\
\hline Space group & $\mathrm{P}-1$ \\
\hline $\mathrm{a}[\AA]$ & $11.6706(7)$ \\
\hline $\mathrm{b}[\AA]$ & $12.1971(8)$ \\
\hline $\mathrm{c}[\AA]$ & $12.6599(9)$ \\
\hline$\alpha\left[^{\circ}\right]$ & $74.8850(10)$ \\
\hline$\beta\left[^{\circ}\right]$ & $85.413(2)$ \\
\hline$\gamma\left[^{\circ}\right]$ & $81.427(2)$ \\
\hline Volume $\left[\AA^{3}\right]$ & $1718.7(2)$ \\
\hline $\mathrm{Z}$ & 2 \\
\hline $\mathrm{D}($ calc $)\left[\mathrm{g} \cdot \mathrm{cm}^{-3}\right]$ & 1.511 \\
\hline$\mu\left[\mathrm{mm}^{-1}\right]$ & 1.007 \\
\hline $\mathrm{F}(000)$ & 792 \\
\hline$\theta \min -\max \left({ }^{\circ}\right)$ & $2.925-27.643$ \\
\hline$h$ & $-13 \rightarrow 13$ \\
\hline$k$ & $-14 \rightarrow 11$ \\
\hline$l$ & $-15 \rightarrow 15$ \\
\hline Reflections collected & 8693 \\
\hline Reflections unique & 5967 \\
\hline $\mathrm{R}$ (int) & 0.0340 \\
\hline Data / restraints / parameters & $5697 / 0 / 384$ \\
\hline Final $R$ indices $[I>2 \sigma(I)]$ & $\begin{array}{l}\mathrm{R}_{1}=0.0467 \\
\mathrm{wR}_{2}=0.1253\end{array}$ \\
\hline $\mathrm{R}$ indices (all data) & $\begin{array}{l}\mathrm{R}_{1}=0.0571 \\
\mathrm{wR}_{2}=0.1333\end{array}$ \\
\hline GOF on $\mathrm{F}^{2}$ & 1.059 \\
\hline
\end{tabular}




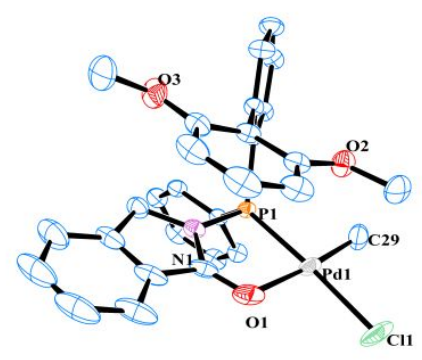

Molecular structures of catalysts Pd9. Hydrogen atoms were omitted for clarity.

\begin{tabular}{|c|c|}
\hline Formula & C30.50 H30 Cl4 N O3 P Pd \\
\hline Formula weight & 737.73 \\
\hline Temperature[K] & 293(2) \\
\hline$\lambda(\mathrm{Mo}-\mathrm{K} \alpha)[\AA]$ & 1.54178 \\
\hline Crystal system & Triclinic \\
\hline Space group & $P-1$ \\
\hline $\mathrm{a}[\AA \AA]$ & $10.8744(7)$ \\
\hline $\mathrm{b}[\AA]$ & $11.1244(7)$ \\
\hline$c[\AA ̊]$ & $15.8795(11)$ \\
\hline$\alpha\left[^{\circ}\right]$ & $71.869(6)$ \\
\hline$\beta\left[^{\circ}\right]$ & $73.683(6)$ \\
\hline$\gamma\left[^{\circ}\right]$ & $63.086(7)$ \\
\hline Volume $\left[\AA^{3}\right]$ & $1605.45(18)$ \\
\hline $\mathrm{Z}$ & 2 \\
\hline $\mathrm{D}(\mathrm{calc})\left[\mathrm{g} \cdot \mathrm{cm}^{-3}\right]$ & 1.526 \\
\hline$\mu\left[\mathrm{mm}^{-1}\right]$ & 8.457 \\
\hline $\mathrm{F}(000)$ & 746 \\
\hline$\theta$ min-max $\left({ }^{\circ}\right)$ & $4.6240-71.9670$ \\
\hline$h$ & $-12 \rightarrow 10$ \\
\hline$k$ & $-13 \rightarrow 8$ \\
\hline$l$ & $-18 \rightarrow 18$ \\
\hline Reflections collected & 10012 \\
\hline Reflections unique & 5600 \\
\hline $\mathrm{R}$ (int) & 0.0385 \\
\hline Data / restraints / parameters & $5600 / 6 / 382$ \\
\hline Final R indices $[I>2 \sigma(I)]$ & $\begin{array}{l}\mathrm{R}_{1}=0.0532 \\
\mathrm{wR}_{2}=0.1366\end{array}$ \\
\hline $\mathrm{R}$ indices (all data) & $\begin{array}{l}\mathrm{R}_{1}=0.0644 \\
\mathrm{wR}_{2}=0.1478\end{array}$ \\
\hline GOF on $\mathrm{F}^{2}$ & 1.044 \\
\hline
\end{tabular}




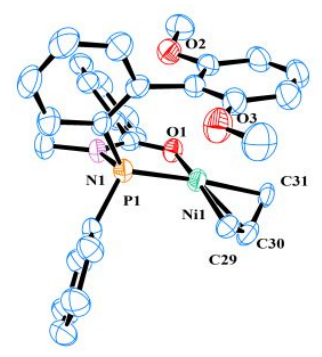

Molecular structures of catalysts Ni2. Hydrogen atoms and the BArF4 groups were omitted for clarity.

\begin{tabular}{|c|c|}
\hline Formula & C63H43BF24NNiO3P \\
\hline Formula weight & 1418.47 \\
\hline Temperature $[\mathrm{K}]$ & 298(2) \\
\hline$\lambda(\mathrm{Mo}-\mathrm{K} \alpha)[\AA]$ & 0.71073 \\
\hline Crystal system & Triclinic \\
\hline Space group & P-1 \\
\hline $\mathrm{a}[\AA]$ & $13.3460(12)$ \\
\hline $\mathrm{b}[\AA]$ & $14.9860(13)$ \\
\hline $\mathrm{c}[\AA]$ & $16.7120(14)$ \\
\hline$\alpha\left[^{\circ}\right]$ & $88.653(2)$ \\
\hline$\beta\left[^{\circ}\right]$ & $80.9610(10)$ \\
\hline$\gamma\left[^{\circ}\right]$ & $74.8670(10)$ \\
\hline Volume $\left[\AA^{3}\right]$ & $3185.9(5)$ \\
\hline $\mathrm{Z}$ & 2 \\
\hline $\mathrm{D}($ calc $)\left[\mathrm{g} \cdot \mathrm{cm}^{-3}\right]$ & 1.479 \\
\hline$\mu\left[\mathrm{mm}^{-1}\right]$ & 0.445 \\
\hline $\mathrm{F}(000)$ & 1432 \\
\hline$\theta \min -\max \left({ }^{\circ}\right)$ & $2.469-21.633$ \\
\hline$h$ & $-15 \rightarrow 15$ \\
\hline$k$ & $-16 \rightarrow 17$ \\
\hline$l$ & $-14 \rightarrow 19$ \\
\hline Reflections collected & 16193 \\
\hline Reflections unique & 11060 \\
\hline $\mathrm{R}$ (int) & 0.0243 \\
\hline Data / restraints / parameters & 11060 / 0 / 1099 \\
\hline Final $R$ indices $[\mathrm{I}>2 \sigma(\mathrm{I})]$ & $\begin{array}{l}\mathrm{R}_{1}=0.0468 \\
\mathrm{wR}_{2}=0.0886\end{array}$ \\
\hline $\mathrm{R}$ indices (all data) & $\begin{array}{l}\mathrm{R}_{1}=0.0994 \\
\mathrm{wR}_{2}=0.1009\end{array}$ \\
\hline GOF on $\mathrm{F}^{2}$ & 1.004 \\
\hline
\end{tabular}




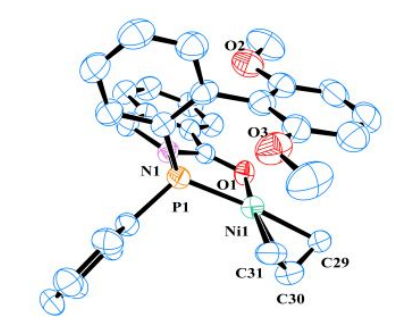

Molecular structures of catalysts Ni9. Hydrogen atoms and the BArF4 groups were omitted for clarity..

\begin{tabular}{|c|c|}
\hline Formula & C63 H41 B F24 N Ni O3 P \\
\hline Formula weight & 1416.46 \\
\hline Temperature[K] & $298(2)$ \\
\hline$\lambda(\mathrm{Mo}-\mathrm{K} \alpha)[\AA]$ & 0.71073 \\
\hline Crystal system & Triclinic \\
\hline Space group & $\mathrm{P}-1$ \\
\hline $\mathrm{a}[\AA]$ & $13.4544(13)$ \\
\hline $\mathrm{b}[\AA]$ & $14.0503(14)$ \\
\hline $\mathrm{c}[\AA]$ & $17.7828(16)$ \\
\hline$\alpha\left[^{\circ}\right]$ & $94.7530(10)$ \\
\hline$\beta\left[^{\circ}\right]$ & $107.799(2)$ \\
\hline$\gamma\left[^{\circ}\right]$ & $93.9010(10)$ \\
\hline Volume $\left[\AA^{3}\right]$ & $3174.2(5)$ \\
\hline Z & 2 \\
\hline $\mathrm{D}($ calc $)\left[\mathrm{g} \cdot \mathrm{cm}^{-3}\right]$ & 1.482 \\
\hline$\mu\left[\mathrm{mm}^{-1}\right]$ & 0.447 \\
\hline $\mathrm{F}(000)$ & 1428 \\
\hline$\theta \min -\max \left({ }^{\circ}\right)$ & $2.269-19.901$ \\
\hline$h$ & $-15 \rightarrow 15$ \\
\hline$k$ & $-16 \rightarrow 14$ \\
\hline$l$ & $-21 \rightarrow 20$ \\
\hline Reflections collected & 16210 \\
\hline Reflections unique & 11021 \\
\hline $\mathrm{R}$ (int) & 0.0378 \\
\hline Data / restraints / parameters & $11021 / 0 / 1098$ \\
\hline \multirow{2}{*}{ Final $R$ indices $[\mathrm{I}>2 \sigma(\mathrm{I})]$} & $\mathrm{R}_{1}=0.0560$ \\
\hline & $\mathrm{wR}_{2}=0.1272$ \\
\hline \multirow{2}{*}{$\mathrm{R}$ indices (all data) } & $\mathrm{R}_{1}=0.1271$ \\
\hline & $\mathrm{wR}_{2}=0.1468$ \\
\hline GOF on $\mathrm{F}^{2}$ & 0.819 \\
\hline
\end{tabular}




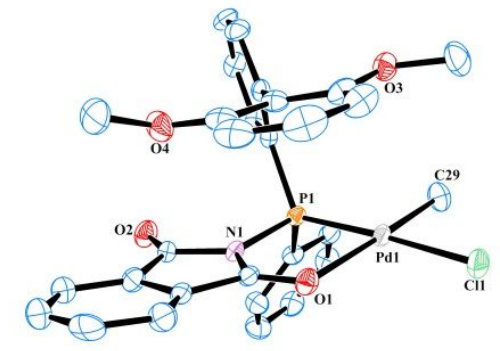

Molecular structures of catalysts Pd10. Hydrogen atoms were omitted for clarity.

\begin{tabular}{|c|c|}
\hline Formula & C29 H25 Cl N O4 P Pd \\
\hline Formula weight & 624.32 \\
\hline Temperature[K] & 293(2) \\
\hline$\lambda(\mathrm{Mo}-\mathrm{K} \alpha)[\AA]$ & 1.54178 \\
\hline Crystal system & Monoclinic \\
\hline Space group & $\mathrm{P} 2(1) / \mathrm{n}$ \\
\hline $\mathrm{a}[\AA]$ & $12.2388(12)$ \\
\hline $\mathrm{b}[\AA]$ & $18.0902(15)$ \\
\hline$c[\AA]$ & $12.4222(10)$ \\
\hline$\alpha\left[^{\circ}\right]$ & 90.00 \\
\hline$\beta\left[^{\circ}\right]$ & $109.235(10)$ \\
\hline$\gamma\left[^{\circ}\right]$ & 90.00 \\
\hline Volume $\left[\AA^{3}\right]$ & $2596.8(4)$ \\
\hline $\mathrm{Z}$ & 4 \\
\hline $\mathrm{D}(\mathrm{calc})\left[\mathrm{g} \cdot \mathrm{cm}^{-3}\right]$ & 1.597 \\
\hline$\mu\left[\mathrm{mm}^{-1}\right]$ & 7.599 \\
\hline $\mathrm{F}(000)$ & 1264 \\
\hline$\theta$ min-max $\left({ }^{\circ}\right)$ & $4.4700-71.3080$ \\
\hline$h$ & $-14 \rightarrow 10$ \\
\hline$k$ & $-21 \rightarrow 21$ \\
\hline$l$ & $-9 \rightarrow 14$ \\
\hline Reflections collected & 9557 \\
\hline Reflections unique & 4516 \\
\hline $\mathrm{R}($ int $)$ & 0.0714 \\
\hline Data / restraints / parameters & $4516 / 0 / 337$ \\
\hline Final $\mathrm{R}$ indices $[\mathrm{I}>2 \sigma(\mathrm{I})]$ & $\begin{array}{l}\mathrm{R}_{1}=0.0570 \\
\mathrm{wR}_{2}=0.1237\end{array}$ \\
\hline $\mathrm{R}$ indices (all data) & $\begin{array}{l}\mathrm{R}_{1}=0.0872 \\
\mathrm{wR}_{2}=0.1429\end{array}$ \\
\hline GOF on $\mathrm{F}^{2}$ & 1.025 \\
\hline
\end{tabular}

